Pacific Northwest National Laboratory

Operated by Battelle for the

U. Department of Energy

\title{
Denitration of High Nitrate Salts Using Reductants
}

\author{
H. D. Smith \\ E. O. Jones \\ A. J. Schmidt \\ A. H. Zacher \\ M. D. Brown \\ M. R. Elmore \\ S. R. Gano
}

April 1999

\section{RECEIVED \\ MAY 251999 \\ OSTI}

Prepared for the U.S. Department of Energy under Contract DE-AC06-76RLO 1830 


\title{
DISCLAIMER
}

This report was prepared as an account of work sponsored by an agency of the United States Government. Neither the United States Government nor any agency thereof, nor Battelle Memorial Institute, nor any of their employees, makes any warranty, express or implied, or assumes any legal liability or responsibility for the accuracy, completeness, or usefulness of any information, apparatus, product, or process disclosed, or represents that its use would not infringe privately owned rights. Reference herein to any specific commercial product, process, or service by trade name, trademark, manufacturer, or otherwise does not necessarily constitute or imply its endorsement, recommendation, or favoring by the United States Government or any agency thereof, or Battelle Memorial Institute. The views and opinions of authors expressed herein do not necessarily state or reflect those of the United States Government or any agency thereof.

\author{
PACIFIC NORTHWEST NATIONAL LABORATORY \\ operated by \\ BATTELLE \\ for the \\ UNITED STATES DEPARTMENT OF ENERGY \\ under Contract DE-AC06-76RLO 1830
}

Printed in the United States of America

Available to DOE and DOE contractors from the

Office of Scientific and Technical Information, P.O. Box 62, Oak Ridge, TN 37831;

prices available from (615) $576-8401$.

Available to the public from the National Technical Information Service, U.S. Department of Commerce, 5285 Port Royal Rd., Springfield, VA 22161 


\section{DISCLAIMER}

Portions of this document may be illegible in electronic image products. Images are produced from the best available original document. 
PNNL-12144

\section{Denitration of High Nitrate Salts Using Reductants}

H. D. Smith

E. O. Jones

A. J. Schmidt

A. H. Zacher

M. D. Brown

M. R. Elmore

S. R. Gano

April 1999

Prepared for

the U.S. Department of Energy

under Contract DE-AC06-76RLO 1830

Funded by the Office of Science and Technology, within the DOE Office of Environmental

Management, under the Tank Focus Area

Pacific Northwest National Laboratory

Richland, Washington 99352 



\section{Summary}

This report describes work conducted by Pacific Northwest National Laboratory (PNNL), in conjunction with Idaho National Engineering and Environmental Laboratory (INEEL), to remove nitrates in simulated low-activity waste (LAW). The major objective of this work was to provide data for identifying and demonstrating a technically viable and cost-effective approach to condition LAW for immobilization (grout).

The simulated LAW used for this testing represents LAW to be derived from separating high-level sodium-bearing waste (SBW) at the Idaho Chemical Processing Plant (ICPP). The actual LAW stream will be acidic, high in nitrates, and high in alkali metals, all of which are detrimental to LAW grout formation and performance. Several candidate approaches have been identified, ranging from simple evaporation to thermal-chemical denitration as preconditioning steps to the grouting process.

Through testing and engineering studies, PNNL has evaluated an approach that consists of distillation followed by low-temperature thermochemical denitration with a reductant addition. This process scheme was selected to minimize volatilization of radionuclides and hazardous constituents, and to convert most of the nitrate in the waste to at least $50 \%$ nitrogen gas instead of $\mathrm{NO}_{\mathrm{x}}$ during $\mathrm{LAW}$ calcination, while still producing a groutable product. INEEL is investigating high-temperature calcination for the LAW, a process already selected by INEEL for calcining high-level wastes.

Previous testing by PNNL and others has successfully demonstrated thermochemical denitration of low-level and high-level waste simulants with carbon-based reductant compounds such as carbohydrates (e.g., sugar). This report describes the work conducted by PNNL during FY 1997 and FY 1998 to evaluate the applicability of this technology to denitrate LAW. The LAW stream (on a dry weight basis) is approximately $80 \%$ nitrate. The denitration reaction for the nitrate and carbohydrate proceeds as follows:

$$
1.25 \mathrm{C}_{\mathrm{n}} \mathrm{H}_{2 \mathrm{n}} \mathrm{O}_{\mathrm{n}}+\mathrm{nNaNO} \mathrm{NaNO}_{3} \longrightarrow(0.5 \mathrm{n}) \mathrm{N}_{2} \uparrow+(0.75 \mathrm{n}) \mathrm{CO}_{2} \uparrow+(1.25 \mathrm{n}) \mathrm{H}_{2} \mathrm{O} \uparrow+(0.5 \mathrm{n}) \mathrm{Na}_{2} \mathrm{CO}_{3}
$$

There are several important advantages of the approach evaluated here over more conventional thermal denitration techniques:

- Higher levels of denitration can be achieved. While thermal denitration at $700^{\circ} \mathrm{C}$ for $8 \mathrm{hr}$ has shown denitration efficiencies of $60 \%$ to $75 \%$ with the LAW, with reductant addition, greater than $90 \%$ denitration was achieved at less than $300^{\circ} \mathrm{C}$ in $20 \mathrm{~min}$.

- Approximately $50 \%$ to $70 \%$ of the nitrates destroyed are converted to $\mathrm{N}_{2}$, with the remaining fraction being converted to $\mathrm{N}_{2} \mathrm{O}$ and $\mathrm{NO}_{\mathrm{x}}$. During conventional thermal denitration by high-temperature calcination, materials are typically heated to a temperature $\left(600^{\circ} \mathrm{C}\right.$ to $\left.700^{\circ} \mathrm{C}\right)$ that causes the majority of nitrates to decompose to nitrogen oxides (principally $\mathrm{NO}_{\mathrm{x}}$ ) with a minimum generation of $\mathrm{N}_{2}$. 
With the addition of a simple reductant, the cost to prevent the formation of $\mathrm{NO}_{\mathrm{x}}$ is estimated to be only a small fraction of the costs normally incurred for abatement of $\mathrm{NO}_{\mathbf{x}}$ from radioactive waste processing.

- More conventional equipment and materials of construction can be used, since denitration is effective at lower temperatures.

The activities conducted by PNNL for this project involved laboratory and bench-scale testing to provide analytical and process data to identify denitration process conditions, and to evaluate and recommend candidate calcination strategies and equipment. The optimum flow scheme was determined to be distillation to remove reusable nitric acid, followed by thermochemical reduction using a groutcompatible diluent. Distillation tests were conducted to remove and concentrate nitric acid from the LAW before thermochemical denitration testing was performed. Laboratory scoping tests were designed to evaluate the effects of reductant and inert types and addition ratios on the reaction chemistry. Reaction calorimetry testing was conducted to quantify the nitrate/reductant reaction energies. Pot calcination and rotary calciner tests were conducted to examine the physical behavior and offgas characteristics associated with thermochemical denitration of LAW. Finally, an engineering evaluation was performed to examine calcination systems and industrial practices for calcining nitrate-bearing steams in the presence of reductants. The major conclusions and key observations from the testing and evaluations of low-temperature denitration are summarized below.

A number of approaches for deploying the thermochemical denitration technology were evaluated. PNNL's recommended approach was largely based on the characteristics and composition of the LAW. Since approximately half of the nitrate associated with the LAW is in the form of dilute nitric acid ( $\sim 0.5 \mathrm{M} \mathrm{HNO}_{3}$ ), distillation was included as a pretreatment step to decrease the total nitrate level before thermochemical denitration. During the laboratory-scale distillation testing conducted by PNNL, over $95 \%$ of the nitric acid was recovered at a concentration of about $6.5 \mathrm{M}$. This recovered acid would be available for reuse in the acid calcine dissolution process planned at ICPP. The bottoms from the distillation, which were approximately $70 \%$ (dry weight) nitrate in the tests, can be mixed with a reductant and an inert grout additive material and then be thermochemically denitrated in the calciner. Since the inert material selected could replace a grout additive, it is not expected to increase the final volume of the grouted, denitrified SBW. For the LAW simulant (high nitrate), inert materials can be added to dilute the denitration reaction energy. In other streams containing less than $30 \%$ nitrate, a diluent may not be needed.

\section{Distillation Testing}

A series of batch distillation experiments were performed at 125,500 , and $760 \mathrm{mmHg}$ using LAW simulant to determine:

- acidic nitrate removal

- $\mathrm{NO}_{\mathrm{x}}$ behavior at different temperatures

- mercury volatility 
- crystal behavior and inception point

- boiling point behavior at different vacuums.

Distillation removed approximately $50 \%$ of the nitrate as nitric acid in the LAW simulant and reduced the total amount to be processed further by $80 \%$. In the batch distillation tests, over $95 \%$ of the nitric acid was recovered at a concentration of about $6.5 \mathrm{M}$. The recovered acid would be available for reuse in the acid calcine dissolution process. The residual crystals and slurry from the distillation were easily redissolved in water.

As expected, the initial boiling points were lower for the lower vacuum, but the final distillation temperatures were similar at $118^{\circ} \mathrm{C}$ to $120^{\circ} \mathrm{C}$ due to the lack of volatile water and acid at the end of the batch distillation. Therefore, there is little advantage in operating at a vacuum with respect to operating temperatures. In addition, very little $\mathrm{NO}_{\mathrm{x}}$ formed at any condition, again eliminating the need for vacuum operation. The acidic nitrate removed varied with temperature, depending on the final temperature.

\section{Thermochemical Denitration Scoping Tests}

Scoping tests were performed to obtain laboratory experience on the rate of reaction between the LAW and reducing materials, such as sugar and glycolic acid. In general, the reaction rates were very fast once the reaction started, accomplished by heating the mixtures to between $200^{\circ} \mathrm{C}$ and $300^{\circ} \mathrm{C}$. The reaction rate was observed to be retarded by mixing a finely divided inert material, such as Micro-Cel $\mathrm{E}$ (a synthetic calciner silicate), with the reaction mixture.

\section{Reaction Calorimetry Testing-Thermochemical Denitration Reactions}

Reaction calorimetry tests were completed in a C 80 II Calvet calorimeter to quantify reaction onset temperatures and the rates and energies of reactions. The tests were performed with the LAW bottoms (from distillation), with two different reductants and two different inert additives (Micro-Cel E and flyash). The reductants, sugar (sucrose) and glycolic acid, were tested at different stoichiometric ratios of reductant to simulant.

In general, for most of the reaction calorimetry tests, two exothermic reactions occurred at around $100^{\circ} \mathrm{C}$ and $250^{\circ} \mathrm{C}$, releasing a total of about 1000 to $1400 \mathrm{~J} / \mathrm{g}$ at a controllable rate. The experimental data indicate that the nitrate/reductant reaction rates and energies can be safely managed using commercially available equipment. [As a point of reference, the energy content of coal is 30,000 to $35,000 \mathrm{~J} / \mathrm{g}$.] However, the temperature ramp profile in a commercial calciner will be much more compressed than the $0.1^{\circ} \mathrm{C} / \mathrm{min}$ used in the reaction calorimeter. Consequently, the multiple exotherms would likely be compressed into a single event. Testing with a continuous prototypical calciner system will be necessary to assess the reaction behaviors in a commercial system. 


\section{Pot Calcination-Laboratory-Scale Thermochemical Denitration Testing}

Pot calciner tests were performed to establish the offgas chemistry that was being generated by the reactions between the LAW bottoms and the organic reductants. Mixtures containing the inert additive Micro-Cel E were used to slow the reaction, so the reaction gases could be sampled and analyzed. Tests run with sub-stoichiometric mixtures (no residual organic carbon) using sugar or glycolic acid produced mixtures of nitrogen and nitrogen oxide gases consistent with the mixture composition.

\section{Bench-Scale Rotary Calciner Thermochemical Denitration Testing}

A series of denitration batch tests were performed with a bench-scale rotary calciner using LAW bottoms as the feedstock. In the testing, diluents such as Micro-Cel $\mathrm{E}$ and flyash were tested; reductants such as sugar and glycolic acid were examined; and both air and argon were tested as a cover gas on the calciner. Eight tests were performed with 3.5 to $30 \mathrm{~g}$ of nitrate-bearing feedstock of various dilutions. Most of the products were measured for final nitrate and total organic carbon concentrations. Process temperatures and pressures were recorded during each test. The product offgas was analyzed by gas chromatograph and/or $\mathrm{NO}_{\mathrm{x}}$ analyzer, depending on the run.

Results from the bench-scale testing showed a $90 \%$ to $99.8 \%$ nitrate reduction at temperatures above $250^{\circ} \mathrm{C}$, with either reductant or cover gas. However, the reductant and LAW must be intimately mixed to achieve this high reduction rate. Some diluents can greatly affect the ignition temperature of the reaction. In all cases, the reacted product resulted in an easily handled powder.

Because a uniform bed temperature is created in the batch calciner, the nitrate/reductant reaction occurs through the entire bed quickly, releasing significant quantities of offgas over a short period of time. In a continuously fed calciner, a temperature gradient would be established along the length of the calciner, and the reaction zone would be confined to a narrow band, producing a more constant volume and composition of offgas.

\section{Engineering Studies}

A comprehensive survey (over 50 companies worldwide) was made of mainstream chemical processing industries (e.g., chemical, petrochemical, mineral, waste processing). The most relevant companies were then reviewed in detail, and the information integrated into the engineering evaluation. The study failed to discover any substantiative parallel large-scale processing examples similar in reaction chemistry and processing attributes to the proposed thermochemical denitration process for the INEEL LAW.

Two developmental-stage processes, however, COGEMA's rotary kiln denitration of radioactive waste and PNNL's Glycine Nitrate process for production of specialty ceramics, were found to possess similar reaction chemistry and should be investigated further. Both processes have been shown to safely operate for extended periods at pilot scale or larger. Both could be tested in the rotary kiln pilot plant 
available at PNNL. While the operating details of COGEMA's process are described as proprietary, the purported reaction chemistry and an assertion that a process is currently operating in France dictate that further inquiries should still be made.

After these two processes, both the INEEL baseline+sugar flowsheet and a flowsheet based on U.S. Bureau of Mines briquette research appear to meet the system requirements and environmental issues better than high-temperature thermal systems. Their development should be carefully weighed against the substantial costs and operating issues surrounding selective catalytic reduction of $\mathrm{NO}_{\mathrm{x}}$ required of hightemperature destruction technologies.

The various flowsheets and criteria evaluated, and the individual rankings assigned, are presented below.

\begin{tabular}{|l|l|l|l|l|l|l|l|}
\hline \multicolumn{1}{|c|}{ Criteria } & Baseline & $\begin{array}{c}\text { Baseline } \\
\text { Sugar } \\
\text { Addition }\end{array}$ & $\begin{array}{c}\text { High-Temp. } \\
\text { Drying } \\
\text { (no sugar) }\end{array}$ & $\begin{array}{c}\text { COGEMA } \\
\text { Direct Feed } \\
\text { Rotary Kin } \\
\text { (w/ sugar) }\end{array}$ & $\begin{array}{c}\text { PNNL } \\
\text { Glycine } \\
\text { Nitrate }\end{array}$ & $\begin{array}{c}\text { Rocketdyne } \\
\text { Fast } \\
\text { Calciner }\end{array}$ & $\begin{array}{c}\text { Bureau of } \\
\text { Mines } \\
\text { Briquetting }\end{array}$ \\
\hline $\begin{array}{l}\text { Operating } \\
\text { Suitability }\end{array}$ & High & High & Medium & High & High & High & High \\
\hline $\begin{array}{l}\text { Technical } \\
\text { Availability }\end{array}$ & High & High & High & High & Medium & Low & Medium \\
\hline $\begin{array}{l}\text { System } \\
\text { Operability }\end{array}$ & Medium & Medium & Medium & High & Medium & Medium & Medium \\
\hline $\begin{array}{l}\text { Facility/System } \\
\text { Integration }\end{array}$ & High & High & Medium & Medium & Medium & Low & Medium \\
\hline $\begin{array}{l}\text { Safety \& } \\
\text { Environmental }\end{array}$ & Medium & Medium & Medium & High & Medium & Medium & High \\
\hline $\begin{array}{l}\text { Equipment } \\
\text { Design Issues }\end{array}$ & High & High & Medium & High & Medium & Low & Medium \\
\hline
\end{tabular}

\section{Applicability to Other Waste Streams}

High nitrate waste streams are a common problem within the U.S. Department of Energy complex. The technology discussed in this report can be tailored to address those waste streams, in modes ranging from a large fixed installation to a small mobile unit. 



\section{Acknowledgments}

This work was prepared with the support of the following contributors:

$\begin{array}{ll}\text { Headquarters: } & \text { Office of Science and Technology } \\ \text { David Geiser }\end{array}$

Focus Area/Program: Tank Focus Area

Terri L. Stewart, PNNL

Operations Office: Richland Operations Office

Science and Technology Programs Division

John P. Neath, Technical Program Officer

Contractor: $\quad$ Pacific Northwest National Laboratory

Environmental Science and Technology

Environmental Technology Division

Rod K. Quinn, Manager 



\section{Contents}

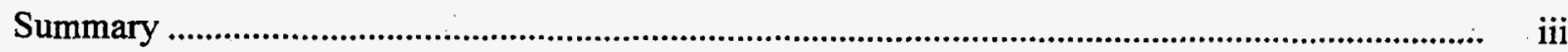

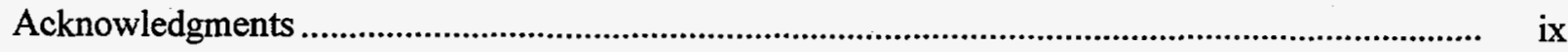

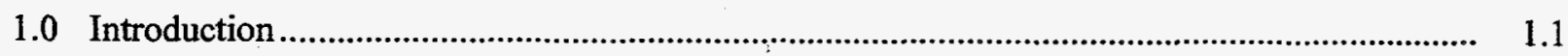

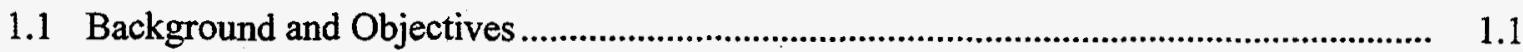

1.2 Thermochemical Denitration by Reductant Addition-Technology Description ............ 1.2

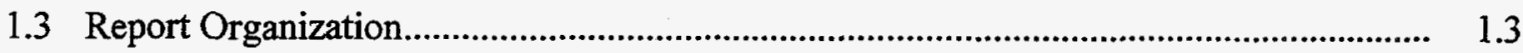

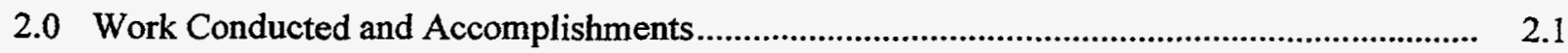

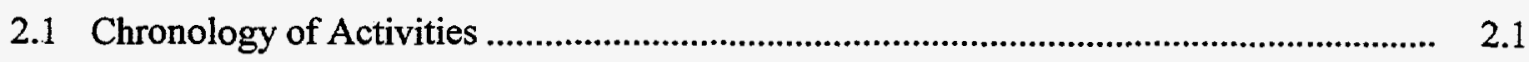

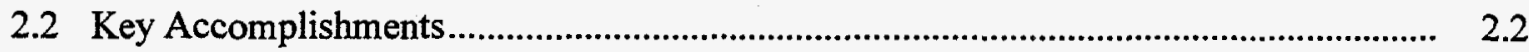

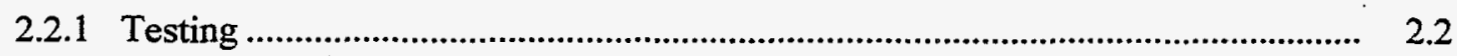

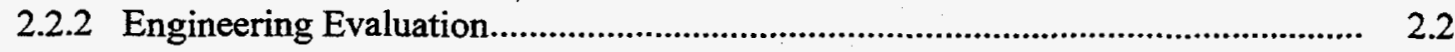

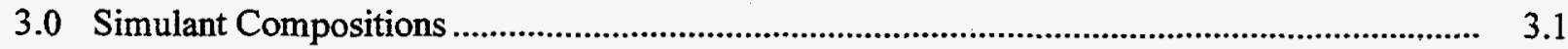

4.0 LAW Preconditioning-Removal of Nitric Acid by Distillation ......................................... 4.1

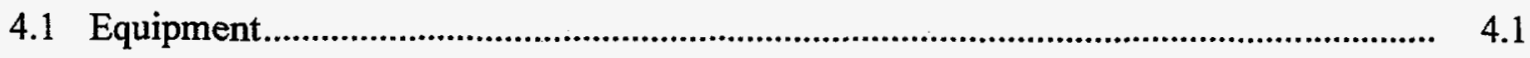

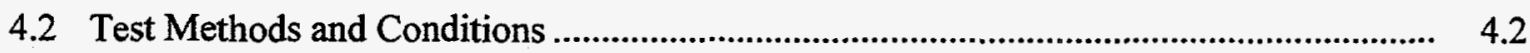

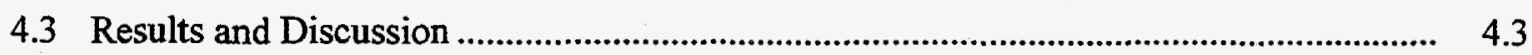

5.0 . Denitration Testing Via Reductant Addition ........................................................... 5.1

5.1 Chemistry of Reductant Addition ....................................................................... 5.1

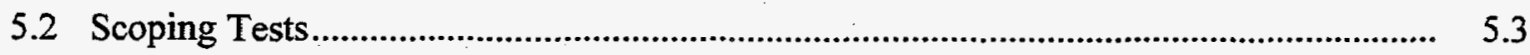

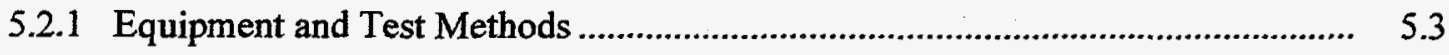

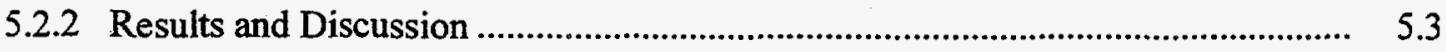


5.3 Reaction Calorimetry Testing.

5.3.1 Equipment-Calvet Calorimeter ......................................................................... 5.5

5.3.2 Test Methods and Conditions ........................................................................ 5.6

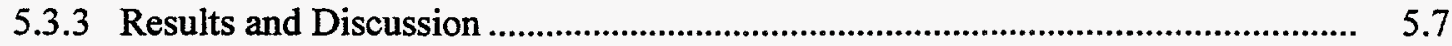

5.4 Pot Calciner (With Offgas Analysis) …................................................................ 5.9

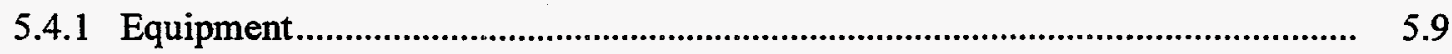

5.4.2 Test Methods and Conditions ......................................................................... 5.10

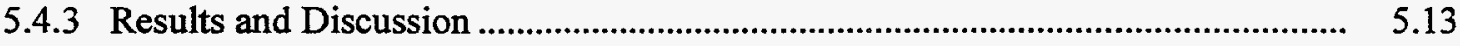

5.5 Bench-Scale Rotary Calciner ..................................................................................... $\quad 5.15$

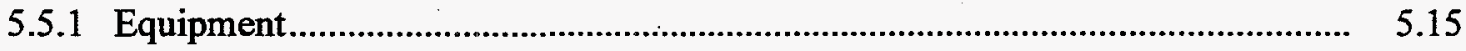

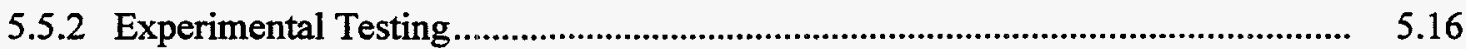

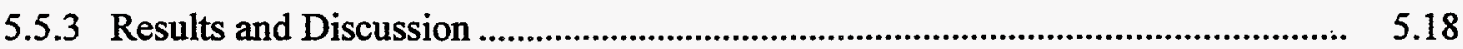

6.0 Engineering Evaluation and Alternative Flowsheet Development ...................................... 6.1

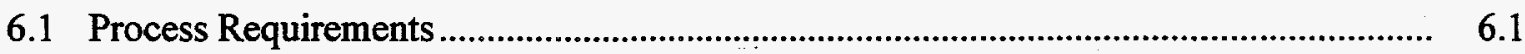

6.1.1 Residual Nitrate in Product............................................................................... 6.1

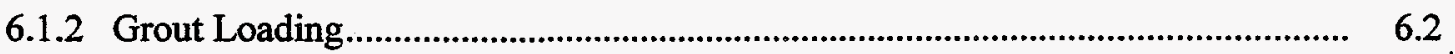

6.1.3 Waste Preparation/Handling ................................................................................. 6.2

6.1.4 Reductant Chemistry and Addition................................................................ 6.3

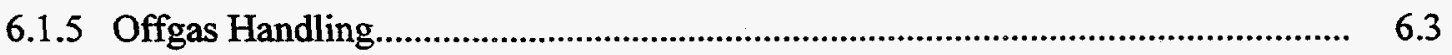

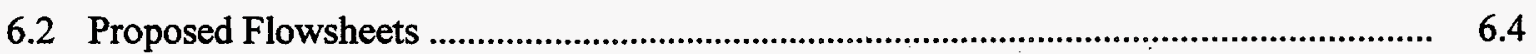

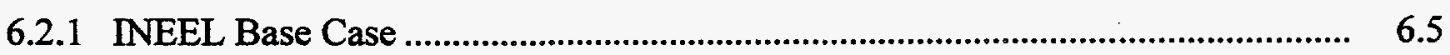

6.2.2 INEEL Baseline+Sugar Flowsheet ................................................................... 6.8 
6.2.3 INEEL High-Temperature Drying/Rotary Kiln

6.2.4 COGEMA Direct Injection Rotary Kiln

6.2.5 PNNL Glycine Denitration Flowsheet

6.2.6 Bureau of Mines Briquette Flowsheet

6.3 Engineering-Scale Equipment

6.3.1 Pretreatment Options

6.3.2 Denitration Reactor Options

\subsubsection{Offgas Treatment}

6.4 Engineering Recommendations

7.0 References

8.0 Supporting Documents.

Appendix A - Review of Denitration Chemistry

A. 1

Appendix B - Annotated Literature Survey

B.1

Appendix C - Run Observations and Data from Rotary Calciner Tests

C. 1

Appendix D - Bibliography

D.1

Appendix E - Calorimetry Plots from Reaction Calorimeter Testing.

E.1 


\section{Figures}

4.1 Apparatus for Vacuum Distillation of Simulated LAW .....................................................

4.2 Temperature and Concentration Profiles at $125 \mathrm{mmHg}$ Data ............................................ 4.4

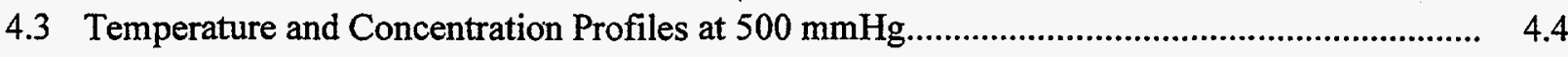

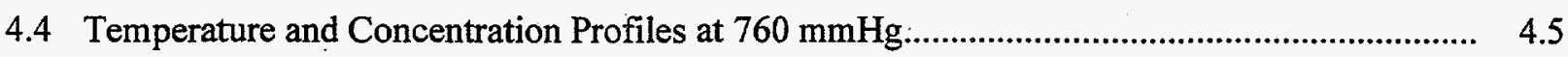

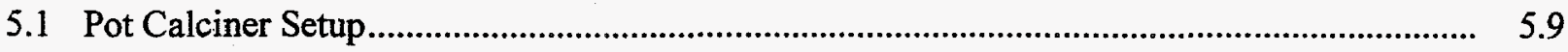

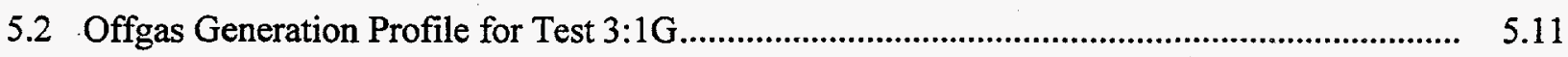

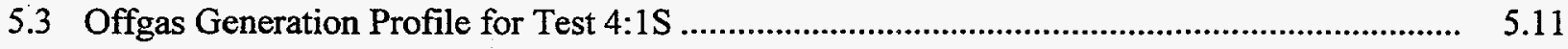

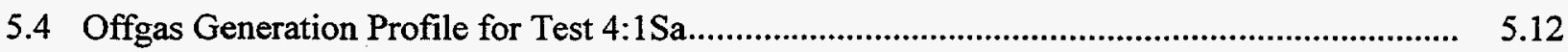

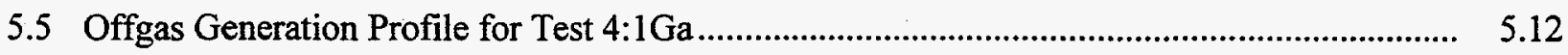

5.6 Bench-scale Rotary Calciner with Quartz Reactor ......................................................

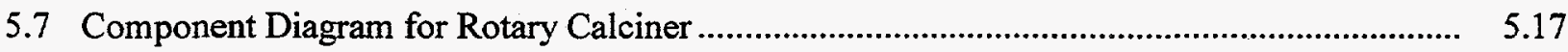

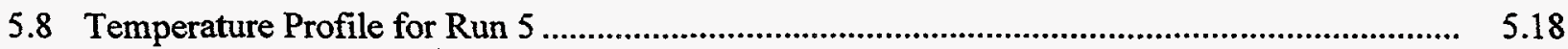

5.9 Temperature and Gas Flow Profile for Run 4 ............................................................ 5.22

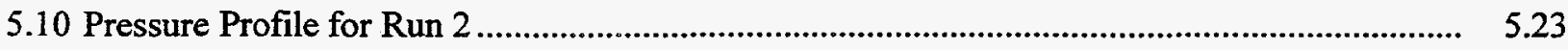

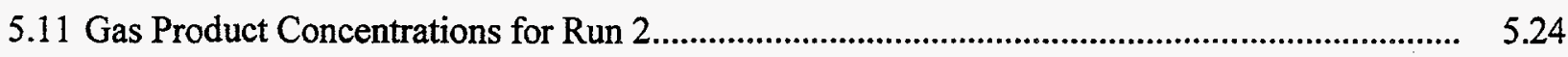

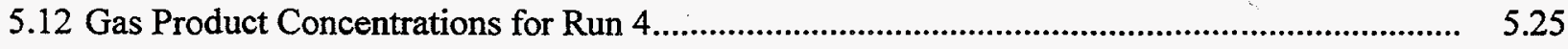

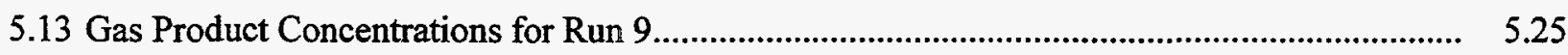

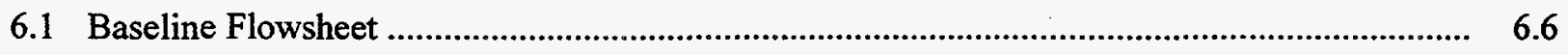

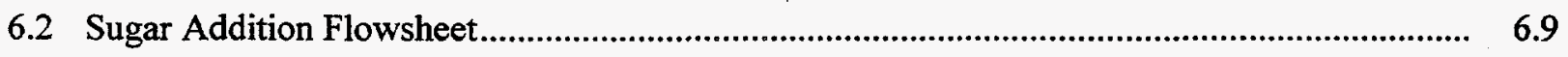

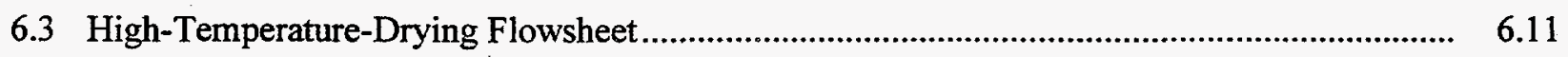


6.4 COGEMA Rotary Kiln Flowsheet

6.13

6.5 PNNL Glycine Nitrate Flowsheet.

6.15

6.6 Bureau of Mines Briquette Flowsheet

6.17

6.7 Glycine Nitrate Process Pilot Plant

6.22 


\section{Tables}

3.1 LAW (derived from SBW) Simulant Composition.

3.2 Inert Materials Used in the TFA-INEEL Denitration Studies and Potential Use with Other Waste Systems

4.1 Summary of Distillation Tests

4.2 Analyses of LAW Simulant, Distillation Condensates, and Final Still Bottoms at $125 \mathrm{mmHg}$.

5.1 Specific Energy of $\mathrm{NaNO}_{3}$-Organic Reaction.

5.2 Summary of Boildown Scoping Tests with LAW and Reductants

5.3 Summary of Reaction Calorimetry Runs with LAW Bottoms 5.8

5.4 Initial Test Conditions.

5.5 Exotherm Initiation Temperatures and Peak Observed Temperatures.

5.6 Peak Sweep Gas Concentrations of Offgas from Denitration Reactions

5.7 Summary of Feed Conditions for Rotary Calciner Runs with LAW Evaporator Bottoms Simulant.

5.8 Summary of PNNL Rotary Calciner Runs with LAW Bottoms

5.9 Gas Product Summary for Selected Tests 


\subsection{Introduction}

The testing described in this report was conducted by Pacific Northwest National Laboratory (PNNL) to evaluate a distillation/thermochemical denitration processing scheme for preconditioning a low-activity waste (LAW), generated at the Idaho Chemical Processing Plant (ICPP), to address requirements for grout disposal. To be suitable for disposal, the final LAW waste form must comply with established grout performance specifications while achieving reasonable waste loadings in the grout. Destruction of nitrates in the wastes is seen as a significant feature of a treatment process that will enable these wastes to meet the performance specifications. Processing must also meet air and water quality requirements for release of offgases and liquids.

\subsection{Background and Objectives}

The work described here focused on LAW resulting from a proposed separation process for sodiumbearing waste (SBW) at ICPP, which will be acidic, high in nitrates, and high in alkali metalscharacteristics that are detrimental to LAW grout formation and/or performance. Several options, ranging from simple evaporation to thermal-chemical denitration, are being considered as cost-effective preconditioning steps to be incorporated into the grouting process. The Idaho National Engineering and Environmental Laboratory (INEEL) strategy to treat and dispose of the LAW is to design a process specifically for denitrating the LAW derived from SBW (expected to present the most challenge for denitration) with the assumption that the same, or similar, process will work for the aluminum and zirconium-derived calcine LAW, another waste stream that will be generated during the separations process.

Two calcination approaches are being evaluated for denitrating LAW after it is concentrated in an evaporation process. These two methods are 1) high-temperature calcination, which INEEL has used to calcine high-level waste (HLW) stored in underground tanks at the ICPP, and 2) thermochemical denitration using lower-temperature calcination with chemical reductants. In the proposed high-temperature calcination process for LAW, waste is heated to temperatures of about $600^{\circ} \mathrm{C}$ to $700^{\circ} \mathrm{C}$, and the nitrates decompose to nitrogen oxides $\left(\mathrm{NO}_{x}\right)$, primarily $\mathrm{NO}$ and $\mathrm{NO}_{2}$. A denitrated residue is generated that can then be combined with grout formers. Although the large quantity of $\mathrm{NO}_{x}$ generated by the hightemperature calcination results in a highly corrosive and toxic offgas, results from testing with $\mathrm{HLW}$ show that high-temperature thermal denitration of the waste is effective in reducing the nitrate concentration and producing a grout-compatible HLW calcine. However, this process has not yet been fully evaluated for the LAW waste stream.

The second processing alternative, using reductant addition to denitrate the LAW, can potentially reduce calcination temperatures to $250^{\circ} \mathrm{C}$ to $400^{\circ} \mathrm{C}$ and can convert a significant portion (50\% to $70 \%$ ) of the nitrate in the waste to nitrogen gas $\left(\mathrm{N}_{2}\right)$, with the remaining fraction being converted to $\mathrm{N}_{2} \mathrm{O}$ and $\mathrm{NO}_{\mathrm{x}}$. Decreasing the denitration temperatures for the LAW can minimize volatilization of radionuclides and hazardous constituents (e.g., $\mathrm{Hg}$ ). Therefore, the advantages of thermochemical denitration with reductant addition are 1) $50 \%$ to $70 \%$ reduction in $\mathrm{NO}_{\mathrm{x}}$, which will reduce offgas treatment and cost, and 
2) lower operating temperature. Another benefit of reductant addition is that the denitration reactions proceed rapidly, allowing for a high process throughput.

The principal objective of this project was to define thermal treatment processing conditions that will safely and consistently process the LAW stream into a denitrated, flowable solids product, suitable for grouting and disposal at INEEL. Initial work was conducted by PNNL in FY 1997 to denitrate simulated LAW through reductant addition while minimizing the amount of $\mathrm{NO}_{\mathrm{x}}$ in the process offgas. Laboratory testing was conducted at PNNL to provide analytical data and laboratory- and bench-scale experimental data to help 1) identify optimum denitration process conditions, 2) develop a mass and energy balance of the process (including calciner and offgas equipment), 3) identify and evaluate commercially applicable technologies, and 4) evaluate alternative flowsheets for full-scale process implementation. Activities in FY 1997 involved beaker calcination scoping tests, preliminary pot calciner tests, and distillation tests. Work in FY 1998 provided further distillation testing and reductant denitration testing, including reaction calorimetry testing; pot calciner testing; and bench-scale rotary calciner testing using different reductants and operating conditions. The FY 1998 work also included engineering evaluations and preliminary flowsheet development. Results from testing and evaluation activities at PNNL on the reductant addition process and results from similar activities being conducted by INEEL on high-temperature calcination will be used to select the preferred process for preconditioning the LAW.

\subsection{Thermochemical Denitration by Reductant Addition-Technology Description}

The LAW derived from ICPP SBW is projected to be a clear acidic liquid with no suspended solids. The total dissolved solids content (consisting mostly of nitrate salts) is estimated to be approximately $230 \mathrm{~g} / \mathrm{L}$. The projected nitric acid (added to the LAW) is approximately 0.65 moles/liter. (See Section 3.0 for composition of LAW simulant.) Furthermore, the transition metal nitrate salts, e.g., $\mathrm{Al}\left(\mathrm{NO}_{3}\right)_{3}$ and $\mathrm{Fe}\left(\mathrm{NO}_{3}\right)_{3} \cdot 9 \mathrm{H}_{2} \mathrm{O}$, can undergo hydrolysis to form metal hydroxides and generate additional nitric acid. Accounting for the free nitric acid and the nitric acid potentially generated through hydrolysis, approximately $60 \%$ of the nitrate in the feed could be removed as nitric acid. This nitric acid can be removed via distillation or through destruction by chemical reaction. The bottoms remaining will still be high in nitrate, but will be much more basic and amenable to drying with or without added reductant. This type of dried salt waste is similar to wastes that have been successfully treated with reductants to denitrify them with the production of $\mathrm{N}_{2}$ and relatively small amounts of $\mathrm{NO}_{\mathbf{x}}$.

This stream (on a dry weight basis) is approximately $80 \%$ nitrate. The denitration reaction for the nitrate and carbohydrate proceeds as follows:

$$
1.25 \mathrm{C}_{\mathrm{n}} \mathrm{H}_{2 \mathrm{n}} \mathrm{O}_{\mathrm{n}}+\mathrm{nNaNO}_{3} \longrightarrow(0.5 \mathrm{n}) \mathrm{N}_{2} \uparrow+(0.75 \mathrm{n}) \mathrm{CO}_{2} \uparrow+(1.25 \mathrm{n}) \mathrm{H}_{2} \mathrm{O} \uparrow+(0.5 \mathrm{n}) \mathrm{Na}_{2} \mathrm{CO}_{3}
$$

There are several important advantages of the approach evaluated in the PNNL studies over conventional thermal denitration techniques: 
- Higher levels of denitration can be achieved. While thermal denitration at $700^{\circ} \mathrm{C}$ for $8 \mathrm{hr}$ has shown denitration efficiencies of $60 \%$ to $75 \%$ with the LAW, with reductant addition, greater than $90 \%$ denitration was achieved at less than $300^{\circ} \mathrm{C}$ in $20 \mathrm{~min}$.

- Approximately $50 \%$ to $70 \%$ of the nitrates destroyed are converted to $\mathrm{N}_{2}$, with the remaining fraction being converted to $\mathrm{N}_{2} \mathrm{O}$ and $\mathrm{NO}_{\mathbf{x}}$. During high-temperature calcination, the materials are typically heated to a temperature $\left(600^{\circ} \mathrm{C}\right.$ to $\left.700^{\circ} \mathrm{C}\right)$ that causes the majority of nitrates to decompose to nitrogen oxides (principally $\mathrm{NO}_{\mathrm{x}}$ ) with a minimum generation of $\mathrm{N}_{2}$. With the addition of a simple reductant, the cost to prevent the formation of $\mathrm{NO}_{\mathrm{x}}$ is estimated to be only a small fraction of the costs normally incurred for abatement of $\mathrm{NO}_{\mathbf{x}}$ from radioactive waste processing.

- More conventional equipment and materials of construction can be used, since denitration is effective at lower temperatures.

- Using a simple distillation process before the denitration/reductant addition step will remove water and the bulk of the nitric acid from the waste and, in turn, will lessen the energy and offgas treatment burden on the calciner.

\subsection{Report Organization}

The work performed by PNNL is discussed in the report as follows: Section 2.0 lists the chronology and accomplishments. Section 3.0 identifies the simulant compositions used throughout the testing. Section 4.0 describes the distillation process and tests. Section 5.0 details the denitration via reductant addition process and testing, including the chemistry of reductant addition, scoping tests, reaction calorimetry, and pot calciner and bench-scale rotary calciner testing. Section 6.0 provides the engineering evaluation of alternative flowsheets. The appendices contain an overview of various denitration processes (Appendix A); a literature review (Appendix B); run observations and data from rotary calciner tests (Appendix C); a bibliography (Appendix D); and additional reaction calorimetry plots (Appendix E). 


\subsection{Work Conducted and Accomplishments}

The purpose of this report is to discuss the work conducted under the Technical Task Plan (TTP) No. RL3-7-WT-31 (Task 2) PNNL Immobilization-LAW Waste Form for Idaho (Grout). The overall objective of this task was to provide data to identify and demonstrate a technically viable and costeffective process for conditioning INEEL acidic LAW for immobilization. Activities and accomplishments addressing this objective are itemized below.

\subsection{Chronology of Activities}

The following timeline highlights key activities and milestones:

December 1996

Denitration proposal submitted to Tank Focus Area (TFA), DOE/Office of Technology Development.

April 1997

Proposal accepted by TFA.

June 1997

Workshop at INEEL to kick off project.

June 1997

TFA issues final program execution guidance.

July 1997

PNNL Test Plan submitted to TFA for review.

August 1997

Comments on Test Plan received from TFA.

September 1997

Draft interim report issued.

November 1997 Evaporation testing completed and samples submitted for analysis.

Test plan for rotary calciner completed for review.

December 1997 Evaporation test samples analyzed.

Scoping tests with grout-compatible materials initiated.

January 1998

Four runs completed on bench-scale rotary calciner.

February 1998 Three additional runs completed on bench-scale rotary calciner, including flyash from INEEL.

March 1998

Reaction calorimetry testing performed.

April 1998

Review of industrial calciner equipment started. 
May-August 1998 Review of industrial equipment identified glycine denitration (Glycine Nitrate) and COGEMA systems as most applicable to thermochemical denitration.

September 1998 Pilot-scale glycine denitration system returned to PNNL test facility for potential future testing.

\subsection{Key Accomplishments}

The key accomplishments for this project are listed as follows:

\subsubsection{Testing}

- Evaporation testing-Four evaporation tests were completed and samples analyzed.

- Pot calciner testing-A series of pot calciner tests were completed using different reductants, reductant:nitrate ratios, and cover gases. The offgases from the tests were analyzed continuously.

- Bench-scale rotary calciner-Eight bench-scale rotary calciner tests were completed and included analysis of the gases and residual solids.

- Reaction calorimetry-A series of reaction calorimetry tests were completed, identifying initiation temperatures and reaction energies.

\subsubsection{Engineering Evaluation}

- Review of applicable commercial calciner equipment completed.

- Evaporation modeling completed using OLI's ESP modeling software. 


\subsection{Simulant Compositions}

A LAW simulant composition (Table 3.1), provided by INEEL staff, was used as the basis for preparing feed material for the denitration tests. The only modifications were to exclude some of the minor, but toxic (e.g., mercury), components from simulants used in initial tests.

All testing for the reductant addition process was performed using LAW or LAW bottoms (the estimated composition remaining after vacuum distillation and reconstituted to $1-L$ volume). (Note that the simulated bottoms in Table 3.1 are about two thirds the concentration of the actual bottoms. Fully concentrated bottoms precipitate salts on cooling, which would make the simulant more difficult to handle accurately.] The composition given for the LAW bottoms (Table 3.1) is based on the batching weights. The revised compositions listed in Table 3.1 were not used for two reasons: 1) the LAW is thought to be the most difficult to handle, so the $\mathrm{Al}+\mathrm{Zr}$ LAW (revised) material should not present any new problems; 2) the LAW (revised) is essentially a diluted version of the LAW used for testing and, therefore, adds no change other than the need to remove more water.

Inert components, such as Micro-Cel $\mathrm{E}$ (a synthetic calcium silicate), were also used in testing because they might be part of a waste or might be added to the waste. Micro-Cel $E$ is found in many Mixed Waste Focus Area wastes because it was used to consolidate the hazardous components. It was used with the INEEL LAW because it works as a reaction retardant and appears to be compatible with grout compositions. Flyash is known to be a good grout component and may serve the same reaction retardant function as Micro-Cel E. Table 3.2 gives the composition of these materials. 
Table 3.1. LAW (derived from SBW) Simulant Composition

\begin{tabular}{|c|c|c|c|c|}
\hline \multirow[b]{2}{*}{ Element/Anion } & \multicolumn{4}{|c|}{ Concentration Values Are in Moles per Liter } \\
\hline & $\begin{array}{c}\text { Al+Zr LAW } \\
\text { (revised) }\end{array}$ & $\begin{array}{c}\text { LAW } \\
\text { (revised) }\end{array}$ & $\begin{array}{l}\text { LAW (used } \\
\text { for testing) }\end{array}$ & $\begin{array}{c}\text { LAW } \\
\text { Bottoms-Used } \\
\text { for Teșting }\end{array}$ \\
\hline $\mathrm{Al}^{+3}$ & $1.05 \mathrm{E}-01$ & $8.52 \mathrm{E}-02$ & $1.90 \mathrm{E}-01$ & $6.6 \mathrm{E}-01$ \\
\hline $\mathrm{B}^{+3}$ & $9.32 E-03$ & $2.53 \mathrm{E}-03$ & $5.67 \mathrm{E}-03$ & $1.87 \mathrm{E}-02$ \\
\hline $\mathrm{Ca}^{+2}$ & $9.67 \mathrm{E}-02$ & $3.17 \mathrm{E}-02$ & $7.08 \mathrm{E}-02$ & $2.36 \mathrm{E}-01$ \\
\hline $\mathrm{Cd}^{+2}$ & & $3.82 \mathrm{E}-04$ & 8.50E-04 & 2.82E-03 \\
\hline $\mathrm{Cl}^{-}$ & $3.66 \mathrm{E}-04$ & $3.47 \mathrm{E}-03$ & $7.74 \mathrm{E}-03$ & $3.14 \mathrm{E}-02$ \\
\hline $\mathrm{Cr}^{+3}$ & $6.29 \mathrm{E}-04$ & $3.85 \mathrm{E}-04$ & $8.60 \mathrm{E}-04$ & $2.88 \mathrm{E}-03$ \\
\hline $\mathrm{Cs}^{+}$ & $4.16 \mathrm{E}-09$ & 4.67E-09 & $1.37 \mathrm{E}-08$ & \\
\hline $\mathrm{F}^{-}$ & $1.70 \mathrm{E}-01$ & $9.11 \mathrm{E}-03$ & $2.03 \mathrm{E}-02$ & $6.86 \mathrm{E}-01$ \\
\hline $\mathrm{Fe}^{+3}$ & $9.40 \mathrm{E}-04$ & $2.84 \mathrm{E}-03$ & $6.32 \mathrm{E}-03$ & $2.14 \mathrm{E}-02$ \\
\hline $\mathrm{Gd}^{+3}$ & $1.03 \mathrm{E}-07$ & & & \\
\hline $\mathrm{Hg}^{+2}$ & $2.61 \mathrm{E}-06$ & $8.93 \mathrm{E}-08$ & $2.43 \mathrm{E}-04$ & \\
\hline $\mathrm{K}^{+}$ & $9.24 \mathrm{E}-04$ & $2.74 \mathrm{E}-02$ & $5.31 \mathrm{E}-02$ & $1.77 \mathrm{E}-01$ \\
\hline $\mathrm{Mg}^{+2}$ & $1.68 \mathrm{E}-03$ & & & \\
\hline $\mathrm{Mn}^{+2}$ & & $1.56 \mathrm{E}-03$ & $3.47 \mathrm{E}-03$ & $1.16 \mathrm{E}-02$ \\
\hline $\mathrm{Na}^{+}$ & $2.08 \mathrm{E}-02$ & $2.38 \mathrm{E}-01$ & $5.16 \mathrm{E}-01$ & $1.79 E+00$ \\
\hline $\mathrm{Ni}^{+2}$ & $1.84 \mathrm{E}-04$ & $1.53 \mathrm{E}-03$ & $3.40 \mathrm{E}-03$ & $1.13 \mathrm{E}-02$ \\
\hline $\mathrm{NO}_{3}^{-}$ & $1.04 \mathrm{E}+00$ & $1.32 \mathrm{E}+00$ & $2.58 \mathrm{E}+00$ & $4.55 \mathrm{E}+00$ \\
\hline $\mathrm{PO}_{4}^{-3}$ & $4.27 \mathrm{E}-04$ & $2.50 \mathrm{E}-02$ & $4.15 \mathrm{E}-03$ & $1.35 \mathrm{E}-02$ \\
\hline $\mathrm{SO}_{4}^{-2}$ & $3.61 \mathrm{E}-05$ & $6.08 \mathrm{E}-03$ & $1.36 \mathrm{E}-02$ & $4.62 \mathrm{E}-02$ \\
\hline $\mathrm{Zr}^{+4}$ & $1.41 \mathrm{E}-02$ & $2.84 \mathrm{E}-04$ & $5.01 \mathrm{E}-04$ & $1.68 \mathrm{E}-03$ \\
\hline $\mathrm{Ag}^{+}$ & & $2.15 \mathrm{E}-06$ & & $7.19 \mathrm{E}-06$ \\
\hline $\mathrm{As}^{+3}$ & & $4.76 \mathrm{E}-06$ & $1.06 \mathrm{E}-05$ & \\
\hline $\mathrm{Ba}^{+2}$ & & $5.67 \mathrm{E}-06$ & $1.52 \mathrm{E}-11$ & \\
\hline $\mathrm{Mo}^{+6}$ & & $8.09 \mathrm{E}-08$ & $6.09 \mathrm{E}-17$ & \\
\hline $\mathrm{Pb}^{+2}$ & & $3.27 \mathrm{E}-06$ & $6.02 \mathrm{E}-10$ & \\
\hline $\mathrm{Se}^{+4}$ & & $2.50 \mathrm{E}-06$ & $5.57 \mathrm{E}-06$ & \\
\hline $\mathrm{NH}_{4}^{+}$ & $1.41 \mathrm{E}-02$ & & & \\
\hline $\mathrm{H}^{+}$ & $5.01 \mathrm{E}-01$ & $7.36 \mathrm{E}-01$ & $1.32 \mathrm{E}+00$ & \\
\hline $\mathrm{CO}_{3}^{-2}$ & $3.01 \mathrm{E}-03$ & & $5.66 \mathrm{E}-02$ & \\
\hline $\begin{array}{l}\text { Ammonium } \\
\text { Citrate }\end{array}$ & $7.51 \mathrm{E}-04$ & $2.31 \mathrm{E}-03$ & & \\
\hline
\end{tabular}


Table 3.1. (contd)

\begin{tabular}{||c|c|c|c|c||}
\hline \multirow{2}{*}{ Element/Anion } & \multicolumn{4}{|c|}{ Concentration Values Are in Moles per Liter } \\
\cline { 2 - 5 } & $\begin{array}{c}\text { Al+Zr LAW } \\
\text { (revised) }\end{array}$ & $\begin{array}{c}\text { LAW } \\
\text { (revised) }\end{array}$ & $\begin{array}{c}\text { LAW (used } \\
\text { for testing) }\end{array}$ & $\begin{array}{c}\text { LAW } \\
\text { Bottoms-Used } \\
\text { for Testing }\end{array}$ \\
\hline $\mathrm{NaNO}_{2}$ & & & $2.28 \mathrm{E}-04$ & \\
\hline Note: blank $=$ not present. & & & \\
\hline
\end{tabular}

Table 3.2. Inert Materials Used in the TFA-INEEL Denitration Studies and Potential Use with Other Waste Systems

\begin{tabular}{||l|c|c|c||}
\hline Component wt\% & Micro-Cel E & Flyash & INEEL Calcine \\
\hline Moisture & 16 & - & -- \\
\hline $\mathrm{SiO}_{2}$ & 47 & 54.75 & -- \\
\hline $\mathrm{CaO}$ & 32 & -- & $1-13.5$ \\
\hline $\mathrm{Al}_{2} \mathrm{O}_{3}$ & 2.5 & 21.90 & $6-90$ \\
\hline $\mathrm{Fe}_{2} \mathrm{O}_{3}$ & 0.7 & 6.65 & $0.03-10$ \\
\hline $\mathrm{MgO}$ & 0.6 & -- & -- \\
\hline $\mathrm{Na}_{2} \mathrm{O}+\mathrm{K}_{2} \mathrm{O}$ & 1.2 & -- & $0.5-7.5$ \\
\hline $\mathrm{CaF}_{2}$ & -- & -- & $1-55$ \\
\hline $\mathrm{ZrO}_{2}$ & -- & -- & $0-26$ \\
\hline $\mathrm{SO}_{4}$ & -- & -- & $0.3-13$ \\
\hline $\mathrm{NaNO}_{3}$ & -- & -- & $0-6$ \\
\hline $\mathrm{CdO}$ & -- & -- & $0.1-8$ \\
\hline $\mathrm{B}_{2} \mathrm{O}_{3}$ & -- & -- & $0.5-3.5$ \\
\hline $\mathrm{Gd}_{2} \mathrm{O}_{3}$ & -- & -- & $0-6$ \\
\hline
\end{tabular}




\subsection{LAW Preconditioning-Removal of Nitric Acid by Distillation}

The acidic LAW simulant described in Section 3.0 is an unsaturated (at room temperature), acidic nitrate solution. Most of the mass of the simulant is water, and approximately $50 \mathrm{wt} \%$ of the total nitrate is present as nitric acid. If this waste stream is fed directly to a calciner for nitrate destruction, all of this water will be evaporated, and most of the nitric acid will be converted to $\mathrm{NO}_{\mathrm{x}}$ in the calciner. Evaporating water and converting nitric acid to $\mathrm{NO}_{\mathrm{x}}$ will significantly increase the energy requirements, the offgas treatment requirements, and the cost of the calciner. On the other hand, water and nitric acid may be removed from the waste by evaporation in a separate preceding step. In that case, water is not evaporated in the calciner and can be handled more easily in standard, commercially available, distillation equipment. Furthermore, the energy requirements for the calciner are much lower. By a simple distillation process, the water and a fairly concentrated nitric acid stream (azeotrope for nitric acid is $\sim 70 \%$ ) can be produced in separate streams, which makes the acid available for recycling. Removing acidic nitrate prior to thermochemical denitration also decreases the amount of reductant used.

Boiling nitric acid solutions containing significant quantities of other dissolved salts and metals may decompose some of the nitric acid to gaseous $\mathrm{NO}_{\mathrm{x}}$. Vacuum evaporation can lower the boiling point of the liquid below the temperature where the nitric acid decomposes, enabling a large fraction of the water and nitric acid to be removed with minimal $\mathrm{NO}_{\mathrm{x}}$ evolution. In addition, operating at a vacuum should reduce the relative vapor pressure of metal salts such as mercury, thereby minimizing the contamination of hazardous metals in the recovered acid and water. Finally, as the LAW is concentrated by atmospheric or vacuum evaporation, crystals will eventually form. In terms of operating the commercial equipment, understanding the concentration and temperature that allow crystals to form will be important to minimize operational difficulties.

For this study, three batch distillation experiments were performed using the acidic LAW simulant at the following conditions:

- $125 \mathrm{mmHg}$ absolute (duplicate of an experiment performed in FY 1997)

- $500 \mathrm{mmHg}$ absolute

- atmospheric pressure or $\sim 760 \mathrm{mmHg}$ absolute.

\subsection{Equipment}

The test apparatus (see Figure 4.1) consisted of a boiling flask heated by an electrical heating mantle, topped with a water-cooled condenser and a condensate receiver. A packed column was placed between the boiling flask and the condenser to remove aerosols that might otherwise be carried over into the condensate. The entire system was placed under vacuum and regulated at a preselected setpoint by an electronic vacuum controller. During the testing, temperatures of the simulant bottoms and the vapor above the packed column were monitored by Teflon-coated type $\mathrm{K}$ thermocouples. Samples of the bottoms were also removed to determine crystallization behavior. 


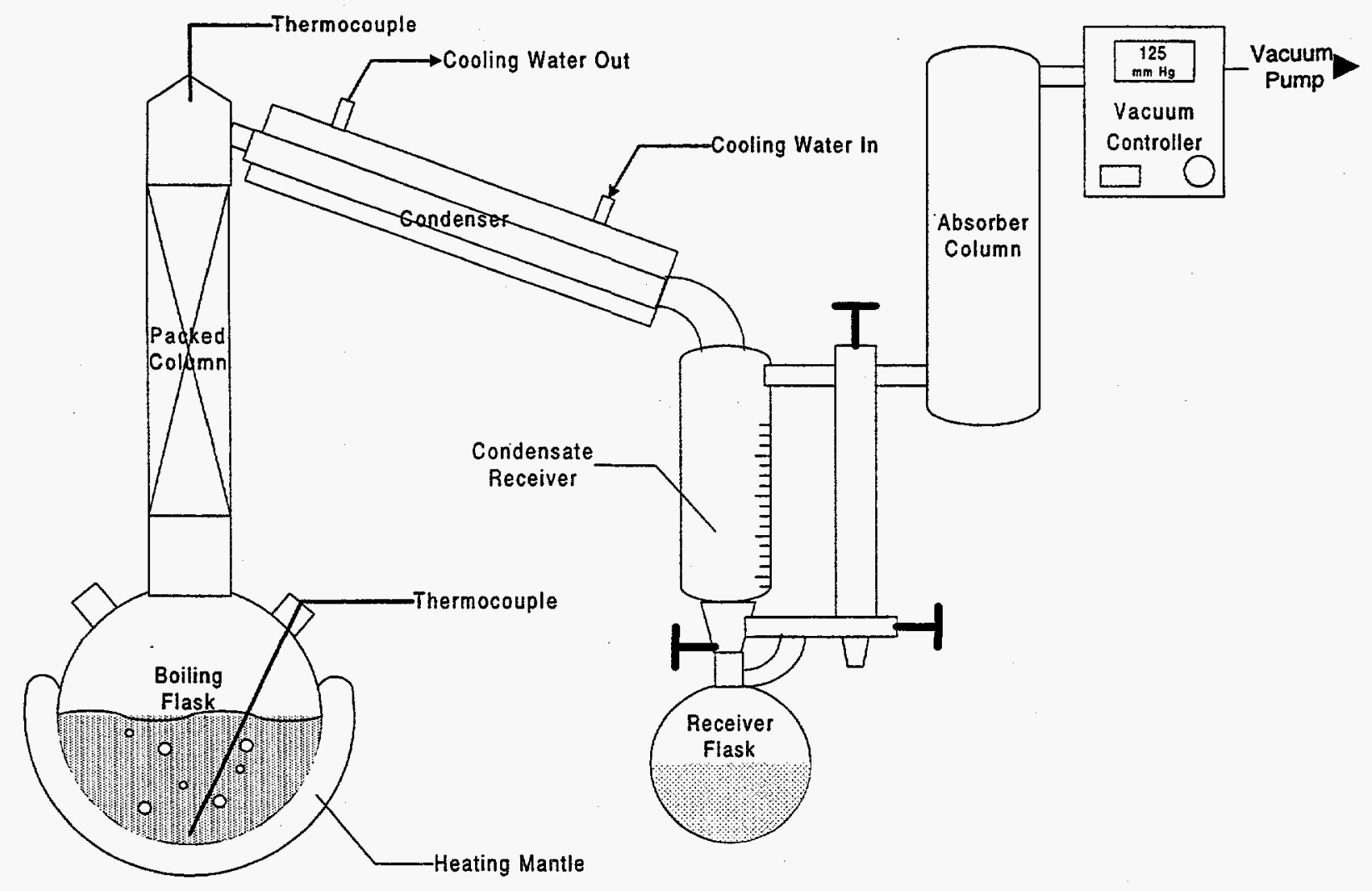

Figure 4.1. Apparatus for Vacuum Distillation of Simulated LAW

\subsection{Test Methods and Conditions}

Approximately $300 \mathrm{~g}(\sim 300 \mathrm{~mL})$ of LAW simulant were placed into the boiling flask. The system was sealed, and the vacuum was adjusted to the required setpoint. The heating mantle heated the LAW to its boiling point, which, at $125 \mathrm{mmHg}$ vacuum, was $\sim 63^{\circ} \mathrm{C}$; at $500 \mathrm{mmHg}$, the initial boiling point was $95^{\circ} \mathrm{C}$; and at atmospheric pressure $(760 \mathrm{mmHg})$, the initial boiling point was $103^{\circ} \mathrm{C}$. The temperature profile was fairly flat at the initial boiling temperature for most of the test, increasing at the end as the salt solution became more concentrated. The final temperature at every condition was $118^{\circ} \mathrm{C}$ to $120^{\circ} \mathrm{C}$, because boiling temperatures for these salt slurries are determined by the volatile liquid water and nitric acid remaining in the bottoms slurry. As the volatile liquids are evaporated from the solution, the boiling point of the concentrated "molten" salt is nearly independent of the vacuum or pressure, and the boiling point reaches nearly the same value at all conditions. However, the volatile acids are evaporated at lower temperatures. For example, the nitric acid was removed at less than $90^{\circ} \mathrm{C}$ at $125 \mathrm{mmHg}$ vacuum, while the nitric acid was removed at over $115^{\circ} \mathrm{C}$ at $760 \mathrm{mmHg}$. The condensate was collected in a receiver at the discharge of the condenser. Samples of the condensate were collected in $\sim 50-\mathrm{mL}$ aliquots for later analysis. The bottom sample was evaporated to near dryness when the test was completed. 


\subsection{Results and Discussion}

The temperature and condensate compositions for each condition are shown in Figures 4.2 through 4.4. The offgas was not analyzed for noncondensibles. Observations of each test are shown in Table 4.1. Throughout the test at $125 \mathrm{mmHg}$, no visible brown $\mathrm{NO}_{\mathrm{x}}$ gas was seen evolving from the boiling liquid, which indicates that the evaporation process was maintained below the decomposition temperature of the nitric acid. The simulated LAW is an acidic liquid containing no suspended solids. The projected nitric acid concentration (added to the simulated LAW as nitric acid) is approximately 1.3 moles/liter. Additionally, the transition metal nitrate salts, e.g., $\mathrm{Al}\left(\mathrm{NO}_{3}\right)_{3}$ and $\mathrm{Fe}\left(\mathrm{NO}_{3}\right)_{3} \cdot 9 \mathrm{H}_{2} \mathrm{O}$, can undergo hydrolysis to form metal hydroxides and generate additional nitric acid. Accounting for the free nitric acid and the nitric acid potentially generated through hydrolysis, approximately $50 \%$ of the nitrate in the feed could be removed by distillation as nitric acid.

Figures 4.2 through 4.4 also show the approximate times the 30 - to $50-\mathrm{mL}$ condensate samples were taken. These samples were analyzed by ion chromatography (IC) for anions. The first $70 \mathrm{wt} \%$ (relative to the starting mass of simulant) was mostly water with very little acid $(\mathrm{pH} \sim 4)$. The final condensate sample contained $~ 90 \%$ of the total recovered nitric acid in the starting material.

Essentially no carryover of aerosols occurred during the distillation as seen by the inductively coupled plasma (ICP) analysis of the final condensate at $125 \mathrm{mmHg}$ vacuum (Table 4.2). The decontamination factors (concentrated bottoms concentration/condensate concentration) ranged from $10^{4}$ to $10^{6}$, typical for single stage evaporation; 20 to $40 \mathrm{wt} \%$ of the hydrochloric and 1 to $2 \mathrm{wt} \%$ of the hydrofluoric acids from the starting material were also distilled and collected in the condensates. The mercury concentrations in the initial condensates ranged from 10 to $2000 \mathrm{ppb}$ compared with a feed concentration of $42,000 \mathrm{ppb}$. Less than $1 \%$ of the $\mathrm{Hg}$ was evaporated into the condensate. This result matches well with the expected concentration for $\mathrm{HgCl}_{2}$.

These tests show that $90 \mathrm{wt} \%$ of the water and nitric acid can be evaporated from the waste before the calcining step begins, thereby reducing the burden on the calciner. The nitric acid can be recovered in a concentrated form that may be suitable for reuse rather than contributing to the $\mathrm{NO}_{\mathrm{x}}$ abatement requirements for the calciner offgas treatment system, the caustic addition requirements for the calciner feed, etc. Although the bottoms were evaporated to near dryness (with crystallized salts present even at boiling temperature), the salts did not clump together into a hard crust coating the flask. The final bottoms solution contained 50 to $70 \mathrm{wt} \%$ nitrate, representing approximately a 6 to $8 \mathrm{M}$ solution. Most of the salts were poured out with the little remaining liquid. The rest of the residual crystals were easily rinsed out with a small amount of distilled water. All of the precipitated salts were redissolved with the addition of about $1: 1$ by mass of distilled water ( $\sim 30 \mathrm{~g}$ salt slurry was dissolved by adding $\sim 30 \mathrm{~g}$ distilled water) to facilitate elemental analysis. 


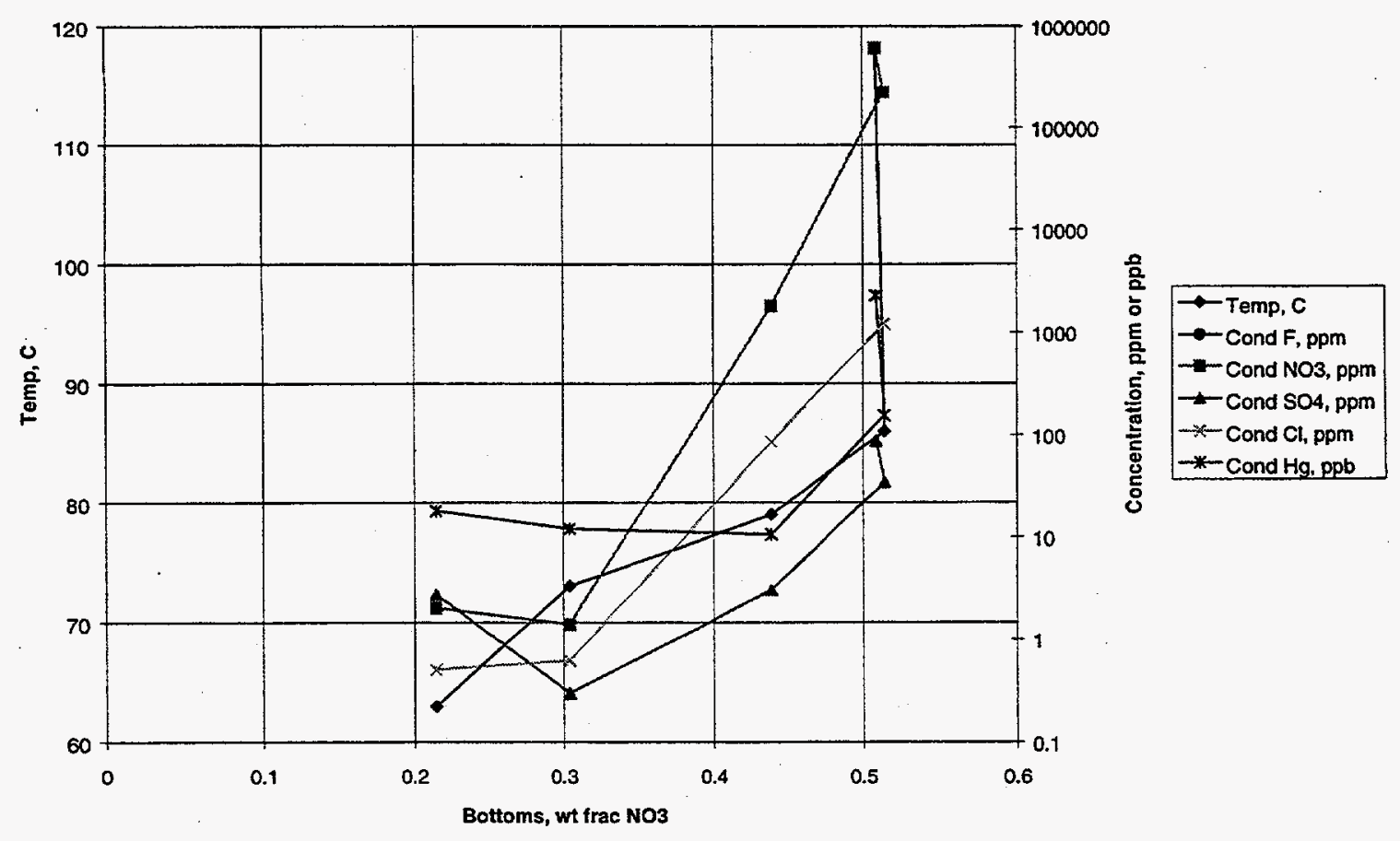

Figure 4.2. Temperature and Concentration Profiles at $125 \mathrm{mmHg}$ Data

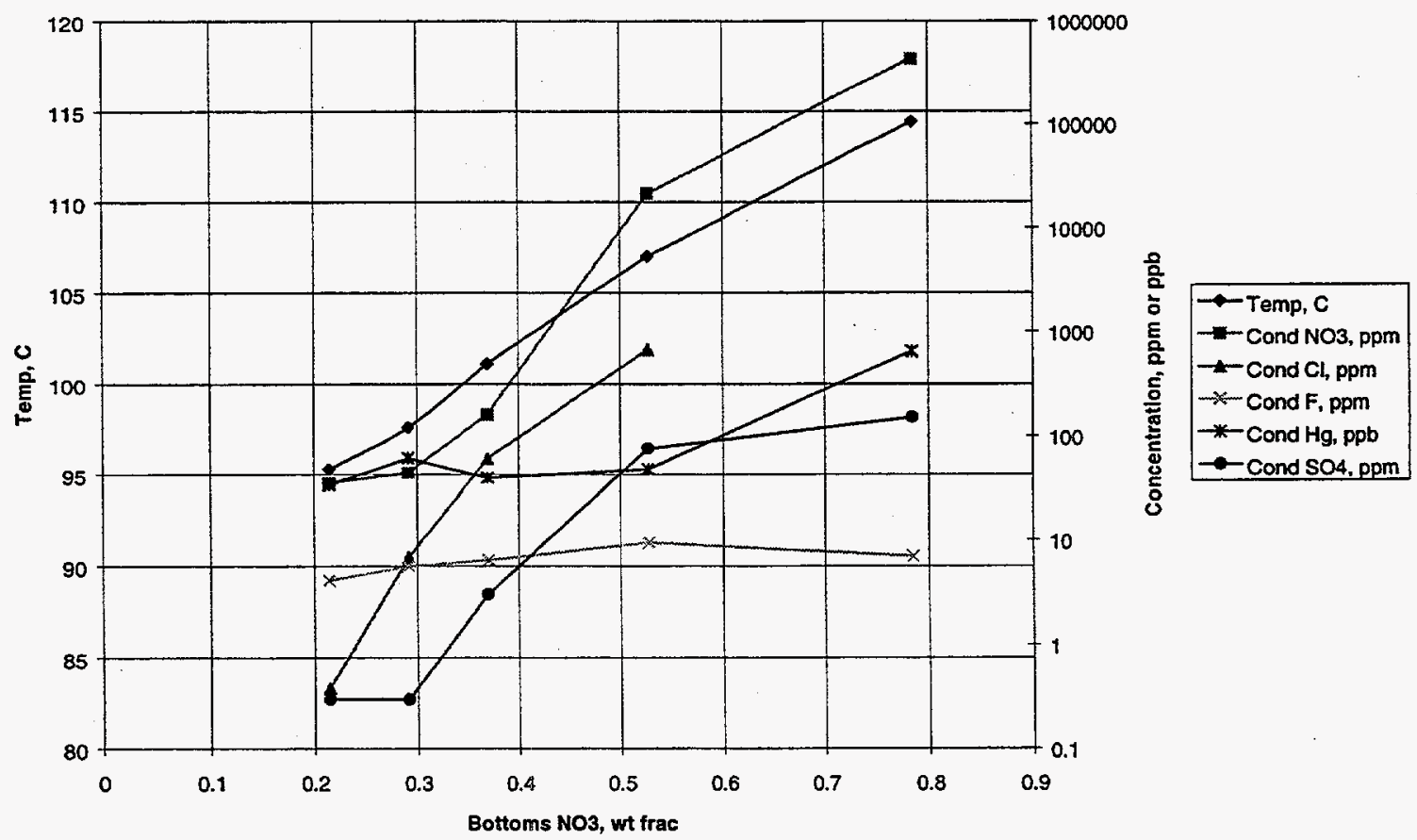

Figure 4.3. Temperature and Concentration Profiles at $500 \mathrm{mmHg}$ 


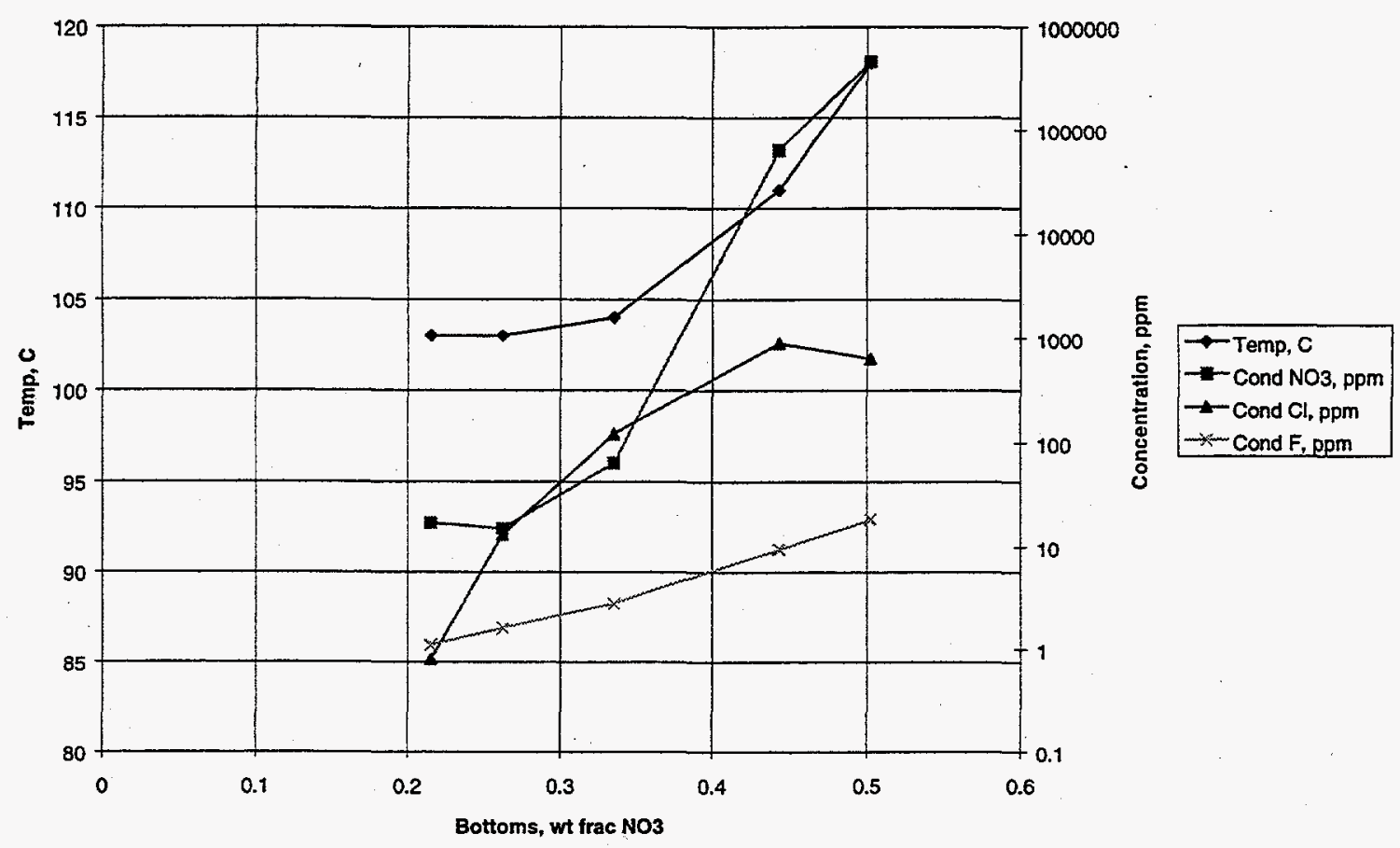

Figure 4.4. Temperature and Concentration Profiles at $760 \mathrm{mmHg}$

Table 4.1. Summary of Distillation Tests

\begin{tabular}{|l|l|c|c|}
\hline \multicolumn{1}{|c|}{ Run } & \multicolumn{1}{|c|}{ Observations } & \multicolumn{1}{c|}{$\begin{array}{c}\text { Initial/Final BP } \\
\text { Temp., }{ }^{\circ} \mathrm{C}\end{array}$} & $\begin{array}{c}\text { Nitrate Acid } \\
\text { Evaporated wt\% of } \\
\text { Starting Amount }\end{array}$ \\
\hline $125 \mathrm{mmHg}$ & No $\mathrm{NO}_{\mathrm{x}}$ & $63 / 117$ & 100 \\
\hline $500 \mathrm{mmHg}$ & Slight $\mathrm{NO}_{\mathrm{x}}$ at end & $93 / 119$ & 53 \\
\hline $760 \mathrm{mmHg}$ & Slight $\mathrm{NO}_{\mathrm{x}}$ at end & $103 / 120$ & 74 \\
\hline $\mathrm{BP}=$ boiling point.
\end{tabular}


Table 4.2. Analyses of LAW Simulant, Distillation Condensates, and Final Still Bottoms at $125 \mathrm{mmHg}$

\begin{tabular}{|l|l|l|l|l|l|l|l|}
\hline & $\begin{array}{c}\text { LAW } \\
\text { Simulant }\end{array}$ & $\begin{array}{c}\text { First } \\
\text { Cond. }\end{array}$ & $\begin{array}{c}\text { Second } \\
\text { Cond. }\end{array}$ & $\begin{array}{c}\text { Third } \\
\text { Cond. }\end{array}$ & $\begin{array}{c}\text { Fourth } \\
\text { Cond. }\end{array}$ & $\begin{array}{c}\text { Final } \\
\text { Cond. }\end{array}$ & $\begin{array}{c}\text { Final Still } \\
\text { Bottoms } \\
\text { (solids and } \\
\text { supernatants) }\end{array}$ \\
\hline Mass, g $=$ & 299.1 & 48.81 & 49.77 & 50.35 & 50.35 & 50.21 & 34.64 \\
\hline Density $=$ & 1.11 & 1.0 & 1.0 & 1.0 & 1.05 & 1.18 & 1.6. \\
\hline $\begin{array}{l}\text { Analytes; } \\
\text { units }=\end{array}$ & mg/L & mg/L & mg/L & mg/L & mg/L & mg/L & mg/g \\
\hline $\mathrm{Al}$ & 5600 & NA & NA & NA & NA & 0.14 & 37.4 \\
\hline $\mathrm{B}$ & 69 & NA & NA & NA & NA & 0.026 & 0.52 \\
\hline $\mathrm{Ba}$ & 0.11 & NA & NA & NA & NA & 0.0011 & $8.70 \mathrm{E}-04$ \\
\hline $\mathrm{Ca}$ & 2900 & NA & NA & NA & NA & 0.13 & 21.91 \\
\hline $\mathrm{Cd}$ & 10 & NA & NA & NA & NA & & 0.077 \\
\hline $\mathrm{Cr}$ & 46 & NA & NA & NA & NA & & 0.342 \\
\hline $\mathrm{Fe}$ & 365 & NA & NA & NA & NA & 0.099 & 2.71 \\
\hline $\mathrm{K}$ & 2200 & NA & NA & NA & NA & 0.05 & 16.75 \\
\hline $\mathrm{Mg}$ & 0.11 & NA & NA & NA & NA & 0.0068 & $1.20 \mathrm{E}-03$ \\
\hline $\mathrm{Mn}$ & 200 & NA & NA & NA & NA & 0.0092 & 1.42 \\
\hline $\mathrm{Mo}$ & & NA & NA & NA & NA & 0.05 & $9.20 \mathrm{E}-04$ \\
\hline $\mathrm{Na}$ & 10300 & NA & NA & NA & NA & 0.081 & 79.9 \\
\hline $\mathrm{Ni}$ & 230 & NA & NA & NA & NA & 0.07 & 1.68 \\
\hline $\mathrm{Zr}$ & 0 & NA & NA & NA & NA & 0 & 0.027 \\
\hline $\mathrm{F}$ & 119 & 0.44 & 0.65 & 0.91 & 1.88 & 75 & 563 \\
\hline $\mathrm{Cl}$ & 230 & 0.18 & 0.029 & 0.33 & 30 & 645 & 0.21 \\
\hline $\mathrm{NO}{ }_{3}$ & 170000 & 6.6 & 0.56 & 1.6 & 180 & 410000 & 625 \\
\hline $\mathrm{SO}{ }_{4}$ & 1600 & 0.56 & 0.093 & 0.093 & 0.42 & 170 & 10.8 \\
\hline $\mathrm{H}^{+}$ & $(\mathrm{M})$ & & & & & 0.9 & $\mathrm{mmol} / \mathrm{g}$ \\
\hline $\mathrm{NA}=\mathrm{not}$ analyzed. & & & & & 6.36 & 0.033 \\
\hline & & & & & & \\
\hline
\end{tabular}




\subsection{Denitration Testing Via Reductant Addition}

The purpose of adding the reductant is to reduce as much nitrate $\left(\mathrm{NO}_{3}{ }^{-}\right)$to nitrogen $\left(\mathrm{N}_{2}\right)$ as possible while producing as little $\mathrm{NO}_{\mathrm{x}}$ as possible. Thus, the release of $\mathrm{NO}_{\mathrm{x}}$ is eliminated or significantly reduced while the benefits of using thermal denitration are optimized: greatly reduced waste volume; significantly more stable grout form; and relatively simple, inexpensive technology. However, the problem of properly controlling denitration/reductant addition is similar to many oxidizer-fuel reactions, in particular, controlling the quantity of mixed oxidizer and fuel. The combustion engine is an example of a technology where this control is accomplished. The testing described in this section provided data on the nature of the reaction of various reductants with a nitrate waste simulant based on an INEEL LAW composition. These results can be used for identifying an economical engineering method for reacting the nitrate waste with a reductant in a safe, controlled manner.

\subsection{Chemistry of Reductant Addition}

Both low-level and high-level waste simulants (acidic and alkaline) have successfully been denitrated (Eaton 1995; Smith et al. 1996) using sugar without generating large volumes of $\mathrm{NO}_{\mathrm{x}}$ (Meile and Johnson 1984; Beitel 1976a,b and 1977; Bray 1963). A typical reaction for carbohydrates, such as sucrose (sugar), with nitrate proceeds as follows:

$$
12 \mathrm{C}_{\mathrm{n}} \mathrm{H}_{2(\mathrm{n}-1)} \mathrm{O}_{\mathrm{n}-1}+8 \mathrm{nNaNO}_{3} \longleftrightarrow(4 \mathrm{n}) \mathrm{N}_{2} \uparrow+(8 \mathrm{n}) \mathrm{CO}_{2} \uparrow+12(\mathrm{n}-1) \mathrm{H}_{2} \mathrm{O} \uparrow+(4 \mathrm{n}) \mathrm{Na}_{2} \mathrm{O}+4 \mathrm{n} \mathrm{CO} \uparrow
$$

For elemental carbon, the same reaction would be written:

$$
3 \mathrm{C}+2 \mathrm{NaNO}_{3} \longleftrightarrow \mathrm{N}_{2} \uparrow+2 \mathrm{CO}_{2} \uparrow+\mathrm{Na}_{2} \mathrm{O}+\mathrm{CO} \uparrow
$$

Note: These reactions can be written for a range of organic to nitrate ratios with $\mathrm{CO}, \mathrm{N}_{2} \mathrm{O}$, or NO resulting from the reaction, depending on the ratio reactants.

Theoretically, all "nitrate" nitrogen should convert to nitrogen gas if the amount of reductant is added in the proper stoichiometric ratio. However, complete conversion of nitrate to nitrogen gas is typically not observed. Instead, some $\mathrm{NO}_{\mathrm{x}}$ evolves, probably due to the exothermic nature of the above reaction, which leads to hot spots in the waste. At these hot spots, some of the nitrate undergoes a direct thermal breakdown to $\mathrm{NO}_{\mathrm{x}}$, rather than conversion to nitrogen gas.

The thermochemical denitration reactions are exothermic reactions of nitrate, generally with organic reductants that require heating to some elevated temperature to begin the reaction. Decomposition of nitrate by sugar is an example that occurs by the following reaction:

$$
\mathrm{C}_{12} \mathrm{H}_{22} \mathrm{O}_{11}+8 \mathrm{NaNO}_{3} \longleftrightarrow 4 \mathrm{Na}_{2} \mathrm{O}+4 \mathrm{~N}_{2} \uparrow+8 \mathrm{CO}_{2} \uparrow+4 \mathrm{CO} \uparrow+11 \mathrm{H}_{2} \mathrm{O} \uparrow
$$


Carbon can also be introduced into the system in the form of elemental carbon or starch. The use of carbon-containing reducing agents to react with nitrate and nitrite at temperatures below their normal thermal decomposition temperatures (i.e., $\sim 800^{\circ} \mathrm{C}$ ) will increase the total gas evolved (due to the reductant addition) and will convert the alkali metal nitrates and nitrates to carbonates (Ryan 1995). Table 5.1 gives specific energies generated by various organic-nitrate mixtures.

The stoichiometry for the Glycine Nitrate process, developed at PNNL (Chick and Maupin 1995), is very similar to that for the sugar denitration reactions. The reaction is as follows:

$$
10 \mathrm{H}_{2} \mathrm{~N}-\mathrm{CH}_{2}-\mathrm{COOH}+18 \mathrm{NaNO}_{3} \longleftrightarrow 9 \mathrm{Na}_{2} \mathrm{O}+14 \mathrm{~N}_{2} \uparrow+25 \mathrm{H}_{2} \mathrm{O} \uparrow+20 \mathrm{CO}_{2} \uparrow
$$

Once an aqueous solution of glycine and nitrate salt is evaporated to near dryness, a vigorous exothermic reaction ensues, throwing the ash away from the reaction zone due to the high level of gas production. At near-stoichiometric fractions of glycine and nitrate, very little nitrogen ends up as oxides.

The amount of energy generated by these types of reactions is about $2.5 \mathrm{kcal}(10.5 \mathrm{~kJ})$ per gram of fully reacted reductant (carbon and sucrose are about the same per gram). For sucrose, where $n=12$, 1 mole $(342 \mathrm{~g})$ of sucrose will completely reduce 8 moles of $\mathrm{NaNO}_{3}(680 \mathrm{~g})$, so the sugar-to-nitrate ratio for stoichiometric reduction of nitrate is $0.503 \mathrm{~g}$ sugar to $1 \mathrm{~g}$ of sodium nitrate $(0.690 \mathrm{~g}$ sugar per gram of nitrate). The dried acidic LAW simulant is about $80 \mathrm{wt} \%$ nitrate $\left(\mathrm{NaNO}_{3}\right.$ is only $73 \mathrm{wt} \%$ nitrate). Hence, a stoichiometric mixture to completely denitrify $1 \mathrm{~g}$ of waste (dry basis) will contain $0.55 \mathrm{~g}$ of sugar and produce about $1.4 \mathrm{kcal}$ of heat energy. The U.S. Bureau of Mines developed a process for sugar-carbon denitration of high-nitrate, basic LLW, where stoichiometric amounts of reductant were added to the waste ( $25 \mathrm{wt} \%$ ), which was diluted with glass-making components ( $75 \mathrm{wt} \%$ ) (Eaton 1995). This feed displayed good reaction characteristics (controlled though strongly exothermic), and a $65 \%$ to $80 \%$ conversion of nitrate to molecular nitrogen was reported.

Table 5.1. Specific Energy of $\mathrm{NaNO}_{3}$-Organic Reaction (from Beitel 1976b)

\begin{tabular}{|l|c|c|c||}
\hline \multicolumn{1}{|c|}{ Organic } & Wt\% NaNO $_{3}$ & $\begin{array}{c}\text { Specific Energy } \\
\text { (cal/g) }\end{array}$ & TNT Equivalent \\
\hline Carbon & 85 & 940 & 0.85 \\
\hline Carbon & 81 & 756 & 0.69 \\
\hline Carbon & 74 & 550 & 0.5 \\
\hline Carbon & 59 & 435 & 0.39 \\
\hline Carbon & 41 & 307 & 0.28 \\
\hline Carbon & 90 & 173 & 0.16 \\
\hline $\mathrm{C}_{10} \mathrm{H}_{22}$ & 88 & 1000 & 0.91 \\
\hline $\mathrm{C}_{10} \mathrm{H}_{22}$ & 92 & 333 & 0.30 \\
\hline $\mathrm{C}_{10} \mathrm{H}_{22}$ & 70 & 399 & 0.36 \\
\hline Styrene & 86 & 960 & 0.87 \\
\hline
\end{tabular}




\subsection{Scoping Tests}

The purpose of the bench-top testing (small quantities in open beakers) was to establish the general dryout characteristics of the waste simulant/reductant combinations and to identify candidate mixtures for subsequent pot calciner tests. Two types of scoping tests were performed:

1. Stoichiometric mixtures of the LAW simulant solution and reductant were boiled down in a series of beaker tests conducted in a fume hood. These mixtures were formulated theoretically to result in the complete conversion of nitrate to molecular nitrogen with no reductant left in the system. These tests provided a qualitative evaluation of how the reducing process would proceed starting with the liquid waste without any pretreatment.

2. Various waste simulant/reductant combinations were investigated to determine the magnitude of the exotherm produced. These tests were performed with $\sim 1-\mathrm{g}$ quantities of the mixtures (dry basis). The gram-size batches were heated to their reaction temperatures in $30-\mathrm{mL}$ beakers.

\subsubsection{Equipment and Test Methods}

The reaction temperatures of liquid simulant/reductant mixtures were measured with a thermocouple placed in contact with the bottom of the beaker while it was being heated on the hot plate. Typically about 50 to $100 \mathrm{~mL}$ of the mixture were boiled down in a $250-\mathrm{mL}$ beaker, and the changes of boiling and offgas behavior were recorded with time.

Further testing to investigate the magnitude of the exotherm achieved with various waste simulant/ reductant combinations was performed with $\sim 1-g$ quantities of the mixtures (dry basis). The gram-size batches were heated to their reaction temperatures in $30-\mathrm{mL}$ beakers, and the temperature was measured with a thermocouple in contact with the inside bottom of the beaker. The rate of reaction and temperature of initiation was noted.

Another approach to reducing the observed reaction rate was to dry the waste simulant to a crust layer in the pot calciner and heat to above the previously observed reaction temperatures. Through a port in the lid, small measured quantities of reductant (either as a solid or highly concentrated liquid) were placed on the preheated crust while offgas measurements were being made. Little or no reaction occurred between the waste simulant under these conditions. The offgases identified appeared to be thermal breakdown products of the respective reductants.

\subsubsection{Results and Discussion}

Table 5.2 summarizes the results of boildown tests using the acid simulant and pH-adjusted simulant with sugar or glycolic acid as the reductant. The table also includes the results of the smaller-scale tests run to gauge the rate of reaction.

The extensive $\mathrm{NO}_{\mathrm{x}}$ produced during the boildown of the liquid waste indicated that nitrous acid was a reduction product being formed. Under conditions of low $\mathrm{pH}(<6)$, the nitrous acid disproportionates. 
Table 5.2. Summary of Boildown Scoping Tests with LAW and Reductants

\begin{tabular}{|c|c|c|}
\hline Test Description & Max. Temp. & $\overline{\text { Results }}$ \\
\hline $\begin{array}{l}\text { Boildown of LAW Simulant with no } \\
\text { additives ( } 100 \mathrm{~mL}, 83 \mathrm{~min} \text { to dry) }\end{array}$ & $95^{\circ} \mathrm{C}$ & $\begin{array}{l}\text { Dried to a crystallized lime green crust. Some vapor was } \\
\text { observed. Absorbed water and turned bright yellow when } \\
\text { exposed to air after cooling. }\end{array}$ \\
\hline $\begin{array}{l}\text { Boildown of LAW Simulant + excess } \\
\text { glycolic acid ( } 100 \mathrm{~mL} \text {; run duration } \\
75 \mathrm{~min})\end{array}$ & $111^{\circ} \mathrm{C}$ & $\begin{array}{l}\text { Foamed excessively and turned bright green. Final product } \\
\text { was extremely viscous and adhesive. Significant quantities } \\
\text { of } \mathrm{NO}_{\mathrm{x}} \text { evolved. }\end{array}$ \\
\hline $\begin{array}{l}\text { Boildown of LAW Simulant + excess } \\
\text { sugar ( } 100 \mathrm{~mL} \text {; run duration } 87 \mathrm{~min})\end{array}$ & $>112^{\circ} \mathrm{C}$ & $\begin{array}{l}\text { Foamed excessively and turned dark brown/black with tan } \\
\text { foam on top. Foamed over the edge of the beaker. Inter- } \\
\text { mittent spikes of } \mathrm{NO}_{\mathrm{x}} \text { evolved. }\end{array}$ \\
\hline $\begin{array}{l}\text { Boildown of LAW Simulant }+ \\
\text { stoichiometric sugar ( } 100 \mathrm{~mL} \text {; run } \\
\text { duration } 53 \mathrm{~min})\end{array}$ & $346^{\circ} \mathrm{C}$ & $\begin{array}{l}\text { Foamed above top of beaker and ignited with an exothermic } \\
\text { reaction that started at } \sim 127^{\circ} \mathrm{C} \text {. Only black/gray ash left. } \\
\text { Significant quantities of } \mathrm{NO}_{x} \text { evolved. }\end{array}$ \\
\hline $\begin{array}{l}\text { Boildown of LAW Simulant }+ \\
\text { stoichiometric glycolic acid }(100 \mathrm{~mL} \\
\text { run duration } 61 \mathrm{~min})\end{array}$ & $214^{\circ} \mathrm{C}$ & $\begin{array}{l}\text { Foamed excessively and turned green. Residue was wet, } \\
\text { viscous, and adhesive. Significant quantities of } \mathrm{NO}_{\mathbf{x}} \\
\text { evolved. }\end{array}$ \\
\hline \multicolumn{3}{|c|}{ Boildown Tests With pH-Adjusted LAW Simulant } \\
\hline $\begin{array}{l}\text { Boildown of neutralized LAW Sim- } \\
\text { ulant + sugar ( } 50 \mathrm{~mL} \text {; run duration } \\
35 \mathrm{~min} \text { ) }\end{array}$ & $141^{\circ} \mathrm{C}$ & $\begin{array}{l}\text { One spark seen; beaker was removed from hot plate. Had } \\
\text { foamed to top of beaker as a yellow viscous and adhesive } \\
\text { liquid and burned blackish brown on the bottom. Signifi- } \\
\text { cant quantities of } \mathrm{NO}_{\mathrm{x}} \text { evolved. }\end{array}$ \\
\hline $\begin{array}{l}\text { Boildown of neutralized (pH 8.0) } \\
\text { LAW Simulant + Sugar ( } 50 \mathrm{~mL} \text {; run } \\
\text { duration } 26 \mathrm{~min})\end{array}$ & $224^{\circ} \mathrm{C}$ & $\begin{array}{l}\text { Yellow solid layer on top of charred layer. Some } \mathrm{NO}_{\mathbf{x}} \\
\text { observed at end of test. Charred layer slightly adhering. }\end{array}$ \\
\hline $\begin{array}{l}\text { Pot calciner offgas test of LAW } \\
\text { Simulant + sugar ( } 50 \mathrm{~mL} ; \text { run duration } \\
86 \mathrm{~min})\end{array}$ & $312^{\circ} \mathrm{C}$ & $\begin{array}{l}\text { Observed very energetic reaction. Only black ash left. } \\
\text { Reaction foamed excessively. Significant quantities of } \mathrm{NO}_{\mathrm{x}} \\
\text { evolved. }\end{array}$ \\
\hline \multicolumn{3}{|c|}{ Limited Quantity ( $\sim 1 \mathrm{~g}$ - dry basis) Tests for Observing the Rate of Reaction } \\
\hline $\begin{array}{l}\text { Boildown of neutralized LAW } \\
\text { Simulant + glycolic Acid ( } 2.06 \mathrm{~g} \text {; run } \\
\text { duration } 18 \mathrm{~min})\end{array}$ & $240^{\circ} \mathrm{C}$ & $\begin{array}{l}\text { Observed very energetic reaction at about } 220^{\circ} \mathrm{C} \text {. } \mathrm{NO}_{\mathrm{x}} \\
\text { observed. }\end{array}$ \\
\hline $\begin{array}{l}\text { Boildown of neutralized LAW } \\
\text { Simulant }+ \text { sugar }(0.77 \mathrm{~g} ; \text { run duration } \\
11 \mathrm{~min})\end{array}$ & $\sim 250^{\circ} \mathrm{C}$ & $\begin{array}{l}\text { Observed very energetic reaction at about } 165^{\circ} \mathrm{C} . \mathrm{NO}_{\mathbf{x}} \\
\text { observed. }\end{array}$ \\
\hline $\begin{array}{l}\text { Dried neutralized LAW Simulant + } \\
\text { various reductants }\end{array}$ & $335^{\circ} \mathrm{C}$ & $\begin{array}{l}\text { Neutralized LAW Simulant without reductant dried without } \\
\text { any problems. Turned beige and cracked as it dried. Is } \\
\text { very hygroscopic. Some } \mathrm{NO}_{\mathrm{x}} \text { evolved. } \\
\text { charcoal-no reaction } \\
\text { sugar-rapid reaction + light } \\
\text { carbon-no reaction } \\
\text { paper-decomposed without reacting } \\
\text { corn starch-rapid reaction with some smoke } \\
\text { glycolic acid-rapid reaction + light } \\
\text { acetic acid-no apparent reaction after boiling to dryness }\end{array}$ \\
\hline
\end{tabular}


Increasing the simulant $\mathrm{pH}$ to $\sim 6$ by $\mathrm{Ca}(\mathrm{OH})_{2}$ additions produced a waste simulant/reductant combination that could be dried without $\mathrm{NO}_{\mathrm{x}}$ generation. These solids were observed to be very hygroscopic and rapidly reliquefied when left exposed to humid air. When the LAW simulant $\mathrm{pH}$ was adjusted only to 1.0, the boildown testing results were quite similar to test results for acidic LAW simulant plus reductant. Two tests with excess reductant foamed excessively and produced $\mathrm{NO}_{\mathrm{x}}$. Tests using LAW simulant + stoichiometric sugar displayed similar results, i.e., foaming with $\mathrm{NO}_{\mathrm{x}}$ generation. When these tests were taken to higher temperature, a strongly exothermic reaction was observed with sugar but not with glycolic acid. An exotherm apparently caused the higher maximum temperature for the test containing stoichiometric sugar. The equivalent glycolic acid test was terminated before an exotherm was observed because it was producing large quantities of $\mathrm{NO}_{\mathbf{x}}$.

Several small-scale scoping tests, performed with 1-g quantities of the pH-adjusted LAW to which reductant was added, showed that the reaction occurred very rapidly. Hence, an approach was investigated for diluting the waste to moderate the reaction rate, rather than going to larger-scale testing with those mixtures.

The results of these scoping tests showed that a reaction retardant was needed to run the denitration reaction in a batch mode. It is known that finely divided inert material is mixed with black powder to make it burn slowly for fuse applications. Micro-Cel $\mathrm{E}$ was chosen for this application because of its liquid absorbing capacity and chemical compatibility with grout.

The acid nature of the LAW also made it difficult to dry the waste without producing excessive $\mathrm{NO}_{\mathrm{x}}$. As discussed in Section 4.0, distillation is proposed as a way to remove the acid nitrate, leaving the hazardous waste components in the distillation "bottoms." Further reductant denitration testing was performed with LAW bottoms simulant.

\subsection{Reaction Calorimetry Testing}

Reaction calorimetry tests were run to quantify reaction onset temperatures and the rates and energies of reactions. These tests confirmed the behavior exhibited by the LAW evaporator bottoms simulant and reductants observed during the bench-scale rotary calciner. In general, for most of the reaction calorimetry tests, two exothermic reactions occurred at around $100^{\circ} \mathrm{C}$ and $250^{\circ} \mathrm{C}$, releasing a total of about 1000 to $1400 \mathrm{~J} / \mathrm{g}$ at a controllable rate.

\subsubsection{Equipment-Calvet Calorimeter}

Heats of combustion were measured using a SETARAM/SFIM (France) C 80 II Calvet calorimeter. Calvet calorimeters operate with two identical cylindrical measurement cells placed in a temperaturecontrolled block. One of these cells serves as a reference, and the other contains the material being reacted.

The cells are surrounded by and thermally coupled to the calorimetric block by two sets of thermopiles connected in opposition (a thermopile being a large number of thermocouples connected in series). Under a steady-state condition, and in the absence of a heat-producing reaction in the sample cell, the 
voltage in the thermopiles cancels and a baseline power output is observed-effectively zero under ideal circumstances. Conversely, a reaction occurring in the sample cell produces or consumes heat, causing a small but finite change in the cell temperature. The change in temperature produces a voltage in the sample cell thermopile that is sensed and countered by a corresponding increase or decrease in the power output to the heater as necessary to re-acquire the steady-state condition. This power is measured and is equivalent, but opposite in sign, to the power produced by the reaction occurring in the sample cell. The amount of energy produced by the reaction is determined by integration with respect to the time required to re-acquire the baseline power. Presuming the mass and identity of the reacting material are known, the reaction/combustion heat can then be reported in terms of $\mathrm{J} / \mathrm{g}$ or $\mathrm{J} / \mathrm{mole}$.

The cells used in the experiments were approximately $7.0 \mathrm{~cm}$ long and $1.8 \mathrm{~cm}$ wide, with a volume of approximately $12 \mathrm{~cm}^{3}$, and were connected to the exterior of the calorimeter by $29-\mathrm{cm}$ tubes (3-mm ID), which were sealed at the top. The volume of the tubes can be a source of error in the measurement of the combustion heats, as some heat may be conducted away from the sensitive zone of the calorimeter. To minimize this effect, filler rods were inserted into the tubes in a number of the experiments, although this also can introduce error through loss of heat through conduction. The rods also seemed to introduce noise, presumably because the rods slipped downward as the solid material on which they rested reacted.

Experiments were run in "scanning" mode where the temperature was slowly increased at a fixed rate. The rate chosen for most tests was $0.1^{\circ} \mathrm{C} / \mathrm{min}$. The onset temperature for the reaction of a particular sample was found to be dependent on heating rate; multiple reactions occurred within single samples, and, in some cases, successive reactions seem to have occurred before complete dissipation of heat from earlier reactions. Consequently, it may be difficult to identify heats for individual reactions in a stepwise combustion process. In addition, calorimetric measurements under very fast heating rates may erroneously ascribe reaction heats from multiple reaction steps to a single reaction.

\subsubsection{Test Methods and Conditions}

The calorimetry tests were performed using the standard LAW evaporation bottoms simulant, with two different reductants and two different inert additives (Micro-Cel $\mathrm{E}$ and flyash). The reductants, sucrose and glycolic acid, were tested at different reductant-to-simulant stoichiometric ratios. Table 5.3 (in Section 5.3.3) summarizes the test conditions.

The simulated LAW evaporator bottoms (wet slurry) were mixed with the predetermined quantity of reductant and diluent, and the slurry was well mixed, then dried under vacuum at $40^{\circ} \mathrm{C}$ until a constant weight was obtained. Even at this low drying temperature $\left(40^{\circ} \mathrm{C}\right)$ it was apparent that some reaction was occurring, as evidenced by the distinct $\mathrm{NO}_{2}$ odor that could be detected above the dried samples. Because of this pre-reaction during drying, the total reaction energies associated with the reductant/nitrate reactions determined from the reaction calorimeter may have been slightly underestimated.

Each calorimetry test was conducted with 200 to $600 \mathrm{mg}$ of total sample (simulant + reductant + inert). In the reaction calorimeter, the test material was heated at a rate of $0.1^{\circ} \mathrm{C} / \mathrm{min}$. Filler rods were placed in the reference cell and the sample cell during Runs 1a, 5a, and 5b. All other runs were conducted without the filler rods because of the problems noted earlier. 


\subsubsection{Results and Discussion}

Table 5.3 presents the results of the reaction calorimetry testing, including onset and peak temperature for each exotherm and energy associated with each exotherm. The relative percent differences (RPDs) of the total reaction energy are also provided for the tests in which duplicate reaction calorimetry runs were conducted. Appendix $E$ includes the complete calorimetry plots for each run.

For the three runs conducted in duplicate, RPDs between $8 \%$ and $23 \%$ were obtained. These RPDs indicate that the results are reasonably reproducible, especially considering that the physical appearance of the samples indicated they were not completely homogeneous.

In the tests conducted with sucrose and Micro-Cel E, the stoichiometric ratio of sucrose to nitrate $(0.75,1$, and 1.25:1) did not have a significant effect on temperatures or energies associated with the exothermic reactions. The first reaction onset temperatures occurred at $110^{\circ} \mathrm{C}$ to $130^{\circ} \mathrm{C}$ and released $330^{\circ} \mathrm{C}$ to $610 \mathrm{~J} / \mathrm{g}$, while the second reaction occurred at $230^{\circ} \mathrm{C}$ to $260^{\circ} \mathrm{C}$ and released $680^{\circ} \mathrm{C}$ to $860 \mathrm{~J} / \mathrm{g}$, releasing a total of 1060 to $1400 \mathrm{~J} / \mathrm{g}$. Based on observations, it appears that the primary combustion reaction is occurring at the higher-temperature exotherm. The sample was not observed to turn brown until $\sim 245^{\circ} \mathrm{C}$.

For the sucrose-Micro-Cel E tests, the difference between the onset and peak temperatures was much smaller for the second exotherm $\left(0\right.$ to $\left.3^{\circ} \mathrm{C}\right)$ compared to the first $\left(4^{\circ} \mathrm{C}\right.$ to $\left.9^{\circ} \mathrm{C}\right)$. While the reactions were energetic, only one occurred rapidly enough to be classified as an ignition, or rapid self-sustaining reaction, i.e., the second exotherm in Run 3 (sucrose:nitrate $=1.25: 1$ ).

When Micro-Cel E was removed from the mixture containing sucrose (Runs $5 \mathrm{a}$ and $5 \mathrm{~b}$ ), the onset temperatures for both exothermic reactions decreased by about $50^{\circ} \mathrm{C}$. This indicates that Micro-Cel $\mathrm{E}$ is effective in producing a more predictable and stable mixture. That is, with a sucrose:nitrate at $1: 1$, with no inert additive, the onset temperature for the first exothermic reaction was as low as $75^{\circ} \mathrm{C}$ with $\sim 440 \mathrm{~J} / \mathrm{g}$ being produced.

In Run 6, flyash was used as the additive material at a sucrose:nitrate ratio of 1:1. The first exotherm was very similar to that produced when no inert was added (Runs $5 \mathrm{a}$ and $5 \mathrm{~b}$ ). The onset temperature was $82^{\circ} \mathrm{C}$, and the exotherm was $380 \mathrm{~J} / \mathrm{g}$. However, for this run, no distinct second exotherm was generated. Examination of the calorimetry plot (Appendix E) shows that after the first exotherm, a second, small exotherm followed $(65 \mathrm{~J} / \mathrm{g})$, and then the baseline drifted upwards for the duration of the test. After this test was conducted, it was observed that the product had formed a hard, black ball inside the cell.

With glycolic acid as the reductant (Run 4), very broad exotherms were obtained (i.e., large relative difference between onset and peak temperatures). Additionally, this run resulted in a third, smaller, exotherm (114 J/g) between two larger exotherms. The total energy for the exotherms was similar to that produced when using sucrose as the reductant. Comparing Run 4 with Run 1 shows that the exothermic reaction rates associated with glycolic addition appear to be substantially lower than those obtained under similar conditions with sucrose. However, the onset temperatures are $\sim 25^{\circ} \mathrm{C}$ lower with glycolic acid. 


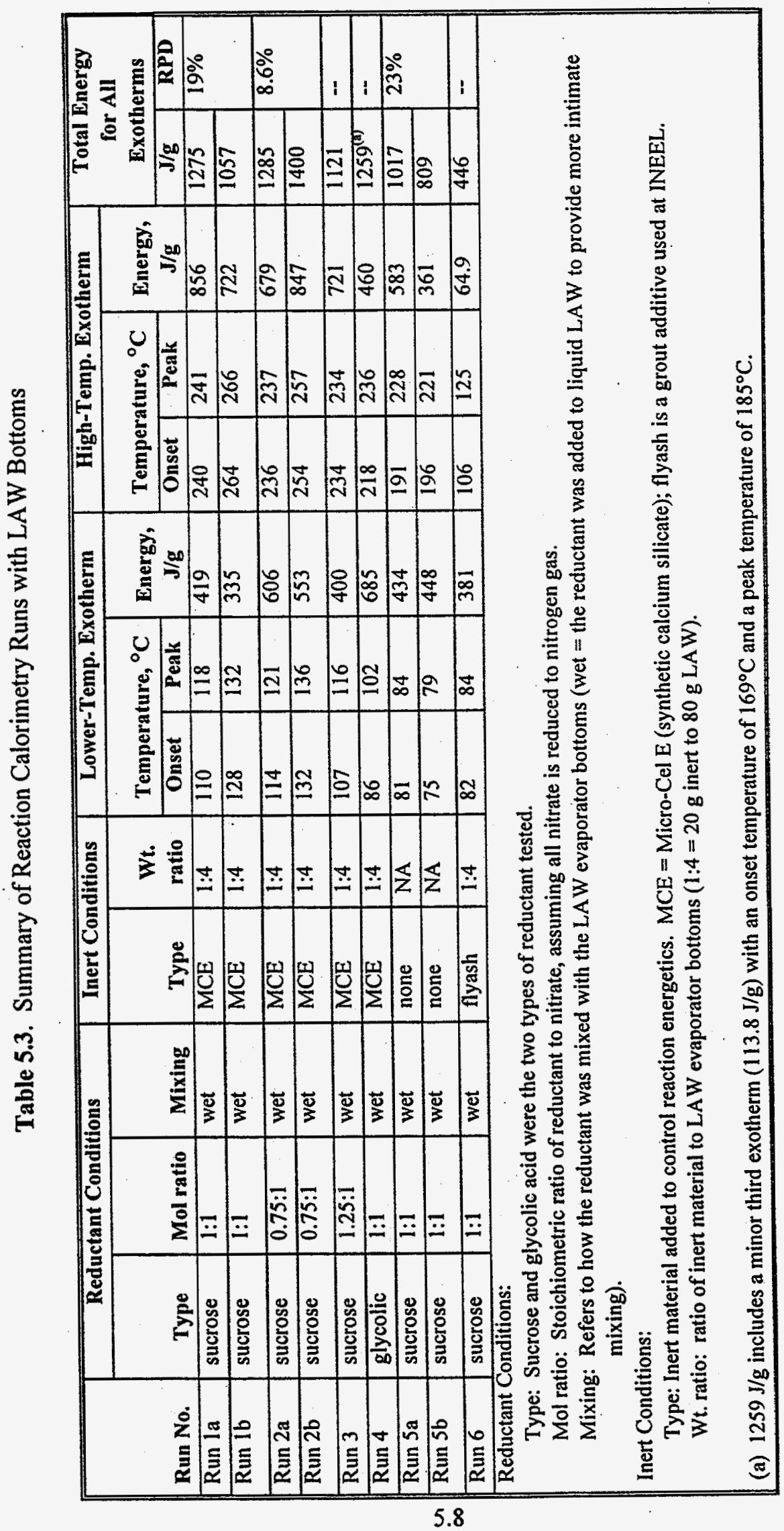


The implication from the comparison is that the use of glycolic acid may result in more controllable (slower) reactions; however, LAW mixed with glycolic acid is less stable at lower temperatures.

The current experimental data indicate that the nitrate/reductant reaction rates and energies can be safely managed using commercially available equipment. [As a point of reference, the energy content of coal is 30,000 to $35,000 \mathrm{~J} / \mathrm{g}$.] However, the temperature ramp profile in a commercial calciner will be much more compressed than the $0.1^{\circ} \mathrm{C} / \mathrm{min}$ used in the reaction calorimeter. Consequently, the multiple exotherms would likely be compressed into a single event. Testing with a continuous prototypical calciner system will more fully assess the reaction behaviors in a commercial system.

\subsection{Pot Calciner (With Offgas Analysis)}

Pot calciner tests were performed to define reductant/waste simulant combinations that could be controlled in bench-scale calciner studies. For these tests, Micro-Cel $\mathrm{E}$ was added to the mixture as the reaction retardant.

\subsubsection{Equipment}

The laboratory pot calciner (Figure 5.1) consists of a 2-L Pyrex kettle heated by a temperaturecontrolled heating mantle also used for the boildown tests. The kettle lid is modified to accept several

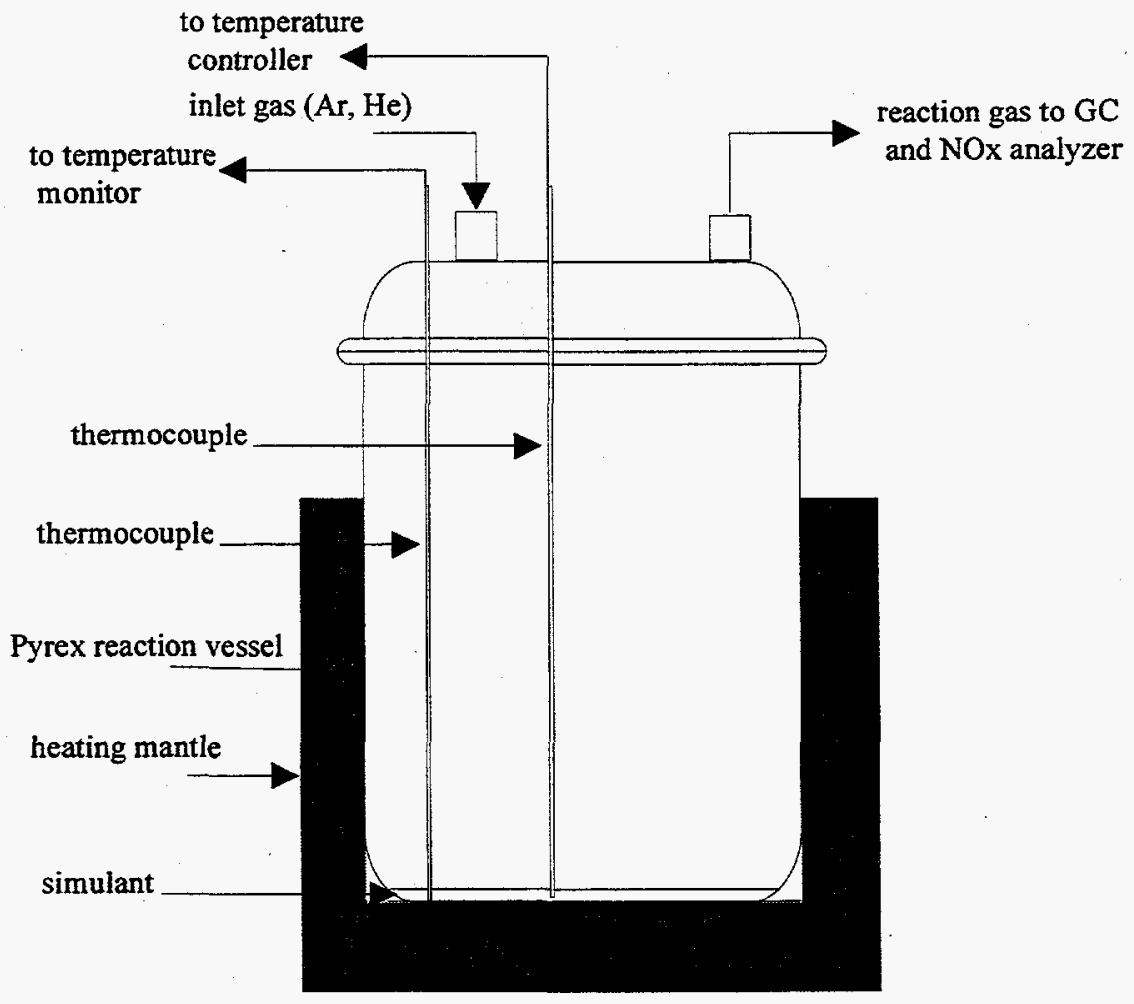

Figure 5.1. Pot Calciner Setup 
thermocouples, condensers, and sweep gas inlets. The sweep gases (argon and helium tracer) carry offgas from the reaction vessel plenum through the condensers to the offgas analysis system. Multiple thermocouples may be placed in the reaction vessel to detect temperature gradients in the calcine.

Real-time offgas monitoring was used to characterize the offgas composition. A gas chromatograph (GC) monitored the generation rates of the major gaseous reaction products: $\mathrm{H}_{2}, \mathrm{CO}_{2}, \mathrm{~N}_{2} \mathrm{O}, \mathrm{NO}$, and $\mathrm{N}_{2}$. Reliable $\mathrm{CO}$ measurements were not obtained during these tests. A chemiluminescent $\mathrm{NO} / \mathrm{NO}_{\mathrm{x}}$ analyzer was used to measure $\mathrm{NO}_{\mathrm{x}}$.

\subsubsection{Test Methods and Conditions}

The objective of these tests was to document the low-temperature calcination of the LAW bottoms containing $50 \%$ to $75 \%$ of the stoichiometric amount of sugar or glycolic acid absorbed on Micro-Cel E. The low stoichiometry was chosen to reduce the exothermic reaction intensity. The low stoichiometry also allowed the reaction chemistry to be investigated in this range as a start to establishing the acceptable range of the reductant to nitrate ratio. It was expected that the reaction chemistry would be less reducing and, therefore, nitrogen oxides such as $\mathrm{NO}$ and $\mathrm{N}_{2} \mathrm{O}$ would be much more prevalent than under ratios closer to 1 .

The test was set up as shown in Figure 5.1. The simulant used for these tests was the LAW bottoms composition given in Table 3.1, concentrated by a factor of 3.3. This waste simulant contained 0.00429 moles of nitrate per gram. Offgas measurements as a function of time provided the primary data. LAW bottom simulant was mixed with Micro-Cel $\mathrm{E}$ in a paste-like mixture in the ratios given in Table 5.4. The reductant was added and thoroughly mixed so that a homogeneous mixture resulted. The test material was placed in a 2-L reaction vessel in a heating mantle and connected to the offgas measuring system. The reaction vessel was heated to $100^{\circ} \mathrm{C}$ and allowed to equilibrate. After the simulant had equilibrated, the setpoint was increased to $20^{\circ} \mathrm{C}$ above the control thermocouple reading. This mode was continued until the temperature reached $400^{\circ} \mathrm{C}$. Typically, a $\sim 5^{\circ} \mathrm{C}$ per minute temperature rise was observed unless an exothermic reaction occurred. After $\sim 400^{\circ} \mathrm{C}$, the system was allowed to cool while still measuring offgas. Temperature profiles are shown in Figures 5.2 through 5.5.

Table 5.4. Initial Test Conditions

\begin{tabular}{||l|c|c|c|c|c||}
\hline Test & $\begin{array}{c}\text { Initial Test } \\
\text { Weight (ITW) }\end{array}$ & $\begin{array}{c}\text { Moles } \\
\text { Nitrate }\end{array}$ & $\begin{array}{c}\text { Moles } \\
\text { Reductant } \\
\text { added to ITW }\end{array}$ & $\begin{array}{c}\text { Stoichiometric }^{(\text {a) }} \\
\text { Moles Reductant }\end{array}$ & $\begin{array}{c}\text { \% of } \\
\text { Stoichiometry }^{\text {Mdrach }}\end{array}$ \\
\hline $3: 1 \mathrm{G}$ & $16 \mathrm{~g}$ & 0.0513 & 0.0258 & 0.0513 & 50.3 \\
\hline $4: 1 \mathrm{~S}$ & $\mathbf{8 . 8 \mathrm { g }}$ & 0.0301 & 0.00175 & 0.00376 & 46.5 \\
\hline $4: 1 \mathrm{Sa}$ & $10 \mathrm{~g}$ & 0.0342 & 0.0024 & 0.00428 & 56.1 \\
\hline $4: 1 \mathrm{Ga}$ & $10 \mathrm{~g}$ & 0.0342 & 0.0258 & 0.0342 & 75.4 \\
\hline
\end{tabular}

(a) Note: Stoichiometry for sugar (sucrose) (S)-nitrate was assumed to be 1 mole sugar to 8 moles nitrate; for the glycolic acid $(G)$, it was 1 mole acid to 1 mole nitrate. 


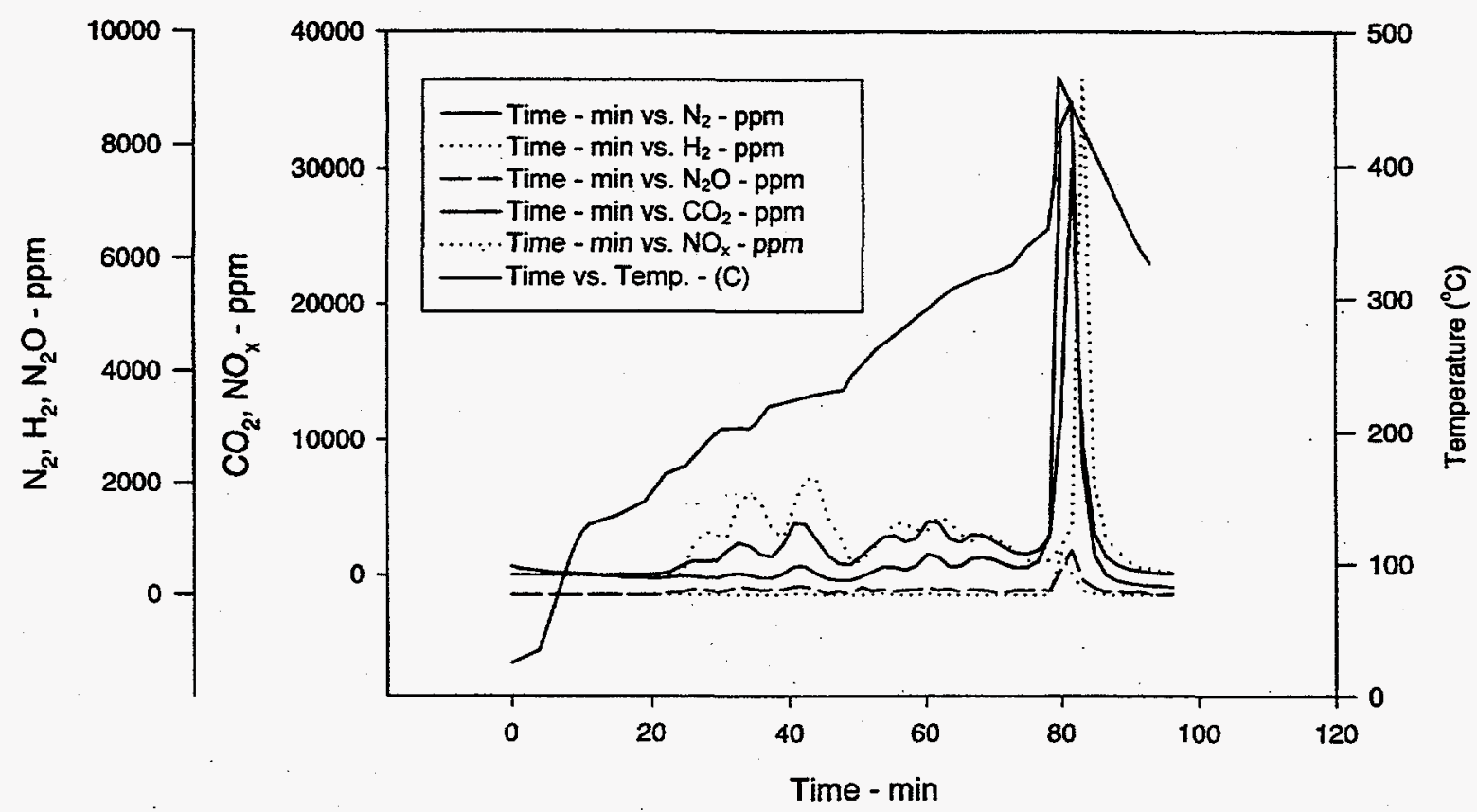

Figure 5.2. Offgas Generation Profile for Test 3:1G. The peak corresponds to the exotherm for that test.

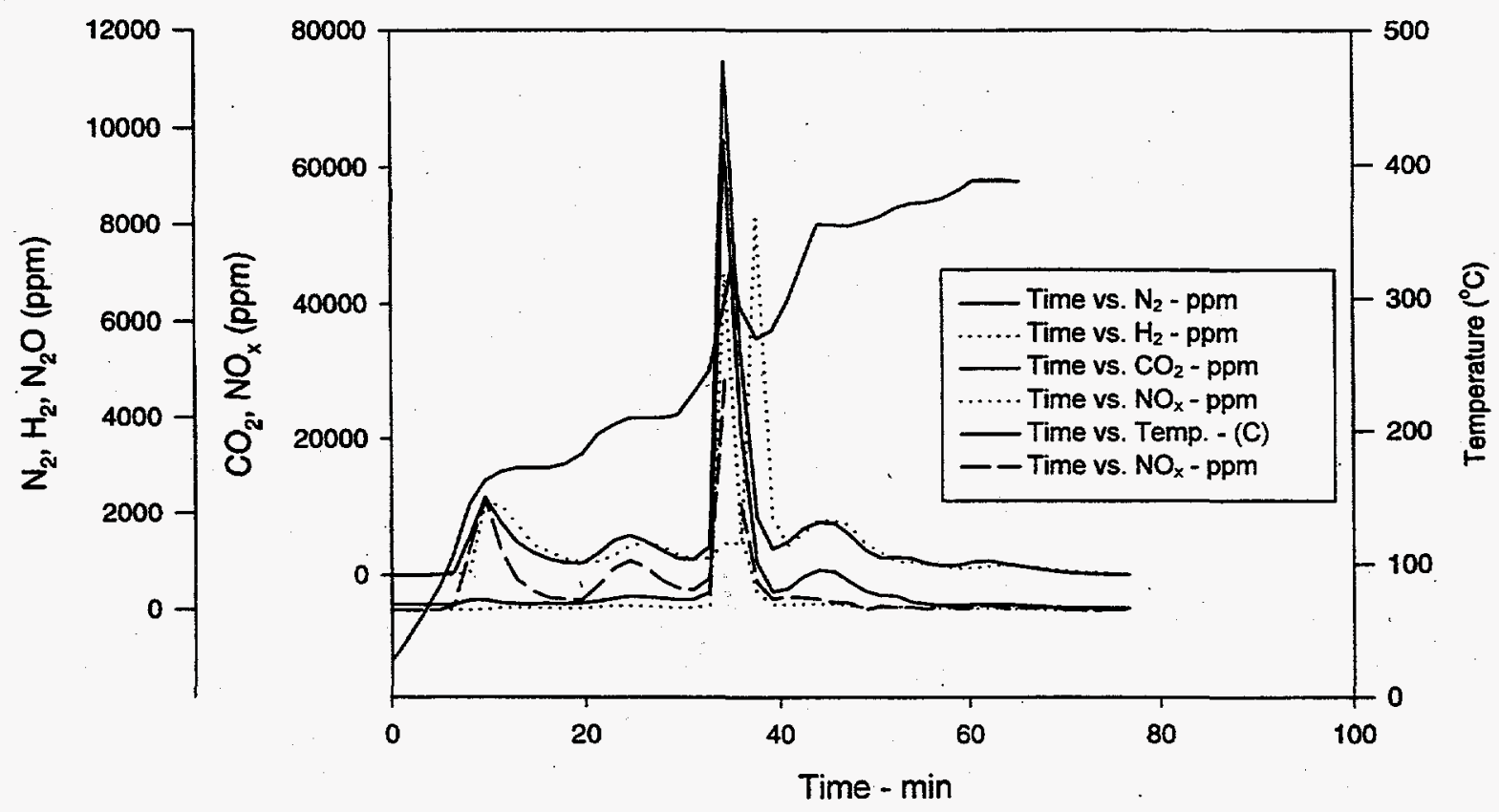

Figure 5.3. Offgas Generation Profile for Test 4:1S. The peak corresponds to the exotherm for that test. 


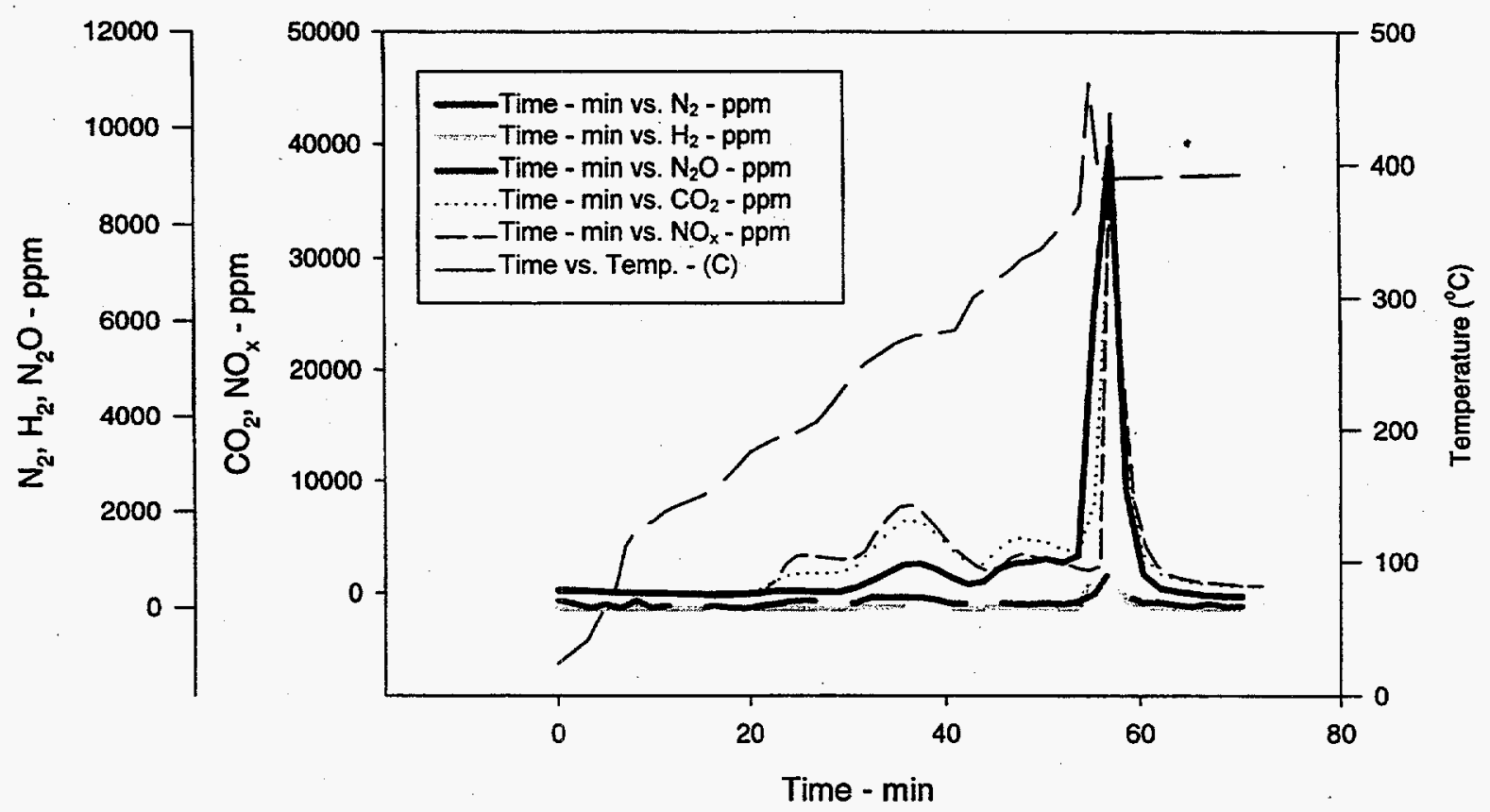

Figure 5.4. Offgas Generation Profile for Test 4:1Sa. The peak corresponds to the exotherm for that test.

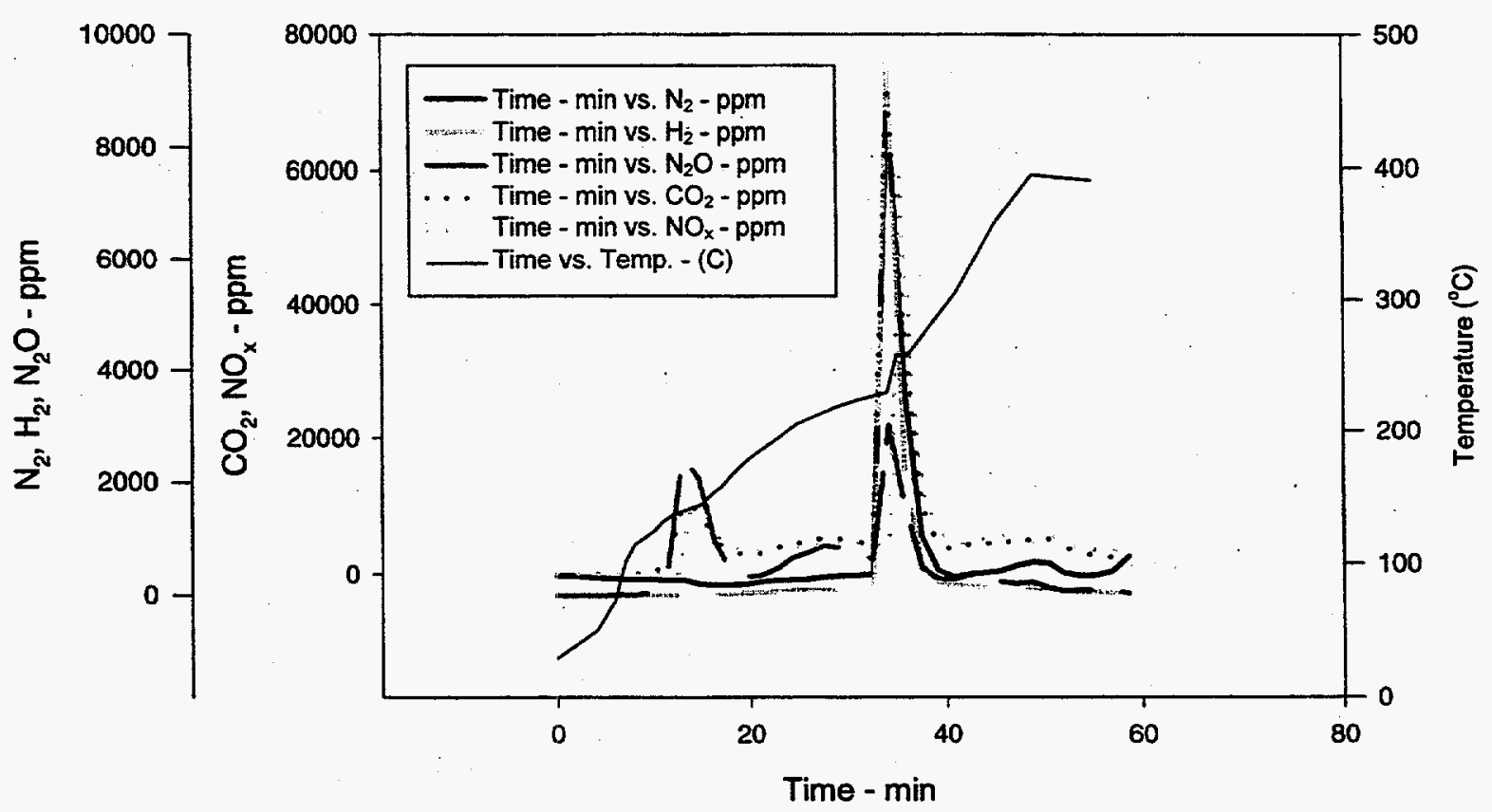

Figure 5.5. Offgas Generation Profile for Test 4:1Ga. The peak corresponds to the exotherm for that test. 
Previous laboratory scoping test experience with these combinations suggested that by adding a reaction retardant there would be no uncontrollable energy release. Consequently, the gas release from the expected reaction was estimated to be $\sim 1 \mathrm{~L}$ of gas (standard temperature and pressure) [0.0171 moles of nitrogen, 0.0288 moles of carbon dioxide; 0.035 moles of water will condense in the condenser]. This would cause a pressurization of the reaction vessel of less than $10 \mathrm{psig}$ if the vessel were completely sealed and the reaction fast. However, for this testing, the reaction vessel was vented through the offgas port, and the other ports on the vessel lid opened at an overpressure of 1 to 2 psig. Hence, no significant pressurization of the vessel occurred or was expected. However, as a precaution, the tests were run in a hood with the sash in a lowered position.

\subsubsection{Results and Discussion}

The results are summarized in Tables 5.5 and 5.6 and in Figures 5.2 through 5.5. These reductant/ nitrate ratios produced mole fractions of nitrogen and nitrogen oxides that were significantly different than had been experienced for similar materials at 100\% stoichiometric ratios (see Smith et al. 1996). The expected ratio of $\mathrm{N}_{2}: \mathrm{NO}_{\mathrm{x}}$ for $100 \%$ stoichiometric ratios of nitrate to reductant is better than 2:1 (note that this is a 4:1 atom ratio). For these tests, the ratio was 1:4 for sugar at $\sim 50 \%, 1: 5$ for glycolic acid at $50 \%$, and 1:6 for glycolic acid at 75\% (see Table 5.6). Though these ratios were different from the $100 \%$ case, they shifted in the direction that was more oxidized.

All of the test materials were analyzed for nitrate and total carbon plus total organic carbon (TOC) after the tests. These analyses indicated that a significant percentage of the nitrate remained but very little carbon remained in the calcine. If the organic was completely destroyed by a combination of the denitration reactions and thermal composition, this would explain why additional nitrate destruction did not occur in these tests as indicated by the dropping gas generation rates (Figures 5.2 through 5.5). The analytical precision was believed to be low $( \pm 20 \%)$ for the nitrate because simulant and precalcined materials did not agree closely. Hence, percent nitrate destroyed could not be calculated quantitatively (the difference of two large numbers). The efficiency of nitrate destruction for these tests (see Table 5.6) was therefore calculated in two different ways: the first method was based on the change in nitrate concentration of the starting material compared to the post-reaction material (an approximate number); the second method was based on an estimate of the amount of each nitrogen-containing offgas component released during the exothermal event. The offgas results appear to be in qualitative agreement with analytical results.

The limited agreement between the two methods suggests problems should be more fully resolved. The source of the discrepancy may lie in the sample retrieved after each test. It was observed that the gases released during the exothermic reaction caused much of the upper layer of material to become airborne. This material would then have contained unreacted nitrate, which might account for the higherthan-expected nitrate levels in the after-test material. During earlier denitration studies by Smith et al. (1996), the reacting materials were in a pellet or a salt cake form. When these materials were heat treated in the same way, they displayed a strong exothermic reaction and copious amounts of gas were generated; little if any material became airborne. Additional tests using similar conditioning would allow the reaction to proceed in a more uniform manner to completion. 
Table 5.5. Exotherm Initiation Temperatures and Peak Observed Temperatures

\begin{tabular}{|c|c|c|}
\hline Test & Exotherm Initiation Temp. $\left({ }^{\circ} \mathbf{C}\right)$ & Peak Temp. $\left({ }^{\circ} \mathbf{C}\right)$ \\
\hline $3: 1 \mathrm{G}$ & 249 & 324 \\
\hline $4: 1 \mathrm{~S}$ & 390 & 466 \\
\hline $4: 1 \mathrm{Sa}$ & 370 & 461 \\
\hline $4: 1 \mathrm{Ga}$ & 229 & 258 \\
\hline
\end{tabular}

Table 5.6. Peak Sweep Gas Concentrations of Offgas from Denitration Reactions

\begin{tabular}{|c|c|c|c|c|c|c|c|c|c|}
\hline Test & $\begin{array}{c}\% \text { of } \\
\text { Stoichio- } \\
\text { metry }\end{array}$ & $\begin{array}{c}\% \text { Nitrate } \\
\text { Destroyed } \\
\text { (calc-offgas) }\end{array}$ & $\begin{array}{c}\mathrm{N}_{2} \text { as a } \\
\% \text { of } \\
\text { Nitrate }\end{array}$ & $\begin{array}{l}\text { Efficiency } \\
\% \text { of Stoi. }\end{array}$ & $\begin{array}{c}\mathrm{N}_{2} \\
(\mathrm{ppm}) \\
\text { per } \mathrm{g} \\
\mathrm{ITW} \\
\end{array}$ & $\begin{array}{c}\mathrm{NO}_{\mathbf{x}} \\
(\mathrm{ppm}) \\
\text { per g } \\
\text { ITW }\end{array}$ & $\begin{array}{c}\mathrm{N}_{2} \mathrm{O} \\
(\mathrm{ppm}) \\
\text { per } \mathrm{g} \\
\mathrm{ITW}\end{array}$ & $\begin{array}{c}\mathbf{H}_{2} \\
(\mathrm{ppm}) \\
\text { per } \mathrm{g} \\
\text { ITW }\end{array}$ & $\begin{array}{c}\mathrm{CO}_{2} \\
\text { (ppm) } \\
\text { per } \\
\text { g ITW }\end{array}$ \\
\hline $3: 1 \mathrm{G}$ & 50.3 & $55.6(58.9)$ & 9.0 & 17.9 & 609 & 3286 & 298 & 437 & 4716 \\
\hline $4: 1 \mathrm{~S}$ & 46.5 & $61.3(91.5)$ & 22.8 & 49.0 & 997 & 4159 & 91 & 85 & 3410 \\
\hline $4: 1 \mathrm{Sa}$ & 56.1 & $57.5(72.5)$ & 20.7 & 36.9 & 961 & 4275 & 79 & 70 & 3448 \\
\hline $4: 1 \mathrm{Ga}$ & 75.4 & $67.2(88.2)$ & 12.8 & 17.0 & 895 & 5916 & 301 & $\overline{933}$ & 7262 \\
\hline
\end{tabular}

The exotherm initiation temperatures and peak observed temperatures (Table 5.5) give the temperature at which the exothermic reaction was first recognized and the maximum temperature reached while the exothermic reaction was in progress. The actual initiation temperature is probably $10^{\circ} \mathrm{C}$ to $20^{\circ} \mathrm{C}$ lower than that given in Table 5.5. The results show consistency. The exothermic reaction initiation temperatures for sugar-LAW and glycolic acid-LAW are similar for approximately replicate tests. Figures 5.2 through 5.5 show the gas generation profiles associated with the temperature profiles imposed on each test; Table 5.6 gives the scaled (normalized to a per gram basis) amounts of nitrogen along with the other gases observed.

In terms of the sugar/nitrate reaction (Equations 5.5 to 5.9), it is observed that 3 moles of $\mathrm{CO}_{2}$ are generated for every mole of $\mathrm{N}_{2}$ generated under conditions of excess nitrate (Equation 5.8). From the results shown in Table 5.6 for sugar, the ratio is on the order of 3.5. This suggests, under the test conditions, there was also thermal decomposition of the sugar, which is consistent with the presence of hydrogen in the offgas and would have generated additional $\mathrm{CO}_{2}$. The presence of significant $\mathrm{NO}$ suggests that the nitrate was also thermally decomposed. It could also be a result of excess nitrate as suggested by Equation (5.8).

$$
\begin{gathered}
\mathrm{C}_{12} \mathrm{H}_{22} \mathrm{O}_{11}+8 \mathrm{NaNO}_{3} \longleftrightarrow 4 \mathrm{Na}_{2} \mathrm{O}+4 \mathrm{~N}_{2} \uparrow+8 \mathrm{CO}_{2} \uparrow+4 \mathrm{CO} \uparrow+11 \mathrm{H}_{2} \mathrm{O} \uparrow \\
\mathrm{C}_{12} \mathrm{H}_{22} \mathrm{O}_{11}+9 \mathrm{NaNO}_{3} \longleftrightarrow 4.5 \mathrm{Na}_{2} \mathrm{O}+4.5 \mathrm{~N}_{2} \uparrow+11 \mathrm{CO}_{2} \uparrow+\mathrm{CO} \uparrow+11 \mathrm{H}_{2} \mathrm{O} \uparrow \\
\mathrm{C}_{12} \mathrm{H}_{22} \mathrm{O}_{11}+10 \mathrm{NaNO}_{3} \longleftrightarrow 5 \mathrm{Na}_{2} \mathrm{O}+4 \mathrm{~N}_{2} \uparrow+12 \mathrm{CO}_{2} \uparrow+\mathrm{N}_{2} \mathrm{O} \uparrow+11 \mathrm{H}_{2} \mathrm{O} \uparrow \\
\mathrm{C}_{12} \mathrm{H}_{22} \mathrm{O}_{11}+11 \mathrm{NaNO}_{3} \longleftrightarrow 5 \mathrm{Na}_{2} \mathrm{O}+3 \mathrm{~N}_{2} \uparrow+12 \mathrm{CO}_{2} \uparrow+3 \mathrm{NO} \uparrow+\mathrm{N}_{2} \mathrm{O} \uparrow+11 \mathrm{H}_{2} \mathrm{O} \uparrow
\end{gathered}
$$


For glycolic acid, the reaction with excess nitrate could be

$$
3 \mathrm{C}_{2} \mathrm{H}_{4} \mathrm{O}_{3}+4 \mathrm{NaNO}_{3} \longleftrightarrow \mathrm{N}_{2} \uparrow+6 \mathrm{H}_{2} \mathrm{O} \uparrow+6 \mathrm{CO}_{2} \uparrow+2 \mathrm{Na}_{2} \mathrm{O}+\mathrm{N}_{2} \mathrm{O} \uparrow
$$

In this case, the ratio of nitrogen gas to $\mathrm{CO}_{2}$ would be 6 . For the tests, it was observed to be about 8 . This is consistent with the results for sugar, where thermal decomposition of the organic would have generated additional $\mathrm{CO}_{2}$ and thermal decomposition of the nitrate would generate NO.

These tests indicated sugar is a more effective reductant than glycolic acid for the reduction of nitrate to nitrogen. The reactions written above coupled with thermal decomposition (not shown but discussed in Appendix A) appear to give a reasonable description of the reactions that occurred during these tests. The very loose packing of the waste simulant/reductant mixture for these tests may have caused the inefficient denitration, i.e., the production of $\mathrm{NO}_{\mathrm{x}}$ and $\mathrm{H}_{2}$ due to thermal decomposition of the reductant and the nitrate. Tests with the waste simulant/reductant mixture in a pelletized form would provide a better basis for understanding the reactions.

\subsection{Bench-Scale Rotary Calciner}

Calciner tests were performed in a small, bench-scale rotary calciner to observe and quantify the physical behavior of denitration mixtures and the offgas characteristics of the mixtures on the system during and after calcination, as well as the dynamics of the denitration technique, in a form that would be applicable to pilot- and full-scale systems.

\subsubsection{Equipment}

The experiments were conducted with a bench-scale calciner that included offgas analysis equipment. The calciner consisted of a 4-in.-diameter quartz reactor held between two non-rotating, stainless steel pillow blocks. The quartz reactor had from three to nine dimples, approximately 1 in. in diameter and $1 / 2$ in. deep, that were used as mixing flights when the unit was operating. The quartz reactor was surrounded by a 1-zone clamshell heater that had insulating collars where the reactor arms extended from either side of the heater. An overhead picture of the unit is shown in Figure 5.6, and a schematic is shown in Figure 5.7.

Pillow blocks were fitted with ground glass ball-joints that were greased and held together with spring clamps to maintain a gas-tight seal while still allowing the reactor to rotate. A direct chain drive was used to rotate the reactor at about $4 \mathrm{rpm}$. The outlet arm of the reactor was also packed with quartz wool to keep fine particulates from exiting the reaction chamber.

The front pillow block was fitted with a type-K thermocouple that extended into the center of the reactor and was bent down to drag in the calcined material as the reactor rotated. The block was also fitted with a magnahelic pressure gauge and an inlet for the sweep gas. The rear pillow block was assembled with a magnahelic, a particulate filter on the gas exit line, and a large-diameter blowdown tube submerged in $4 \mathrm{in}$. of water to allow excess gas to be collected if the reactor exceeded $4 \mathrm{in}$. of water pressure during operation. 


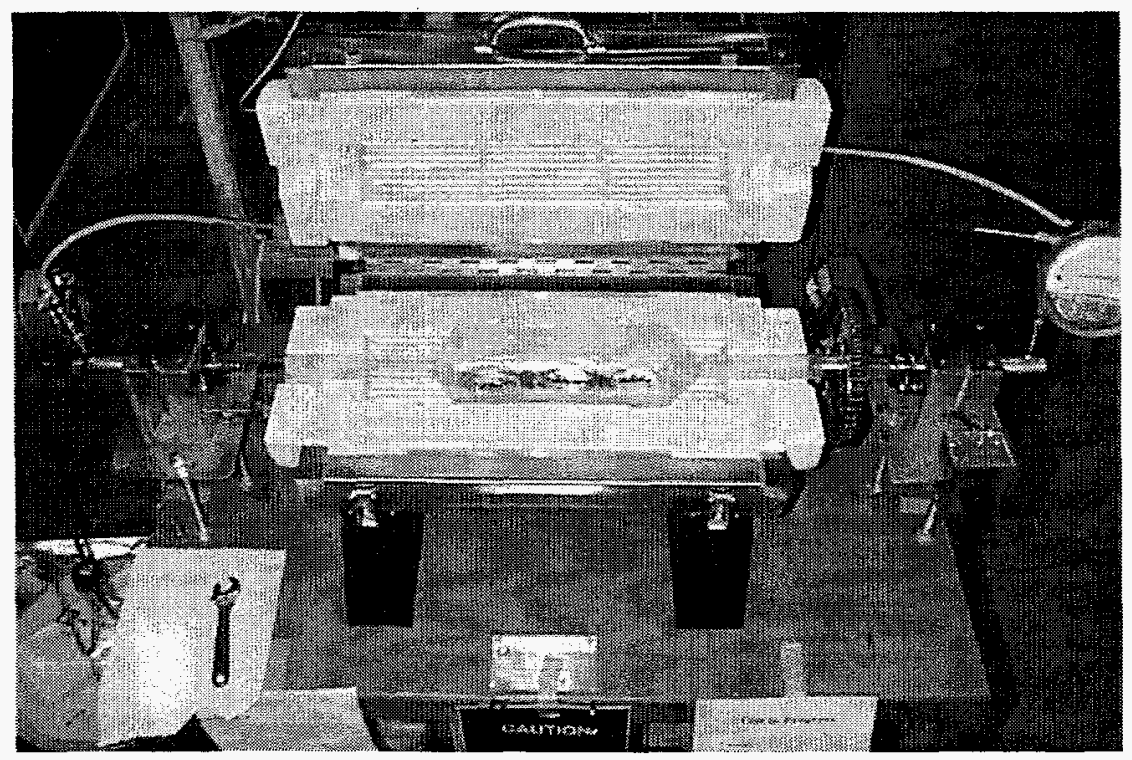

Figure 5.6. Bench-scale Rotary Calciner with Quartz Reactor

The reactor was swept with either argon or air as a cover gas, with helium injected at around $4 \%$ (by volume) to be used as a tracer gas. All gas streams were added via mass flow controllers from bottled sources. During one test, the calciner was also fitted with a $\mathrm{NO}_{\mathrm{x}}$ analyzer that yielded real time $\mathrm{NO}_{\mathrm{x}}$ concentration data via an analog gauge.

During some tests, a portable GC was available for evaluating the offgas from the reactor. Otherwise, there was a sample port on the exit line of the reactor where gas samples could be removed through a septum via a gas-tight syringe. These samples were then injected on a standalone $\mathrm{GC}$ with a thermal conductivity detector in a nearby laboratory to evaluate $\mathrm{N}_{2}, \mathrm{O}_{2}, \mathrm{CO}_{2}, \mathrm{H}_{2}$, and $\mathrm{CH}_{4}$.

\subsubsection{Experimental Testing}

The tests were performed using LAW evaporator bottoms simulant (Table 3.1) and mixing it with a diluent and a reductant before reacting it in the calciner. The diluents used in this testing were flyash and Micro-Cel E, both provided by INEEL. The reductants tested were sugar and glycolic acid. In some cases, the simulant, diluent, and reductant mixture were dried in a vacuum oven to remove water before testing.

For each of the tests, the simulant (wet slurry) was mixed with the diluent, and the reductant then added. When glycolic acid reductant was tested, it was added directly to the premixed simulant. When sugar reductant was tested, a finely divided, food-grade powdered sugar was added to the simulant and diluent and mixed carefully. The resultant product was a solid, as the diluent tended to absorb most of the free liquid from the simulant. The mixture was then added directly to the calciner. The reactor was rotated and a purge of either air or argon was used to cover the reactor, to which a $4 \%$ helium stream was 


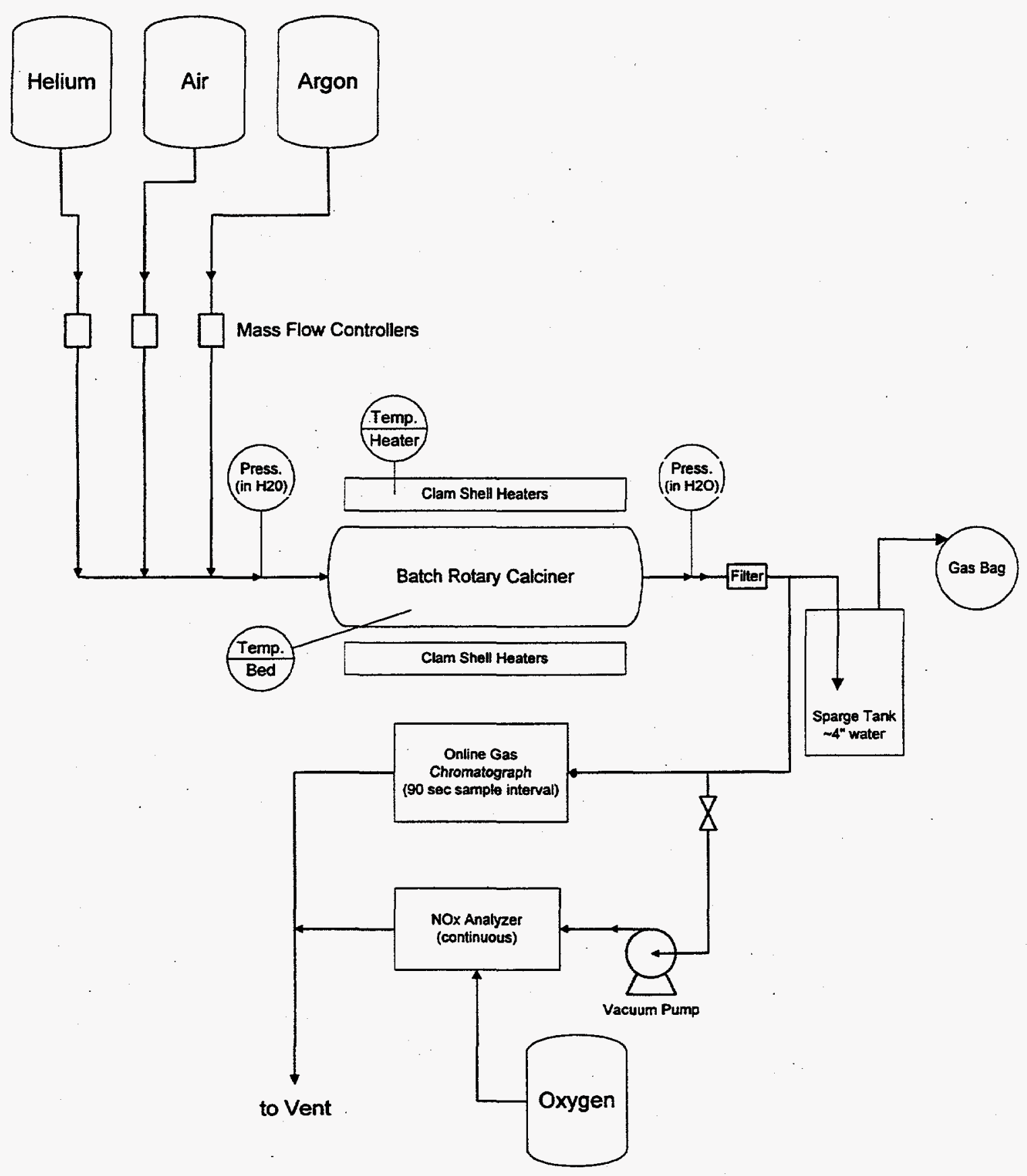

Figure 5.7. Component Diagram for Rotary Calciner

added. The helium was used to track the evolution of gaseous products in the reactor. The reactor contents were slowly heated to a predetermined setpoint, and temperature and pressure were monitored during heatup. 
During the test, measurements were taken from the two pressure gauges, one bed thermocouple and one heater thermocouple. When available, a single channel datalogger was used to record bed temperatures every 20 seconds; otherwise measurements were taken manually. In addition, the portable GC, when available, was used to pull samples from the exit gas line every 90 seconds. Otherwise, samples were taken via a gas syringe port and injected into the GC in a nearby laboratory. In some cases, the clamshell heaters were propped open about $1 \mathrm{in}$., and a small video camera was used to visually monitor the reaction through a nearby monitor. For one run, a $\mathrm{NO}_{\mathrm{x}}$ analyzer was available that continuously monitored the concentration of $\mathrm{NO}_{\mathbf{x}}$. Although the analyzer was calibrated at the widest range possible, during the ignition point of the calcined material, the $\mathrm{NO}_{\mathrm{x}}$ concentration exceeded the maximum quantification range of the analyzer.

The heating rate of the calciner ranged between 5 and 20 degrees per minute (as measured by the bed temperature thermocouple). A typical heat profile for the reactor is shown in Figure 5.8. As a general rule, the heatup was performed quickly, and it was slowed down or stopped during observed events such as water removal, smoking, pressure excursions, and ignition. Temperatures were recorded for such events, and then the heatup continued to a predetermined temperature, at which point the reactor was held at temperature and then cooled. Following a test, the resulting material was weighed and collected and then analyzed for TOC on a Xertex-Dohrmann Model D-80 carbon analyzer and for nitrates via Dionex Series $4000 \mathrm{i}$ ion chromatograph.

\subsubsection{Results and Discussion}

Table 5.7 contains the feed conditions and Table 5.8 provides the summarized results from the rotary calciner testing, showing run conditions, reacted components, onset temperature, and key analytical results. Complete run summaries, along with temperature profiles and other results, are provided in Appendix C.

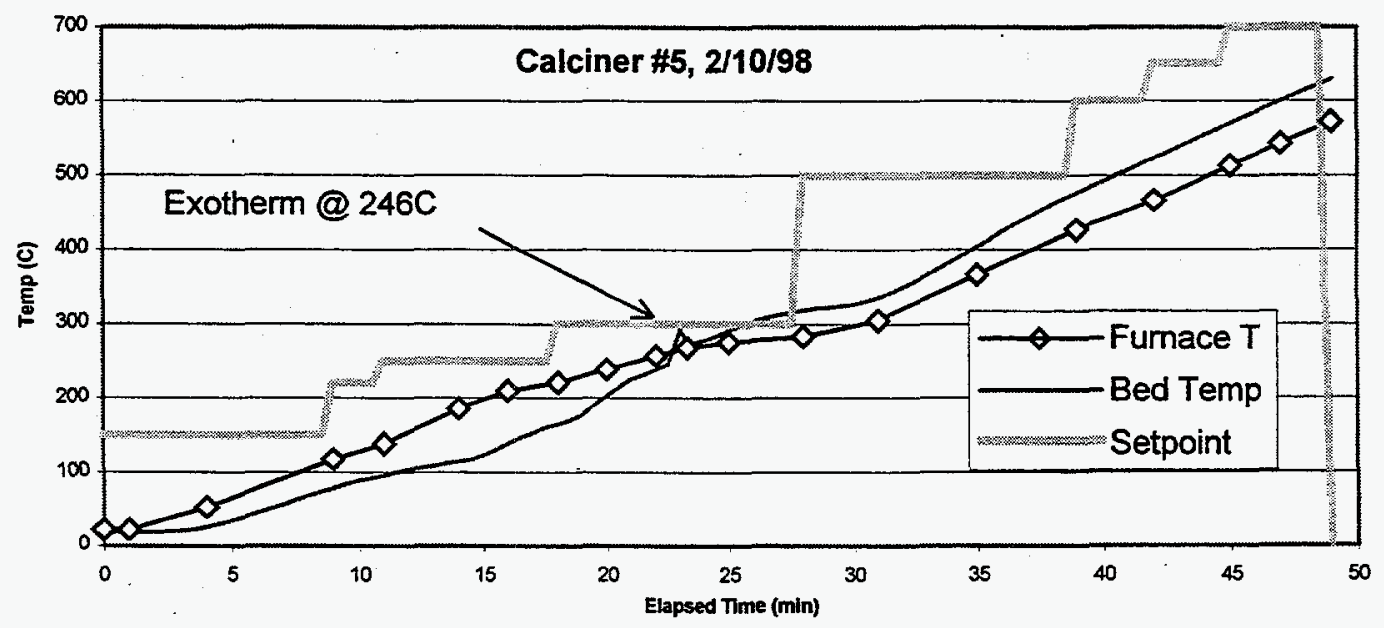

Figure 5.8. Temperature Profile for Run 5 


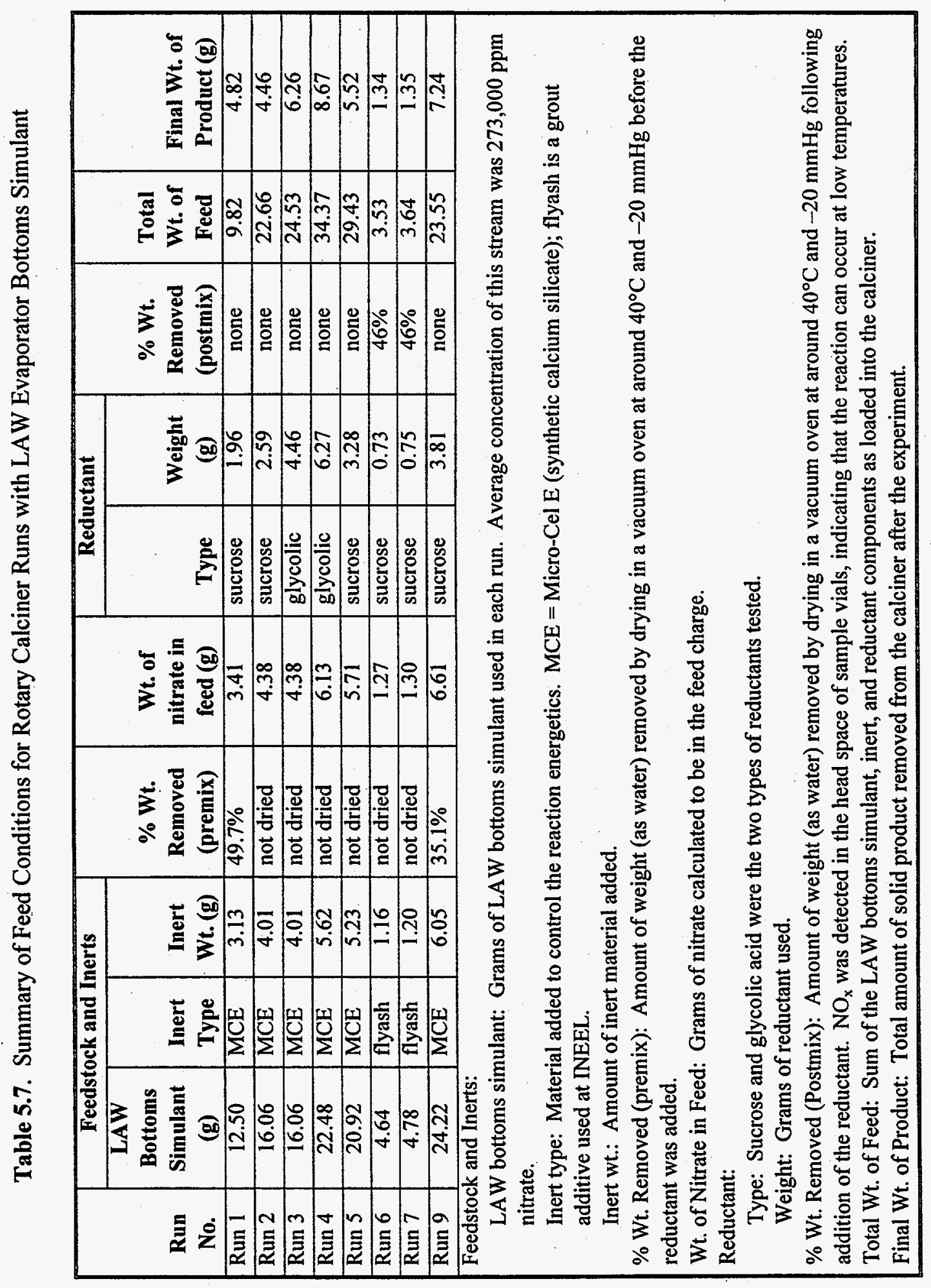




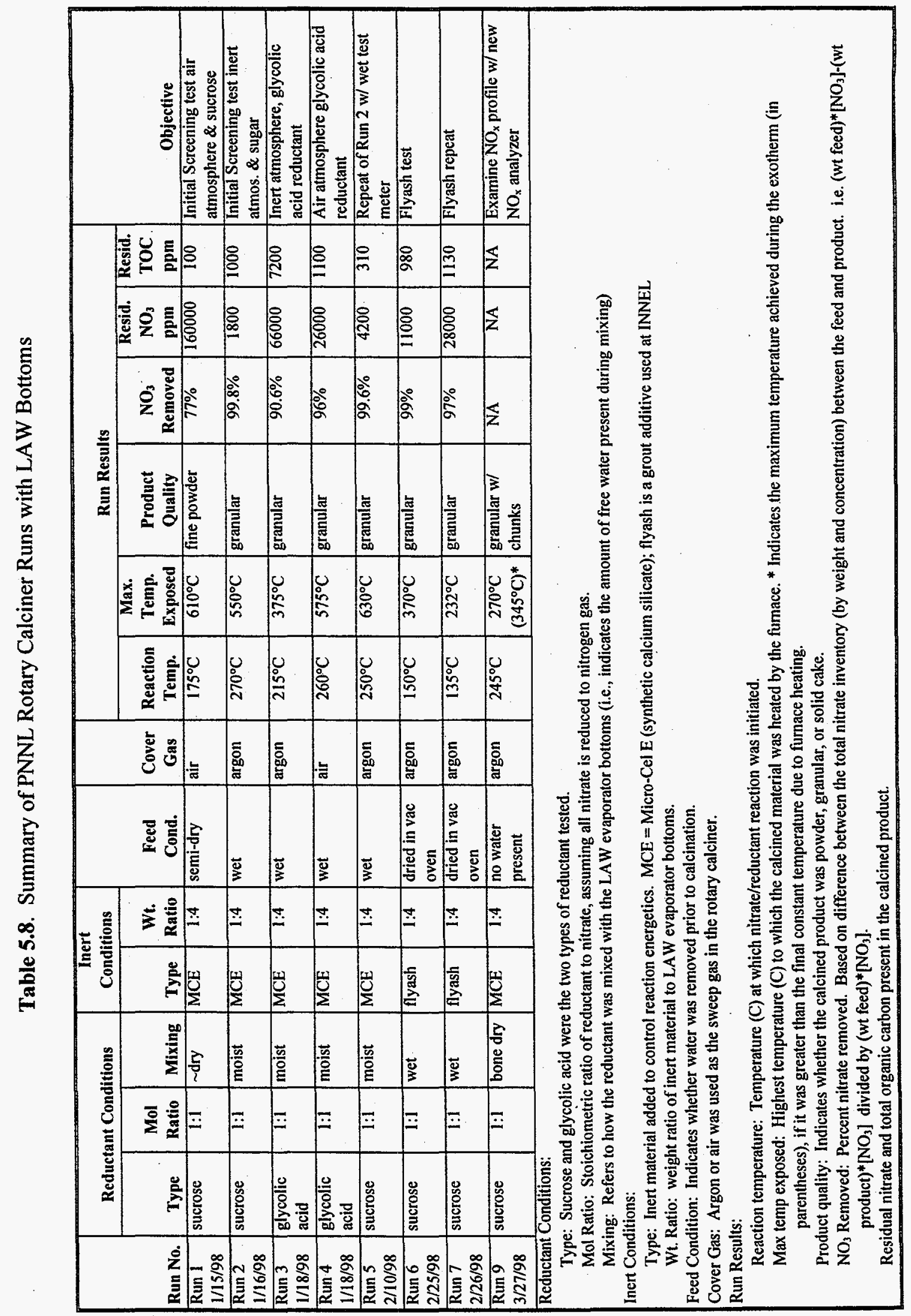




\subsubsection{Denitration Reaction}

Through this set of experiments, it was determined that denitration of this particular feedstock can be performed using bulk rotary calcination, and in some cases, at better conditions than might have been predicted in the scoping and pot calciner tests. Note that the denitration results presented are based on nitrate removal from the LAW bottoms simulant, which has already been distilled to remove up to $50 \%$ of the nitrates in the original LAW simulant. The result is that global nitrate removal is higher than the reported values when considering the entire process.

A significant observation from this set of experiments is that thorough contact between the nitratebearing waste and the reductant must be achieved to yield high nitrate reduction. This was illustrated in comparing Run 1 with Runs 2-5. In Run 1, the feedstock was prepared by loading the LAW bottoms simulant at a ratio of 1:4 (inert:LAW bottoms) onto the Micro-Cel E diluent. This slightly moist mixture was then partially dried until about $50 \%$ of the mass (as water) was removed. After drying, the reductant (in dry form) was mixed with the simulant and then loaded into the reactor. In subsequent tests, the dry reductant was added directly to the moist simulant/Micro-Cel E mixture, which allowed some of the sugar to dissolve into the moist waste form. The mixture was then added to calciner, and further commingling may have occurred during the heatup cycle while water was still present in the waste form. This seemed to provide more complete denitration than the first test where the reductant was added dry.

The resultant product from the first test showed considerable nitrate still present in the ash when compared to the other tests in the matrix, as shown in Table 5.8. It is therefore suggested that the bulk mixing of the reductant and nitrate-bearing stream occurs in a liquid or a slurry phase where intimate contact between the species can take place before calcination.

In the matrix of tests conducted, the sucrose reductant apparently yielded slightly higher nitrate reduction than the glycolic acid at equivalent stoichiometry, as indicated by comparison of Run 2 (sucrose reductant under argon) and Run 3 (glycolic acid reductant under argon). Initially, this slight disparity between the final nitrate reduction levels, $99.8 \%$ versus $90.6 \%$, was explained by the fact that the glycolic acid test was only taken up to 160 degrees past the exotherm reaction point $\left(215^{\circ} \mathrm{C}\right)$ to $370^{\circ} \mathrm{C}$, while the sucrose test was taken 280 degrees past its exotherm $\left(270^{\circ} \mathrm{C}\right)$ to $550^{\circ} \mathrm{C}$. However, later testing, in Runs 5 and 6 , indicated that $97 \%$ to $99 \%$ nitrate reduction can occur with sucrose without exceeding $370^{\circ} \mathrm{C}$. Thus, there appears to be a slight performance improvement using sucrose over glycolic acid for this testing with respect to achieving denitration.

Also, in comparing the tests where air was used as the cover gas (Runs 1 and 4) with the tests where argon was used (Runs 2 and 3), it appears that there was no significant effect on the final nitrate removal by having an oxidizing atmosphere in the calciner. However, an air atmosphere may have a tendency to consume some of the reductant under some conditions.

Finally, residual TOC in the ash seems to be related to the maximum temperature achieved in each test. The lowest TOC readings (Runs 1 and 5) occurred in tests that ended above $600^{\circ} \mathrm{C}$, while the highest TOC readings occurred in the other tests, where maximum temperatures were between $370^{\circ} \mathrm{C}$ and $550^{\circ} \mathrm{C}$. This difference is most likely due to volatilization of excess reductant at higher temperatures. 


\subsubsection{Reaction Observations}

Observing the exothermic reaction provided valuable information and insights into the application and scaleup of the process. In Table 5.8, an onset temperature was recorded for each of the tests. This temperature was estimated by analyzing the bed thermocouple, the calciner pressure record, visual observations, and helium tracer gas data where available. A sample plot of temperature/gas flow analysis is shown in Figure 5.9.

The plot was created by overlaying the temperature data with a calculated gas flow measurement. These data are developed by mixing a known flow rate of helium with a known flow rate of the sweep gas, and then tracking the helium with the online GC. The effective dilution of the helium gas is measured to determine the amount of gas generated in the calciner at that point. It should also be noted that, on this plot, the reaction onset is followed by an exotherm where the slope of the bed temperature changes in relation to the furnace temperature, and the bed temperature remains, from that point on, above the furnace temperature. This holds true for all of the other experiments conducted with this feedstock in the calciner.

The onset temperature appears somewhat repeatable, as in Runs 2 through 5 , where Micro-Cel $\mathrm{E}$ was used as the diluent; the onsets ranged from $215^{\circ} \mathrm{C}$ to $270^{\circ} \mathrm{C}$. Run 1 had a much lower onset $\left(175^{\circ} \mathrm{C}\right)$, but this may have been due to the lack of water held up in the feedstock and vaporizing as the temperature increased. Final denitration results did not seem to follow any obvious trend with respect to atmospheres (air or argon) or reductants (sugar or glycolic acid).

For the flyash tests, it was apparent that the onset temperatures were lower. Runs 6 and 7 had ignition temperatures of $150^{\circ} \mathrm{C}$ and $135^{\circ} \mathrm{C}$, respectively. Both of these tests used the same reaction conditions,

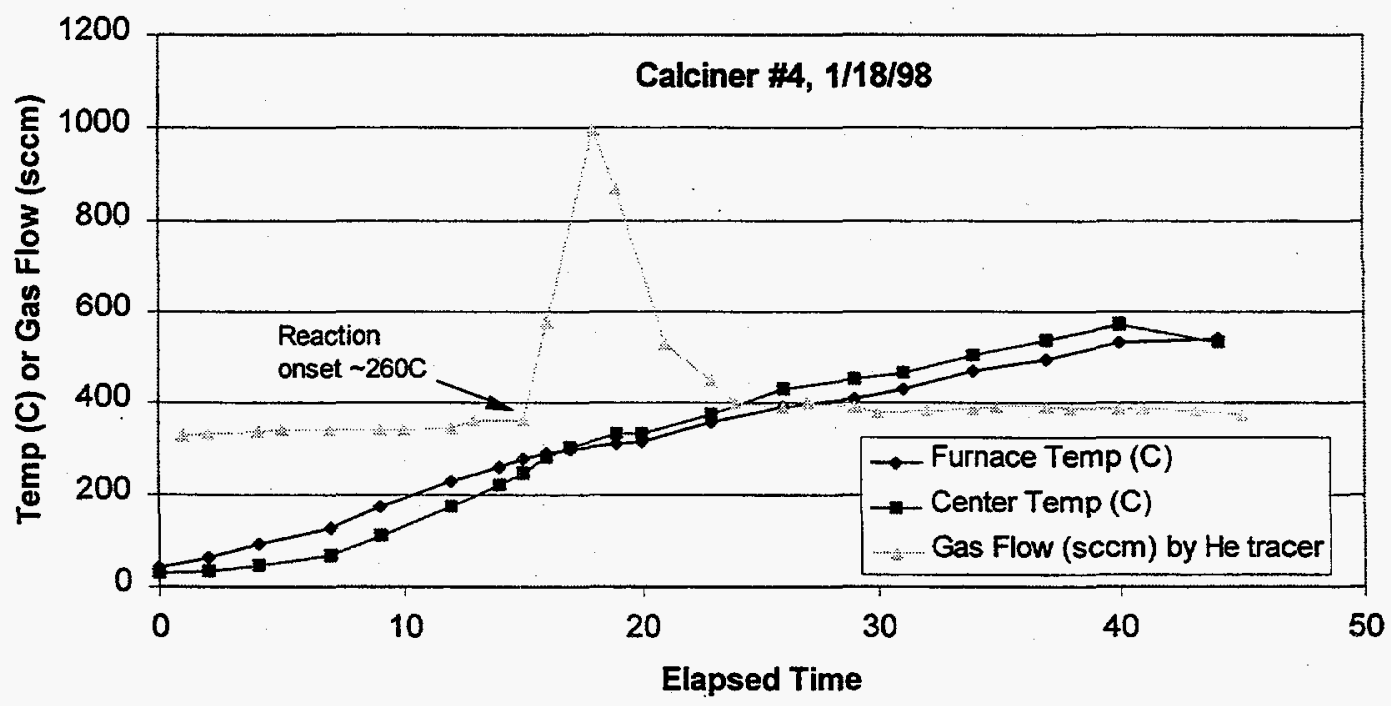

Figure 5.9. Temperature and Gas Flow Profile for Run 4 
feedstock, cover gas, and nearly the same heatup profile, with the exception of the ending temperature. It should also be noted that the feedstock was dried in a vacuum oven prior to calcining, similar to Run 1 with Micro-Cel E. Even so, the reaction onset temperature was still repeatedly below that of Run 1 .

Other observations worth noting concerned the visual data generated during the calcination tests. There was no observable flame generated during the exothermic reaction. Following ignition, white vapor would fill up both the calciner (observable by opening the clamshell heaters) and the glass arm used as a gas outlet. The white vapor was not specifically identified, but it very likely may have been water vapor. In some cases, the vapor had a light brown tinge, possibly indicative of $\mathrm{NO}_{\mathrm{x}}$. In addition, following most of the experiments, the residual ash in the calciner bed was a flowable powder. While some of the tests resulted in larger granules than others, the resultant ash never adhered to the walls in any other fashion besides static electrical attraction. In Run 7, a ball of melted slag formed that was larger than the granular product from other tests, but it did not show any signs of adhering to the reactor walls.

\subsubsection{Gas Products}

The gas products were analyzed in five different ways across the run matrix: pressure monitoring, product volume measurement using helium tracer, product volume measurement by wet test meter, gas analysis by discrete sampling (standalone GC), gas analysis by online GC ( 90 -second intervals), and gas analysis by $\mathrm{NO}_{\mathrm{x}}$ detector (continuous). Not all analysis methods were applied to all experiments, subject to equipment availability and compatibility.

A typical pressure plot for one of the experiments (Run 2) is shown in Figure 5.10. Note that the system is configured to relieve any pressures exceeding 4 in. water column (wc) to a knockout pot, and the actual pressures recorded at 4 in. wc are often higher.

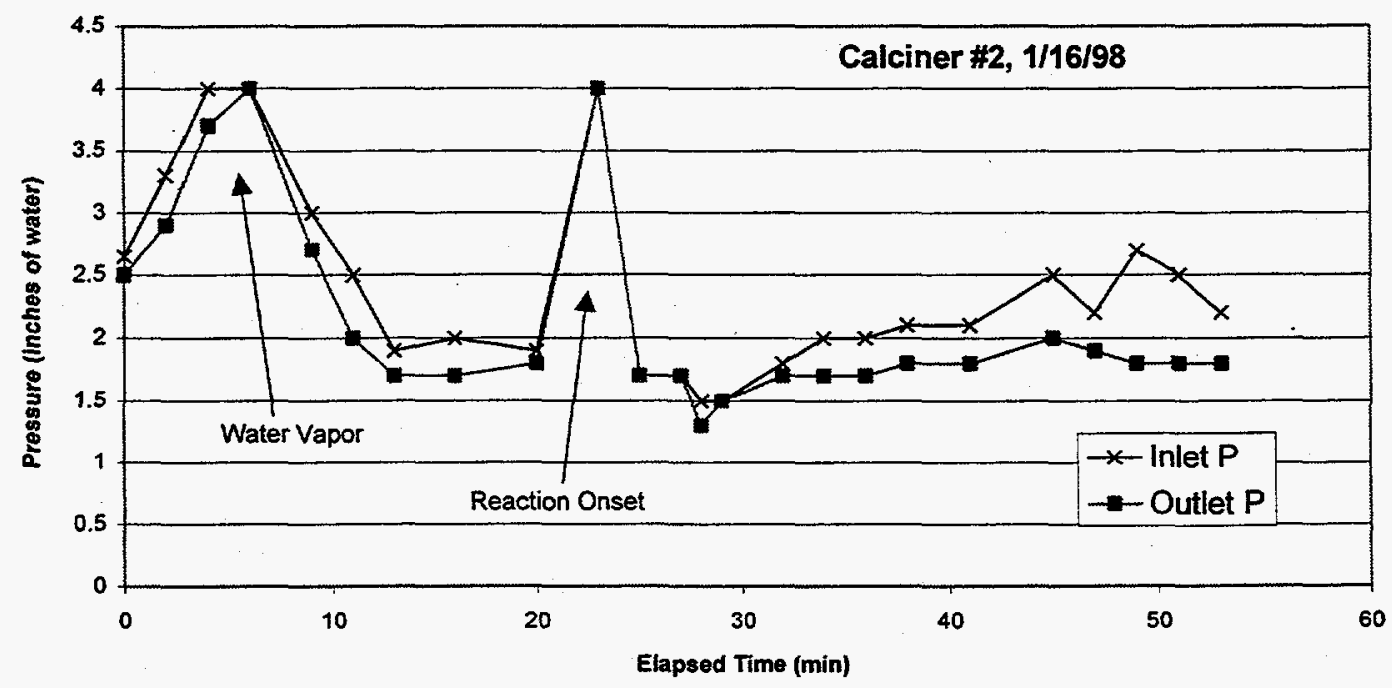

Figure 5.10. Pressure Profile for Run 2 
Note that the maximum displayed pressure of $4 \mathrm{in.} \mathrm{wc}$ is not the actual maximum pressure in the calciner. The knockout vessel was set to $4 \mathrm{in}$. wc through the use of a dip tube to ensure that the quartz reactor was not subjected to excessive pressures. The pressure gauges were also used as a leading indicator of an imminent reaction occurring in the calciner or when water was being vaporized from the feedstock. The pressure gauges would begin to move erratically before the actual ignition of the reactor contents and then go off scale (4 in. wc).

Species profiles from the GCs yielded insight into the reactions occurring in the calciner during an experiment. A typical species plot for an inert gas test is shown in Figure 5.11 (Run 2). Note that in this plot, the argon cover gas and the $\mathrm{NO}_{\mathrm{x}}$ formed during the reaction are not present. The $\mathrm{GC}$ was unable to detect either of these gases. The argon balance was not necessary, as the total flow for the system could be calculated using just the helium accounted for during the test. Note also the minor presence of oxygen in the detected gases. This is not due to an artifact of the calcination process but a mass flow controller malfunctioning and allowing a small amount of oxygen to enter with the argon sweep gas. The unidentified gas is still undetermined, but may be an artifact of the large amount of $\mathrm{NO}_{\mathrm{x}}$ in the gas product, or other species. A similar plot for Run 4, an air cover gas experiment, is shown in Figure 5.12. Note that the peak is not properly calibrated for $\mathrm{NO}_{\mathrm{x}}$, and is not indicative of the relative concentration of the $\mathrm{NO}_{\mathrm{x}}$ in the gas stream.

The extent of $\mathrm{NO}_{\mathrm{x}}$ formation was determined with an online, real-time $\mathrm{NO}_{\mathrm{x}}$ analyzer, acquired and set up for Run 9. This unit, used in conjunction with the standard online GC, was calibrated at its maximum range to obtain the highest peak of $\mathrm{NO}_{\mathrm{x}}$ formed during the test. Samples for the $\mathrm{NO}_{\mathrm{x}}$ analyzer were taken as a slipstream from the main product gas exhaust line. The plot of both the $\mathrm{GC}$ and $\mathrm{NO}_{\mathrm{x}}$ analyzer data is shown in Figure 5.13. Note that the concentrations of $\mathrm{NO}_{\mathrm{x}}$ in the gas product were over the calibration

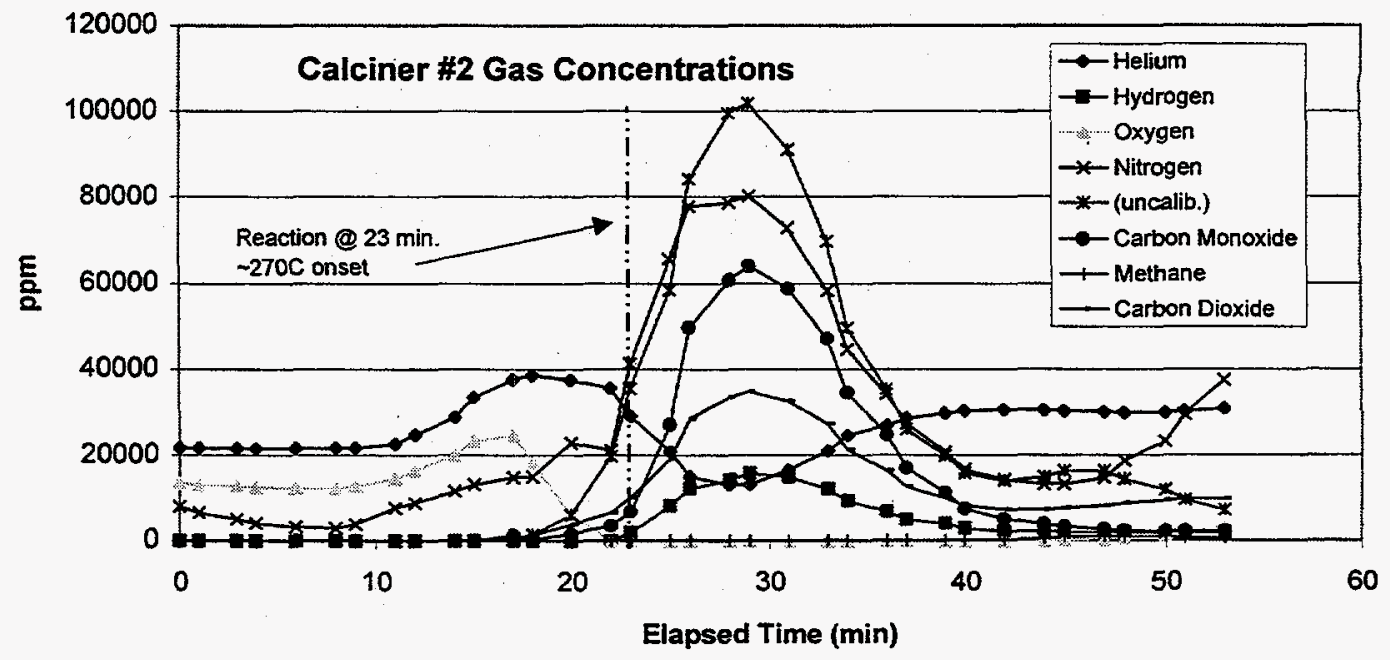

Figure 5.11. Gas Product Concentrations for Run 2 


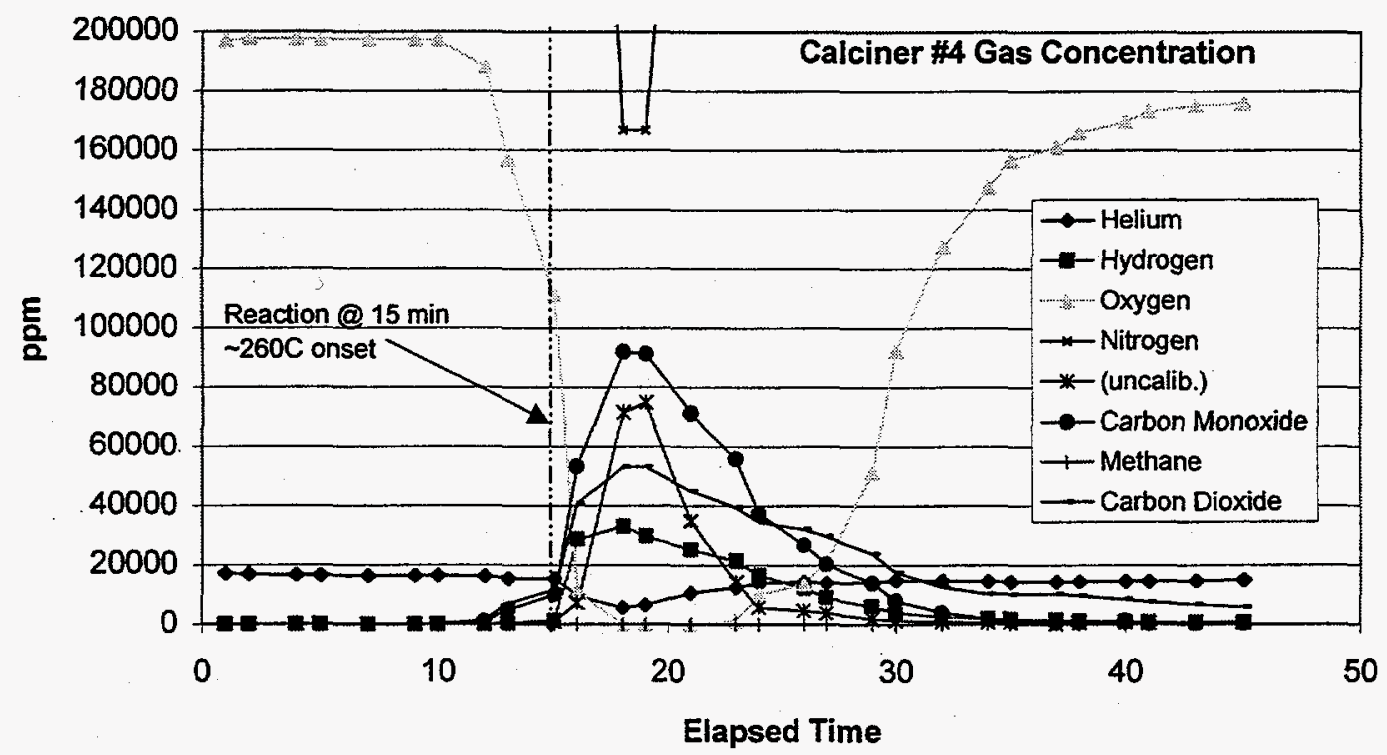

Figure 5.12. Gas Product Concentrations for Run 4

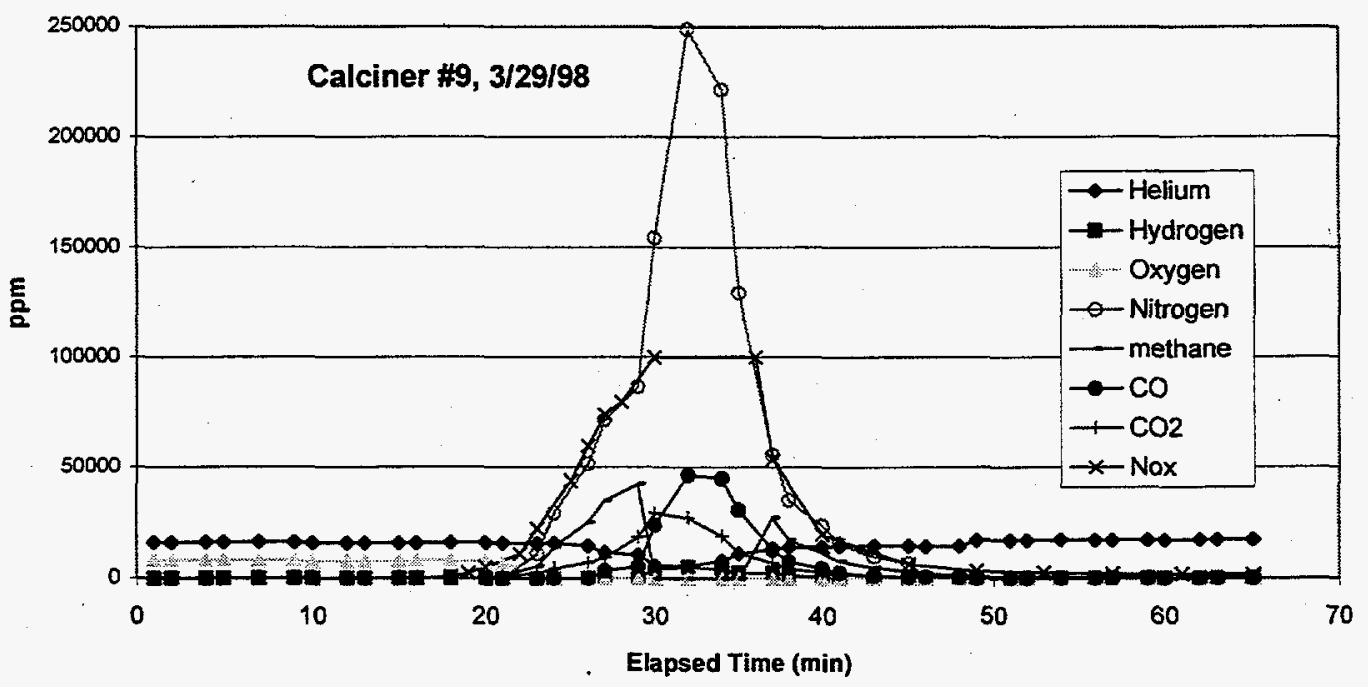

Figure 5.13. Gas Product Concentrations for Run 9

range of the analyzer at $10 \%$ by volume. The highest concentration of $\mathrm{NO}_{\mathrm{x}}$ was not determined. However, examining the combined plot of GC-detected gases and data generated from the $\mathrm{NO}_{\mathrm{x}}$ analyzer, it appears that the nitrogen peak from the $\mathrm{GC}$ and the $\mathrm{NO}_{\mathrm{x}}$ peak correspond very closely (in the ranges where the $\mathrm{NO}_{x}$ data are available).

Cumulative gas production for five selected experiments is shown in Table 5.9. Cumulative gas flows were calculated through the use of the GC data. First, a total instantaneous gas flow rate was 
Table 5.9. Gas Product Summary for Selected Tests

\begin{tabular}{|c|c|c|c|c|c|c|c|c|c|c|c|}
\hline \multirow[b]{2}{*}{$\begin{array}{l}\text { Run } \\
\text { No. }\end{array}$} & \multicolumn{11}{|c|}{ Cumulative Gas Production in Standard Cubic Centimeters } \\
\hline & $\begin{array}{c}\text { Nitrate } \\
\text { in feed } \\
\text { (g) }\end{array}$ & $\begin{array}{l}\text { Reduct. } \\
\text { reagent }\end{array}$ & $\begin{array}{c}\text { Cover } \\
\text { gas }\end{array}$ & $\mathbf{H}_{2}$ & $\mathbf{O}_{2}$ & $\mathbf{N}_{\mathbf{2}}$ & $\begin{array}{c}\mathrm{NO}_{3} \text { Conv. to } \\
\mathrm{N}_{2}, \mathrm{wt} \% \mathrm{~N}\end{array}$ & Uncalib. & $\mathbf{C O}$ & $\mathrm{CH}_{4}$ & $\mathrm{CO}_{2}$ \\
\hline Run 1 & $\overline{3.41}$ & sucrose & air & 0.48 & 5289 & 22412 & $\mathrm{NA}$ & 2.45 & 61.9 & 0 & 122 \\
\hline Run 2 & 4.38 & sucrose & argon & 60.5 & 69.2 & 405 & $51 \%$ & 396 & 225 & 2.13 & 154 \\
\hline Run 3 & 4.38 & glycolic & argon & 71.5 & 80.5 & 206 & $26 \%$ & 179 & 179 & 1.16 & 135 \\
\hline Run 4 & 6.13 & glycolic & air & 190 & 1980 & 10700 & $\overline{\mathrm{NA}}$ & 276 & 495 & 0 & 401 \\
\hline Run 9 & 6.607 & sucrose & argon & 26.2 & 62.6 & 1376 & $115 \%$ & 150 & 236 & 0 & 173 \\
\hline
\end{tabular}

calculated by the use of a helium tracer gas in the known flow rate of sweep gas. This was calculated by taking the known concentration of helium and using the analytical result for helium to determine its dilution. Next, the instantaneous gas flow rate was determined for that sampling interval. The cumulative gas flow rates of each component were determined by multiplying the percentage of that component analyzed in the GC data by the total flow rate and by the length of the sampling interval. Summing these results from every data interval yielded the total volume of each species exiting the calciner. Note that for Runs 1 and 4 the high oxygen and nitrogen totals are due to the use of air as the sweep gas. While the above results may not exactly quantify the full amounts of species generated due to gas outleakage from the blowdown tank and the inherent difficulties in using a tracer gas in an environment with a dynamically changing pressure and gas flow rate, they should be used to provide relative estimates of the amounts and types of gases expected to be produced from the calcination of this waste form. 


\subsection{Engineering Evaluation and Alternative Flowsheet Development}

The engineering evaluation incorporated previously developed process information and laboratory testing to determine the most appropriate options for full-scale application. The industrial equipment evaluated was selected based on a comprehensive survey of chemical processing industries throughout the world, including chemical, petrochemical, mineral, and waste processing. Applicable vendors were also contacted.

Various flowsheets were considered and are discussed here. A flowsheet design basis of $1000 \mathrm{~kg} / \mathrm{hr}$ is used in this discussion to simplify scaling and provide a uniform basis for comparing alternatives. Several sources of action are recommended that will ensure the denitration technology can safely and efficiently be implemented for INEEL and for other high nitrate waste streams.

\subsection{Process Requirements}

The work conducted for this report focused on the processing requirements for removing the bulk of the nitrate concentration in the INEEL LAW. In the current flowsheet, the denitrated product will be grouted directly. However, the processes described below may be applicable to a variety of nitratebearing waste streams.

\subsubsection{Residual Nitrate in Product}

Perhaps the most important overall process requirement is the final residual nitrate in the calcined product. INEEL specified the following criteria (Barnes et al. 1997):

The LLW flow scheme will not specify the type of denitration process or processes. It will be assumed that the denitration process will not use additives and will produce a dry solids product. Based on Table 2, FY-96 Status Report of the Low-Level Waste Grout Stabilization Development Program, A. K. Herbst, AKH-07-96, September 18, 1996, denitration will be assumed to be $70 \%$ complete for separations wastes from processing SBW, and $99 \%$ complete wastes from processing calcine. Offgas from denitration will be based on complete removal of water, the above denitration efficiencies, $100 \%$ removal of mercury, and no removal of radionuclides from denitration feed.

A Feasibility Study based on the above process information (Fluor-Daniel 1997) assumed a thermal denitrator typical in materials and design to the existing fluidized bed calciner which provided a $92 \%$ reduction of the nitrate. 


\subsubsection{Grout Loading}

A definitive residual nitrate loading requirement for the final Class $A$ Grout product has yet to be determined. Because of the nearly complete destruction of nitrate using sugar or glycine denitration, it may be possible to increase the overall grout waste loading, which could dramatically reduce the total volume and cost of grout.

Proposed grout loadings for various waste oxides identified in the Fluor-Daniel Feasibility Study are is listed below:

\begin{tabular}{|c|c|c|c|c|}
\hline $\begin{array}{c}\text { Kg/Kg Waste } \\
\text { Oxide }\end{array}$ & $\begin{array}{c}\text { Portland Cement } \\
\text { Type I/II }\end{array}$ & $\begin{array}{c}\text { Class F } \\
\text { Flyash }\end{array}$ & $\begin{array}{c}\text { Blast Furnace } \\
\text { Slag }\end{array}$ & Water \\
\hline SBW & 0.78 & 0.78 & 0.78 & 1.16 \\
\hline Al Calcine & 1.89 & 1.89 & 1.89 & 2.77 \\
\hline Zr Calcine & 0.78 & 0.78 & 0.78 & 1.48 \\
\hline Mixed Calcine & 0.94 & 0.94 & 0.94 & 1.68 \\
\hline
\end{tabular}

Actual waste loading for the SBW solids is then $1 \mathrm{~kg}$ per $(1+0.78+0.78+0.78+1.16 \mathrm{~kg})$ or approximately $22 \%$ by weight, neglecting the small amount of plastic additives.

\subsubsection{Waste Preparation/Handling}

The LAW streams produced during the SBW separation processes contain a substantial amount of water and nitrate as nitric acid, which can be removed prior to denitration. Perhaps as much as $50 \%$ of the nitrate can be removed as nitric acid for recycle to the process. This will reduce the process requirements for the denitration reactor by half and make any diluents added for reaction control more effective with regard to heat of reaction. All flowsheets include some type of evaporator. Either a wiped or falling film vacuum evaporator should perform well in this application. Certain additives are specified below (Barnes et al. 1997):

Additives, such as nitric acid, caustic, and ANN may be needed in the LLW evaporator (including the PEW during the years it's operating), in the feed and/or in the evaporator to control corrosion and to control organics in evaporator overhead. For the PEW evaporator, ANN is added to the feed maintain a Al:F molar ratio above 2 and nitric acid is added to maintain a $\mathrm{pH}$ greater than 4 . Calcium nitrate addition is shown on the total calcine and $\mathrm{Zr}$ calcine flowsheets and material balances to control fluorides in the feed. The calcium nitrate rate in the material balance is based on the amount that will bring the total calcium in the feed to 0.5 mole fraction of the fluoride in the feed.

In a previous INEEL document (Fluor-Daniel 1994), sugar denitration in an existing fluid bed was the baseline flowsheet. A screw dryer was discussed as an alternative way to produce a dry product before the waste stream is sent to a rotary kiln reactor. The screw dryer was designed to be used following a vacuum evaporator and was expected to further concentrate the feed to dryness. Based on the extreme 
reactivity of organic/nitrate mixtures at relatively low temperatures (see Reaction Calorimetry Section) and the potential for substantial inventory of reactive material, we do not recommend the use of a screw dryer with an organic reductant.

One option future testing would be to mix the concentrated evaporator bottoms with the organic reductant, fly ash, and cement in proportions substantial enough to allow briquetting. These small briquettes could then be processed through a rotary kiln. Enough diluent must be used to absorb a portion of the heat released and control the reaction. Substantial research and development went into similar concepts pertaining to the use of an electric arc furnace at the U.S. Bureau of Mines (Eaton 1995). This work was directed at denitrating Hanford waste feeds to be vitrified rather than grouted. However, stable pellets containing $25 \%$ waste loading and a variety of inerts were prepared using two different preparation methods (A and B). In particular (Eaton 1995) noted:

Loaded A pellets were partially dried by radiant heating on a belt conveyor and subjected to thermal treatment in the steel belt dryer... Drying was completed on the steel belt, and then reaction between reductants and nitrogenous species occurred. The maximum air temperature measured within the steel belt dryer while processing loaded $A$ pellets was about $350^{\circ} \mathrm{C}\left(662^{\circ} \mathrm{F}\right) \ldots$ at no time did the detectors indicate the presence of $\mathrm{NO}_{\mathrm{x}}$ (using pelletization method $\mathrm{A}$ ). Method $\mathrm{B}$ resulted in $65 \%$ conversion to $\mathrm{N}_{2}$ in one test.

It should be noted that boric acid was added to the above pellet mixture at about 5 dry wt $\%$, presumably to slow down the reactions.

Solutions containing any reductant should not be mixed or handled at elevated temperatures or stored for any length of time. Mixing should be accomplished with inline static mixers. Inventory of mixed feed should not be allowed to accumulate.

\subsubsection{Reductant Chemistry and Addition}

Several reductants are being evaluated for use in the denitration process. The two primary alternatives being considered are sugar and glycine. More definitive chemistry of the reactions is outlined in Section 3.0.

\subsubsection{Offgas Handling}

Large volumes of gases are generated by converting the nitrate to elemental nitrogen gas during the denitration reactions. These gases, along with the sweep gases contain the residual small particulate oxides of the waste components and other products of partial oxidation. This gas stream must be scrubbed and then filtered (high efficiency particulate air, HEPA) to assure absolute particulate recovery. Best Available Control Technology (BACT) for this application may include several cyclone separators, a wet scrubber with fiber-packed mist eliminator, or a wet electrostatic precipitator, followed by two stages of HEPA filtration. 


\subsection{Proposed Flowsheets}

The baseline flowsheet employs the current INEEL fluidized bed calcination technology operating at elevated temperatures to increase thermal denitration. The other alternatives include sugar addition/fluid bed, high-temperature drying/rotary kiln, direct injection rotary kiln, glycine nitrate. Six main criteria were used for the evaluation:

- suitability for meeting system operating requirements

- technical availability

- operability

- ease of integration into existing INEEL facilities

- safety and environmental compliance

- design issues.

The flowsheets evaluated in terms of these criteria are presented individually in Sections 6.2.1 through 6.2.6. These sections are designed to give a separate overview of each flowsheet and accompanying technologies. 


\subsubsection{INEEL Base Case}

The baseline INEEL flowsheet (Figure 6.1) employs a high-temperature fluid bed calciner very similar to that currently employed at the Neutralized Waste Calcination Facility (NWCF). Since the existing calciner at INEEL cannot meet the required throughput to process the projected LLW inventory, this analysis assumes a new, appropriately sized, calciner vessel will be used.

Operating Suitability. The baseline flowsheet employs proven technology that has been in operation at INEEL for many decades. It is the most highly suited for operations with INEEL feedstocks and in these operating conditions. However, high-temperature calcination results in increased $\mathrm{NO}_{x}$ production and higher capital costs.

Technical Availability. Because the baseline flowsheet employs proven technology, it has the highest probability of success from a technical standpoint. There is a high level of technical maturity. Some issues of regulatory compliance have been raised with the current operation.

Operability. The ease of operability of fluidized beds is well known. However, agglomeration issues inherent in all fluidized bed applications mean that, over time, it is likely some bed volumes would have to be dumped directly to grout without being fully denitrated.
Ease of Integration. With the baseline flowsheet, there would be minimal disruption of current operations and the ease of integration of this technology into the current operation would be the highest.

Safety and Environmental. The baseline technology has operated safely for several decades, and would be expected to continue. However, several issues regarding environmental compliance have recently been raised by state and federal regulators. Compliance with the provisions of the Clean Air Act will require substantial expenditures for selective catalytic reduction $(\mathrm{SCR}) \mathrm{NO}_{\mathrm{x}}$ removal.

Design Issues. There are no unresolved design issues with respect to equipment availability and suitability. There is the highest level of confidence that current designs would accomplish the tasks desired.

INEEL Baseline Flowsheet Summary

Operating Suitability High

Technical Availability

High

Operability Medium

Ease of Integration

High

Safety and Environmental Medium Design Issues 


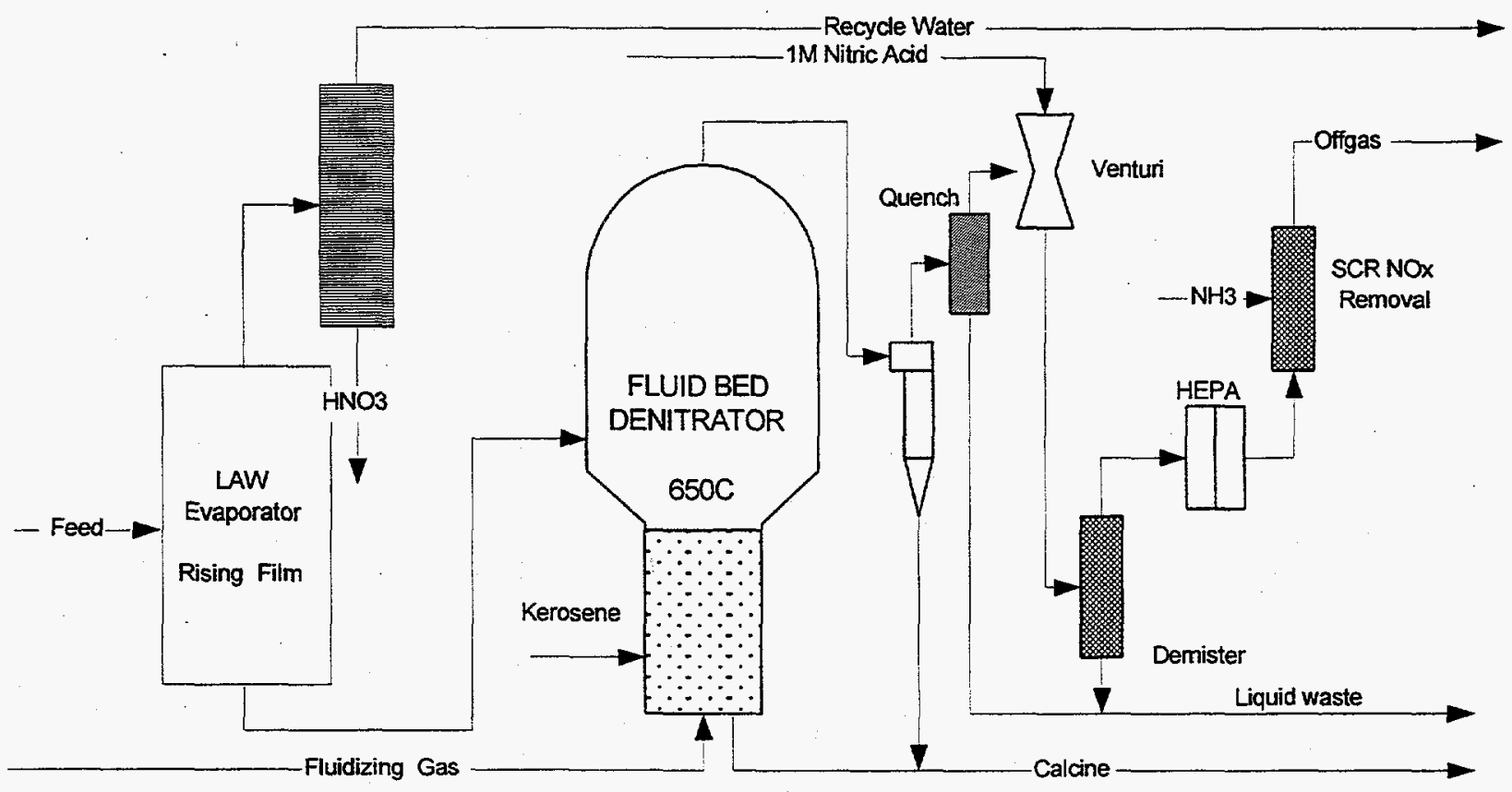

Figure 6.1. Baseline Flowsheet

The process basis document (Barnes et al. 1997) outlines the following generic criteria for grouting (including LLW evaporation and denitration):

- It is assumed that the LLW evaporator concentrates waste to a total solids content of about $520 \mathrm{~g} / \mathrm{L}$.

- Denitration will be assumed to be $70 \%$ complete for LAW and $99 \%$ complete for calcine. Offgas from denitration will be based on complete removal of water, the above denitration efficiencies, $100 \%$ removal of mercury, and no removal of radionuclides.

The Feasibility Study report prepared by Fluor-Daniel (1997) specified criteria for vacuum distillation and denitration:

- Water removal from this waste stream is maximized while sufficient water and acid are retained to prevent formation of precipitates.

- Overheads from evaporation are processed through distillation for acid recovery and recycle. Water recovered from this distillation is reused in plant operations.

- Design capacity is based on flow rates of LAW established for the processing of dissolved calcine.

- Denitrator equipment is sized for $55 \%$ operating efficiency. 
- Waste liquor is blended with recycle quench and additives (which vary depending on the campaign) and is atomized as feed to the fluidized bed operating at $650^{\circ} \mathrm{C}\left(1200^{\circ} \mathrm{F}\right)$.

- Offgas is first treated by cyclone. Fines and product are air conveyed to solids storage.

- Offgas is further treated through an acid quench, venturi scrubber and separator, demister, and filter prior to entering the SCR reactor, and finally discharged through the facility stack.

- PNNL experiments show that $50 \%$ nitrate removal by evaporation is reasonable.

\begin{tabular}{|l|r|r|c|}
\hline & \multicolumn{1}{|c|}{ Raw Feed $^{\text {(a) }}$} & Evap. Bottoms & Calcined Product \\
\hline $\mathrm{NO}_{3}$ & $145.6 \quad 50 \%$ removal & $72.8 \quad 70 \%$ destruction & 21.8 \\
\hline $\mathrm{Al}$ & 7.7 & 7.7 & 7.7 \\
\hline $\mathrm{Na}$ & 21.5 & 21.5 & 21.5 \\
\hline $\mathrm{H}_{2} \mathrm{O}$ & $825.2 \quad 83 \%$ vol reduction & $140.3 . \quad 100 \%$ removal & 0.0 \\
\hline TOTAL & $\mathbf{1 0 0 0 . 0}$ & $\mathbf{2 4 2 . 3}$ & $\mathbf{5 1 . 0 4}$ \\
\hline Volume, $\mathrm{kL}$ & $851.0 \quad 83 \%$ vol reduction & 144.7 & \\
\hline Density & 1.18 & 1.6 & \\
\hline (a) Basis $1000 \mathrm{~kg} / \mathrm{hr}$ raw feed. &
\end{tabular}




\subsubsection{INEEL Baseline+Sugar Flowsheet}

The baseline INEEL flowsheet with sugar addition (Figure 6.2) also employs a fluidized bed calciner very similar to that currently employed at the NWCF. Sugar is added to the calciner feed just before injection to allow operation at lower temperatures.

Operating Suitability. The baseline flowsheet employs technology very similar to technology that has been in operation at INEEL for many decades. It is the most highly suited for operations with INEEL feedstocks and in these operating conditions.

Technical Availability. Because the baselinet sugar flowsheet employs proven technology, it has the highest probability of success from a technical standpoint. There is a high level of technical maturity in the operation of the fluidized bed. Some issues of regulatory compliance have been raised with the current operation, which can be ameliorated by the denitration reactions of sugar with nitrates in the feed.

Operability. As in the baseline alone flowsheet, the ease of the fluidized bed operability is well known, although agglomeration issues are inherent in all fluidized bed applications. Previous pilot-scale experiments have not shown substantially higher agglomeration with sugar addition (Boardman 1997); however, they are based on small-diameter fluidized beds and a limited operating history. Over time, it is likely that some bed volumes would have to be dumped directly to grout without being fully denitrated.

Ease of Integration. Since the baseline flowsheet is currently employed at the INEEL for waste treatment, there would be minimal disruption of operations; the ease of integration of this technology into the current operation would be the highest.

Safety and Environmental. The baseline technology has operated safely for several decades and would be expected to continue. However, some concern has been expressed about the combination of organics such as sugar and oxidizer nitrate salts. The two key issues revolve around containment of the highly exothermic reaction in the fluidized bed, and the potential production of explosive char that could accumulate in downstream piping. Pilot-scale testing (Boardman 1997) shows the reduction reaction is controllable in a fluidized bed. Testing of aqueous sugar-nitrate reactions and resulting calcine reactivity showed relatively little propensity to form explosive nitrosugars and no potential to sustain a self-propagating reaction (Marshall and Green 1996).

Design Issues. There are no unresolved design issues with respect to equipment availability and suitability. There is the highest level of confidence that current designs would accomplish the tasks desired.

INEEL Baseline+Sugar Flowsheet Summary

Operating Suitability

High

Technical Availability

High

Operability Medium

Ease of Integration High

Safety and Environmental Medium

Design Issues High 


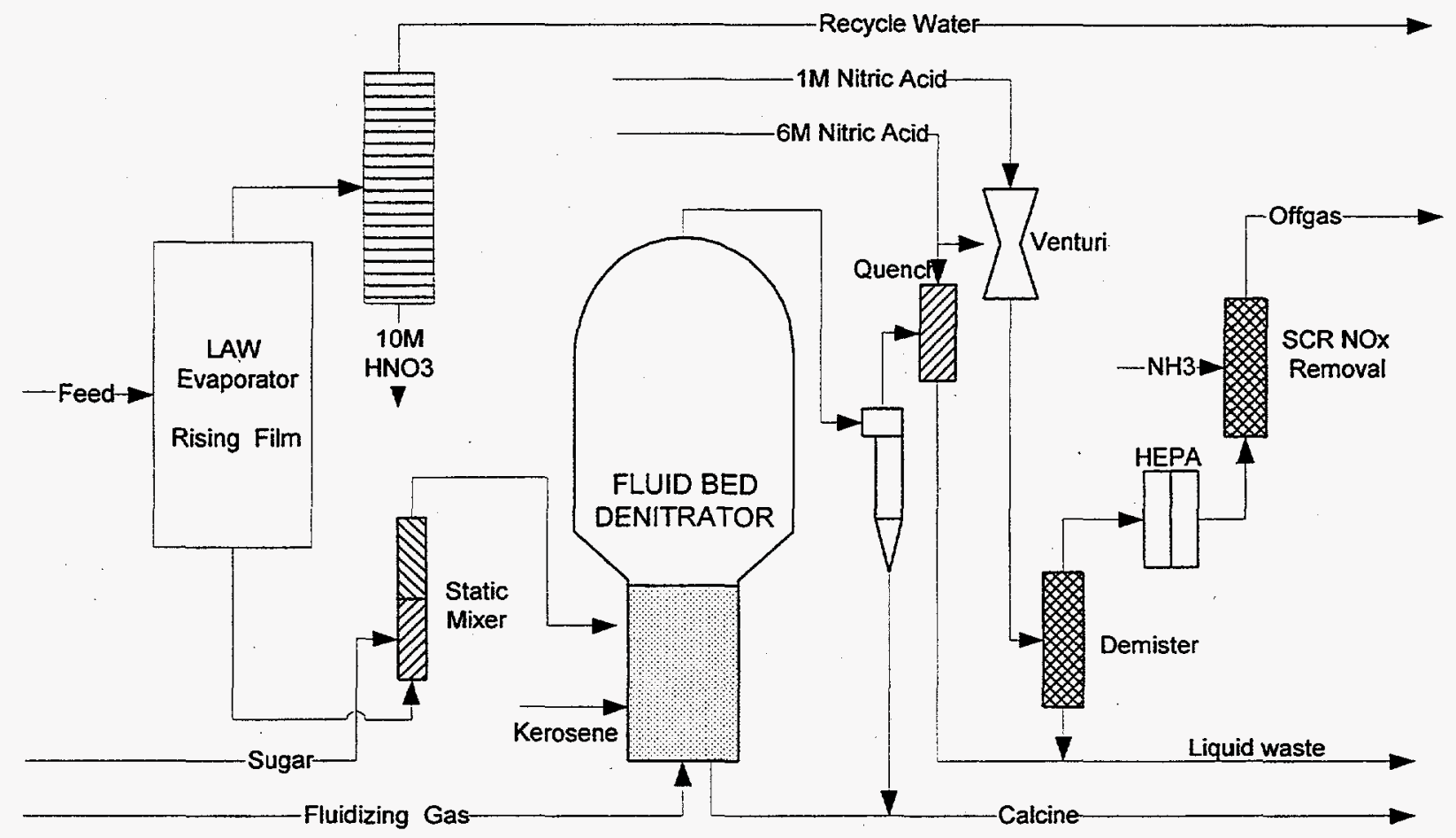

Figure 6.2. Sugar Addition Flowsheet

\begin{tabular}{|c|c|c|c|}
\hline & Raw Feed ${ }^{(a)}$ & Evap. Bottoms & Calcined Product \\
\hline $\mathrm{NO}_{3}$ & $145.650 \%$ removal & $72.8 \quad 95 \%$ destruction & 3.6 \\
\hline $\mathrm{Al}$ & 7.7 & 7.7 & 7.7 \\
\hline $\mathrm{Na}$ & 21.5 & 21.5 & 21.5 \\
\hline $\mathrm{H}_{2} \mathrm{O}$ & $825.2 \quad 83 \%$ vol reduction & $140.3 \quad 100 \%$ removal & 0.0 \\
\hline TOTAL & 1000.0 & 242.3 & 32.8 \\
\hline Volume, $\mathrm{kL}$ & $851.0 \quad 83 \%$ vol reduction & 144.7 & \\
\hline Density & 1.18 & 1.6 & \\
\hline
\end{tabular}

The process basis for the baseline+sugar flowsheet is identical to that of the baseline flowsheet, except for the direct addition of sugar to the feed prior to denitration. It is assumed that the sugar causes additional reductive denitration in the fluidized bed and converts $70 \%$ of the nitrate to nitrogen and $25 \%$ to $\mathrm{NO}_{\mathrm{x}}$. There is $5 \%$ residual in the bed solids and fines upon exit. 


\subsubsection{INEEL High-Temperature Drying/Rotary Kiln}

The INEEL high-temperature flowsheet

(Figure 6.3) employs an evaporator, screw dryer, and rotary kiln to sequentially remove nitrate in several stages prior to calcination. No reductant is used in this flowsheet.

Operating Suitability. The INEEL hightemperature flowsheet appears to meet system requirements for denitration of feedstocks. However, no pilot testing of this schematic has been conducted.

Technical Availability. The INEEL hightemperature flowsheet employs proven technology and thus has a high probability of success from a technical standpoint. However, no pilot testing of proposed equipment has been accomplished using representative simulants.

Operability. System operability of this flowsheet is potentially much easier than operating a fluidized bed. Removing most of the nitrate prior to calcination could substantially reduce the $\mathrm{NO}_{\mathrm{x}}$ that must be removed by SCR. If SCR will be used to control $\mathrm{NO}_{\mathrm{x}}$, then high burnouts of nitrates can be achieved in rotary kilns.

Rotary kilns have been shown to operate reliably for years with minimal maintenance. Some concern has been raised with respect to caking and agglomeration of calcine on the walls of a rotary kiln. Common practices such as chains or breakers have successfully reduced caking. This could be the kind of "hands-off" operation desired for remote equipment.

Ease of Integration. None of the equipment proposed for this flowsheet (with the exception of the evaporator) is currently employed at the INEEL for waste treatment. Thus, integrating it could cause some disruption of the current operation. Technical and operational problems of integrating high-temperature drying into the current operation would be medium.

Safety and Environmental. The baseline technology has operated safely for several decades. The high-temperature drying flowsheet employs similar reactions, and thus this safe operation would be expected to continue.

Rotary kiln operation is well understood and has a very good safety record. As long as no reductants are used in this flowsheet, problems should be limited.

Design Issues. There are no large design issues with respect to equipment availability and suitability. Some testing of the screw dryer and rotary kiln with simulant is needed to ensure full operability. There is a medium level of confidence that current designs would accomplish the tasks desired.

INEEL High-Temperature Drying Summary

Operating Suitability

Medium

Technical Availability

High

Operability

Medium

Ease of Integration Medium

Safety and Environmental Medium

Design Issues 


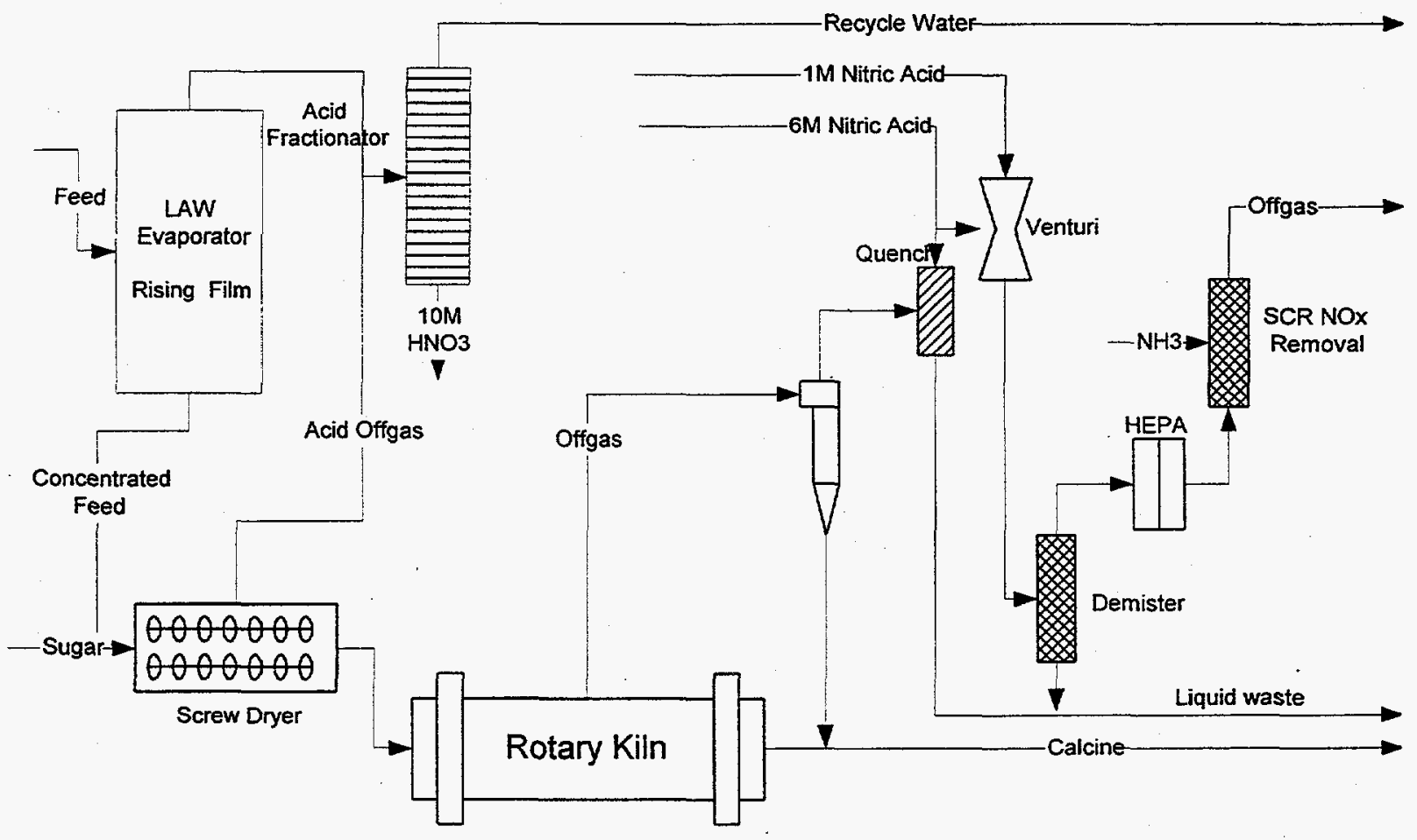

Figure 6.3. High-Temperature Drying Flowsheet

\begin{tabular}{|l|r|r|c|}
\hline & \multicolumn{1}{|c|}{ Raw Feed $^{\text {(a) }}$} & Evap. Bottoms & Calcined Product \\
\hline $\mathrm{NO}_{3}$ & $145.6 \quad 50 \%$ removal & $72.8 \quad 95 \%$ destruction & 3.6 \\
\hline $\mathrm{Al}$ & 7.7 & 7.7 & 7.7 \\
\hline $\mathrm{Na}$ & 21.5 & 21.5 & 21.5 \\
\hline $\mathrm{H}_{2} \mathrm{O}$ & $825.2 \quad 83 \%$ vol reduction & $140.3 \quad 100 \%$ removal & 0.0 \\
\hline TOTAL & $\mathbf{1 0 0 0 . 0}$ & $\mathbf{2 4 2 . 3}$ & $\mathbf{3 2 . 8}$ \\
\hline Volume, $\mathrm{kL}$ & $851.0 \quad 83 \%$ vol reduction & 144.7 & \\
\hline Density & 1.18 & 1.6 & \\
\hline (a) Basis $1000 \mathrm{~kg} / \mathrm{hr}$ raw feed. & \\
\hline
\end{tabular}

The process basis for the high-temperature drying flowsheet is similar to that of the baseline. Evaporator bottoms are fed directly to the screw dryer, which should completely evaporate all nitric acid for recycle and produce a nearly dry solid. Some inerts or recycled calcine may be needed as a drying medium. Nitrate salts will primarily be thermally decomposed in the rotary kiln. Burnout temperatures can be adjusted, and nitrate destruction to $\mathrm{NO}_{x}$ could approach $100 \%$ but will be fixed at $95 \%$. 


\subsubsection{COGEMA Direct Injection Rotary Kiln}

The COGEMA rotary kiln flowsheet

(Figure 6.4) apparently employs a rotary kiln to remove nitrate via reductive calcination directly. The apparent reductant employed in this flowsheet is sugar. Actual details of the flowsheet are unknown as the process is proprietary, but limited information was recently provided to PNNL by COGEMA. Reference to this process can be found in Wood (1997) and Sevigny (1996) as well.

Operating Suitability. The COGEMA rotary kiln flowsheet appears to meet system requirements for denitration of feedstocks. There is a high degree of similarity between the INEEL system requirements and the COGEMA technology. However, additional data should be obtained.

Technical Availability. The COGEMA rotary kiln flowsheet employs proven technology, and thus has the high probability of success from a technical standpoint. It has apparently been used in France for many years at a large scale. It should be considered very high with respect to technical availability. However, there is no other direct commercial experience for exothermic high-offgas reactions in rotary kilns.

Operability. System operability of this flowsheet is potentially much easier than operating a fluidized bed. Removing the nitrate during the calcination would eliminate the $\mathrm{NO}_{x}$ that must be removed by SCR. Rotary kilns have been shown to operate reliably for years with minimal maintenance. Substantial operating experience exists with COGEMA, which should be explored further.
Ease of Integration. None of the equipment proposed for this flowsheet is currently employed at INEEL for waste treatment. Thus, some disruption of the current operation would be expected. Technical and operational problems of integrating high-temperature drying into the current operation would be medium.

Safety and Environmental. Operation of rotary kilns is well understood and has a very good safety record. COGEMA apparently has operated rotary kiln calcination using sugar addition in France for many years. Accordingly, there would be a high level of conformance with safety and environmental issues. Further investigation should be done to better characterize these operations.

Design Issues. There are no large design issues with respect to equipment availability and suitability. Some testing of the rotary kiln with simulant is needed to ensure full operability. Based on COGEMA's purported large-scale operations, there is a high level of confidence that current designs would accomplish the tasks desired.

COGEMA Rotary Kiln Calcination Summary

Operating Suitability

High

Technical Availability

High

Operability

High

Ease of Integration

Safety and Environmental Medium

High

Design Issues 


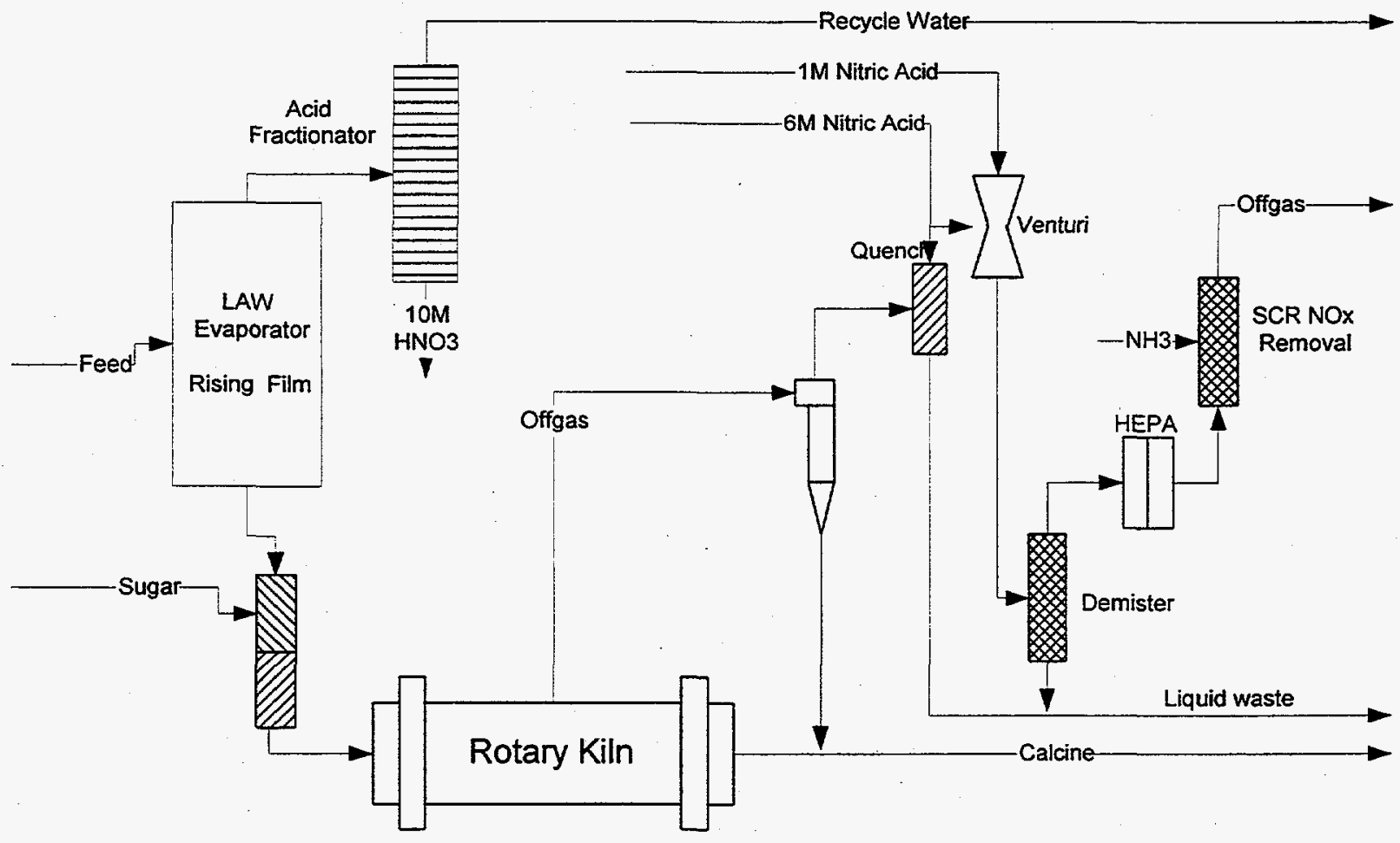

Figure 6.4. COGEMA Rotary Kiln Flowsheet

\begin{tabular}{|c|c|c|c|}
\hline & Raw Feed $^{(a)}$ & Evap. Bottoms & Calcined Product \\
\hline$\overline{\mathrm{NO}_{3}}$ & $145.6 .50 \%$ removal & $72.8 \quad 100 \%$ destruction & 0.0 \\
\hline $\mathrm{Al}$ & 7.7 & 7.7 & 7.7 \\
\hline $\mathrm{Na}$ & 21.5 & 21.5 & 21.5 \\
\hline $\mathrm{H}_{2} \mathrm{O}$ & $825.2 \quad 83 \%$ vol reduction & $140.3 \quad 100 \%$ removal & 0.0 \\
\hline TOTAL & 1000.0 & 242.3 & 29.2 \\
\hline Volume, kL & $851.0 \quad 83 \%$ vol reduction & 144.7 & \\
\hline Density & 1.18 & 1.6 & \\
\hline
\end{tabular}

The process basis assumes $100 \%$ destruction of nitrate in rotary kiln by adjusting residence time and final exit temperature. 


\subsubsection{PNNL Glycine Denitration Flowsheet}

The PNNL glycine denitration flowsheet (Figure 6.5) employs a rotary kiln to remove nitrate via reductive calcination directly. It is similar in nature to the COGEMA system, except the reductant is glycine.

Operating Suitability. The PNNL glycine denitration flowsheet appears to meet system requirements for denitration of feedstocks. There is a high degree of similarity between the INEEL system requirements and the Glycine Nitrate Process (Chick and Maupin 1995). However, only limited testing and production on specific metal nitrates has been performed. Additional data should be obtained with simulant.

Technical Availability. The PNNL glycine denitration flowsheet employs proven technology, and thus has the high probability of success from a technical standpoint. It has been used successfully by Seattle Specialty Ceramics to produce over $1000 \mathrm{~kg}$ of specialty ceramic powders. Because of the pilot-scale nature of the process, it should be considered medium with respect to technical availability.

Operability. System operability of this flowsheet is potentially much easier than operating a fluidized bed. Rotary kilns have been shown to operate reliably for years with minimal maintenance. However, direct reduction synthesis at a large scale has not been demonstrated, and it should be explored further with actual simulant. The fine particles captured during ceramic synthesis may present substantial offgas cleanup problems in a radioactive system. Operability should be considered medium.

Ease of Implementation. None of the equipment proposed for this flowsheet is currently employed at the INEEL for waste treatment.
Thus, some disruption of the current operation would be expected. Technical and operational problems of integrating the glycine nitrate process into the current operation would be medium.

Safety and Environmental. Operation of rotary kilns is well understood and has a very good safety record. As noted earlier, COGEMA apparently has operated their rotary kiln calcination using sugar addition in France for many years, and, accordingly, there would be a high level of conformance with safety and environmental issues. PNNL researchers further indicate that glycine produces a more stable reaction than sugar for reactive synthesis of ceramic powders. There is a medium level of confidence that the Glycine Nitrate Process could be operated safely in a large-scale unit. Further investigation should be done.

Design Issues. Large-scale implementation of the Glycine Nitrate Process has not been demonstrated. Some design issues must be addressed. Based on COGEMA's purported large-scale operations, there is a medium level of confidence that current designs could be adapted to the Glycine Nitrate Process and would accomplish the tasks desired.

PNNL Glycine Denitration Summary

Operating Suitability

High

Technical Availability

Medium

Operability

Medium

Ease of Integration

Medium

Safety and Environmental

Medium

Design Issues 


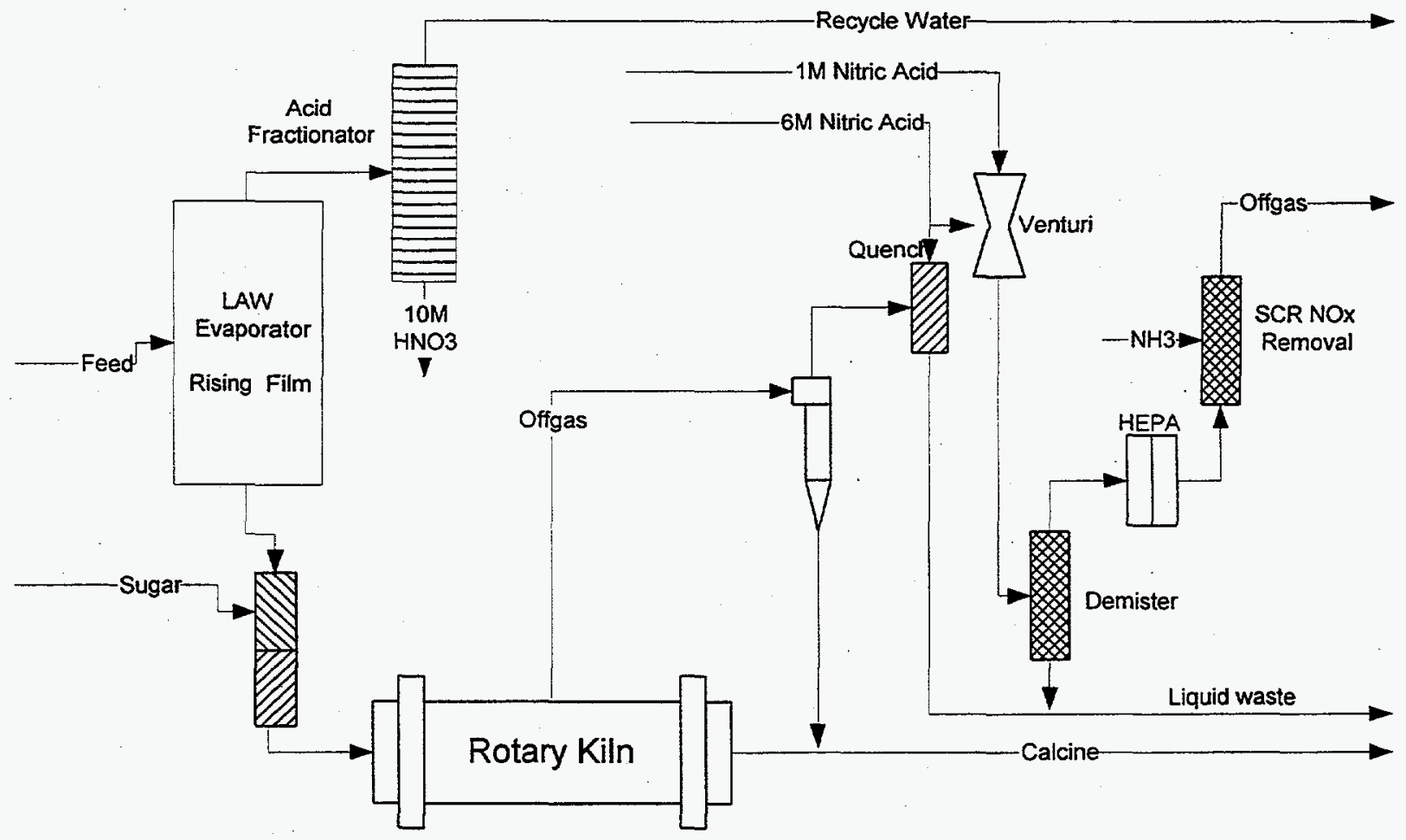

Figure 6.5. PNNL Glycine Denitration Flowsheet

\begin{tabular}{|c|c|c|c|}
\hline & Raw Feed ${ }^{(a)}$ & Evap. Bottoms & Calcined Product \\
\hline $\mathrm{NO}_{3}$ & $145.650 \%$ removal & $72.8 \quad 100 \%$ destruction & 0.0 \\
\hline $\mathrm{Al}$ & 7.7 & 7.7 & 7.7 \\
\hline $\mathrm{Na}$ & 21.5 & 21.5 & 21.5 \\
\hline $\mathrm{H}_{2} \mathrm{O}$ & $825.2 \quad 83 \%$ vol reduction & $140.3 \quad 100 \%$ removal & 0.0 \\
\hline TOTAL & 1000.0 & 242.3 & 29.2 \\
\hline Volume, $\mathrm{kL}$ & $851.0 \quad 83 \%$ vol reduction & 144.7 & \\
\hline Density & 1.18 & $\overline{1.6}$ & \\
\hline
\end{tabular}

The process basis assumes $100 \%$ destruction of nitrate in rotary kiln by adjusting residence time and final exit temperatures. 


\subsubsection{Bureau of Mines Briquette Flowsheet}

The Bureau of Mines briquette flowsheet (Figure 6.6) employs an evaporator, mixer, briquetter, and rotary kiln to sequentially remove nitrate in several stages. Concentrated waste is mixed with grouting materials and briquetted. Final calcination occurs when sugar and nitrate react within each pellet in the rotary kiln. Calcined pellets are then grouted.

Operating Suitability. As proposed, the Bureau of Mines flowsheet would meet system requirements for denitration of feedstocks. However, only limited pilot testing of this concept has been conducted.

Technical Availability. The Bureau of Mines flowsheet employs common industrial equipment and previously demonstrated technology. However, only limited pilot testing of proposed equipment has been accomplished using representative simulants. This flowsheet has a medium probability of success from a technical standpoint.

Operability. System operability of this flowsheet is potentially much easier than operating a fluidized bed. Removing most of the nitrate prior to pelletization could substantially reduce the heat of reaction in the kiln. Rotary kilns have been shown to operate reliably for years with minimal maintenance. Pellets could reduce concerns of caking and agglomeration.

Ease of Implementation. None of the equipment proposed for this flowsheet (with the exception of the evaporator) is currently employed at
INEEL for waste treatment. Thus, some disruption of the current operation can be expected. Technical and operational problems of integrating high-temperature drying into the current operation would be medium.

Safety and Environmental. Safety and environmental compatibility of the Bureau of Mines flowsheet with INEEL needs is potentially quite high. Operation of briquetters and rotary kilns is well understood and has a very good safety record. Dilution of the nitrate with inerts can better control the heat of reduction. Briquettes could ensure $100 \%$ nitrate removal and could substantially reduce particulate problems in the offgas.

Design Issues. There are no large design issues with respect to equipment availability and suitability. Large-scale processing equipment is readily available. Some testing of exact briquette mixtures and rotary kiln with simulant is needed to ensure full operability. There is a medium level of confidence that current designs would accomplish the tasks desired.

Bureau of Mines Briquette Process Summary

Operating Suitability

High

Technical Availability Medium

Operability Medium

Ease of Integration Medium Safety and Environmental High Design Issues Medium 


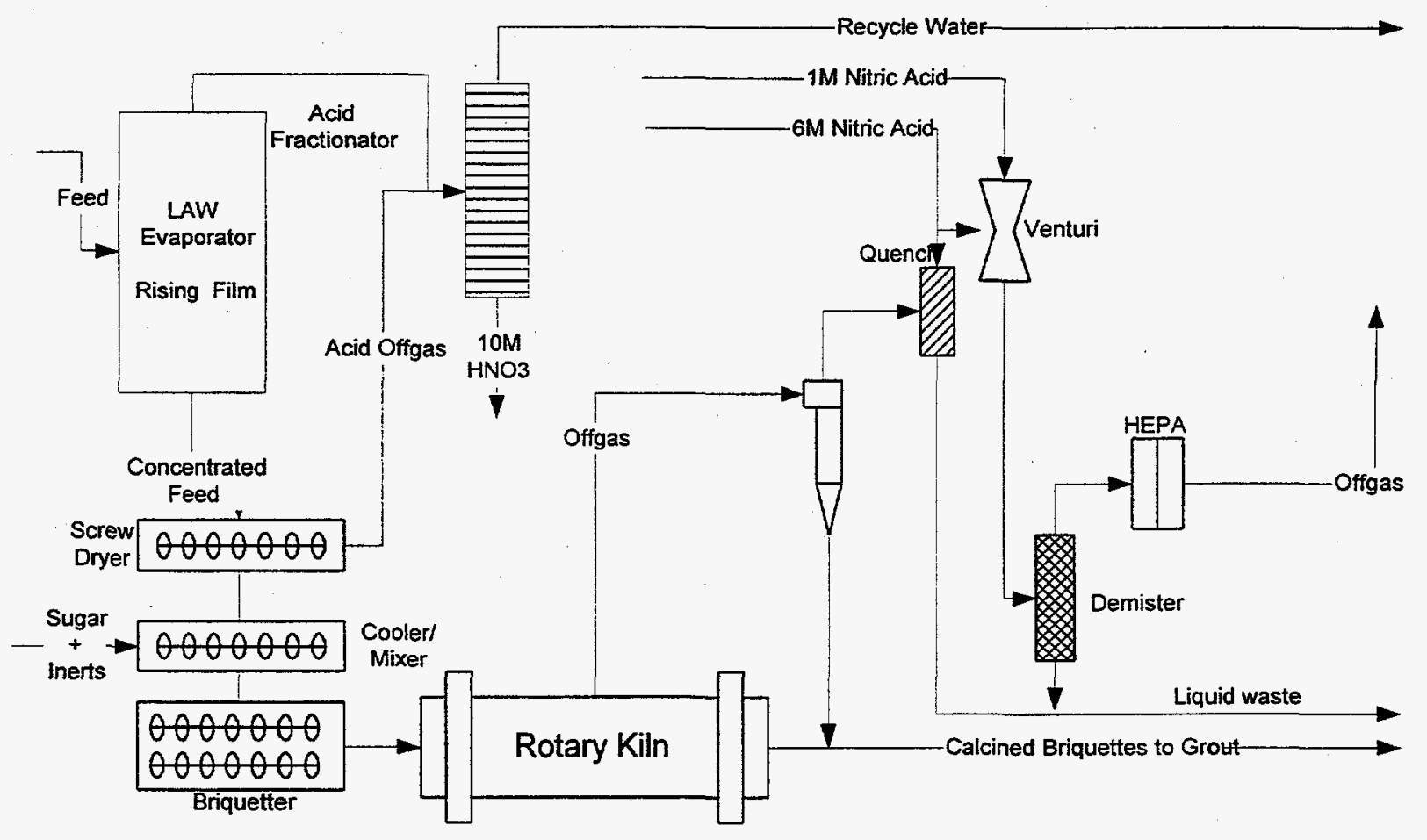

Figure 6.6. Bureau of Mines Briquette Flowsheet

\begin{tabular}{|c|c|c|c|}
\hline & Raw Feed ${ }^{(a)}$ & Evap. Bottoms & Calcined Product \\
\hline $\mathrm{NO}_{3}$ & $145.6 \quad 50 \%$ removal & $72.8 \quad 100 \%$ destruction & 0.0 \\
\hline $\mathrm{Al}$ & 7.7 & 7.7 & 7.7 \\
\hline $\mathrm{Na}$ & 21.5 & 21.5 & 21.5 \\
\hline $\mathrm{H}_{2} \mathrm{O}$ & $825.2 \quad 83 \%$ vol reduction & $140.3 \quad 100 \%$ removal & 0.0 \\
\hline TOTAL & 1000.0 & 242.3 & 29.2 \\
\hline Volume, kL & $851.0 \quad 83 \%$ vol reduction & 144.7 & \\
\hline Density & 1.18 & 1.6 & \\
\hline
\end{tabular}

The process basis for the Bureau of Mines briquette flowsheet assumes concentration of the initial feed according to the baseline. Concentrated feed is dried in a screw dryer, then mixed with an appropriate amount (yet to be determined) of grout formers, inerts, and reductant. This creates a mixture that can be made into briquettes or pellets. These pellets are then processed in a rotary kiln at a temperature sufficient to eliminate all residual nitrate.

The process basis assumes $100 \%$ destruction of nitrate in rotary kiln by adjusting residence time and final exit temperatures. 


\subsection{Engineering-Scale Equipment}

Brochures, quotes, and specifications were solicited from vendors for a variety of engineering and full industrial-scale processing equipment. Specific requests were made for equipment having operating histories with reactants similar in nature to nitrate salts and organics. During this evaluation, for chemical denitration, no industrial equipment with comparable operating history was found, with the possible exception of the COGEMA rotary kiln system located in France.

A number of industrial equipment vendors indicated experience with drying, combustion, and incineration of a variety of waste materials, including flammable solids. However, none of these situations reflected intimate mixing of the oxidant and reductant prior to reaction. Most reflected incineration of organic waste materials using air or oxygen as the oxidant. A few carried out roasting of activated carbon for regeneration purposes. There were also a multitude of endothermic ore roasting applications and cement kilns. A variety of fluidized beds, moving beds, and rotary kilns are available and well suited to these applications.

In the application discussed in this report, a large excess of oxidizing materials is to be mixed with a near-stoichiometric amount of organic, such as sugar. The reaction is similar to that undergone by "black powder" when it burns unconfined. References have been made to certain "recipes" which include sodium nitrate and carbon. The unconfined reaction of nitrates and carbon-bearing materials can be vigorous, but controllable. The key to performing this task involves either dilution of the components such that the heat of reaction is absorbed by the diluents, the addition of a poison to slow the reaction, or the immediate reaction of small amounts at high temperatures. In all cases, the most important safety issue will be maintaining an absolute minimum inventory of mixed reactants.

\subsubsection{Pretreatment Options}

Various pretreatment options are being considered that may reduce the nitrate loading on the actual denitration reactor, convert the liquids to solids for ease of handling, or dilute the reaction components. Three options that warrant further investigation are vacuum evaporation, a screw drying, and inerts mixing/briquetting.

\subsubsection{Vacuum Evaporator}

Because of the large reaction heat loading during denitration using a reductant, it is desirable to remove as much nitrate as possible in nitric acid form via distillation. The obvious choice for this unit operation is either a rising film, falling film, or scraped surface vacuum evaporator followed by a tray fractionator. Based on experiments outlined in Section 3.3, approximately $50 \%$ of the nitrate can be removed as nitric acid. Such evaporators are common unit operations equipment. 
The Fluor-Daniel (1997) Feasibility Study specified a rising-film evaporator followed by an acid recovery fractionation column containing 15 trays. This system is designed to reduce $3388 \mathrm{~L} / \mathrm{hr}$ of SBW to $565 \mathrm{~L} / \mathrm{hr}$, an $83 \%$ volume reduction. The concentration of nitrate in the denitrator feed is estimated to be about $5 \underline{\mathrm{M}}$ for the mixed calcine case. Approximately $10 \underline{\mathrm{M}}$ nitric acid is recovered in the fractionator bottoms for recycle to the process.

No other unresolved design and process issues are apparent with the vacuum evaporator and nitric acid recovery system.

\subsubsection{Screw Dryer}

In a screw dryer unit, a liquid slurry is fed and a dry granular power is produced. Other terms for this type of operation include paddle processor or thermal disk processor. The heating source is either steam or another heat transfer fluid such as DOWTHERM or equivalent. The heat transfer fluid circulates through the case of the machine and typically circulates through central paddles, disks, or screw flights as well. The purpose of these flights is not only to move the materials through the processor, but to provide extended heat transfer surface area. In fact, many of the screws or flights have a serrated surface, fins, or extensions designed to create additional surface area for heat transfer.

Design information obtained from several vendors of screw dryers or paddle processors is shown below:

Holo-Flite Thermal Processors

LIST Discotherm B

LIST ORP

LIST CRP

K-S Paddle Dryer/Processor

K-S Nara Paddle Dryer/Processor
Svedala

LIST Equipment, Inc.

LIST Equipment, Inc.

LIST Equipment, Inc.

Komline-Sanderson

Komline-Sanderson

All appear able to handle slurry drying of abrasive solids or corrosive liquids. All are available in a variety of corrosion-resistant materials and heat duties. All are capable of design and operation up to $350^{\circ} \mathrm{F}$ to $400^{\circ} \mathrm{F}$ using steam or heat transfer fluids.

Previous studies have shown that INEEL calcines have a propensity to deliquesce. Despite the ability of the screw dryers or peddle processors to dry a variety of pastes and slurries to dry powders, it is unlikely that a non-deliquescent powder can be produced from the LAW simulant feed composition. High nitrate solids typically will absorb water due to humidity in the air.

During operation, all of these processors have substantial inventory of partially dried solids at drying temperature. As shown in Section 2.0, partially dried nitrate/sugar mixtures are highly reactive and can spontaneously initiate combustion-type reactions at temperatures as low as $150^{\circ} \mathrm{C}$ to $200^{\circ} \mathrm{C}$. Because of this inherent operating weakness (large inventory of partially dried solids), this preprocessing equipment should only be considered for the INEEL high-temperature drying option where reductant is not used. 
Some limited development experience exists with radioactive wastes. INEEL currently dries a $\mathrm{NaOH}$ stream using a screw dryer. Kulichenko et al. (1984) apparently treated high aluminum and sodium wastes up to $260 \mathrm{~g} / \mathrm{L}$ of sodium nitrate with molasses in a "worm calciner" $27 \mathrm{~cm}$ in diameter and $3.6 \mathrm{~m}$ long. No temperatures or reaction conditions were available in the review of this work. Clearly this treatment would be reactive in nature, and further confirmation is needed.

\subsubsection{Inerts Mixer/Briquetter}

For the pretreatment of Hanford wastes, the Bureau of Mines (Eaton 1995) evaluated the potential of mixing grout formers, fly ash, waste materials, and reductant for total denitration and calcination in one step. Presumably, these materials would be pelletized, briquetted, prilled, or otherwise agglomerated to allow introduction into a rotary kiln. As the pellet traveled through the rotary kiln it would react as an individual pellet, thus reducing potential concerns about inventory. This feedstock would probably not be suitable for processing in a fluidized bed because of the tendency for large particulates to drop out of the fluidization. However, it may be possible to design a "moving bed" that would intentionally allow the particulates to react in a fluidized bed of solids and then migrate to the bottom of the reactor to be removed. This type of reactor has inherent safety advantages due to its large thermal mass (see Fluidized Bed discussion below).

\subsubsection{Denitration Reactor Options}

Equipment options for performing the denitration reaction include baseline fluidized bed technology currently employed at INEEL, several flowsheets utilizing a rotary kiln, and the Rocketdyne Fast Calciner Reactor. Many of these have been discussed elsewhere (Wood 1997).

\subsubsection{Fluidized Bed}

A fluidized bed is generally a heated bed of solids of a specific size that are suspended by the upward flow of gas such as air or steam. The solids can be inert or catalytic. In a fluidized bed, the solids behave like a boiling liquid and constantly redistribute, allowing very uniform temperatures and materials distribution. Because the bed itself contains a very large volume of solids, there is a built-in thermal sink that can absorb large heats of reaction. For this reason, highly exothermic reactions such as incineration are commonly done in fluidized beds.

An excellent summary of radioactive waste calcination in fluidized beds is given by Eldredge (1991) and Boardman (1997). Zenz and Othmer (1960) provide the definitive treatise on fluid bed design.

The INEEL baseline flowsheet employs a high-temperature fluidized bed for denitration. The unit is expected to be fired with kerosene and oxygen and operated at $650^{\circ} \mathrm{C}$ and assume a nitrate removal of 92\% (Fluor-Daniel 1997). The INEEL baseline+sugar flowsheet employs the same fluidized bed denitrator, but injects a reductant such as sugar into the bed. Operation at lower temperature $\left(400^{\circ} \mathrm{C}\right.$ to $500^{\circ} \mathrm{C}$ ) is likely. 
Heyl \& Patterson and Dorr-Oliver (KTI) were contacted to identify any commercial application of fluidized beds for treating nitrates. While fluidized beds are well known for processing exothermic reactions, neither of these vendors had specific processing examples where both oxidant and reductant were intimately mixed before being added to the fluidized bed. Traditional uses of fluidized beds include catalytic cracking, combustion, gasification, catalytic reforming, and several others. Generally, the reaction occurs on the surface of the catalyst, or the reaction uses air or steam in the fluidizing gas.

Because of the exothermic nature of the nitrate-sugar reactions, a fluidized bed may be particularly well suited for mitigating the thermal effects of the reaction. Fluidized beds have unusually good temperature consistency and high heat transfer. Fluidized beds also have extremely high thermal mass and inertia, thus minimizing the effects of a short-term reaction excursion.

\subsubsection{Rotary Calciner}

Rotary kilns have been used for decades to process a variety of ores, make lime, and incinerate trash, among hundreds of other uses. They are simple, relatively inexpensive, easy to operate and control, and capable of processing extremely large material flow rates. Rotary kilns in general are large, rotating hot tubes. They are either direct-fired into the kiln with natural gas or kerosene, or are indirectly heated through the tube wall by gas, kerosene, heat transfer fluid, or even electricity.

The COGEMA Rotary Kiln, PNNL Glycine Nitrate, and Bureau of Mines flowsheets all employ a rotary kiln in a variety of configurations. The rotary kiln denitrifies and then calcines the nitrate salt at $600^{\circ} \mathrm{C}$ to $700^{\circ} \mathrm{C}$.

A rotary kiln could be used in full-scale application of the PNNL glycine denitration process. In this process, liquid waste and glycine are sprayed onto the hot wall of an indirectly fired rotary kiln. The mixture dries, ignites, and drops into the sweep gas stream.

Another alternative would be to mix the concentrated waste slurry with grout formers and flyash in a proportion sufficient to pelletize or briquette the mixture. This was previously done by Eaton (1995) when investigating the denitration of Hanford waste prior to glassification. These particles would then be heated in the rotary kiln until they ignited, much like a charcoal briquette. After the appropriate residence time, they would be discharged, ground up, and grouted. One advantage of this alternative would be the limited amount of fine particulate in the offgas. Another potential advantage might be the ease of thermal control, the reduced chances of a runaway reaction, and high burnout rates.

Several vendors and researchers were contacted to determine if any commercial applications of nitrate destruction or related reactions were available:

Heyl \& Patterson, Inc.

Louisville Drying Machinery

Allis Mineral Systems

Fuller Company

Summit Valley Equipment 
Dorr-Oliver (KTI)

Vulcan Iron Works, Inc.

No commercial applications were discovered, with the possible exception of COGEMA's rotary kiln nuclear waste calciner in France and ceramics manufacture using the PNNL Glycine Nitrate Process.

PNNL's Glycine Nitrate Process has been producing commercial quantities of highly pure ceramics at Seattle Specialty Ceramics (now ProxAir) for about 3 years. During that time, a small production unit has operated over $1000 \mathrm{hr}$ and produced about $1000 \mathrm{~kg}$ of specialty powders. The pilot plant (Figure 6.7) (located at PNNL) could be set up to process LAW simulant using both sugar and glycine as reductants.

From the limited discussions with COGEMA, it appears that their units may actually employ sugar denitration of waste directly within a rotary kiln. Limited references to this technology were found (Sevigny 1996, Wood 1997), and discussions indicate that data are proprietary. These references discuss a calciner that appears capable of processing $70 \mathrm{~L} / \mathrm{hr}$ using a $30-\mathrm{cm}$-diameter rotary kiln approximately $3 \mathrm{~m}$ long. The kiln is reputed to operated at $400^{\circ} \mathrm{C}$ and use reductive calcination by the addition of organics.

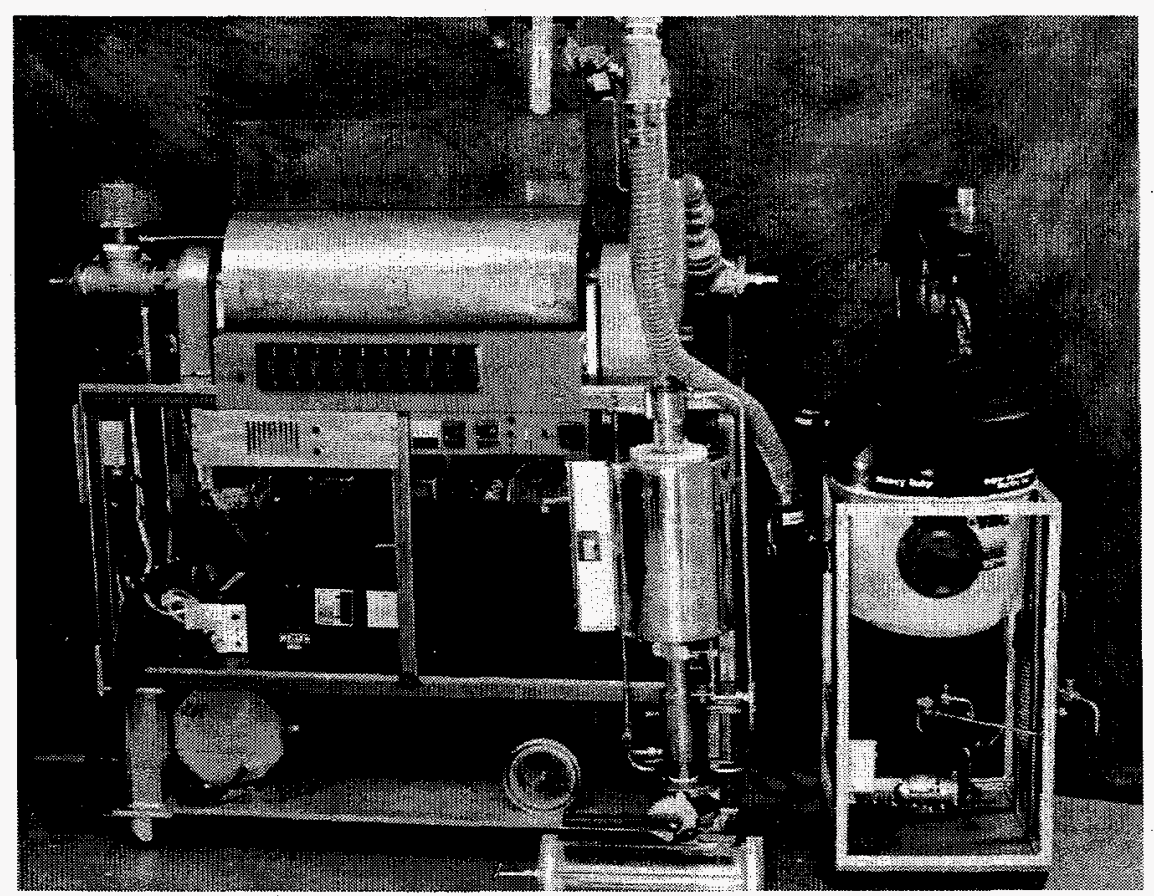

Figure 6.7. Glycine Nitrate Process Pilot Plant 


\subsubsection{Rocketdyne Fast Calciner}

In the early 1980s the Rocketdyne.division of Rockwell International developed several spinoffs from their liquid rocket and advanced coal combustor technologies that were directed at calcination of both high- and low-level radioactive wastes. This technology drew on their 40 years of rocket engine experience and 10 years of coal combustion and acetylene production. The early spray calciner reactor technology was improved through a series of pilot tests using a variety of feeds, including Hanford Tank 101SY simulant. The resulting technology is referred to as the Rocketdyne Fast Calcination Reactor.

Both the spray calciner and fast calcination reactor schematics depict a commercial technology that can be adapted to the needs of the INEEL flowsheet. While high-temperature calcination could be accomplished fairly easily, it would still produce substantial amounts of $\mathrm{NO}_{\mathrm{x}}$. Some development work would be needed to confirm the ability to safely use sugar or other reductant in this configuration.

\subsubsection{Offgas Treatment}

Final treatment of the offgas will require several stages of particulate removal, possibly $\mathrm{NO}_{\mathrm{x}}$ destruction, some type of cooling/scrubbing, and final HEPA filtration prior to release. Each flowsheet will have differing offgas production rates and particulate loadings. For example, high levels of sweep gases from the INEEL Fluidized Bed System, PNNL glycine denitration, or the Rocketdyne Fast Calciner will greatly increase offgas treatment requirements, while thermal treatment of briquettes, pellets, or other agglomerates in a rotary kiln might tend to have less offgas requiring treatment.

The nitrate-organic reactions are quite vigorous and tend to produce oxide particulates. In fact, the Glycine Nitrate Process, as practiced by Seattle Specialty Ceramics (now ProxAir), produced fine ceramic powders of very specific compositions by manipulating various nitrate salts. These fine powders are evidence that denitration proceeds quickly and mostly to nitrogen gas. Fine powders produced by subjecting LAW or other LLW (which contain some level of radionuclides) to the Glycine Nitrate Process may also present some difficulty with regard to offgas cleanup.

Rough particulate removal is accomplished by several stages of high efficiency cyclone separators, a high-temperature fabric filter baghouse, an electrostatic precipitator, or other similar devices. Following particulate removal, the gas stream must be cooled, generally by injecting water or other recycled dilute acid. The bulk of sub-micron particulate is not removed by normal equipment and must be captured in final HEPA filters prior to release.

All Fluor-Daniel flowsheets typically include an SCR step for final destruction of $\mathrm{NO}_{\mathrm{x}}$. This process reacts any residual $\mathrm{NO}_{\mathrm{x}}$ with ammonia over a sodium mordenite catalyst at elevated temperatures and must be done directly after the denitration reactor or calciner in the flowsheet. Typically, the reaction is done in two stages so that excess ammonia is not added. 


\subsection{Engineering Recommendations}

Several flowsheets appear to have sufficient development and operational experience to be useful for denitration of INEEL waste streams. The addition of sugar to the baseline flowsheet could substantially reduce $\mathrm{NO}_{\mathrm{x}}$ emissions and therefore reduce capital and operating costs significantly. Further work at the pilot scale or larger is need to fully characterize the addition of organics to the fluidized bed.

Of the other options evaluated, the COGEMA technology should be evaluated thoroughly as soon as possible. The COGEMA rotary kiln is potentially the most industry-ready technology. Following that, both the baseline+sugar flowsheet and the Bureau of Mines briquette flowsheet appear to meet the system requirements better than the high-temperature thermal systems. Their development should be carefully weighed against the substantial operating issues surrounding selective catalytic reduction of $\mathrm{NO}_{\mathrm{x}}$ required in the thermal destruction flowsheets.

The Bureau of Mines briquetting flowsheet is an elegant flowsheet with inherent safety features. It matches very well with INEEL requirements and uses off-the-shelf equipment. Some limited modeling or simulant work should be done to determine optimum pellet size and waste loading.

The PNNL Glycine Nitrate Process is intriguing and very similar to the COGEMA kiln process. This process has been used commercially for several years to make ceramic powders. It should be closely evaluated and compared to the COGEMA activities.

The high-temperature drying flowsheet has the advantage of removing essentially all of the nitric acid prior to thermal denitration. The remaining sodium nitrate will decompose to $\mathrm{NO}_{\mathrm{x}}$, which must be selectively oxidized in the SCR unit. Essentially $100 \%$ of the nitrate can be calcined in the rotary kiln.

The Rocketdyne Fast Calciner is a novel concept and likely would meet all of the system requirements given enough developmental time. However, it is unlikely that such funding or time is available for this application. In addition, the large volume of offgas generated is seen as a potential integration problem. This technology should be dropped from consideration. 


\subsection{References}

Beitel, G. A. 1976a. Chemical Stability of Salt Cake in the Presence of Organic Materials. ARH-LD119, Atlantic Richfield Hanford Company, Richland, Washington.

Beitel, G. A. 1976b. Sodium Nitrate Combustion Limit Tests. ARH-LD-123, Atlantic Richfield Hanford Company, Richland, Washington.

Beitel, G. A. 1977. Exothermic Potential of Sodium Nitrate Salt Cake. ARH-LD-163, Atlantic Richfield Hanford Company, Richland, Washington.

Bray, L. 1963. Denitration of PUREX Wastes with Sugar. HW-76973 Rev., Hanford Laboratories, General Electric Company, Richland, Washington.

Chick, L. A., and G. D. Maupin. 1995. CRADA with Seattle Specialty Ceramics (SSC) and Pacific Northwest National Laboratory (PNL-011): Synthesis and Processing of Ceramic Powder Materials Using the Glycine/Nitrate Process. PNL-10824, Pacific Northwest National Laboratory, Richland, Washington.

Eaton, W. C. 1995. U.S. Bureau of Mines, Phase 1 Hanford Low-Level Waste Melter Tests: Final Report. WHC-SD-WM-VI-030, Rev. 0, Westinghouse Hanford Company, Richland, Washington.

Eldredge, A. B. 1991. "The Soldis Mixing Model for Scale-Up of the Fluidizer Bed Calcination Process." Ph.D. Dissertation, Department of Chemical Engineering, University of Idaho.

Kulichenko, V. V., V. A. Savel'ev, V. A. Prokhodtsev, and A. A. Ryabova. 1984. "Calcination of Model High-Level Wastes in a Horizontal Apparatus." Soviet Atomic Energy 56(5): 314-318.

Meile, L. J., and A. J. Johnson. 1984. Waste Generation Reduction - Nitrates FY 1983 Status Report. RFP-3619, DOE/TIC-4500 (Rev. 72), Rockwell International, Golden, Colorado.

Ryan, J. L. 1995. Redox Reactions and Foaming in Nuclear Waste Glass Melting. PNNL-10510, Pacific Northwest Laboratory, Richland, Washington.

Sevigny, G. 1996. Evaluation of Dryer/Calciner Technologies for Testing. PNNL-10979, Pacific Northwest National Laboratory, Richland, Washington.

Smith, H. D., E. M. Tracey, J. G. Darab, and P. A. Smith. 1996. Hanford Low-Level Waste Process Chemistry Testing Data Package. PNNL-1 1046, Pacific Northwest National Laboratory, Richland, Washington.

Zenz, F. A., and D. F. Othmer. 1960. Fluidization and Fluid Particle Systems. Reinhold Chemical Engineering Series. New York. 


\subsection{Supporting Documents}

Barnes, C. M., D. D. Taylor, and B. R. Helm. 1997. Process Basis Information for the Feasibility Study of the Preferred Alternative for the Treatment of ICCP SBW, Calcine, and LLW. CMB-01-97, Lockheed Martin Idaho Technologies Company, INEEL, Idaho Falls, Idaho.

Boardman, R. E. 1997. Alternative Calcination Development Status Report. Lockheed Martin Idaho Technologies Company, INEEL, Idaho Falls, Idaho.

Fluor-Daniel. September 1994. Low Level Waste Grout Pilot Plant-Conceptual Design Report. Contract \#04435308, Richland, Washington.

Fluor-Daniel. December 1997. ICPP Waste Treatment Facilities Feasibility Study Report. Contract \#04435336, Richland, Washington.

Marshall, D. W., and R. C. Green. 1996. The Report on the Sugar Nitrate Interaction and Sugar-Calcine Reactivity Study. DWM-03-96, Lockheed Martin Idaho Technologies Company, INEEL, Idaho Falls, Idaho.

Wood, R. A. 1997. Transmittal of Cursory Evaluation of HAW and LAW Conditioning Technologies Report. RAW-01-97, Lockheed Martin Idaho Technologies Company, INEEL, Idaho Falls, Idaho. 
Appendix A

\section{Review of Denitration Chemistry}




\section{Appendix A}

\section{Review of Denitration Chemistry}

A variety of thermal, chemical, and thermochemical denitration methods are reviewed here. Thermal denitration uses high temperatures (in excess of $500^{\circ} \mathrm{C}$ ) to decompose the nitrate and nitrite compounds in the waste stream. Chemical denitration uses chemical reductants such as formic acid to decompose the nitrates and nitrites while keeping temperatures low $\left(100^{\circ} \mathrm{C}\right)$. Thermochemical denitration uses a combination of both methods. Note: References cited in this appendix can be found in Appendix D.

\section{A.1 Thermal Denitration}

Thermal decomposition of sodium nitrate and sodium nitrite uses temperatures exceeding $500^{\circ} \mathrm{C}$ to denitrate waste. A variety of studies have been performed on thermal denitration, and various large scale denitration methods currently exist. These thermal denitration methods produce offgases that generally consist of $\mathrm{N}_{2} \mathrm{O}, \mathrm{N}_{2}, \mathrm{O}_{2}$, and $\mathrm{NO}$, but the relative amounts are dependent on the test or operating conditions. The relative amount of nitrate or nitrite destruction is also dependent on the test or operating conditions.

The decomposition of $\mathrm{NaNO}_{3}$ to $\mathrm{NaNO}_{2}$ is the first step in nitrate decomposition and begins at approximately $500^{\circ} \mathrm{C}$ (Ryan 1994; Hoshino et al. 1981; Bond and Jacobs 1966; Chun 1977):

$$
\mathrm{NaNO}_{3} \longleftrightarrow \mathrm{NaNO}_{2}+1 / 2 \mathrm{O}_{2} \uparrow
$$

The reaction rate is the same for either an oxygen or argon atmosphere (Bond and Jacobs 1966) and reaches equilibrium within two hours at $700^{\circ} \mathrm{C}$ (Burger et al. 1973). The reaction is endothermic (Bond and Jacobs 1966).

The decomposition of sodium nitrite, either as the starting compound or as an intermediate in sodium nitrate destruction, is not as clear. Bond and Jacobs (1966) studied the isothermal decomposition of sodium nitrate between $570^{\circ} \mathrm{C}$ and $760^{\circ} \mathrm{C}$ using a thermobalance in flowing $(100 \mathrm{ml} / \mathrm{min})$ argon or air. As discussed previously, the authors concluded that the first step in the decomposition of sodium nitrate is the production of sodium nitrite and oxygen. The next step is the decomposition of sodium nitrite. The authors proposed the following reactions:

$$
\begin{aligned}
& 2 \mathrm{NaNO}_{2} \longleftrightarrow \mathrm{Na}_{2} \mathrm{O}+\mathrm{N}_{2} \uparrow+3 / 2 \mathrm{O}_{2} \uparrow \\
& 2 \mathrm{NaNO}_{2} \longleftrightarrow \mathrm{Na}_{2} \mathrm{O}+2 \mathrm{NO} \uparrow+1 / 2 \mathrm{O}_{2} \uparrow
\end{aligned}
$$


Relation A.2 was concluded to be the major reaction since only a small amount of NO was formed. Because the reaction products and reaction rates are independent of the atmosphere, the authors concluded that atmospheric oxygen does not participate in the reaction. They proposed a mechanism that involves a superoxide ion as an intermediate. Activation energies and rate equations were also determined for Relations A.1 and A.2.

Burger et al. (1973) used the results of the Bond and Jacobs (1966) studies to calculate the time for $90 \%$ completion of the $\mathrm{NaNO}_{2}$ decomposition as a function of temperature. According to their calculations, at a temperature of $700^{\circ} \mathrm{C}$, it should take 132 minutes for $90 \%$ completion, and at a temperature of $850^{\circ} \mathrm{C}$, the same reaction should take 9 minutes. Based on these data, it was calculated that heating to $830^{\circ} \mathrm{C}$ for a maximum of 30 minutes would be sufficient for complete decomposition of sodium nitrate or sodium nitrite. To verify that heating to $800^{\circ} \mathrm{C}$ would be sufficient to decompose sodium nitrate or sodium nitrite, Burger et al. (1973) ran a series of experiments in which $20 \mathrm{~g}$ of sodium nitrate was placed in crucibles. The crucibles were held in a furnace set at 700 to $850^{\circ} \mathrm{C}$ for times ranging from 100 to 1070 minutes. After 1070 minutes at $700^{\circ} \mathrm{C}, 65.2 \%$ of the original $\mathrm{NaNO}_{3}$ remained, and after 240 minutes at $850^{\circ} \mathrm{C}, 7.1 \%$ of the $\mathrm{NaNO}_{3}$ remained. These experiments indicated that $\mathrm{NaNO}_{3}$ decomposition is much slower and less complete at a temperature of $800^{\circ} \mathrm{C}$ than indicated by Bond and Jacobs (1966).

Abe et al. (1983) examined sodium nitrite decomposition in an argon atmosphere at a heating rate of $5^{\circ} \mathrm{C} / \mathrm{min}$. Sodium nitrite was heated to $600^{\circ} \mathrm{C}$, and the distribution of the sodium between the reaction products of $\mathrm{Na}_{2} \mathrm{O}, \mathrm{NaNO}_{3}, \mathrm{NaNO}_{2}$ was determined. Unlike Bond and Jacobs (1966), the authors reported an effect of the atmosphere on the reaction pathways. In an argon atmosphere, sodium nitrite decomposed at about $450^{\circ} \mathrm{C}$ to form equimolar amounts of sodium nitrate and sodium oxide with a concomitant generation of NO. In an oxygen atmosphere, sodium nitrite reacted with $\mathrm{O}_{2}$ at about $400^{\circ} \mathrm{C}$ to form sodium nitrate and decomposed to form sodium oxide above $500^{\circ} \mathrm{C}$. The authors proposed the following reactions:

$$
\begin{aligned}
3 \mathrm{NaNO}_{2} \longleftrightarrow \mathrm{NaNO}_{3}+\mathrm{Na}_{2} \mathrm{O}+2 \mathrm{NO} \uparrow & \text { (in argon) } \\
2 \mathrm{NaNO}_{2}+\mathrm{O}_{2} \uparrow \stackrel{\text { (in oxygen) }}{\longleftrightarrow} 2 \mathrm{NaNO}_{3} & \text { (in }
\end{aligned}
$$

These may be considered as intermediate reactions for the overall destruction of $\mathrm{NaNO}_{2}$ to $\mathrm{Na}_{2} \mathrm{O}$, and it is expected that heating to higher temperatures would lead to the complete destruction of sodium nitrate and sodium nitrite.

Hoshino et al. (1981) studied the decomposition of sodium nitrate using thermal analysis, gas analysis, and chemical analysis. Sodium nitrite $(80 \mathrm{mg})$ was weighed in a reaction vessel and was heated to $900^{\circ} \mathrm{C}$ at 5 or $20^{\circ} \mathrm{C} / \mathrm{min}$. Argon $(50 \mathrm{ml} / \mathrm{min})$ was used as the carrier gas. Unlike Bond and Jacobs (1966), very little $\mathrm{N}_{2}$ was formed. Thermal decomposition of sodium nitrate started at $450^{\circ} \mathrm{C}$, and the gases formed were $\mathrm{O}_{2}, \mathrm{NO}$, and $\mathrm{N}_{2}\left(\mathrm{~N}_{2}\right.$ only over $\left.680^{\circ} \mathrm{C}\right)$. The overall decomposition was exothermic. Decomposition started with the production of oxygen and sodium nitrite as discussed above. 
Relation A.3 was proposed as the main reaction for the decomposition of sodium nitrite, which occurred through several possible intermediate reactions involving sodium peroxide.

Sodium peroxide, $\mathrm{Na}_{2} \mathrm{O}_{2}$, has also been reported to be a possible product of sodium nitrate and sodium nitrite decomposition (Quinn 1911; Bond and Jacobs 1966; Hoshino et al. 1981). Sodium peroxide was reported to begin to decompose at $280^{\circ} \mathrm{C}$, fuse at $510^{\circ} \mathrm{C}$, and exist as a heterogeneous mixture with $\mathrm{Na}_{2} \mathrm{O}$ between $510^{\circ} \mathrm{C}$ and $545^{\circ} \mathrm{C}$. Above $545^{\circ} \mathrm{C}$, sodium peroxide decomposes to $\mathrm{O}_{2}$ and $\mathrm{Na}_{2} \mathrm{O}$ (Rode and Golder 1956). But Burger et al. (1973) found that it was stable even at high temperatures. Burger et al. (1973) found evidence of $\mathrm{H}_{2} \mathrm{O}_{2}$ in water leaches from holding $\mathrm{NaNO}_{3}$ at $850^{\circ} \mathrm{C}$ for 4 hours, which indicates the presence of $\mathrm{Na}_{2} \mathrm{O}_{2}$ in the melt. Abe et al. (1983) also proposed that $\mathrm{Na}_{2} \mathrm{O}_{2}$ is formed in the melt under an argon atmosphere, but only as an intermediate.

Chun (1977) performed thermal gravimetric analysis (TGA) on sodium nitrate (400 mg) with maximum temperature of $950^{\circ} \mathrm{C}$ and a heating rate of 3 to $4^{\circ} \mathrm{C} / \mathrm{min}$. Air was used as the carrier gas. Then samples were heated to $1100^{\circ} \mathrm{C}$ in the furnace and held for 3 hours. Sodium nitrate began to lose weight at $588^{\circ} \mathrm{C}$. The total weight loss was $93 \%$ when heated up to $1100^{\circ} \mathrm{C}$ and $67.7 \%$ when heated to $940^{\circ} \mathrm{C}$. The theoretical weight loss, assuming all of the sodium nitrate converts to sodium oxide $\left(\mathrm{Na}_{2} \mathrm{O}\right)$, is $63.5 \%$. Chun (1977) concluded that the discrepancy between the observed weight loss and the theoretically predicted weight loss was due to the volatilization of sodium nitrate, which was previously reported to occur by Newby and Dickerson (1972).

Sodium nitrate and sodium nitrite have also been reported by Burger et al. (1973) to volatilize. It was observed that a large fraction of the material vaporized at a temperature of approximately $650^{\circ} \mathrm{C}$ during their experiments. The solid product that vaporized was mainly sodium nitrite, but also contained some sodium nitrate and sodium oxide. The solid that formed in the gas phase was extremely fine and could be carried through several feet of tubing at low gas flow rates.

The use of a plasma-torch-fired cupola test system was used to denitrate high-level radioactive waste simulant by calcination at Hanford (Gass et al. 1993). Calcination destroyed $95 \%$ of the nitrates and nitrites, producing offgases consisting primarily of $\mathrm{N}_{2}$ and $\mathrm{O}_{2}$ with low concentrations of $\mathrm{NO}_{x}, \mathrm{CO}$, and $\mathrm{CO}_{2}$. The waste volume reduction was $80 \%$. Temperatures of the crucible ranged from 900 to $1000^{\circ} \mathrm{C}$.

\section{A.2 Chemical Denitration}

Denitration can be performed at lower temperatures through chemical additions to the waste stream. Chemical denitration removes nitrates and nitrites or free nitric acid through the use of one or several reducing agents, such as formic acid. As was the case for thermal denitration, nitrates and nitrites can be chemically decomposed to $\mathrm{N}_{2}, \mathrm{~N}_{2} \mathrm{O}, \mathrm{NO}$, and $\mathrm{NO}_{2}$, with the relative amounts of these gases depending on the reductant used and the experimental conditions. Chemical denitration also reduces the amount of nitrates by driving hydrolysis reactions (Orebaugh 1976). For example,

$$
2 \mathrm{Fe}\left(\mathrm{NO}_{3}\right)_{3}+9 \mathrm{HCOOH} \longleftrightarrow 2 \mathrm{Fe}(\mathrm{OH})_{3}+6 \mathrm{NO} \uparrow+9 \mathrm{CO}_{2} \uparrow+6 \mathrm{H}_{2} \mathrm{O} \uparrow
$$


Other easily hydrolyzable cations include mercury and zirconium.

The three most commonly used reducing agents are formic acid, formaldehyde, and sugar. Other reducing agents include carbon in its elemental and other forms (coke, coal, graphite, or starch) and other organic compounds such as citric acid, ethylenediaminetetraacetic acid (EDTA), and glycolic acid. The degree of denitration depends on the salt content and the amount of hydrolyzable species.

Generally, an induction time is present before chemical denitration. The four main parameters that influence the induction time are temperature, pressure, respective concentrations, and salt concentration. At room temperatures, induction times ranged from 4 to 10 minutes during chemical denitration in which formic acid was the reductant. Ratios of reducing acid to nitrate ranged from 9.2 to 1.8 , respectively (Cecille and Kelm 1986).

\section{A.2.1 Formic Acid and Formaldehyde}

Formic acid has been shown in extensive studies to be an effective reducing agent (Meile and Johnson 1983; Cox et al. 1992; Brickford et al. 1991; Burril 1987; Cecille and Kelm 1986; Holze et al. 1979; Kelm et al. 1980; Kubota et al. 1979; Orebaugh 1976). The reactions between formic acid and sodium nitrate are numerous and depend on the acidity of the solution and relative concentrations of the reductant and salt. The stoichiometric reaction between the nitrate anion and formic acid is given by the following relationship (Meile and Johnson 1984):

$$
2 \mathrm{NO}_{3}^{-}+2 \mathrm{HCOOH} \longleftrightarrow 2 \mathrm{NO}_{2}^{-}+2 \mathrm{CO}_{2} \uparrow+2 \mathrm{H}_{2} \mathrm{O} \uparrow
$$

When formic acid is in excess, several reactions may occur:

$$
\begin{gathered}
2 \mathrm{NO}_{3}^{-}+5 \mathrm{HCOOH} \longleftrightarrow \mathrm{N}_{2} \uparrow+5 \mathrm{CO}_{2}+4 \mathrm{H}_{2} \mathrm{O} \uparrow+2 \mathrm{OH}^{-} \\
2 \mathrm{NO}_{3}^{-}+8 \mathrm{HCOOH} \longleftrightarrow 2 \mathrm{NH}_{3} \uparrow+8 \mathrm{CO}_{2} \uparrow+4 \mathrm{H}_{2} \mathrm{O} \uparrow+2 \mathrm{OH}^{-} \\
2 \mathrm{NO}_{3}^{-}+3 \mathrm{HCOOH} \longleftrightarrow 2 \mathrm{NO} \longrightarrow 3 \mathrm{CO}_{2} \uparrow+2 \mathrm{H}_{2} \mathrm{O} \uparrow+2 \mathrm{OH}^{-} \\
2 \mathrm{NO}_{3}^{-}+4 \mathrm{HCOOH} \longleftrightarrow \mathrm{N}_{2} \mathrm{O} \uparrow+4 \mathrm{CO}_{2} \uparrow+3 \mathrm{H}_{2} \mathrm{O} \uparrow+2 \mathrm{OH}^{-}
\end{gathered}
$$

When the formic acid is limited, a different mechanism of denitration occurs:

$$
2 \mathrm{NO}_{3}^{-}+\mathrm{HCOOH} \longleftrightarrow 2 \mathrm{NO}_{2} \uparrow+\mathrm{CO}_{2} \uparrow+2 \mathrm{OH}^{-}
$$

Similar equations can be written in the acidic form. Formic acid denitration is generally a violent reaction and must be controlled by the rate of acid addition. Excessive foaming has also been a problem. This has been avoided by slowly adding concentrated formic acid into boiling waste solution under a purge of inert gas. 
Depending on the relative concentrations of nitrate and the reductant, different offgases will be produced. Cecille and Kelm (1986) reviewed the addition of formic acid to boiling nitric acid and sodium nitrate (limited formic acid) and the addition of sodium nitrate and nitric acid to boiling formic acid (excess formic acid). The first scenario gave an offgas composition of $68 \% \mathrm{NO}, 4 \% \mathrm{NO}_{2}$, and $28 \% \mathrm{~N}_{2} \mathrm{O}$, whereas that of the second consisted of $22 \% \mathrm{NO}, 3 \% \mathrm{NO}_{2}$, and $75 \% \mathrm{~N}_{2} \mathrm{O}$. Carbon dioxide generation was not determined. Denitration rate and reaction mechanisms will also be dependent on temperature, pressure, purge gas, and other compounds, such as noble metals, in the reaction solution.

Kelm et al. (1980) studied formic acid denitration by adding the waste solution to boiling formic acid and boiling $\left(100\right.$ to $\left.102^{\circ} \mathrm{C}\right)$ under reflux to form $\mathrm{N}_{2} \mathrm{O}$ and $\mathrm{CO}_{2}$ as the primary products with 80 to $90 \%$ of the nitric acid being decomposed. Waste solutions were added slowly under reflux conditions to a stoichiometric amount of boiling formic acid. The reaction was completed in 3 hours after the final waste addition. Holze et al. (1979) also studied the addition of waste solutions containing nitric acid to boiling formic acid. From their work, kinetic expressions valid for a wide range of concentrations were established. These kinetic studies indicated that scheme A.11 was predominant over most of the reaction, with scheme $\mathrm{A} .10$ becoming more significant towards the end of the reaction.

Several studies have shown that increasing the salt content improves the denitration rate and decreases the induction time in acidic waste solutions. Cecille and Kelm (1986) determined that the last $20 \%$ of nitric acid will be destroyed very slowly in the presence of formic acid. With sodium nitrate, the reaction will be completed in 2 hours. Kubota et al. (1979) examined the effects of nitrite addition to the denitration process. The nitrite addition reduced the induction period to almost zero, and the maximum gas evolution rate to less than $60 \%$ of that obtained in the absence of nitrite. Induction times for denitration with formic acid can be reduced to a few seconds by adding sodium nitrite and operating at the boiling point of the system (Cecille and Kelm 1986; Kubota et al. 1979). The addition of sodium nitrite also reduces the maximum gas evolution rate (Kubota et al. 1979).

Cox et al. (1992) reported thermochemical nitrate destruction at high temperature ( 300 to $350^{\circ} \mathrm{C}$ ) under basic conditions in a batch reactor using formate as the reducing agent. Three moles of formate were added per mole of nitrate. After 2 hours of digestion, it was found that 74 to $99 \%$ of the original nitrate was destroyed, with $\mathrm{N}_{2} \mathrm{O}$ and $\mathrm{N}_{2}$ being detected in the offgas.

Formaldehyde denitration has also been extensively studied (Meile and Johnson 1984; Cecille and Kelm 1986; Evans 1959; Forsman and Oberg 1963). An intermediate in the formaldehyde denitration is formic acid; therefore, the reaction pathways for formic acid and formaldehyde denitration are similar. The resulting offgases for formic and formaldehyde are also practically identical (Cecille and Kelm 1986).

Sugar was investigated as an alternate reductant for the acidic waste in the Plutonium Uranium Extraction (PUREX) pilot plant (Bray and Martin 1962; Bray 1963). In laboratory studies, sucrose, fructose, glucose, and crude syrups rapidly and controllably decomposed $\mathrm{HNO}_{3}$ in aqueous solutions at $85^{\circ} \mathrm{C}$. Approximately 12 to 20 moles of $\mathrm{HNO}_{3}$ are destroyed per mole of sucrose as the iron content of the solution varied from 0.0 to 1.0 moles of iron. In pilot scale studies performed by Coppinger (1963), sugar was added continuously to hot waste at $100^{\circ} \mathrm{C}$, and the solution was digested for 12 hours. Twenty 
moles of nitric acid were destroyed per mole of sugar. The reaction proceeded smoothly and was easily controlled. An induction period of 6 minutes was also observed. The addition of nitrite did not reduce the induction period.

\section{A.2.2 Glycolic Acid and Citric Acid}

Glycolic acid has been used as a reducing agent in the treatment of high-level waste (Smith et al. 1996). Glycolic and citric acids behave similarly to formic acid. Formic acid supplies two reducing electrons per mole, while glycolic acid provides six electrons per mole. Possible reactions involving glycolic acid with nitrate include the following:

$$
\begin{gathered}
\mathrm{NO}_{3}^{-}+8 \mathrm{HOCH}_{2} \mathrm{COOH} \longleftrightarrow 6 \mathrm{NH}_{3} \uparrow+16 \mathrm{CO}_{2} \uparrow+6 \mathrm{OH}^{-}+4 \mathrm{H}_{2} \mathrm{O} \uparrow \\
\mathrm{NO}_{3}^{-}+5 \mathrm{HOCH}_{2} \mathrm{COOH} \longleftrightarrow 3 \mathrm{~N}_{2} \uparrow+10 \mathrm{CO}_{2} \uparrow+6 \mathrm{OH}^{-}+7 \mathrm{H}_{2} \mathrm{O} \uparrow \\
6 \mathrm{NO}_{3}^{-}+4 \mathrm{HOCH}_{2} \mathrm{COOH} \longleftrightarrow 3 \mathrm{~N}_{2} \mathrm{O} \uparrow+8 \mathrm{CO}_{2} \uparrow+6 \mathrm{OH}^{-}+5 \mathrm{H}_{2} \mathrm{O} \uparrow \\
6 \mathrm{NO}_{3}^{-}+3 \mathrm{HOCH}_{2} \mathrm{COOH} \longleftrightarrow \mathrm{NO} \uparrow+6 \mathrm{CO}_{2} \uparrow+6 \mathrm{OH}^{-}+3 \mathrm{H}_{2} \mathrm{O} \uparrow \\
\mathrm{NO}_{3}^{-}+2 \mathrm{HOCH}_{2} \mathrm{COOH} \longleftrightarrow \mathrm{NO}_{2}^{-}+4 \mathrm{CO}_{2} \uparrow+4 \mathrm{H}_{2} \mathrm{O} \uparrow \\
6 \mathrm{NO}_{3}^{-}+\mathrm{HOCH}_{2} \mathrm{COOH}+\mathrm{H}_{2} \mathrm{O} \longleftrightarrow \mathrm{NO}_{2} \uparrow+2 \mathrm{CO}_{2} \uparrow+6 \mathrm{OH}^{-}
\end{gathered}
$$

Complexing agents, such as citric acid, have been found to be effective as reducing agents in the presence of radiation (Bray and Martin 1962). Similar reactions as those listed above occur with citric acid, although 18 reducing electrons per mole are involved. Table A.1 provides some data with respect to the energy release of organic-nitrate reactions.

Table A.1. Specific Energy of $\mathrm{NaNO}_{3}$ - Organic Reaction (Beitel 1976a)

\begin{tabular}{|c|c|c|c|}
\hline Organic & wt\% $\mathbf{N a N O}_{3}$ & Sp. Energy (cal/g) & TNT Equivalent \\
\hline Carbon & 85 & 940 & 0.85 \\
\hline Carbon & 81 & 756 & 0.69 \\
\hline Carbon & 74 & 550 & 0.5 \\
\hline Carbon & 59 & 435 & 0.39 \\
\hline Carbon & 41 & 307 & 0.28 \\
\hline Carbon & 90 & 173 & 0.16 \\
\hline $\mathrm{C}_{10} \mathrm{H}_{22}$ & 88 & 1000 & 0.91 \\
\hline $\mathrm{C}_{10} \mathrm{H}_{22}$ & 92 & 333 & 0.30 \\
\hline $\mathrm{C}_{10} \mathrm{H}_{22}$ & 70 & 399 & 0.36 \\
\hline Styrene & 86 & 960 & 0.87 \\
\hline
\end{tabular}




\section{A.3 Denitration Catalysts}

Some work has been done using catalysts to improve the rate of denitration. Iron has been shown to catalyze denitration with formic acid, formaldehyde, and sugar (MacDougall et al. 1982). Nitric acid $(6 \mathrm{M}, 500 \mathrm{ml})$, with and without iron, were added to a reaction vessel and heated to $100^{\circ} \mathrm{C}$. The iron content was varied from 0 to $0.2 \mathrm{M} \mathrm{Fe}^{(\mathrm{III})}$. Sucrose $(2.5 \mathrm{M}, 50 \mathrm{ml})$ was added to the reaction vessel at a rate of $10 \mathrm{ml} / \mathrm{min}$. The number of moles of acid reacting with 1 mole of carbon remained constant with increasing iron content, but the reaction rate increased with increasing iron content. At $110^{\circ} \mathrm{C}$, however, the rate of denitration was found to be invariant with respect iron concentration.

Meile and Johnson (1984) examined the effectiveness of copper, zinc, platinum, nickel, rhodium, iron oxide, aluminum oxide, and aluminosilicate to act as catalysts in the denitration process. Nickel and copper were tested in the form of metal turnings, platinum and rhodium as wire, zinc as shot, iron oxide as pellets, aluminum oxide as small spheres, and zeolon as extruded pellets. These forms of catalysts may not be of the most optimal form, but were used in their experiments nonetheless. Denitration was carried out using sodium nitrate and a reductant in a 1:1 ratio. The solution was then evaporated to dryness. Although the results of these catalyst tests were not normalized with respect to catalyst surface area, moisture content, etc., nickel was reported to be the most effective catalytic material.

Brickford et al. (1991) studied denitration and $\mathrm{NO}_{\mathbf{x}}$ evolution in the use of formic acid as a mercuryreducing agent. Under certain conditions, the presence of transition or noble metals resulted in significant formic acid decomposition, with associated $\mathrm{CO}_{2}$ and $\mathrm{H}_{2}$ evolution:

$$
\mathrm{HCOOH} \longleftrightarrow \mathrm{H}_{2} \uparrow+\mathrm{CO}_{2} \uparrow
$$

Saum (1981) demonstrated that the acceleration of denitration in the presence of noble metals is marginal, leading to the production of ammonia through the reaction:

$$
2 \mathrm{NO} \uparrow+5 \mathrm{H}_{2} \uparrow \longleftrightarrow 2 \mathrm{NH}_{3} \uparrow+2 \mathrm{H}_{2} \mathrm{O} \uparrow
$$

Sugiyama and Takahashi (1967) studied the effect of various metal oxides on $\mathrm{NaNO}_{3}$ and $\mathrm{NaNO}_{2}$ decomposition. They reported significantly altered gas ratios and lower decomposition temperatures in the presence of small amounts of $\mathrm{V}_{2} \mathrm{O}_{5}, \mathrm{NiO}, \mathrm{ZnO}, \mathrm{CoO}$, or $\mathrm{MgO}$.

\section{A.4 Thermochemical Denitration}

In the thermochemical denitration experiments performed by Ray and Ogg (1956), a mixture of various amounts of potassium nitrite and nitrate, chromic oxide, and ferric oxide was heated to slightly above $300^{\circ} \mathrm{C}$. As the potassium nitrate level was reduced, the gas collected contained increasing amounts of nitrogen and nitrous oxide. Material containing no potassium nitrite reacted to give $7 \%$ nitrogen, $15 \%$ nitrous oxide, and the balance nitric oxide. Kozlowski and Bartholomew (1968) studied the reactions of $\mathrm{NaCOOH}$ and $\mathrm{NaC}_{2} \mathrm{H}_{3} \mathrm{O}_{2}$ with $\mathrm{NaNO}_{2}$ and $\mathrm{NaNO}_{3}$ by dropping the $\mathrm{NaCOOH}$ and $\mathrm{NaC}_{2} \mathrm{H}_{3} \mathrm{O}_{2}$ into the 
sodium nitrate or sodium nitrite $(50 \mathrm{mg})$ melt held at $330^{\circ} \mathrm{C}$ using an argon purge gas. Nitrous oxide was determined to be one of the reaction products.

Hoshino et al. (1981) studied the effects of several oxides on the decomposition of sodium nitrate using thermal analysis, gas analysis, and chemical analysis. Less than $80 \mathrm{mg}$ of sample were heated in a reaction vessel to $900^{\circ} \mathrm{C}$ at 5 or $20^{\circ} \mathrm{C} / \mathrm{min}$. Argon $(50 \mathrm{ml} / \mathrm{min})$ was used as the carrier gas. In the presence of $\mathrm{SiO}_{2}, \mathrm{TiO}_{2}$, and $\mathrm{ZrO}_{2}$, no $\mathrm{N}_{2}$ formed, and the reaction peak was narrow, indicating a relatively fast reaction. Nitrogen production increased, and the decomposition occurred more slowly in the presence of $\mathrm{Al}_{2} \mathrm{O}_{3}$ and $\mathrm{MgO}$. For the $\mathrm{NaNO}_{3}$ decomposition without the presence of oxides, the reaction is exothermic, and $\mathrm{N}_{2}$ is also produced. In the presence of $\mathrm{SiO}_{2}$ (at $700^{\circ} \mathrm{C}$ ), $\mathrm{TiO}_{2}$ (at $640^{\circ} \mathrm{C}$ ), and $\mathrm{ZrO}_{2}$ (at $690^{\circ} \mathrm{C}$ ), the reactions are endothermic.

Abe et al. (1983) examined sodium nitrite destruction in the presence of silica using TGA-differential thermal analysis (DTA) with a gas chromatograph (GC). A mixture of silica and sodium nitrite (6.9 to $66.9 \mathrm{mg}$ ) containing 0.1 mmoles or 0.2 mmoles of sodium nitrite was placed in a platinum vessel using Ar or $\mathrm{O}_{2}$ as the purge gas $(50 \mathrm{ml} / \mathrm{min})$. The samples were heated to $800^{\circ} \mathrm{C}$ at 5 to $20^{\circ} \mathrm{C} / \mathrm{min}$ after holding at $250^{\circ} \mathrm{C}$ for 1 hour to remove the adsorbed water. Sodium nitrite decomposed above $400^{\circ} \mathrm{C}$, generating only $\mathrm{NO}$, and above $500^{\circ} \mathrm{C}$, generating $\mathrm{NO}, \mathrm{O}_{2}$, sodium nitrate, sodium metasilicate, and disodium disilicate. Results indicated that sodium peroxide forms and is stable in an argon atmosphere at temperatures below $530^{\circ} \mathrm{C}$ :

$$
2 \mathrm{NaNO}_{2} \longleftrightarrow \mathrm{Na}_{2} \mathrm{O}_{2}+2 \mathrm{NO} \uparrow
$$

Silicates and sodium nitrate formed between 530 and $600^{\circ} \mathrm{C}$. Above $600^{\circ} \mathrm{C}$, the reaction is identical with that of sodium nitrate with silica because the main species in the melt is sodium nitrate. As the proportion of silica was increased, decomposition temperature decreased, and the activation energy increased.

Meile and Johnson (1984) examined two types of thermal denitration processes, one involving a high-temperature fluid wall reactor (HTFWR) and another involving a carbon-nitrate reaction in a molten salt reactor. In the HTFWR, at temperatures of $2200^{\circ} \mathrm{C}$ and in the presence of carbon black, $96 \%$ of the original nitrate was destroyed, and no $\mathrm{NO}_{2}$ was detected in the products. In the absence of the carbon black, only $80 \%$ of the nitrate was decomposed. In the molten salt reactor at $1000^{\circ} \mathrm{C}$, a $99 \%$ reduction of nitrate occurred, generating low but detectable concentrations of $\mathrm{NO}_{\mathrm{x}}(100$ to $500 \mathrm{ppm})$.

Thermochemical denitration has been examined by Cox et al. (1992). Cox reported thermochemical nitrate destruction in a high temperature $\left(350^{\circ} \mathrm{C}\right)$ batch reactor under basic conditions using glucose as the reducing agent. It was determined that glucose destroyed $48 \%$ of the nitrate. $\mathrm{N}_{2} \mathrm{O}$ and $\mathrm{NH}_{3}$ were not detected in the offgas. 


\section{A.5 Implications to Other DOE Wastes}

The technology described in this report can be applied to many high nitrate waste streams within the DOE complex. Described below are specific examples from Hanford and LANL. Hanford Site LLW is characterized by high nitrate and nitrite concentrations. Nitrogen-containing offgas products will thus naturally be of concern during $\mathrm{LLW}$ vitrification operations. For example, $\mathrm{NO}_{\mathrm{x}}$ is environmentally damaging and can affect the volatility of certain radionuclides via gas-phase entrainment during vitrification; $\mathrm{NH}_{3}$ in the offgas can potentially lead to the development of $\mathrm{NH}_{4} \mathrm{NO}_{3}$ deposits in the offgas system, which constitutes a potential explosion hazard.

Thermal denitration destroys sodium nitrate and sodium nitrite using temperatures in excess of $500^{\circ} \mathrm{C}$. The reaction paths and the relative concentrations of offgas products as well as the percent destruction of the sodium compounds are dependent on the test and operating conditions. For example, the presence of oxides as well as the material of the reaction vessel can change the reaction paths. Generally, decomposition begins above $400^{\circ} \mathrm{C}$, and the offgas products are $\mathrm{NO}, \mathrm{N}_{2}$, and $\mathrm{O}_{2}$, and sometimes $\mathrm{N}_{2} \mathrm{O}$. Sodium nitrate and nitrite have also been shown to be volatile. Denitration can be carried out thermally, but temperatures over $800^{\circ} \mathrm{C}$ are required for the reaction to approach completion. Generally, $80 \%$ to $95 \%$ of the nitrate is destroyed without a reductant.

The denitration temperature can be lowered, and the reaction pathways can be altered through the use of thermochemical denitration. Through the action of added reductants, for example, the distribution of nitrogen-containing offgas products can be altered to contain a greater abundance of reduced (and environmentally benign) products such as $\mathrm{N}_{2}$.

\section{A.6 Glycine-Nitrate Process}

Radiochemical wastes from processing operations at various government sites across the nation are currently being treated and immobilized by calcination. Many streams derived from low activity waste (LAW) contain large amounts of sodium nitrate, which requires substantial diluent, is difficult to calcine and generates substantial nitrogen oxide releases. Preconditioning (i.e., evaporation and subsequent denitration) has been proposed to substantially reduce emissions and produce a stable grout matrix using less diluent.

Two methods have been proposed for denitration of LAW after it is concentrated by evaporation. These two methods are 1) direct high temperature calcination in a fluidized bed, and 2) thermochemical denitration using sugar as a reductant. This engineering brief discusses the feasibility of adapting the existing glycine nitrate process for synthesis of ceramics towards denitration of sodium-bearing waste (SBW). The reactions are similar in nature, releasing nearly all the nitrate as nitrogen gas rather than NOx. While the reactions are vigorous, researchers indicate that they are more stable than sugar-nitrate reactions proposed. The glycine nitrate process has been safely used commercially at powder production rates exceeding 1 kilogram per hour and merits further study for denitration applications. 


\section{A.6.1 Process Chemistry}

The glycine nitrate process was originally developed by researchers at the Pacific Northwest National Laboratory (PNNL) in the early 90's as a novel process for synthesis of specialty ceramic powders. These powders are in high demand for production of solid oxide fuel cells, ceramic engine parts, and many other sophisticated, valuable products. In the Battelle process, an aqueous solution of the appropriate metal nitrates and the amino acid glycine is intimately mixed, heated to drive off the water, and reacted at temperatures between 200 and $1400^{\circ} \mathrm{C}$. The resulting metal oxide powders have high surface area and are prized for their chemical reactivity and their ability to be readily sintered to high density shapes.

The proposed glycine denitration process (G-DENIT) reacts waste nitrate salts (sodium and potassium primarily) instead of normal ceramic precursors such as strontium, lanthanum, or chromium nitrates. These waste nitrate salts may be constituents of a variety of waste streams, including both $\mathrm{HLW}$ and LLW, and possibly mixed wastes.

Reaction of waste nitrate salts with sugar has been researched extensively at many US Department of Energy sites, including the Idaho Chemical Processing Plant (ICPP) and the Pacific Northwest Laboratory (PNNL) as a potential way to reduce NOx emissions from calcination. Many reductants such as formic acid, activated carbon, corn starch, glycolic acid, oxalic acid, and others have been employed in the literature. In most cases, organic-nitrate reactions can be described as vigorous exothermic thermochemical reactions and thus have significant safety questions which must be answered prior to use.

High sodium waste streams (SBW) can be handled by the addition of small amounts of ANN as with existing fluid bed calcination processes. ANN dilutes and slows the sodium nitrate reactions, making the overall reactions more manageable. If the waste products are to be grouted, it is probable that the exact composition desired in the grout can be formulated directly. It may be possible to reduce ANN addition over that in the high temperature calcine flowsheet. Without fluid bed processing, the concerns of agglomeration are reduced.

The stoichiometry for the Glycine Nitrate process is actually quite similar to that for the sugar denitration reactions. The reaction is as follows:

$$
10 \mathrm{H}_{2} \mathrm{~N}-\mathrm{CH}_{2}-\mathrm{COOH}+18 \mathrm{NaNO}_{3} \longleftrightarrow 9 \mathrm{Na}_{2} \mathrm{O}+14 \mathrm{~N}_{2} \uparrow+25 \mathrm{H}_{2} \mathrm{O} \uparrow+20 \mathrm{CO}_{2} \uparrow
$$

Once an aqueous solution of glycine and nitrate salt is evaporated to near dryness, a vigorous exothermic reaction ensues, throwing the ash away from the reaction zone due to the high level of gas production. Heats of reaction are substantial $(\sim 230 \mathrm{kcal} / \mathrm{mol})$; however, Chick et al. (1990) observed that glycine processes are steadier and more easily controlled than sugar-based reactions. At near stoichiometric fractions of glycine and nitrate, very little nitrogen ends up as oxides. 


\section{A.6.2 Process Description}

The current glycine nitrate process consists of a metering and mixing step where the appropriate volumes of reactants are mixed in an aqueous solution, a drying step where the mixture is pre-heated and water is removed, a reaction step where the nitrate and glycine undergo a highly exothermic reaction, and a particulate separation step(s) where the offgas is scrubbed of reaction products. A $1 \mathrm{~kg} / \mathrm{hr}$ production unit was built in the early 1990s and has been operational at Seattle Specialty Ceramics (SSC) in Bothell, WA under a CRADA since that time.

In the flowsheet design outlined below, a majority ( $>50 \%)$ of the nitrate in the incoming SBW can be removed as nitric acid by vacuum evaporation. The acid is condensed and can be reused elsewhere in DOE complex. The concentrated SBW stream is then statically mixed with glycine in the appropriate stoichiometry immediately prior to introduction into the rotary kiln reactor.

The commercial production unit operates on a rotary kiln-type concept. The solution is injected into a rotary tube furnace, where it forms a thin slurry coating on the wall, evaporates to dryness, and reacts. The reaction products fall off the wall of the tube furnace and are entrained in the sweep gases within the tube. The particulate is cyclonically separated and scrubbed after exiting the tube furnace. The denitration flowsheet design would employ two sequential cyclones followed by a wet scrubber/demister and a final HEPA. All particulate and scrubber blowdown can be mixed with grout-formers and poured into final waste form.

\section{A.6.3 Safety Issues and Operational History}

The intimate mixing of an organic fuel (either sugar or glycine) with an oxidizer (nitrates) presents several potential safety problems. Black powder-type reactions have been studied since the Chinese invented gunpowder. Other possible sugar-nitrate interactions with regard to calcined SBW have been thoroughly described (Marshall and Green 1996). When confined in sufficient quantities, such mixtures can be quite energetic. However, if the actual reaction inventory can be minimized and the materials are not tightly confined, a controlled reaction can be accomplished as evidenced by the operating track record of the Glycine Nitrate Process. Such is the reason that the streams are proposed to be statically mixed just prior to reaction and a rotary tube furnace was chosen as the design for the pilot unit. This causes only a few tens of grams to be in the reaction zone at any one time. Any temperature changes or excursions can be closely monitored. Water can be substituted for SBW and glycine if operations stray outside of limits.

The production unit began testing at PNNL in late 1992 and was operated at SSC from early 1993 through 1997. Nearly 1000 hours of production time have been logged, producing nearly $1000 \mathrm{~kg}$ of highly valuable specialty ceramics. Operators have described the units operation as "smooth" for a pilot unit. As the material is sprayed on the wall of the furnace, it dries and reacts. The reaction front moves slightly within the furnace tube, depending on the temperatures. 


\section{A.6.4 Patents and Awards}

The Glycine Nitrate Process has been awarded several patents (Aksay et al. 5,061,682; Maupin et al. $5,705,132)$ and received an "R\&D100" award for being one of the top 100 new technologies of 1992 as determined by Research \& Development Magazine. In addition, the process also received a Federal Laboratory Consortium (FLC) award for Excellence in Technology Transfer in 1993.

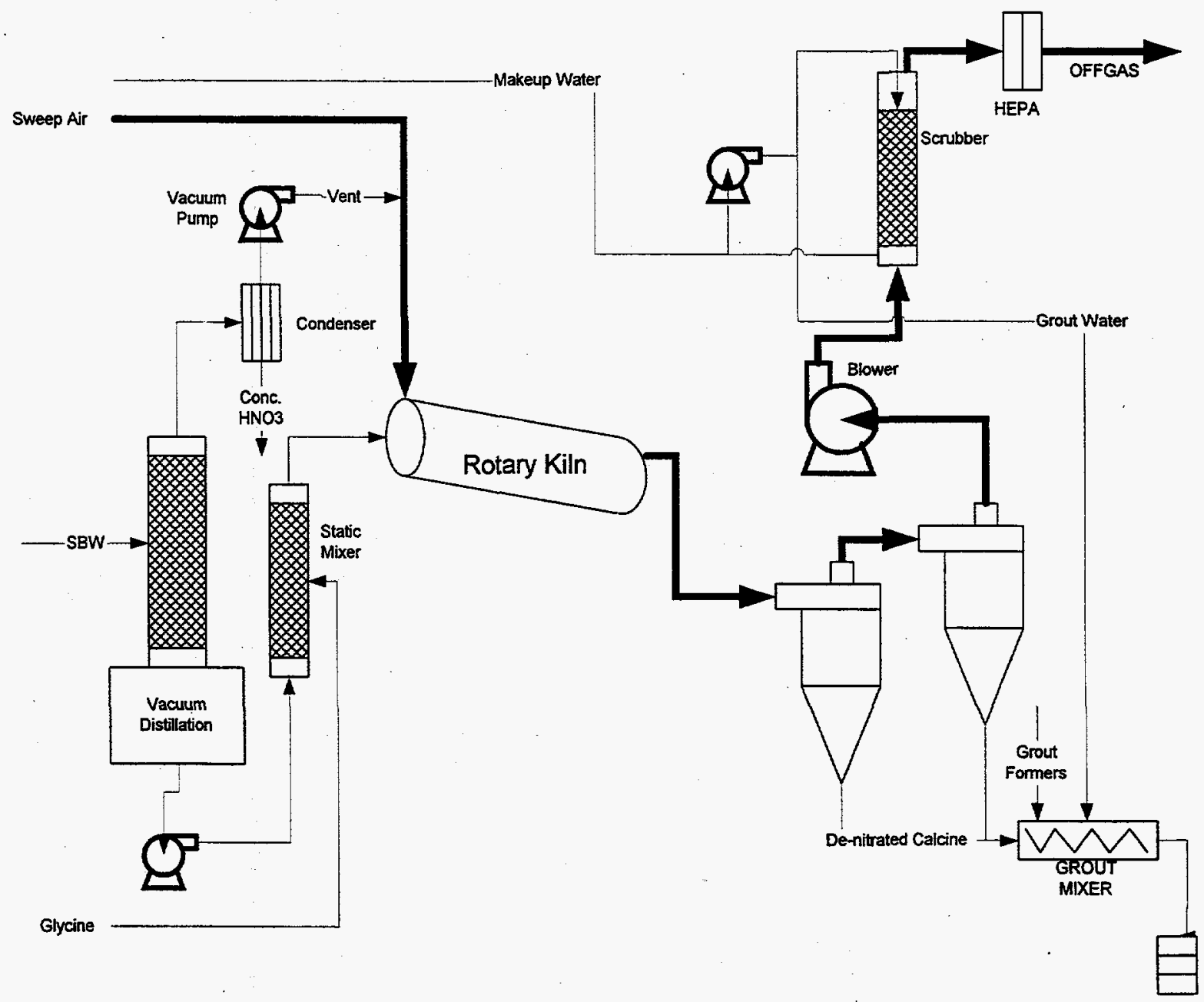

Figure A.1. Glycine Denitration Process 


\section{Appendix B}

Annotated Literature Review 


\section{Appendix B}

\section{Annotated Literature Review}

Beitel, G.A. 1976. Chemical Stability of Salt Cake in the Presence of Organic Materials, ARH-LD-119, Atlantic Richfield Hanford Company, Richland, Washington.

* Reviews instances nitrate-organic reaction incidents. Gives an concise review of the development and characteristics of "black powder". Black powder is insensitive to minor variations in composition and the black powder industry never did establish compositional limits. The properties of fuse powder are a slow, uniform burn rate. This is achieved by adding inert or fire retardant materials to standard black powder. The ignition temperature of $\mathrm{KNO}_{3}+\mathrm{Charcoal}$ is about $470^{\circ} \mathrm{C}$ and is reduced to about $300^{\circ} \mathrm{C}$ with the addition of sulfur. Black powder does not detonate with reaction propagation at less than $400 \mathrm{~cm} / \mathrm{sec}$. Nitrated organics are those that exhibit explosion risks. When these are made unexpectedly or by accident they generally explode. Work with a simulated saltcake containing $33 \mathrm{wt} \% \mathrm{NaNO}_{3}$ and $14 \mathrm{wt} \%$ $\mathrm{NaNO}_{2}$ or pure $\mathrm{NaNO}_{3}$ mixed with a polyglot mixture of rubbers, resins, and solvents is reported. First a flame temperature calculation is described where the heat of reaction is used to heat the reaction products. For example:

$$
4 \mathrm{NaNO}_{3}+5 \mathrm{C} \longleftrightarrow 2 \mathrm{Na}_{2} \mathrm{CO}_{3}+3 \mathrm{CO}_{2} \uparrow+2 \mathrm{~N}_{2} \uparrow+375.8 \mathrm{kcal}
$$

produces enough energy to heat unreacted material to the ignition temperature. Using this kind of calculation the limits of combustion limits are $7 \mathrm{wt} \%$ to $57 \mathrm{wt} \%$ carbon in dry mixtures. Some explosion scenarios are discussed. Calculated energy releases are shown in the table below.

\begin{tabular}{|l|l|l|l|}
\hline \multicolumn{4}{|c|}{ Specific Energy of NaNO - Organic Reaction } \\
\hline Organic & \multicolumn{1}{|c|}{ Wt\% NaNO $_{3}$} & Sp. Energy (cal/g) & TNT Equivalent \\
\hline Carbon & 85 & 940 & 0.85 \\
\hline Carbon & 81 & 756 & 0.69 \\
\hline Carbon & 74 & 550 & 0.5 \\
\hline Carbon & 59 & 435 & 0.39 \\
\hline Carbon & 41 & 307 & 0.28 \\
\hline Carbon & 90 & 173 & 0.16 \\
\hline $\mathrm{C}_{10} \mathrm{H}_{22}$ & 88 (stoichiometric) & 1000 & 0.91 \\
\hline $\mathrm{C}_{10} \mathrm{H}_{22}$ & 92 & 333 & 0.30 \\
\hline $\mathrm{C}_{10} \mathrm{H}_{22}$ & 70 & 399 & 0.36 \\
\hline Styrene & 86 & 960 & 0.87 \\
\hline
\end{tabular}

B.1 
Note that a increase in nitrate content of $4 \mathrm{wt} \%$ over the stoichiometric mix reduces the available energy by a factor of three. Radiation was found to have little effect on the nitrate-organic mixes. $\mathrm{NaNO}_{3}$ has about the same stability to radiation as many organics, $0.6 \%$ was decomposed after exposure to $1.4 \times 10^{8}$ rads (electron beam). Comment on nitrate - metal powder reactions: care needed, reactions rapid and highly exothermic.

Beitel, G. A. 1976. Sodium Nitrate Combustion Limit Tests, ARH-LD-123, Atlantic Richfield Hanford Company, Richland, Washington.

* Tests were performed with one-gram samples of nitrate-organic mixes that ranged from fuel rich to fuel poor. Mixtures at either extreme would not react. Test consisted of one-gram masses packed into aluminum foil cylinders with a black powder igniter mix at one end that was started with a hot wire. A visualtime qualitative scale was set up as an evaluation basis to describe the combustion. Combinations included sodium nitrate and charcoal $(\sim 85 \mathrm{wt} \% \mathrm{C})$, charcoal-moisture, charcoal-moisture-temp., paraffin, resin, or sugar. A salt cake (90-95\% nitrate) charcoal mixture was also used. Below $380^{\circ} \mathrm{C} \mathrm{NaNO}{ }_{3}$ was stable and would not support combustion. With more than $20 \%$ moisture no mixture supported combustion. Mixtures with more than $95 \%$ or less than $35 \% \mathrm{NaNO}_{3}$ did not react with enough energy to support combustion. Only the hottest combustion events melted the aluminum foil $\left(657^{\circ} \mathrm{C}\right)$. With charcoal, mixtures with 65 to $85 \% \mathrm{NaNO}_{3}$ burned rapidly. At the oxidant-rich limit, the mixture is extinguished by melting nitrate, which melts below the ignition temperature. Mixtures with organic that volatilize at low temperature did not react because the organic was gone before the ignition temperature was reached.

Resin and nitrate mixtures essentially would not burn. In the discussion section, the point is made that it is the decomposition of $\mathrm{NaNO}_{3}$ beginning at about $380^{\circ} \mathrm{C}$ that initiates the combustion process by releasing oxidizing species. Charcoal reacts at $380-400^{\circ} \mathrm{C}$ because it releases organic compounds at that temperature which raises the temperature in the region to the combustion temperature for carbon $\left(550^{\circ} \mathrm{C}\right)$.

Beitel, G. A. 1977. Exothermic Potential of Sodium Nitrate Salt Cake, ARH-LD-163, Atlantic Richfield Hanford Company, Richland, Washington.

* The following conclusions were reached:

1. Salt Cake $\left(95 \% \mathrm{NaNO}_{3}\right)$ - organic mixtures are stable below $250^{\circ} \mathrm{C}$.

2. Salt Cake $\left(95 \% \mathrm{NaNO}_{3}\right)$ - organic mixtures will react explosively at temperatures above $400^{\circ} \mathrm{C}$ if the organics are still liquid or solid.

3. A volatile hydrocarbon will burn with atmospheric oxygen and not with sodium nitrate if the nitrate temperature is below $400^{\circ} \mathrm{C}$. 
Bibler, N. E., J. E. Hoisington, and E. W. Holtzscheiter. March 1981. Technical Data Summary Decomposition of Oxalic Acid by the Manganese Catalyzed Nitric Acid Reaction. DPSTD-80-36, Savannah River Laboratory, Aiken, South Carolina.

* Oxalic acid is oxidized by nitric acid by one of the following reactions which occur only in the presence of a small amount of $\mathrm{Mn}^{+2}$ :

$$
\begin{aligned}
& 4 \mathrm{H}_{2} \mathrm{C}_{2} \mathrm{O}_{4}+2 \mathrm{HNO}_{3} \longleftrightarrow 8 \mathrm{CO}_{2} \uparrow+\mathrm{N}_{2} \mathrm{O} \uparrow+5 \mathrm{H}_{2} \mathrm{O} \uparrow \\
& 3 \mathrm{H}_{2} \mathrm{C}_{2} \mathrm{O}_{4}+2 \mathrm{HNO}_{3} \longleftrightarrow 6 \mathrm{CO}_{2} \uparrow+2 \mathrm{NO} \uparrow+4 \mathrm{H}_{2} \mathrm{O} \uparrow \\
& \mathrm{H}_{2} \mathrm{C}_{2} \mathrm{O}_{4}+2 \mathrm{HNO}_{3} \longleftrightarrow 2 \mathrm{CO}_{2} \uparrow+2 \mathrm{NO}_{2} \uparrow+2 \mathrm{H}_{2} \mathrm{O} \uparrow
\end{aligned}
$$

Reaction (1) does not take place in the presence of $\mathrm{Fe}^{+3}$ and the $\mathrm{HNO}_{3}$ concentration is less than $1 \mathrm{M}$.

The minimum $\mathrm{HNO}_{3}$ concentration for the reaction to go is given as:

$$
\left[\mathrm{HNO}_{3}\right]_{\min }=\mathrm{R}\left[\mathrm{C}_{2} \mathrm{O}_{4}{ }^{=}\right]-\left[\mathrm{H}^{+}\right]_{\mathrm{ox}} \text { where } \mathrm{R}={ }_{\Delta} \mathrm{H}^{+} / \Delta \mathrm{C}_{2} \mathrm{O}_{4}{ }^{=}
$$

Reaction kinetics are first order: $\left(\mathrm{H}_{2} \mathrm{C}_{2} \mathrm{O}_{4}\right)_{\mathrm{t}} /\left(\mathrm{H}_{2} \mathrm{C}_{2} \mathrm{O}_{4}\right)_{\mathrm{o}}=\mathrm{e}^{-\mathrm{kt}}$. Results for various laboratory tests are reported such as the amount of $\mathrm{H}_{2} \mathrm{C}_{2} \mathrm{O}_{4}$ reacted as a function of time and the effect of $\mathrm{Mn}^{2+}$ on the value of k.

Eaton, W. C. November 1995. U.S. Bureau of Mines, Phase I Hanford Low-Level Waste Melter Tests: Final Report. WHC-SD-WM-VI-030, Rev. 0, Westinghouse Hanford Company, Richland, Washington.

* Describes the results of a pilot scale test in which nitrate/nitrite was destroyed in a melter feed batch using a sugar-carbon mixture (about equal weights of each). The feed contained $25 \mathrm{wt} \%$ waste that was $\sim 5 \mathrm{wt} \%$ nitrate and $\sim 1 \mathrm{wt} \%$ nitrite. Measurements indicated $65-80 \%$ of the nitrogen was released as $\mathrm{N}_{2}$ gas.

Oden, Laurence L. 1995. Phase I Demonstration of 3-Phase Electric Arc Melting Furnace Technology for Vitrifying High-Sodium Content Low-Level Radioactive Liquid Wastes, Rev. 1. Test Plan, U.S. Bureau of Mines, Department of the Interior, Albany Research Center, Albany, Oregon.

* A process for making pellets including the reductant and capable of absorbing more than $25 \mathrm{wt} \%$ liquid waste is described. Sucrose, corn starch, urea, and activated carbon were found to be effective reductants, but a combination of sugar and carbon was found to be the best in terms of initiation temperature. In terms of residual carbon and nitrogen, a $75 \%$ of stoichiometric reductant loading was found to be the most effective ( $25 \%$ sugar and $50 \%$ carbon). The waste solution was $13.53 \mathrm{wt} \%$ nitrate ion and $5.28 \mathrm{wt} \%$ nitrite ion. Note: the presence of nitrite may be the reason for the lower ignition temperature reported for these mixtures of $\sim 260^{\circ} \mathrm{C}$ ). 
ORNL News Release, Aluminum powder reacts with sodium nitrate in solution at $50^{\circ} \mathrm{C}$ to produce alumina and ammonia. (Not dated)

Sills, J. A. February 1995. Evaluation of Hanford High Level Waste Vitrification Chemistry for an NCAW Simulant--Fiscal Year 1994: Potential Exothermic Reactions in the Presence of Formic Acid, Glycolic Acid, and Oxalic Acid. PVTD-C95-02.02L, Pacific Northwest National Laboratory, Richland, Washington.

* HWVP simulants were treated with formic, glycolic, and oxalic acids to produce acid waste slurries. The dried treated slurries and supernates, and sodium salt-sodium nitrate mixes were evaluated for exothermic output using differential scanning calorimetry. The feed simulants included 0.118 moles of nitrate and 0.435 moles of nitrite per liter of simulant. However, during acidification of the simulant the nitrite is destroyed by disproportionation of nitrous acid forming an additional 0.145 moles of nitrate as one of the reaction products, so the acid treated simulant may end up with as much as 0.263 moles of nitrate per liter of simulant if nitrate is not being reduced to nitrite also. Formic acid treated supernate evolved $1100 \mathrm{~J} / \mathrm{g}$ of dried supernate. Exotherm onset temperatures for slurries treated with formic, glycolic, and oxalic acids were $\sim 133^{\circ} \mathrm{C}, \sim 166^{\circ} \mathrm{C}$, and $\sim 209^{\circ} \mathrm{C}$, respectively. For the supernates from the respective slurries, the corresponding onset temperatures were $\sim 192^{\circ} \mathrm{C}, \sim 158^{\circ} \mathrm{C}$, and $\sim 203^{\circ} \mathrm{C}$.

Scheele, R. D., J. L. Sobolisk, L. L. Barger, R. L. Sell and D. J. Tomich. “Organic Tank Safety Program Energetics Task." May 12, 1994, Hanford Site, Washington.

*In this presentation, combination plots of the TGA, DSC, and DTA results for the sodium organic saltsodium nitrate mixes are shown. In addition, a table of onset temperatures based on the various calorimetric measurements is presented, showing again that the ARC measurements give the lowest values. The acetate showed a significantly higher initiation temperature than the other compounds studied. See comments on monthly above.

Fisher, Fred D. August 1990. The Kyshtym Explosion and Explosion Hazards with Nitrate-Nitrite Bearing Wastes with Acetates and Other Organic Salts. WHC-SD-CP-LB-033, Westinghouse Hanford Company, Richland, Washington.

*The Kyshtym Explosion was apparently the result of waste tanks containing sodium acetate and nitrates explosively reacting when a cooling system failed, permitting the tanks to overheat. This is consistent with other data that indicate nitrate salts containing more than $10 \%$ of Sodium Salts of Carboxylic Acids may explode (e.g., Koslowski and Bartholomew 1968 [Appendix D]). These mixtures apparently are not shock sensitive, only temperature sensitive. A temperature of $260^{\circ} \mathrm{C}$ minimum was indicated for nitritecontaining systems, and over $300^{\circ} \mathrm{C}$ was indicated for nitrate systems. 
Sokolov, N. M. September 1954. "Reaction of Sodium Salts of Carboxylic Acids in Melts". Jour. of General Chemistry of the USSR, Vol. XXIV, No. 9, pp. 1567-1576. (Consultants Bureau translation.)

*This paper is really about the phase relationships in sodium carboxylate salt pairs. These salts have two melting points: one in which a liquid crystal is formed and another where the liquid is truly amorphous. Compounds such as sodium butyrate $\left(210^{\circ} \mathrm{C}\right.$ and $\left.310^{\circ} \mathrm{C}\right)$ and sodium isovalerate $\left(168^{\circ} \mathrm{C}\right.$ and $\left.260^{\circ} \mathrm{C}\right)$ were studied.

Oza, T. M. and B. R. Walawalkar. January 1945. "The Thermal Decomposition of Sodium and Potassium Nitrites. Part II. Action of Nitric Oxide, Oxygen and Nitrogen Peroxide on Fused Nitrites". Jour. Indian Chemical Soc., Vol. XXII, No. 1, pp. 243-249.

*These authors conclude that decomposition products at temperatures of $330^{\circ} \mathrm{C}$ and $380^{\circ} \mathrm{C}$ for sodium nitrite and $410^{\circ} \mathrm{C}$ and $460^{\circ} \mathrm{C}$ for potassium nitrite indicated the following reactions:

1) Primary stage: $4 \mathrm{MNO}_{2} \longleftrightarrow 2 \mathrm{M}_{2} \mathrm{O}+2 \mathrm{NO} \uparrow+2 \mathrm{NO}_{2} \uparrow$

2) Product reactions: $\mathrm{M}_{2} \mathrm{O}+2 \mathrm{NO}_{2} \uparrow \longleftrightarrow \mathrm{MNO}_{2}+\mathrm{MNO}_{3}$ and

$$
\mathrm{MNO}_{2}+\mathrm{NO}_{2} \uparrow \longleftrightarrow \mathrm{MNO}_{3}+\mathrm{NO} \uparrow
$$

3) Product reactions (NO): $2 \mathrm{MNO}_{2}+2 \mathrm{NO} \longleftrightarrow 2 \mathrm{MNO}_{3}+\mathrm{N}_{2} \uparrow$

Kozlowski, T. R. and R. F. Bartholomew. November 1968. "Reactions between Sodium Carboxylic Salts and Molten Sodium Nitrate and Sodium Nitrite". Inorganic Chemistry, Vol. 7, No. 11, pp. 2247-2254.

*The authors found that rapid reaction occurred between $\mathrm{NaCOOH}$ or $\mathrm{NaC}_{2} \mathrm{H}_{3} \mathrm{O}_{2}$ and $\mathrm{NaNO}_{3}$ at around $320^{\circ} \mathrm{C}$. If the carboxylic acid concentration was too high $[>10 \%]$, there was an explosion hazard. The reaction products identified indicated the following reactions:

$$
\begin{aligned}
& \mathrm{NaCOOH}+\mathrm{NaNO}_{3} \longleftrightarrow \mathrm{NaNO}_{2}+\mathrm{Na}_{2} \mathrm{CO}_{3}+\mathrm{H}_{2} \mathrm{O} \uparrow+\mathrm{CO}_{2} \uparrow \\
& \mathrm{NaCOOH}+\mathrm{NaNO}_{2} \longleftrightarrow \mathrm{Na}_{2} \mathrm{CO}_{3}+\mathrm{N}_{2} \mathrm{O} \uparrow+\mathrm{H}_{2} \mathrm{O} \uparrow \\
& \mathrm{NaC}_{2} \mathrm{H}_{3} \mathrm{O}_{2}+4 \mathrm{NaNO}_{3} \longleftrightarrow \mathrm{Na}_{2} \mathrm{CO}_{3}+/ \mathrm{H}_{2} \mathrm{O} \uparrow+4 \mathrm{NaNO}_{2} \\
& \mathrm{NaC}_{2} \mathrm{H}_{3} \mathrm{O}_{2}+3 \mathrm{NaNO}_{2} \longleftrightarrow 2 \mathrm{Na}_{2} \mathrm{CO}_{3}+/ \mathrm{H}_{2} \mathrm{O} \uparrow+\mathrm{N}_{2} \mathrm{O} \uparrow+\mathrm{N}_{2} \uparrow
\end{aligned}
$$


Denitration of Radioactive Liquid Wastes. 1986. Eds. L. Cecille and S. Halaszovich. Radioactive Waste Management Series. Graham \& Trotman, Norwell, Massachusetts.

Merz, E. R. Overview on the Application of Denitration in the Nuclear Field.

* "The main incentive of chemical denitration is reducing the acid content and in turn the salt load of the wastes formed by the neutralization of the acid with caustic soda". The article reviews the benefits of nitric acid in a variety of processes necessary to the nuclear industry. It then discusses how's and why's of denitrification. Nitric acid distillation is briefly described. Lowering nitrate content of melter feeds lowers the volatility of ruthenium, for instance. Organics such as HCHO and sugar are discussed. After free nitrate is removed, additional nitrate can be removed by hydrolysis by treating with formic acid to destroy additional nitrate.

Cecille, L. and M. Kelm. Chemical Reactions Involved in the Denitration Process with HCOOH and HCHO.

* Included in review above.

Gompper, K. Alternative Organic Reductants for Denitration.

* Basically reviews L. Bray's work.

Klonk. H. and M. Stehle. Economic Aspects of Denitration in the Management of Reprocessing Concentrate.

* Basic discussion of reasons to denitrify in several situations and what kind of questions need to be answered.

\section{Schulenberg, T. Safety Aspects about Denitrification.}

* Discusses denitrification with $\mathrm{HCOOH}$. Looks at the conditions for a system for denitrifying $200 \mathrm{~L}$ of nitric acid. Conditions for potential explosions are described. Conditions for oscillatory reaction rates in the presence of noble metal catalysts and their potential for producing unsafe conditions are difficult to predict.

Halaszovich, S. S. Dix, and R. Harms. Denitration of Reprocessing Concentrates by Means of HCHO.

* Describes a denitration process which generates principally NO. Reaction temperatures are in the range of $80-100^{\circ} \mathrm{C}$. Shows offgas results for particular flowsheet conditions. Cautions against running the reaction to produce $\mathrm{N}_{2} \mathrm{O}$ because of the risk of generating flammable gas mixtures containing methylnitrite. 
Kelm, M., B. Oser, and S. Drobnik. Denitration of Reprocessing Concentrate by Means of HCOOH.

* Describes a denitration process which generates $\mathrm{N}_{2} \mathrm{O}$ and $\mathrm{CO}_{2}$. To do this, the waste is added to the formic acid already in the reaction vessel and heated to boiling under refluxing conditions. Depending on the concentration of the nitric acid, the waste was added over a period of 1.5 to 4 hours. After an induction period of a few seconds, the reaction proceeded calmly. The principal reaction is believed to be:

$$
2 \mathrm{HNO}_{3}+4 \mathrm{HCOOH} \longleftrightarrow \mathrm{N}_{2} \mathrm{O} \uparrow+4 \mathrm{CO}_{2} \uparrow+5 \mathrm{H}_{2} \mathrm{O} \uparrow
$$

As the reaction depletes the $\mathrm{HCOOH}, \mathrm{NO}$ production builds up. Also some $\mathrm{N}_{2}$ is produced during the processing. These reaction are:

$$
\begin{aligned}
& 2 \mathrm{HNO}_{3}+3 \mathrm{HCOOH} \longleftrightarrow 2 \mathrm{NO} \uparrow+3 \mathrm{CO}_{2} \uparrow+4 \mathrm{H}_{2} \mathrm{O} \uparrow \\
& 2 \mathrm{HNO}_{3}+5 \mathrm{HCOOH} \longleftrightarrow \mathrm{N}_{2} \uparrow+5 \mathrm{CO}_{2} \uparrow+6 \mathrm{H}_{2} \mathrm{O} \uparrow
\end{aligned}
$$

Denitration efficiencies of $81 \%$ to $99 \%$ were achieved. Nitrogen plus nitrous oxide made up $60 \%$ to $85 \%$ of the nitrogen species released. Hydrogen peroxide was used to destroy the remaining $\mathrm{HCOOH}$ to complete the process. The potential explosion hazard is from volatilized $\mathrm{HCOOH}$ mixed with air, but disappears when the concentration of $\mathrm{HCOOH}$ falls below $79 \%$ in the reacting solution.

Vassallo, G., H. Dworschak, F. Segantini, and A. Facchini. Application of Denitration/ Oxalate Precipitation in the Petra Hot-Cell Facility.

* The processing system is diagrammed. The competing chemical reactions are discussed, i.e., between oxalate/nitrous/nitric/formic and the role of iron in preventing the complete destruction of the oxalate.

Donato, A. Abatement of the $N O_{x}$ Evolved During Denitration of Reprocessing Concentrate.

* The catalytic induced reaction of ammonia and $\mathrm{NO}+\mathrm{NO}_{2}$ is described:

$$
\begin{aligned}
& 6 \mathrm{NO}_{2} \uparrow+8 \mathrm{NH}_{3} \uparrow \longleftrightarrow 7 \mathrm{~N}_{2} \uparrow+12 \mathrm{H}_{2} \mathrm{O} \uparrow \\
& 6 \mathrm{NO} \uparrow+4 \mathrm{NH}_{3} \uparrow \longleftrightarrow 5 \mathrm{~N}_{2} \uparrow+6 \mathrm{H}_{2} \mathrm{O} \uparrow
\end{aligned}
$$

The reaction proceeds at elevated temperature over hydrogen mordenite (Zeolon $900 \mathrm{H}$, Norton Chemical) $\left(300^{\circ} \mathrm{C}\right.$ to $\left.500^{\circ} \mathrm{C}\right)$. Various processing parameters such as residence time over the catalyst and temperature are studied. Efficiencies as high as $99.5 \%$ are reported.

Cecille, L. and M. Lecomte. Denitration of HLLW for Actinide Partitioning.

* Denitration is performed to condition the waste for other processing steps. (Reactions described are those observed in the standard PVTD slurry processing of Hanford wastes with $\mathrm{HCOOH}$ including noble metal precipitates and catalytic $\mathrm{H}_{2}$ and $\mathrm{NH}_{3}$ generation.) 
Jervis, M. C. Operational Experience of the Denitration of Simulated Highly Active Liquid Wastes During Vitrification.

* Denitration using sucrose and a rotary calciner is discussed. Lithium nitrate and sucrose were added to the liquid waste. The lithium nitrate was added as a calcining conditioner, while the sucrose retarded ruthenium volatility as well as resulting at denitration at lower temperatures.

Jouan, A., J. P. Moncouyoux, and S. Halaszovich. Reduction of Ru and Tc Volatility During Vitrification of HLLW by Denitration.

* $\mathrm{Ru}$ volatility is reduced by prior denitration of a waste or by the addition of sugar to the waste when it is calcined. Formic acid added to the waste and calcined had no effect. Volatilization of Tc is a different problem occurring at temperatures above $600^{\circ} \mathrm{C}$ and chemical reductants appear to have less effect.

Breschet, C.. D. Pageron, F. Drain, V. Decobert. Industrial Application of Denitration of HLLW by Means of HCHO.

* A description of the industrial practice using $\mathrm{HCHO}$ as the denitration agent is described. It has been used for 30 years in three fuel reprocessing plant. . Some incidents are described. Few are reported today. 
Appendix C

Run Observations and Data from Rotary Calciner Tests 


\section{Calciner Testing, Experimental and Observations}

For all tests, the rotary calciner was assembled using a quartz reactor suspended inside a set of clamshell heaters, with size and flights of the reactor varied where indicated. For all of the tests, the speed of the calciner was about $4 \mathrm{rpm}$. The calciner was fitted with a controlling thermocouple at the surface of the clamshell heaters and a monitoring thermocouple in the centerline of the reactor fed in from one of the endcaps. The center thermocouple was angled down slightly so it came into contact with the glass flights and the process material. However, it is expected that much of the duty of this thermocouple was air temperature with the potential of some radiant heat increase from the line of sight of the clamshell heaters.

A gas purge with a helium tracer gas was passed through the reactor, through a bulk particulate filter, and then passed to a gas chromatograph with a thermal conductivity detector and a sampling interval of approximately 90 seconds. The inlet end of the calciner was also fitted with a knockout pot filled with water and venting to a large gas bag to alleviate any extra gas production. The dip tube of the knockout pot was set to different pressure values by adjusting the height of the dip tube in the water.

For all of these tests, a 0.75 inch metal spacer was placed between the two halves of the clamshell heaters. A small video camera was positioned looking into the calciner through this opening, and the calciner was backlit using a portable halogen lamp. Each of the tests was then videotaped.

\section{Calciner \#1, 1/15/98}

The bench-scale quartz rotary calciner was used to perform this experiment on the SBW sludge simulant and reductant. The calciner was fitted with the $\sim 2 \mathrm{~L}$ reactor that has 4 rows of 3 flights each on the inside of the reactor. The reactor was loaded with $7.86 \mathrm{~g}$ of SBW simulant that was prepared on 1/13/98 and which also contained Micro-Cel E. This material was mixed with $1.96 \mathrm{~g}$ of $\mathrm{C} \& \mathrm{H}$ Brand powdered sugar. Air was used as the cover gas along with the helium tracer gas. The knockout pot was set to about 5 "wc and the reactor speed was about $4 \mathrm{rpm}$.

The objective of this test was to operate the system in a most conservative manner in order to examine the behavior of the sludge simulant in the calciner in comparison to the previous tests in non-agitated systems. A slow temperature ramp was used along with frequent data taking efforts in order to carefully note any observable events in the calciner: thermal, pressure, or visual.

The system was started and heating was initiated. The following temperature profile was generated:

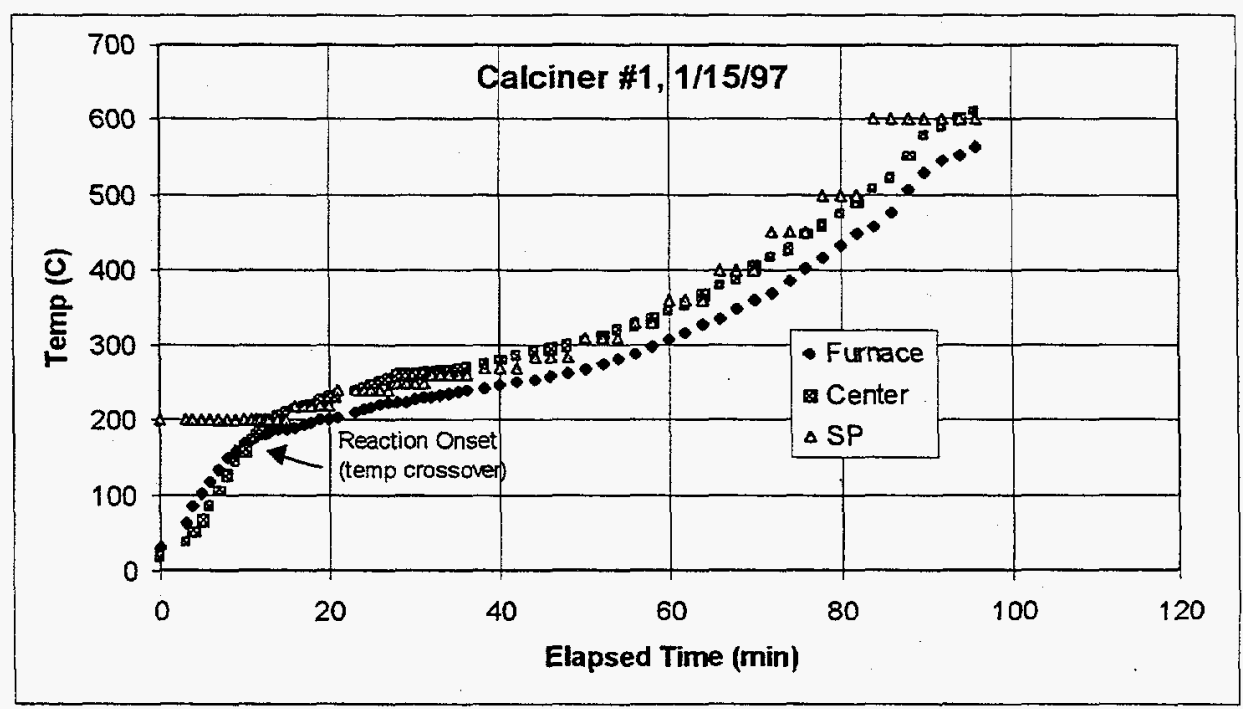


Apparent carmelization of the sugar was visual at $86 \mathrm{C}$ in the furnace and $51 \mathrm{C}$ in the centerline. Heating of the system continued, and there was some visible smoke in the reactor at $174 \mathrm{C}$ in the furnace and centerline. At this event, the inlet gas manometer was observed to peg at over 4"wc pressure and the knockout pot began bubbling. The event lasted from 20 to 30 seconds and it occurred at an elapsed time of 11 minutes. Note on the temperature/time plot that this is the point at which the centerline and the furnace temperatures switched, possibly confirming the presence of an exothermic reaction.

The heat was increased and at a temperature of $186 \mathrm{C}$ in the furnace and 205 in the center, condensate was visible in the outlet arm of the calciner. The temperature of the furnace was ramped up, and throughout the heating process, visual inspection of the reactor contents indicated that the residual material was always loose and free flowing. Temperature was increased slowly over the course of the experiment and the system was eventually halted at $563 \mathrm{C}$ in the furnace and $609 \mathrm{C}$ in the centerline. The residual material was a very fine powder at this point and appeared to be lightly adhered to the reactor wall, but was most likely due to static attraction. Upon cooling the reactor the remaining material appeared to be a very fine, low density powder. $4.8158 \mathrm{~g}$ of product was recovered, which was analyzed at $160,000 \mathrm{ppm}$ nitrate and 100 ppm TOC.

Run Data Sheet:

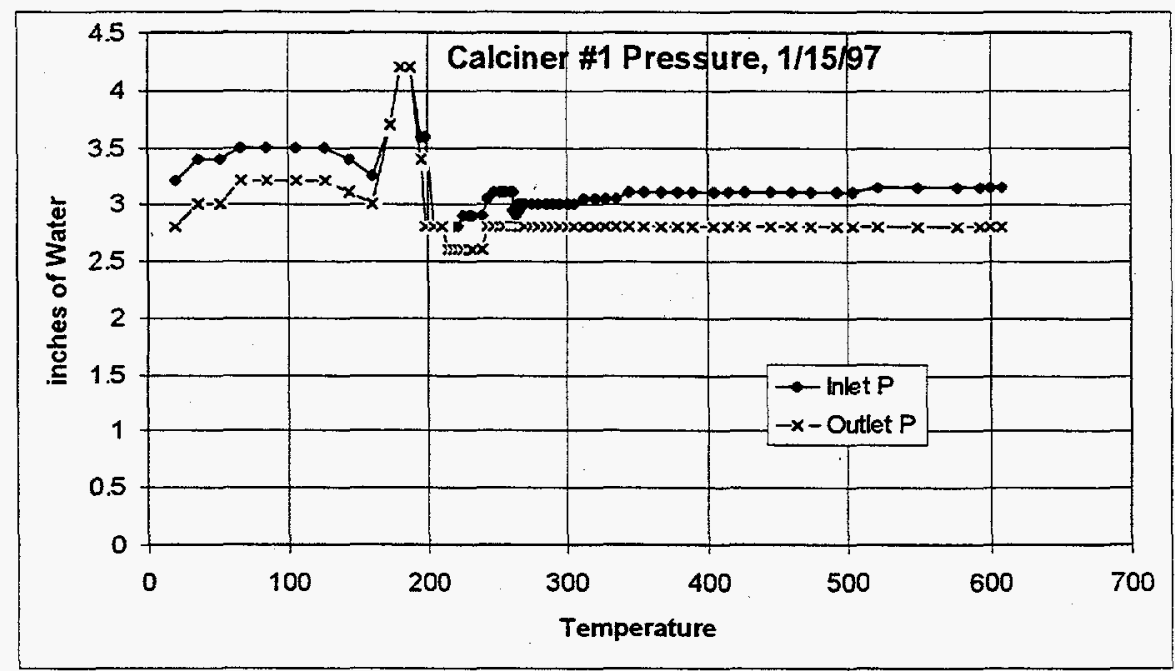

GC data:

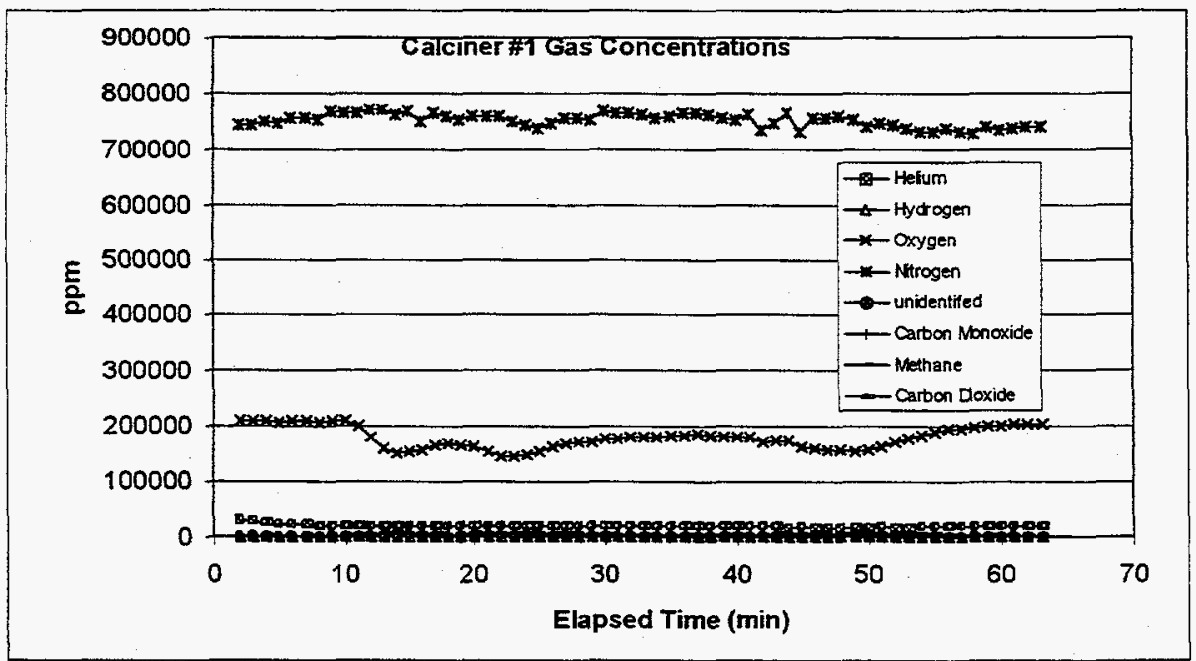




\section{Calciner \#2, 1/16/98}

Upon examining the behavior of the simulant in this reactor, it was decided to perform another experiment at higher reactant loading. In addition, argon was used as a cover gas for the system instead of air. $20.07 \mathrm{~g}$ of SBW simulant was used along with $2.51 \mathrm{~g}$ of C\&H Brand powdered sugar. The SBW used was marked "4:1 SBW Simulant/ Bottoms to Micro-Cel E/ 80.03g SBW simulant/20.00g Micro-Cel E/ 1-15-98. It is known also that the feed matrix was not completely dewatered. For this test, the $\sim 2 \mathrm{~L}$ reactor with 4 rows of flights was used, which was the same one used in experiment\#1. The reactor speed was about 4rpm. The knockout pot was set to about 6"wc.

The approach for this experiment was to use more simulant and apply a faster heatup in order to ensure that the reaction is more easily detectable either visually, thermally, or via pressure changes. The reactor was heated and a temperature profile was generated as follows:

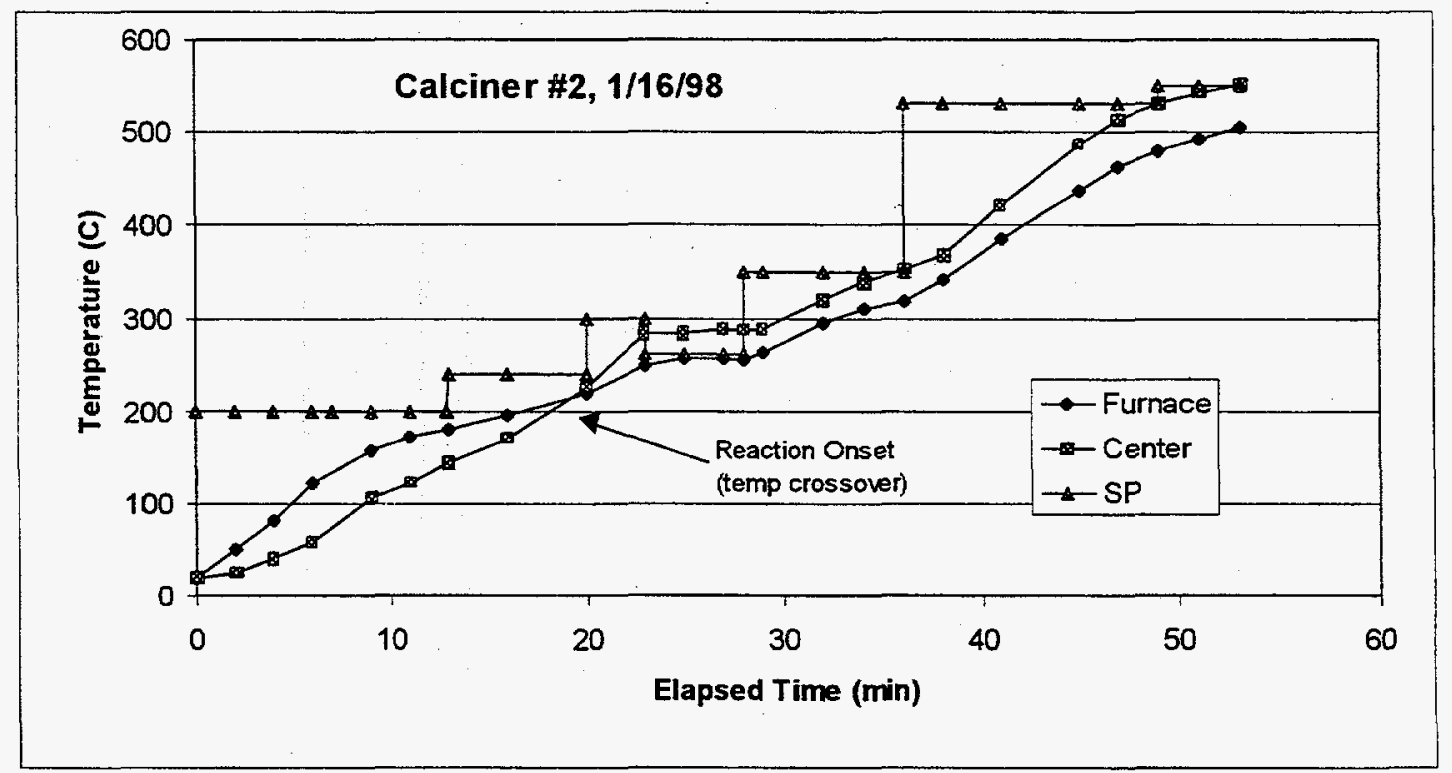

Heatup proceeded normally until at 23 minutes (elapsed time), a furnace temperature of $248 \mathrm{C}$ and a centerline temperature of $283 \mathrm{C}$ a pressure spike occurred. The centerline temperature jumped 26 degrees in 15 seconds, while the temperature increase in the centerline was averaging 3.3 degree increase every 15 seconds for the past minute. At this point, the rubber stopper linkage to the knockout pot popped out of its place, and some sweep gas and reactor vapor effluent was lost. Upon restoring the knockout pot connection, the heatup was continued. Over the course of 30 minutes the temperature was raised to $504 \mathrm{C}$ in the furnace and $551 \mathrm{C}$ in the centerline before being shut down. The solid material recovered was a free flowing large granular material with grain sizes less than $2 \mathrm{~mm} .4 .462 \mathrm{~g}$ of product was recovered, which was analyzed at $1800 \mathrm{ppm}$ nitrate and $1000 \mathrm{ppm}$ TOC. 
Calciner \#2, 1/16/98, Pressure Plot

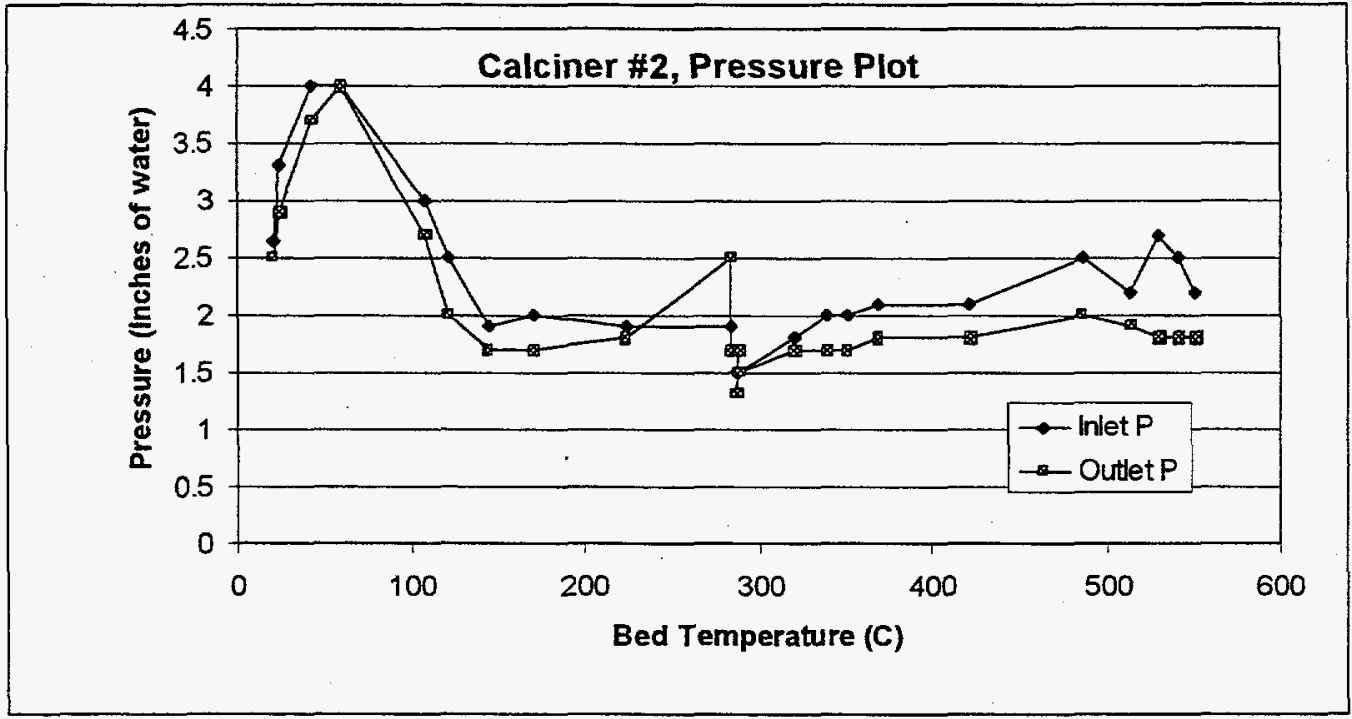

Calciner \#2, 1/16/98, GC Data

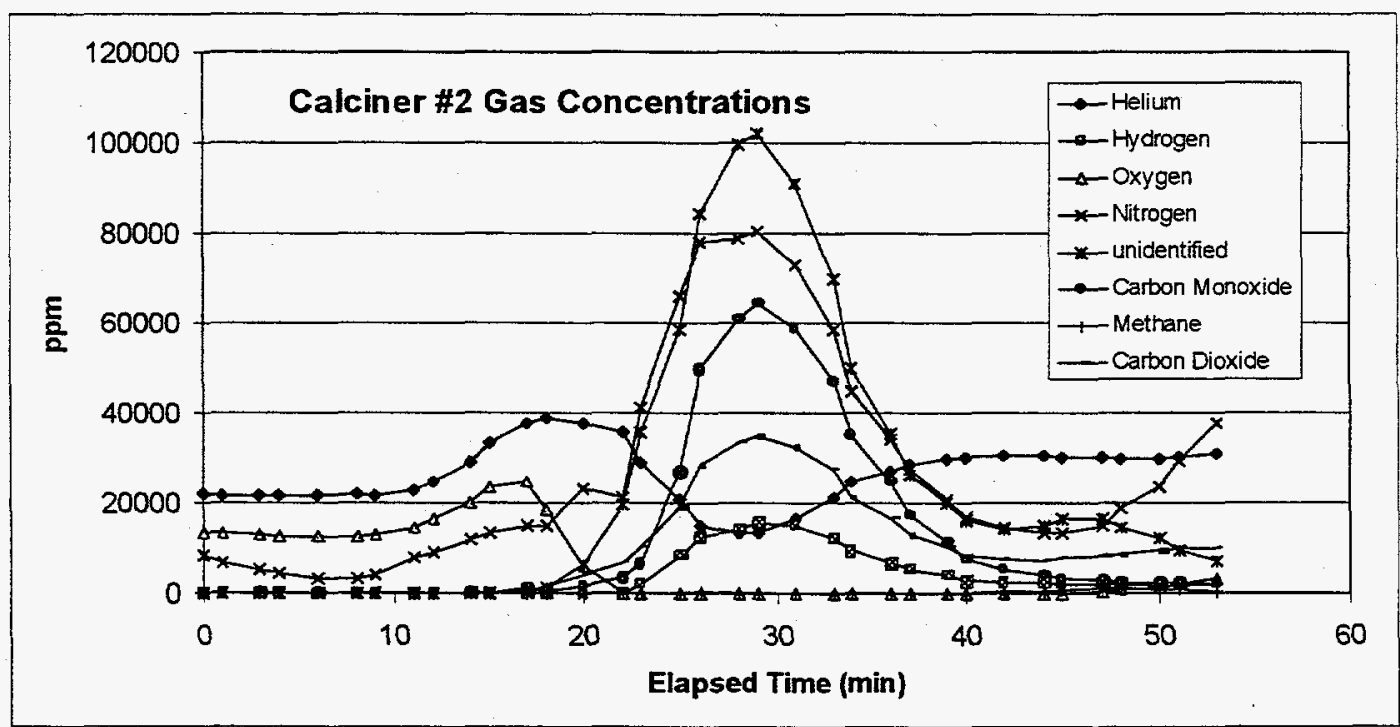




\section{Calciner \#3, 1/18/98}

For the third test, it was decided to observe the effects of using glycolic acid as the reductant in place of sugar. Again, it was decided to use argon as the cover gas to better match the conditions of the second test. $20.07 \mathrm{~g}$ of SBW simulant was added to the reactor from the $1 / 15 / 98 \mathrm{mix}$ which was used in experiment $\# 2$. For this test, the smaller $\sim 1.7 \mathrm{~L}$ quartz reactor that has only one row of 3 flights was used. This did not appear to greatly affect the turnover of the process material due to the fact that the reactor was essentially very lightly loaded with feed. With larger amounts of material it may prove beneficial to use the reactor with more than one row of flights for thorough mixing. The reactor speed was approximately $4 \mathrm{rpm}$. The knockout pot was set to 4 "wc.

Heat up of the reactor proceeded similarly to experiment \#2. The temperature profile was as follows:

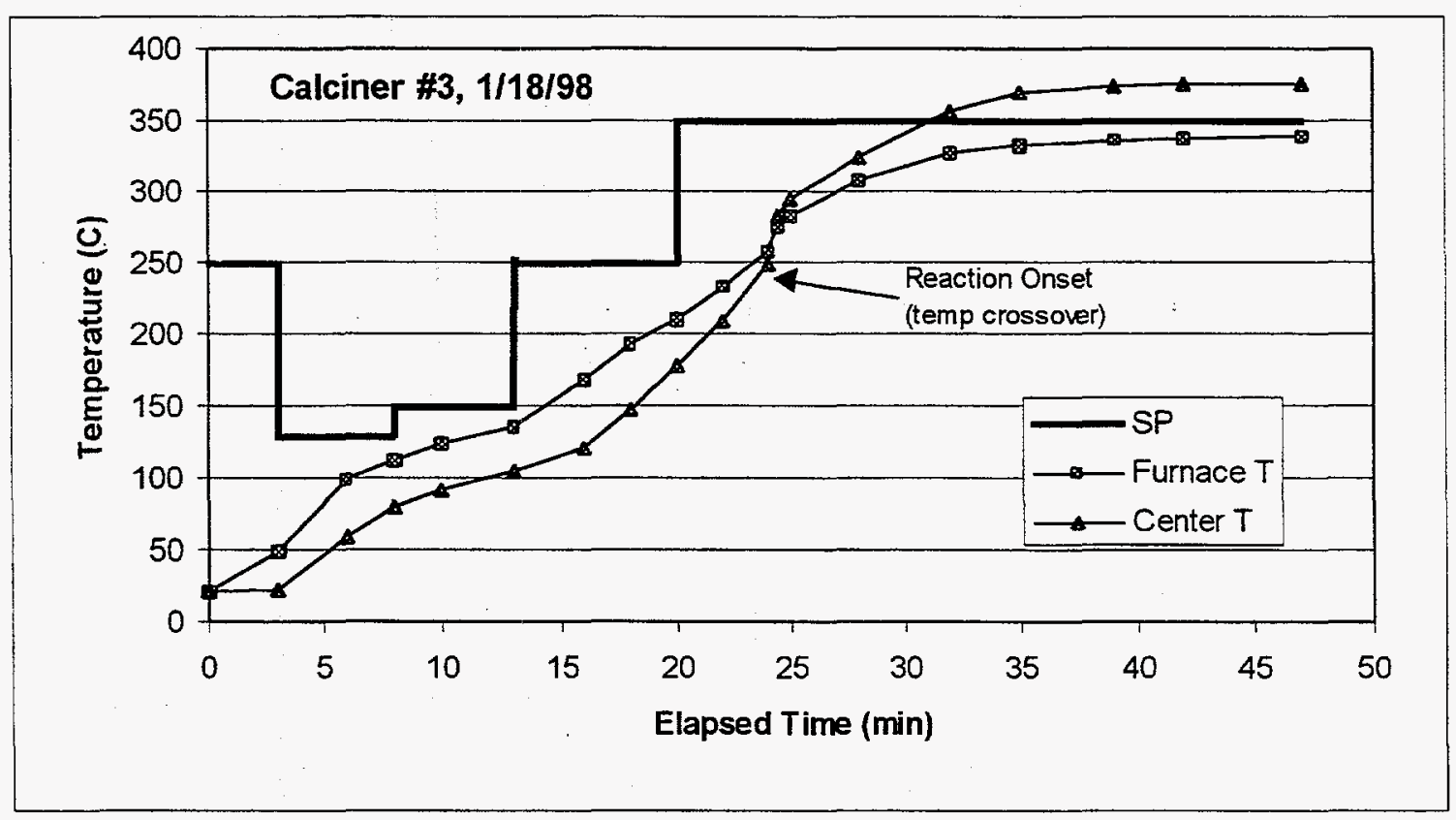

The system was heated fairly aggressively, but was initially held at setpoints of 130 and 150 early in the run to allow for the removal of water in the feed matrix prior to ramping up to higher temperatures. At the elapsed time of 22 minutes, wild swings between 2.5 "-3.5"wc were observed in the inlet manometer while at a furnace temperature of $232 \mathrm{C}$ and a centerline temperature of 208.1C. At the elapsed time of 24.5 minutes, the inlet manometer pegged at over 4"wc and gas discharged into the knockout pot at the inlet side of the reactor. The event lasted about 30 seconds at which point the pressure inside of the reactor went back below3"wc. The reactor was heated further over the next 14 minutes until the furnace temperature was $336 \mathrm{C}$ and the centerline temperature was $375 \mathrm{C}$. The reactor was held at this temperature for 8 minutes and then shut down.

The recovered product from the reactor was again large granular and free flowing. However, the colors of the solids ranged from light brown to white, each grain of material being a fairly uniform color. It is surmised that the difference in product colors was due to not heating the system as high as has been performed in the first two experiments. $6.26 \mathrm{~g}$ of product was recovered, which was analyzed at 66,000 ppm nitrate and $7,200 \mathrm{ppm}$ TOC. 
Calciner \#3, 1/18/98, Pressure Plot

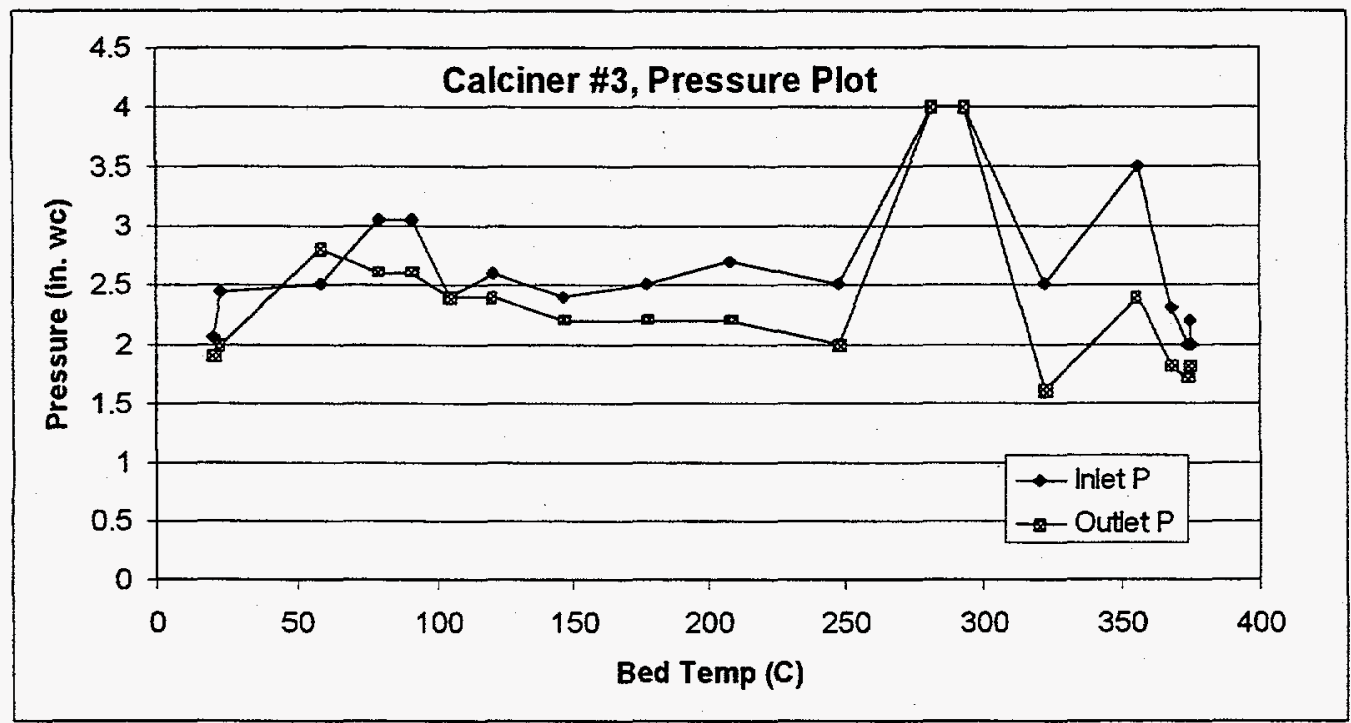

Calciner \#3, 1/18/98, GC Data

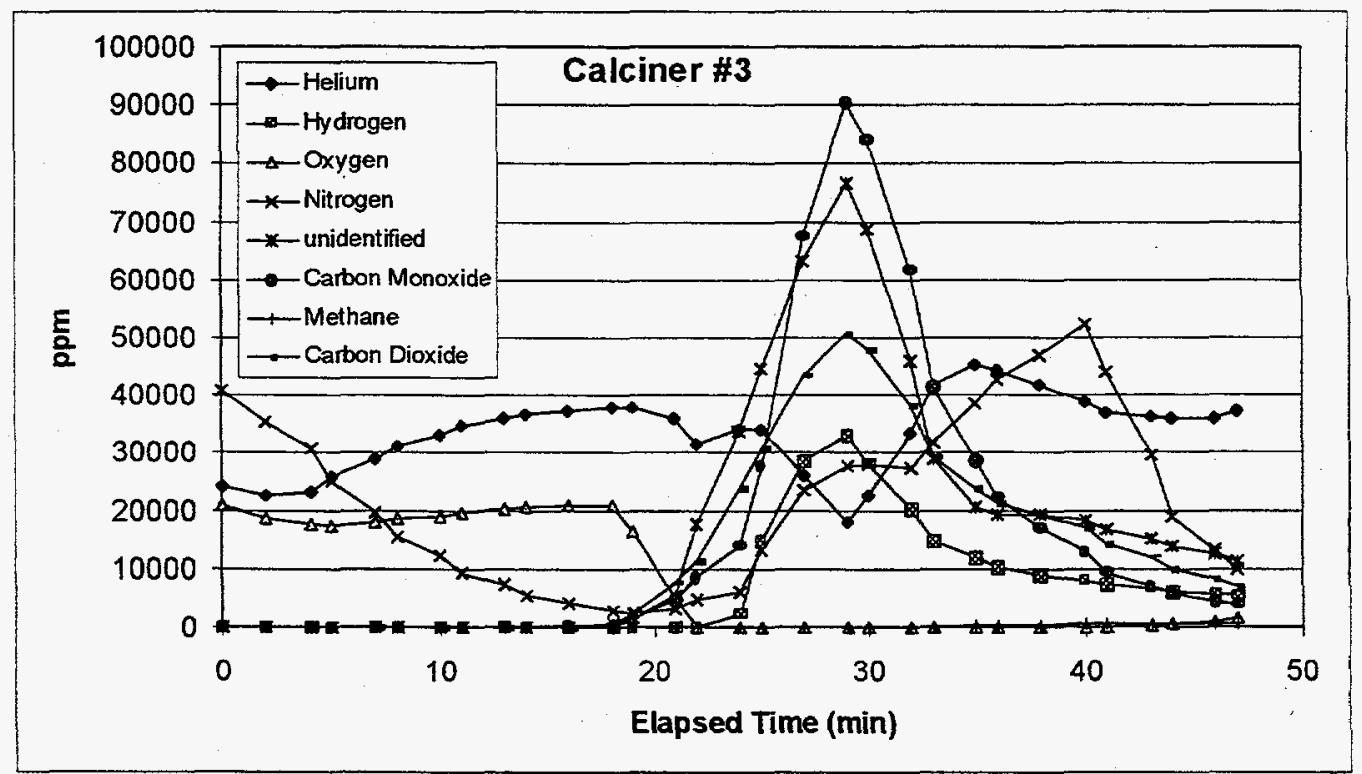


For the fourth experiment, it was elected to load the reactor similarly to the third experiment, but use air as the cover gas. Thus, $28.1 \mathrm{~g}$ of the SBW simulant (1/15/98 mix) was added to the reactor followed by $6.27 \mathrm{~g}$ of glycolic acid. Again, the smaller $\sim 1.7 \mathrm{~L}$ reactor was used with 1 row of three flights. While the materials loading is higher than previous experiments, it was expected that the loading is still light enough not to require the reactor with the four rows of three flights each. Air was used as the cover gas for this test, and the reactor was set to $\sim 4 \mathrm{rpm}$. The knockout pot was set to 4 "wc.

This run was performed heating very agressively with no set point pause to allow for the blow off of the water. The heating profile was as follows.

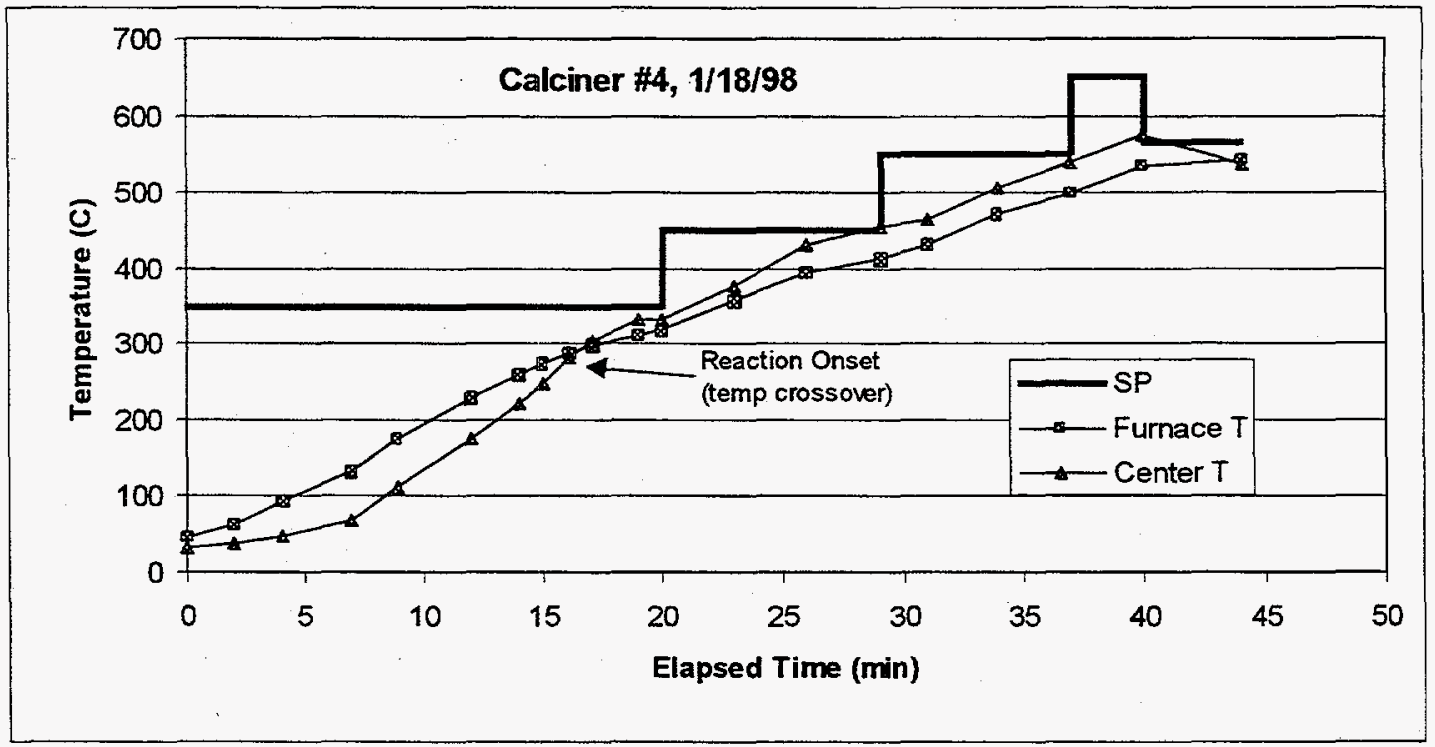

Instead the system was set to $350 \mathrm{C}$ and let to climb rapidly. At an elapsed time of 7 minutes, a furnace temperature of $130 \mathrm{C}$ and a centerline temperature of $67 \mathrm{C}$, some condensate was visible on the exit lines and the manometer was intermittently exceeding 4"wc. At an elapsed time of 15 minutes, the furnace at $276 \mathrm{C}$, and centerline at $248 \mathrm{C}$, the pressure spiked to over 4 "wc on the inlet manometer and a large amount of gas was formed. The knockout pot bubbled during the event for approximately 40 seconds. Following the event, the reactor was heated up further for about 28 minutes. At the end of 28 minutes the furnace was at $541 \mathrm{C}$ and the centerline $535 \mathrm{C}$, at which point it was shut off.

The product was a dry, flowable, granular solid that was light tan to white in color. The color of the product appeared to be slightly lighter than the previous run, but was not the uniform color that was observed in the first experiment. $8.67 \mathrm{~g}$ of product was recovered, which was analyzed at $26,000 \mathrm{ppm}$ nitrate and $1,100 \mathrm{ppm}$ TOC. 
Calciner \#4, 1/18/98, Pressure Plot

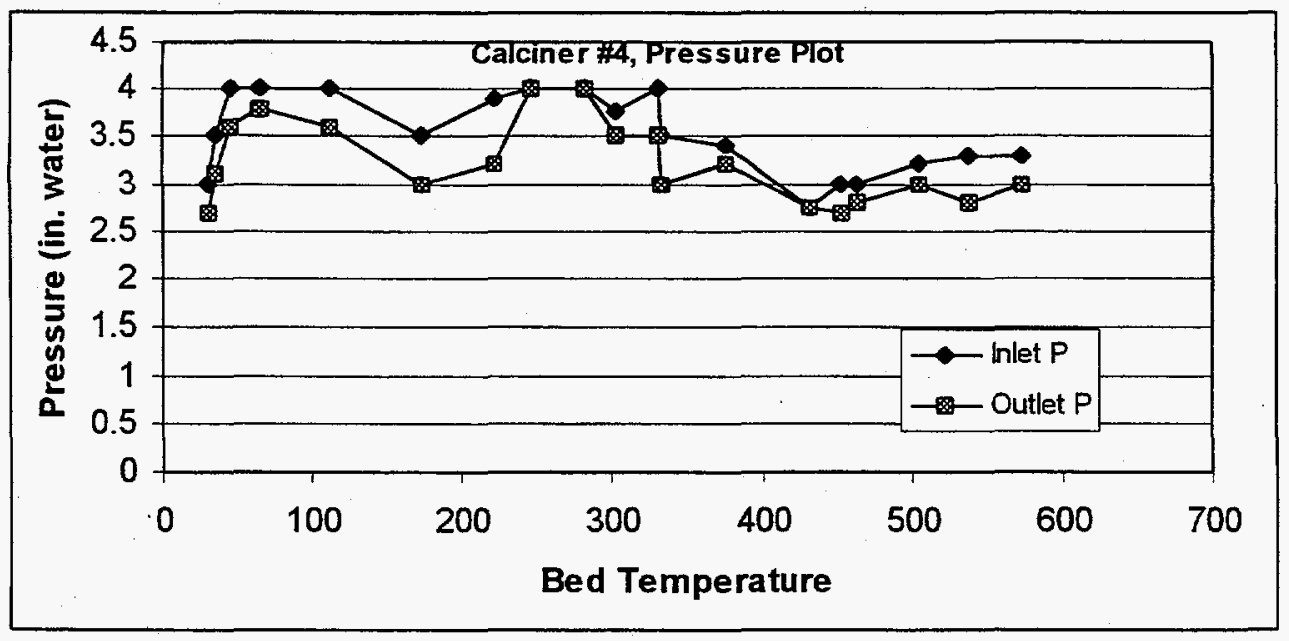

Calciner \#4, 1/18/98, GC Data

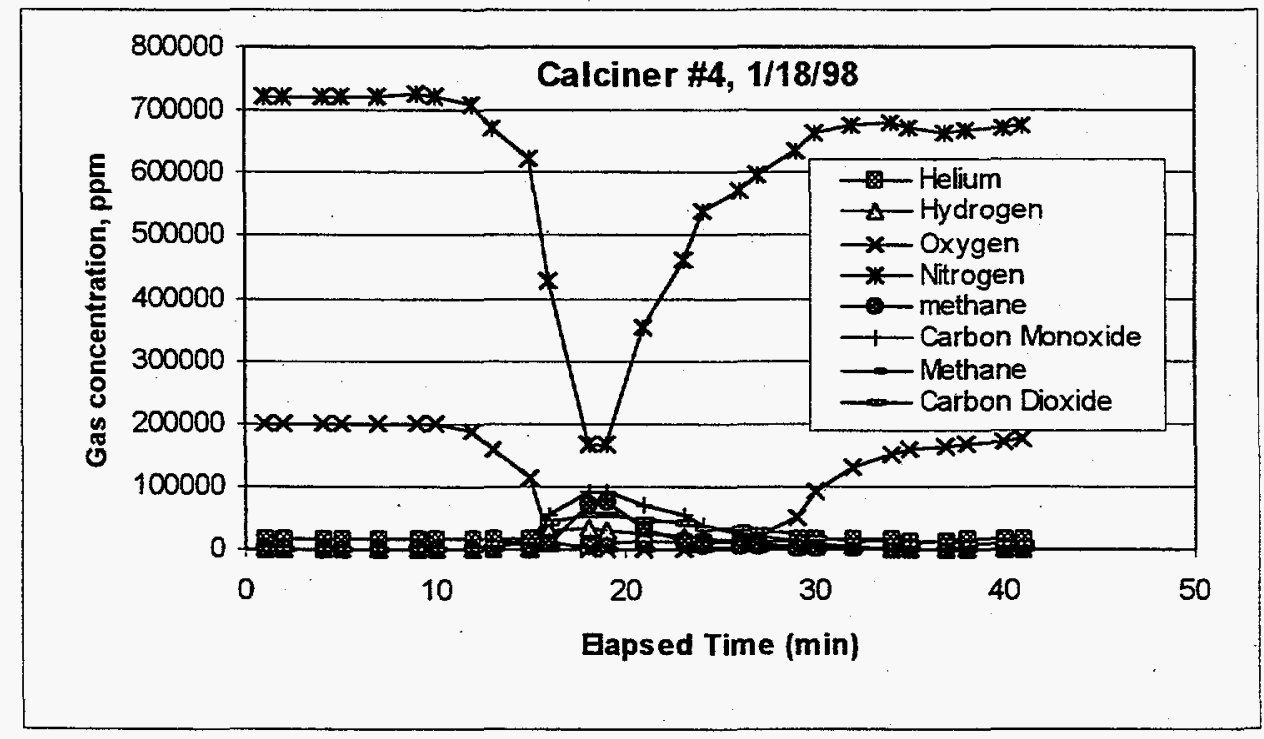




\section{Calciner \#5, 2/10/98}

For this test, significant changes to the system were made. The online GC and sweep gas mass flowmeters were removed and returned to the laboratory that had temporarily supplied them. There was also a need to more accurately determine the amount of gas evolved during the reaction of the substrates. Thus, a small gas rotameter was placed on the inlet of the reactor and was used to measure the argon feed. On the exit portion of the reactor, the exhaust gas was fed to a wet test meter. The gas bubbler/gas bag combo at the inlet and the thermocouple at the outlet side of the reactor were switched. It was noted that the tip of the thermocouple in either position was within 2 " of the center of the calciner in either position. The gas bubbler was then removed, and exit gas was piped directly to the gas bag, which was closed off with a clamp until it was needed. The rotameter was calibrated the using the wet test meter with the reactor in place but not rotating. The resulting calibration was:

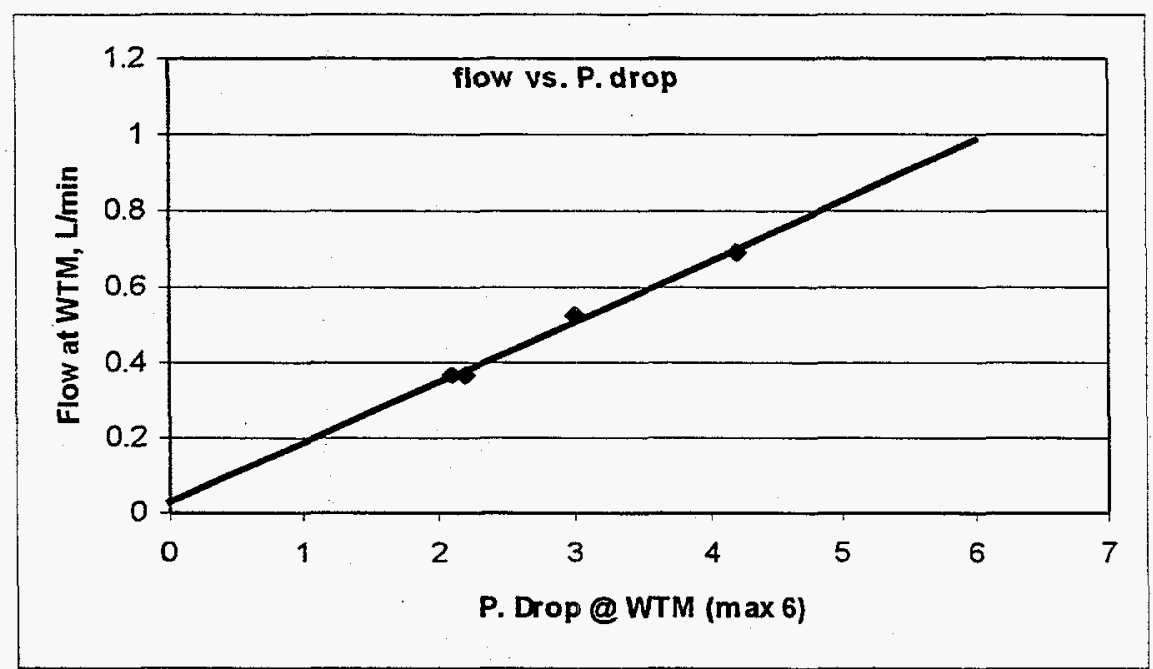

For this test, $26.15 \mathrm{~g}$ of SBW simulant and Micro-Cel E was added to the reactor along with $3.28 \mathrm{~g}$ of powdered sugar. The reactor was assembled, straightened, and purged with argon for more than 20 minutes. The heatup of the reactor was less aggressive than previous tests and was as follows:

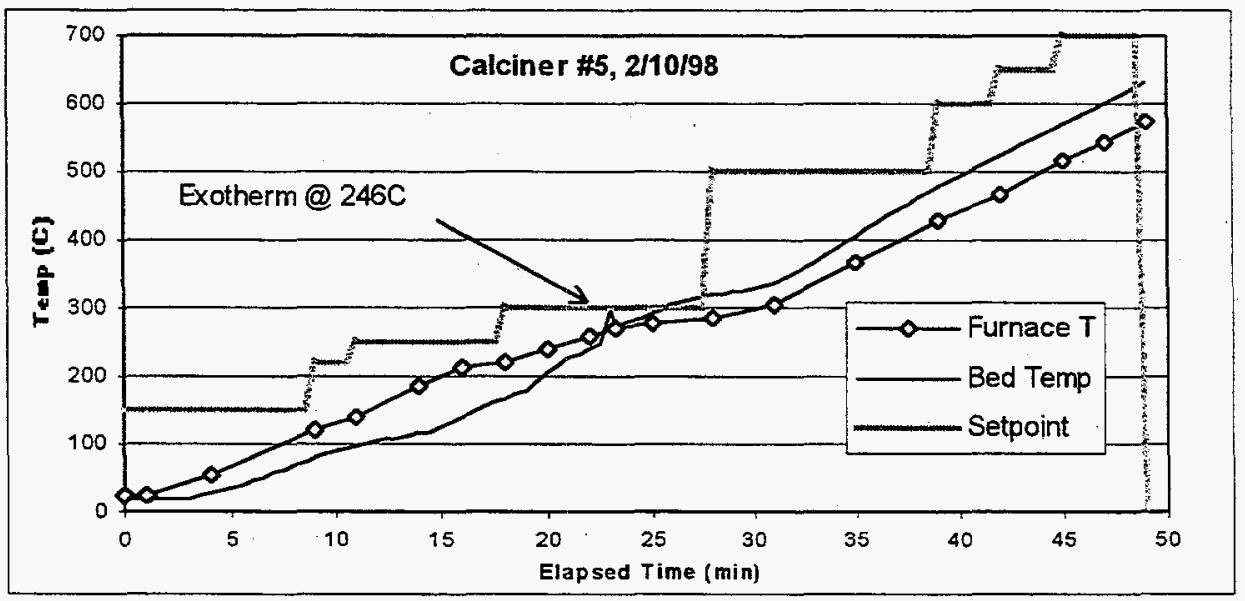

As the temperature profile shows, the clamshell heaters were stepped in small increments so as to ensure that the beginning of the reaction exotherm is more easily detectable and a more accurate reaction ignition temperature can be determined. Heatup was initiated, and condensate was visible at about $80 \mathrm{C}$ in the centerline and $120 \mathrm{C}$ in the furnace. At around $245 \mathrm{C}$ in the furnace, the pressure spiked in the reactor, and the plug to the gas bag dislodged from the port in the reactor. Some of the gas was lost, and then the sample bag plug was placed back into the port. Gas samples were taken from a " $T$ " in the reactor vent line where a septum had been inserted. After the reaction appeared to be over, the reactor heating was 
continued and the final centerline temperature was $629 \mathrm{C}$. At the end of the test, the heaters were shut off, the rotation motor was shut off, and the reactor was allowed to cool with the argon purge.

The material removed from the reactor was a very uniform light gray color and was primarily composed of small granular particulates. The material was light, and flowed easily out of the reactor with only a small amount of dust adhering to the walls. $5.52 \mathrm{~g}$ of product was recovered, which was analyzed at $4,200 \mathrm{ppm}$ nitrate and $310 \mathrm{ppm}$ TOC.

Calciner \#5, 2/10/98, Pressure plot

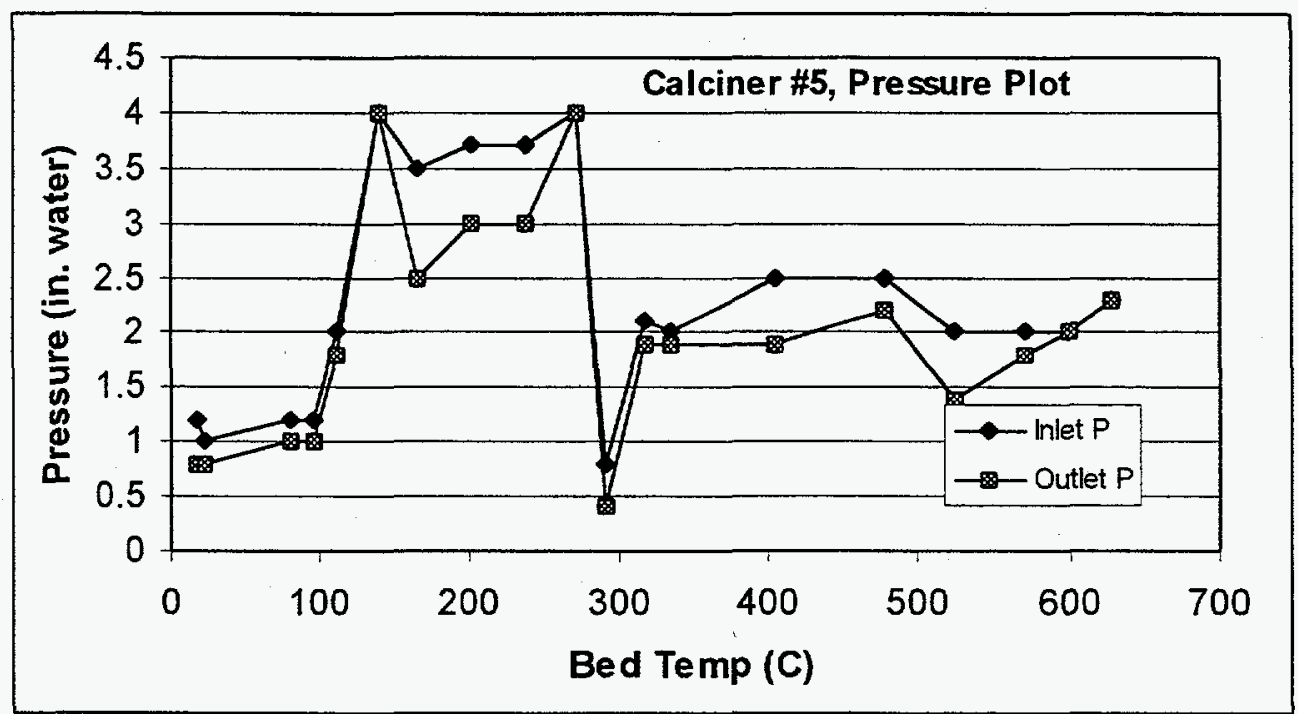


For this test, the reactor was configured similarly to the Calciner \#5 test, except that the 4 "wc bubbler was placed between the reactor and the gas bag at the outlet of the wet test meter. This was replaced to provide acceptable pressure relief for the reactor, as the small diameter offgas line and the wet test meter cannot handle the flow of the offgas during an ignition event.

This test was conducted with the SBW bottoms simulant with flyash as the diluent at the same ratio as has been used previously with MicroCell-E. The feed was prepared by taking liquid SBW bottoms simulant and making a 4:1 simulant to flyash ratio, and then adding $100 \%$ stoichiometric sugar to the still liquid feed. This ensured full dissolution of the sugar into the liquid matrix which allowed for intimate mixing of the nitrates and reductant in solution. The feed was then placed in a vacuum oven and depressureized to around $-25 \mathrm{mmHg}$ and heated to between $50 \mathrm{C}$ and $60 \mathrm{C}$. The feed was dewatered overnight until most of the water was removed. The feed foamed up during drying, and formed a low density solid. The total weight of the undried feed was 20.89 , while the dried feed was $11.27 \mathrm{~g}$. The solid was crushed up with a spatula and weighed out as feed. For this test, $3.5298 \mathrm{~g}$ of the dried simulant/sugar mix was added to the reactor. There was a faint odor of NOx in the jar when it was opened to measure out the feed, but there was no visible brown gas, and the odor quickly dissipated.

The temperature profile was as follows:

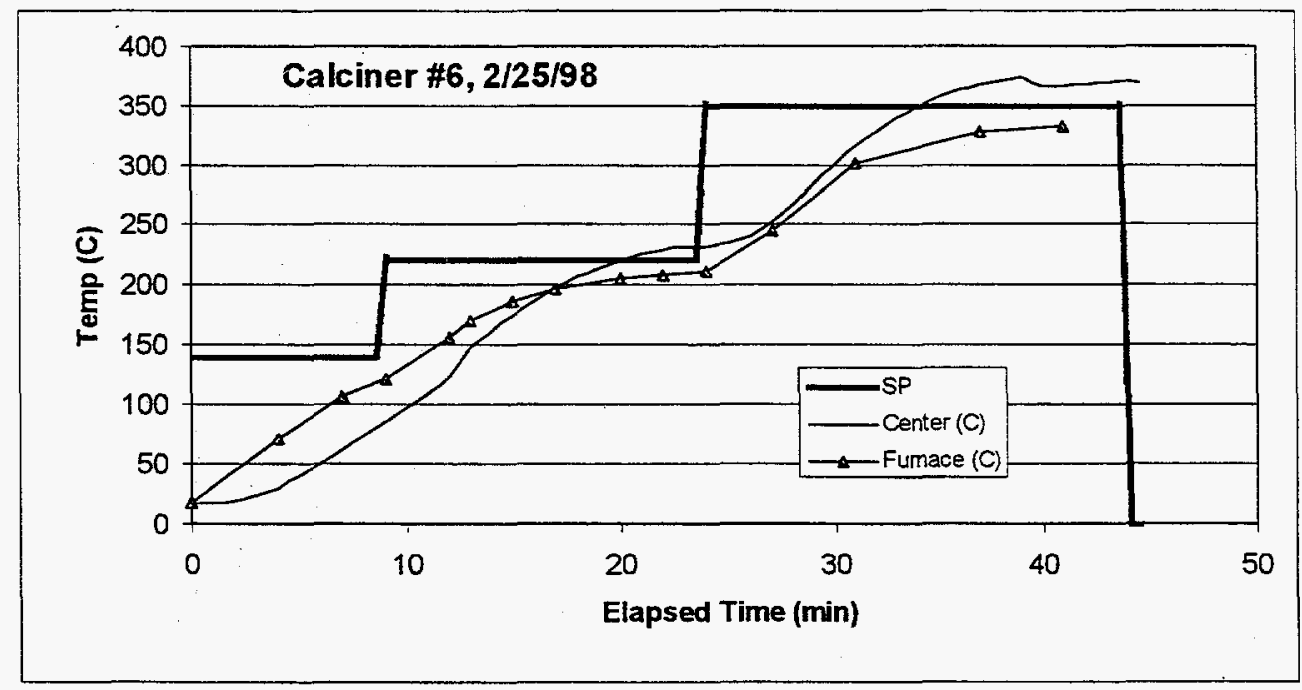

The heatup of the calciner proceeded normally. The reaction appeared to occur 13 minutes into the test, which is earlier than expected, at a centerline temperature of $150 \mathrm{C}$ and a furnace temperature of $160 \mathrm{C}$. The sudden gas evolution within the calciner caused a pressure wave that caused the water to be forced out of a manometer attached to the wet test meter. The unit was quickly refilled. Heating was continued up until a bed temperature of $366 \mathrm{C}$ at which point the test was terminated. $1.34 \mathrm{~g}$ of product was recovered from the test, and analytical results indicated that the material had $11,000 \mathrm{ppm}$ nitrate and $980 \mathrm{ppm}$ TOC. 
Calciner \#6, 2/25/98, Pressure Plot

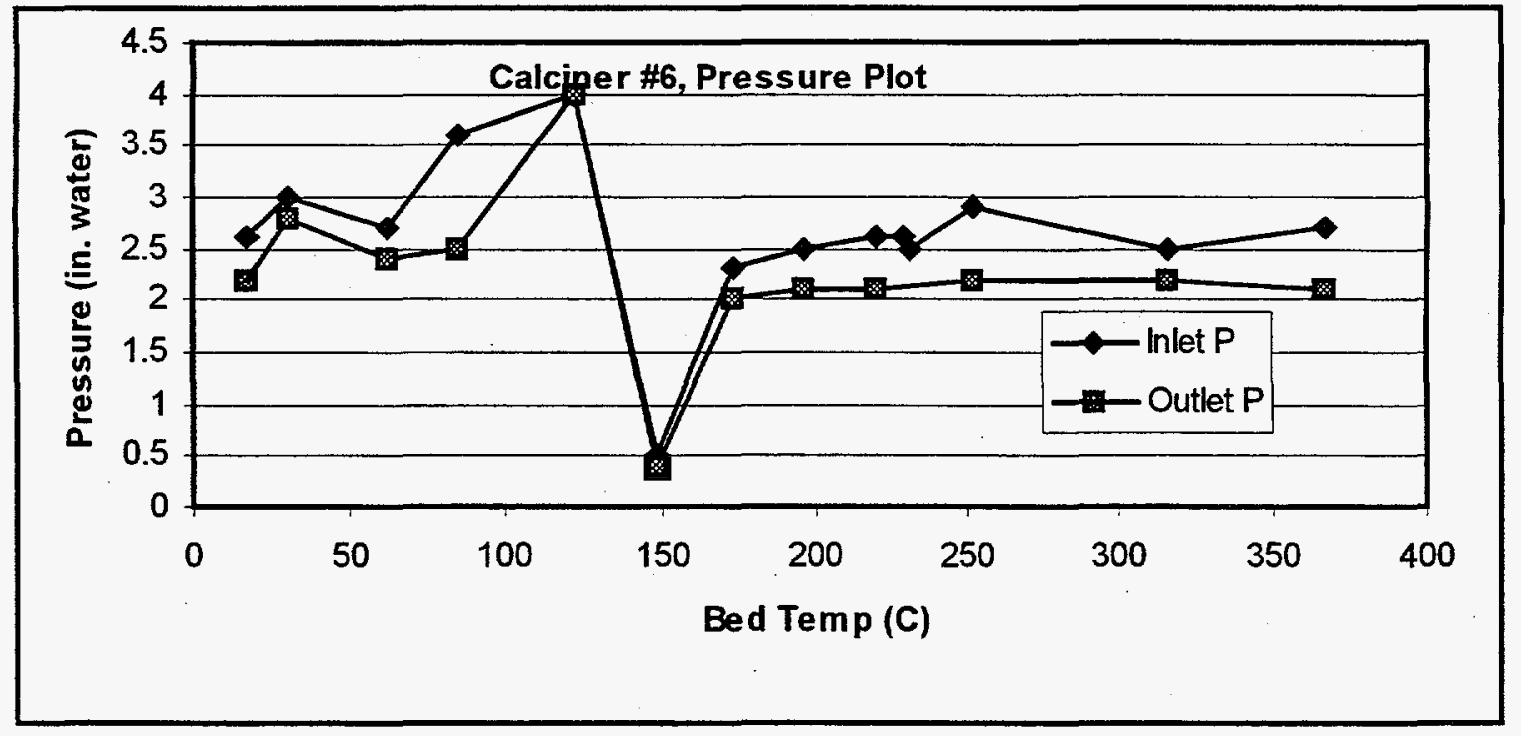


This test was a repeat of Run \#6, thus the reactor configuration remained the same. However, for this test, the normal datalogger was not available and a standard thermocouple reader was used to monitor the bed temperature during the test. The feedstock was taken from the same lot that was prepared and dried for use in run \#6. The solid was once again crushed up with a spatula and weighed out as feed. For this test, $3.6367 \mathrm{~g}$ of the dried simulant/sugar mix was added to the reactor. There was a faint odor of NOx in the jar when it was opened to measure out the feed, but there was no visible brown gas, and the odor quickly dissipated.

The calciner heatup profile was as follows:

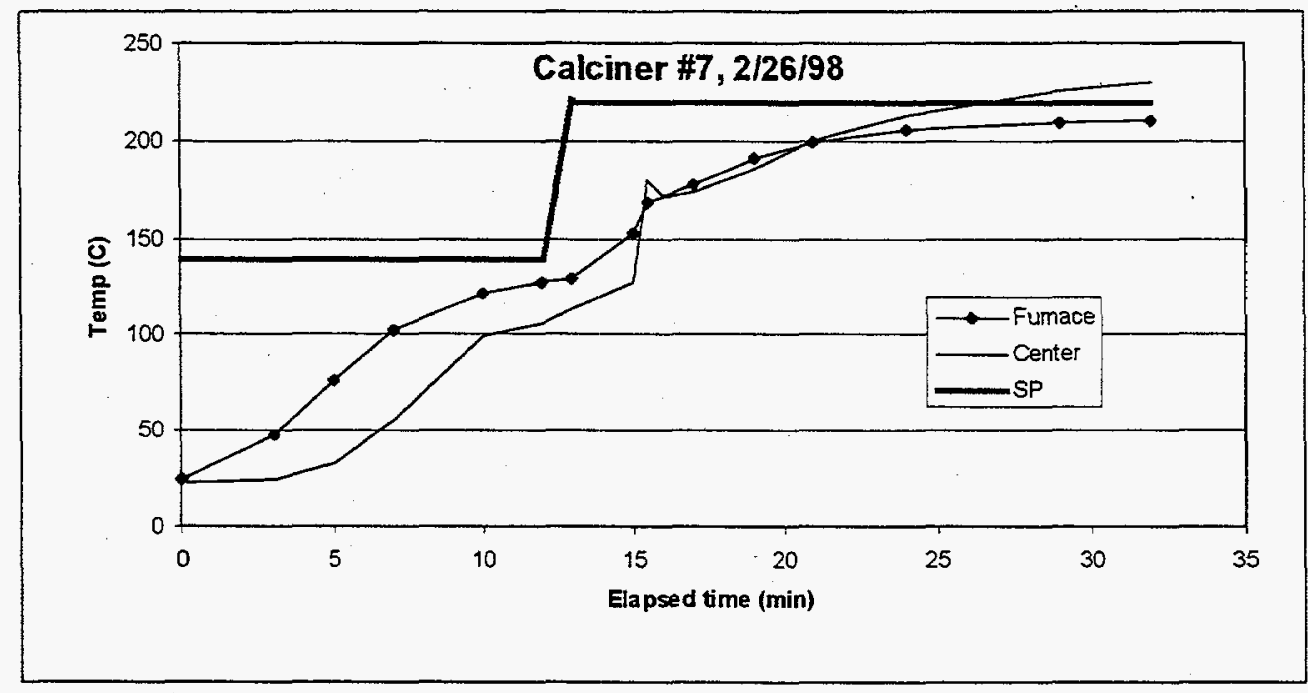

The system was heated normally. At $\mathbf{1 5 . 5}$ minutes, gas evolution from the bubbler indicated that the reaction initiated. This was accompanied by the usual white colored smoke inside the reactor. The reaction jumped up from $135 \mathrm{C}$ to $180 \mathrm{C}$ before falling back down to around $170 \mathrm{C}$ at which point it continued upwards though heating from the furnace. The test was halted at a bed temperature of $232 \mathrm{C} .1 .35 \mathrm{~g}$ of product was recovered from this test, which was analyzed at $28,000 \mathrm{ppm}$ nitrate and $1130 \mathrm{ppm}$ TOC.

Calciner \#7, 2/26/98, Pressure Plot

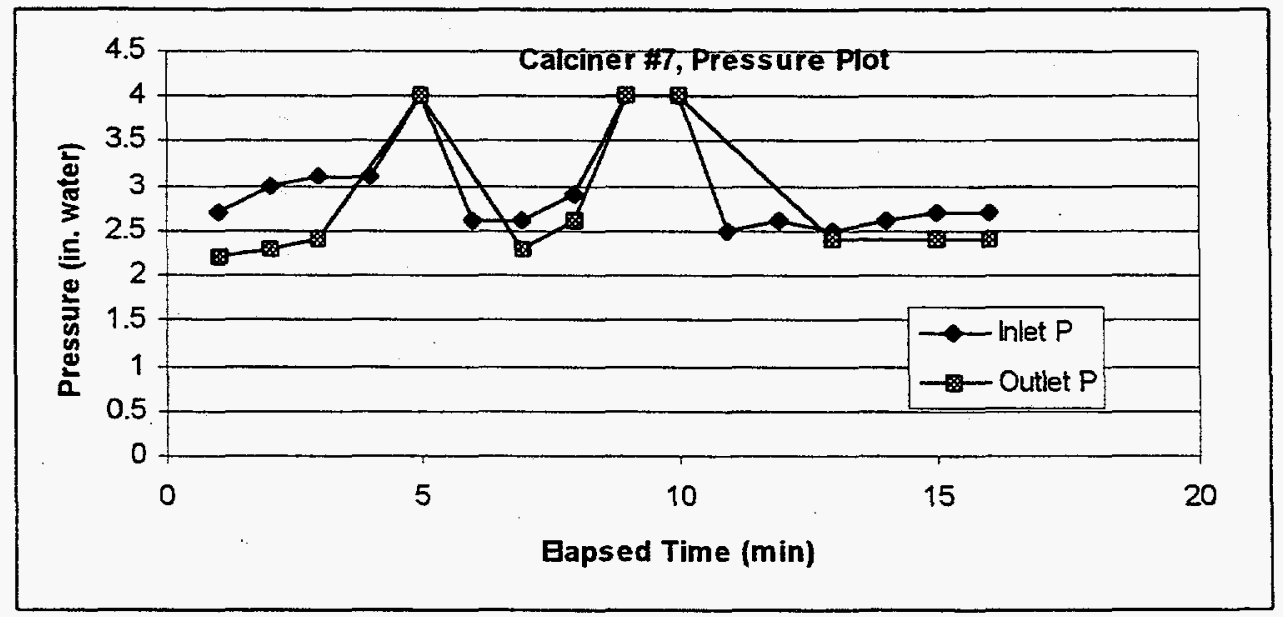


Calciner \#8 was not performed

Calciner \#9, 3/27/98

It was decided to perform this test after an online NOx analyzer was temporarily acquired. The unit output in an analog gauge the real-time level of NOx in the source stream and could be calibrated up to $10 \%$ NOx. The unit required a sweep gas, an oxygen source, and a vacuum pump used to draw a slipstream of the gas product exiting the reactor. The remainder of the exhaust from the calciner was put through the standard sampling system for the portable GC.

The feed used for this test was taken from a jar of feed prepared on 2/11/98 that was a 1:4 mix of Micro Cell-E and the SBW bottoms simulant. $30.4230 \mathrm{~g}$ of this feed was placed in a jar and then vacuum dried at low temperature. After drying, the material weighed $19.8353 \mathrm{~g}$, which indicated that $34.8 \%$ of the mass was removed as water. Of this dried product, $19.7367 \mathrm{~g}(99.5 \%)$ was loaded into the calciner. This represents a total feed loading of $30.2718 \mathrm{~g}$ on an "as-mixed" wet basis, with the standard estimated nitrate concentration of $0.21824 \mathrm{~g}$ nitrate per gram of SBW bottoms $/ \mathrm{MCE}$ mix (4:1). To this, $3.8087 \mathrm{~g}$ of sugar was added which represents approximately the standard stoichiometric loading. The reactor was then assembled and the analytical and data gathering equipment started. The heating profile went as follows:

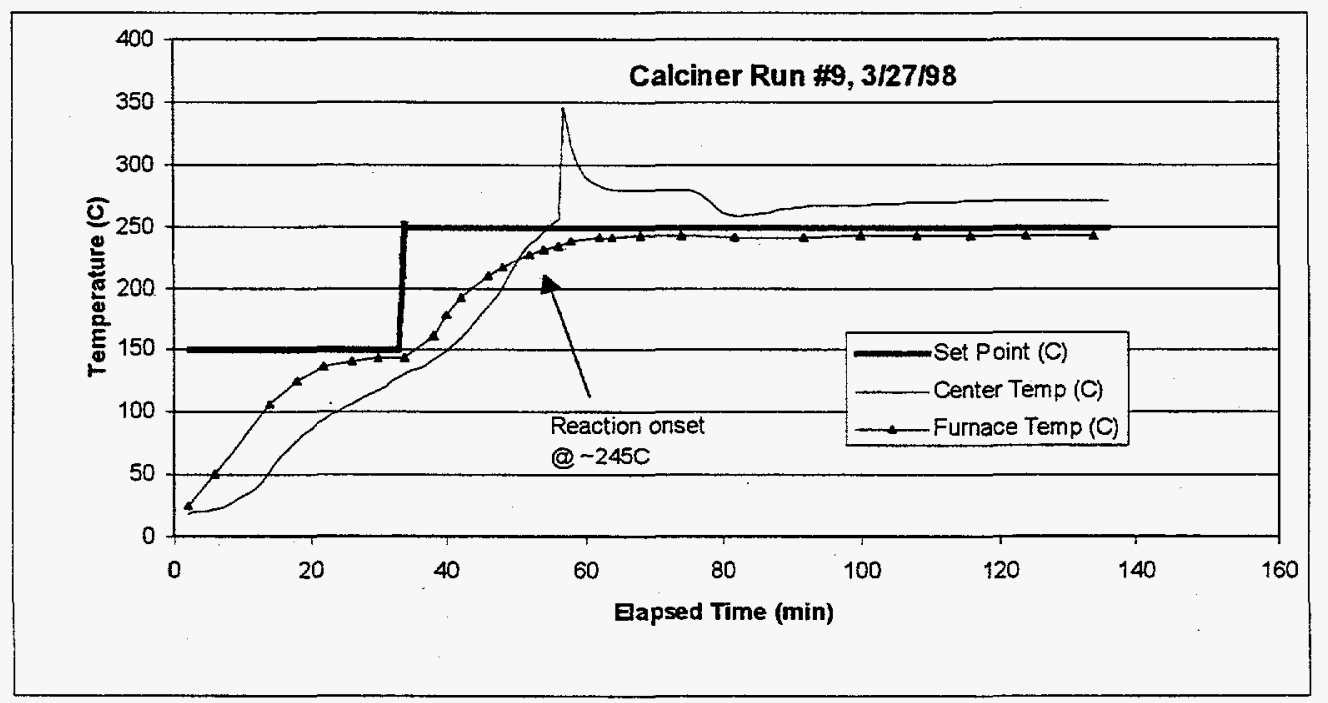

As the reactor was heated, close attention was paid to the NOx analyzer. At an elapsed time of 18 minutes $(160 \mathrm{C}$ in the calciner), the first traces of NOx were detected by the analyzer at $1000 \mathrm{ppm}$. Over nine minutes, the concentration climbed to $74000 \mathrm{ppm}$. At that point, the reaction onset occurred at around $270 \mathrm{C}$. The glass exit line turned immediately a brown-black color, which was presumeably due to the NOx formation. The peak temperature of the calciner bed (as measured every 15 seconds) was $345 \mathrm{C}$. Within 3 minutes, the NOx analyzer gauge was pegged above $100000 \mathrm{ppm}(10 \%)$. The bed temperature fell back down near the furnace temperature, and the furnace was held at $250 \mathrm{C}$. The gauge fell back to scale after an additional 6 minutes. Heatup continued until the bed temperature reached $265 \mathrm{C}$, at which point the run was ended. $7.2446 \mathrm{~g}$ of product was recovered, however it was not analyzed for nitrates or TOC. 
Calciner \#9, 3/27/98, Pressure Plot

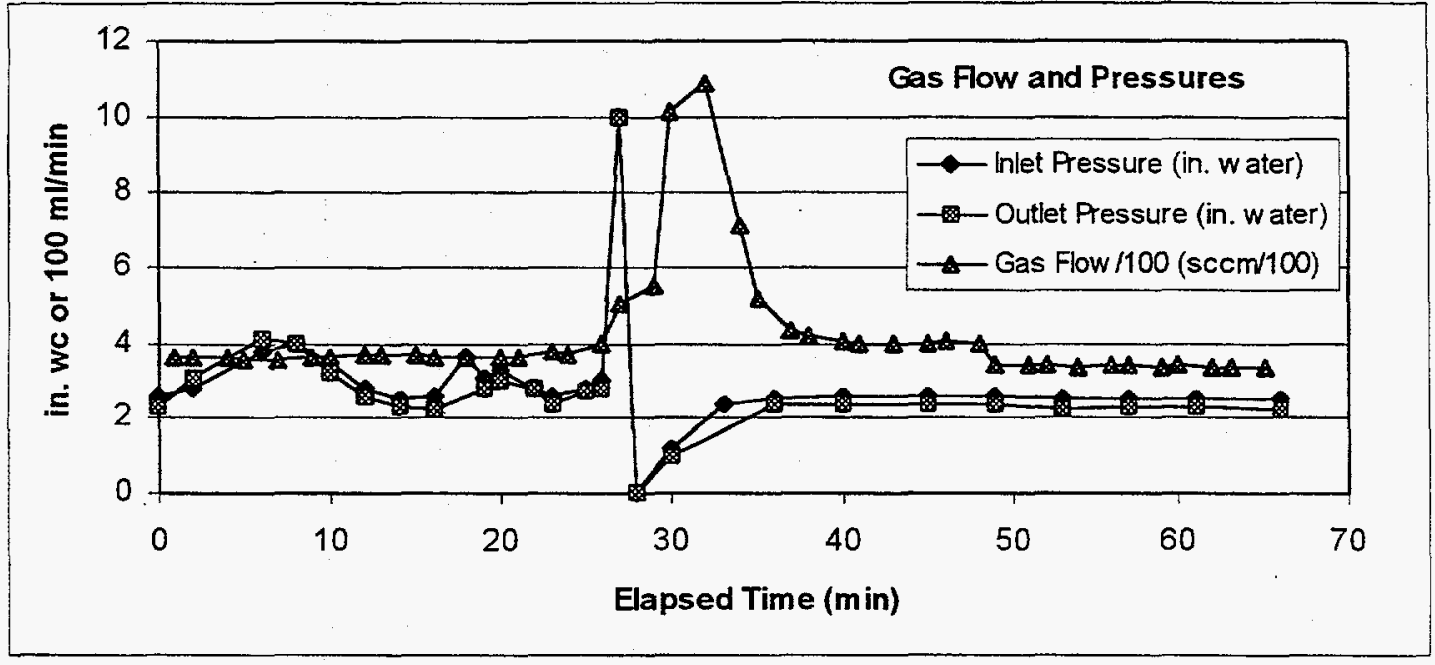

Calciner \#9, 3/27/98, GC data

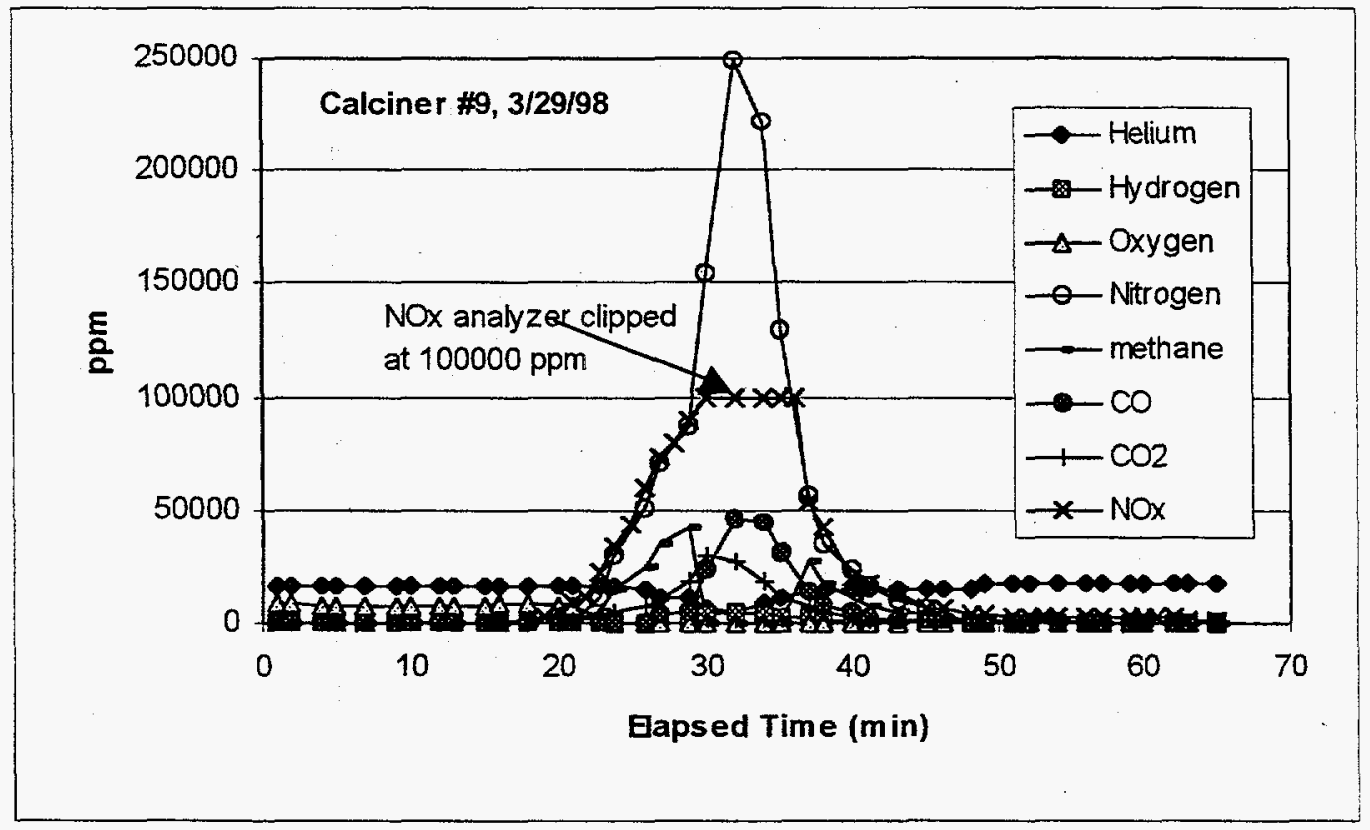


Appendix D

Bibliography 


\section{Appendix D}

\section{Bibliography}

Abe, O., T. Utsunomiya, and Y: Hoshino. 1983. "The Reaction of Sodium Nitrite with Silica." The Chemical Society of Japan 56:428.

Barnes, C. M., D. D. Taylor, and B. R. Helm. 1997. Process Basis Information for the Feasibility Study of the Preferred Alternative for the Treatment of ICCP SBW, Calcine, and LLW. CMB-01-97, Lockheed Martin Idaho Technologies Company, INEEL, Idaho Falls, Idaho.

Beitel, G. A. 1976a. Chemical Stability of Salt Cake in the Presence of Organic Materials. ARH-LD119, Atlantic Richfield Hanford Company, Richland, Washington.

Beitel, G. A. 1976b. Sodium Nitrate Combustion Limit Tests. ARH-LD-123, Atlantic Richfield Hanford Company, Richland, Washington.

Beitel, G. A. 1977. Exothermic Potential of Sodium Nitrate Salt Cake. ARH-LD-163, Atlantic Richfield Hanford Company, Richland, Washington.

Boardman, R. E. 1997. Alternative Calcination Development Status Report. Lockheed Martin Idaho Technologies Company, INEEL, Idaho Falls, Idaho.

Bond, B. D., and P. W. M. Jacobs. 1966. "The Thermal Decomposition of Sodium Nitrate." J. Chem Soc. (A): 1265 .

Bray, L. 1963. Denitration of PUREX Wastes with Sugar. HW-76973 Rev, Hanford Laboratories, General Electric Company, Richland, Washington.

Bray, L. A., and E. C. Martin. 1962. Use of Sugar to Neutralize Nitric Acid Waste Liquors. HW-75565, Hanford Atomic Products Operation, Richland, Washington.

Brickford, D. F., C. J. Coleman, C.-L. W. Hsu, and R. E. Eibling. 1991. "Noble Metal Catalyzed Formic Acid Decomposition, and Formic Acid Denitration." In Ceramic Transactions Nuclear Waste Management $I V$, eds. G. C. Wicks and D. F. Brickford, Westinghouse Savannah River Co, and L. R. Bunnell, Pacific Northwest Laboratory.

Burger, L. L., J. L. Ryan, J. L. Swanson, and L. A. Bray. 1973. Salt Waste Volume Reduction by Sodium Removal. BNWL-B-293, Pacific Northwest National Laboratory, Richland, Washington. 
Burril, K. A. 1987. Chemical Denitration of Aqueous Nitrate Solutions. AECL-9500, Chalk River Nuclear Laboratories, Chalk River, Ontario.

Cecille, L., and M. Kelm. 1986. "Chemical Reactions Involved in the Denitration Process with HCOOH and HCHO," In Denitration of Radioactive Liquid Waste, eds. L. Cecille and S. Halaszovich. Graham \& Trotman, Norwell, Massachusetts.

Chick, L. A., L. R. Pederson, G. D. Maupin, J. L. Bates, L. E. Thomas and G. J. Exarhos. 1990. "Glycine-Nitrate Combustion Synthesis of Oxide Ceramic Powders," Materials Letters, 10:1-2.

Chick, L. A., and G. D. Maupin. 1995. CRADA with Seattle Specialty Ceramics (SSC) and Pacific Northwest National Laboratory (PNL-011): Synthesis and Processing of Ceramic Powder Materials Using the Glycine/Nitrate Process. PNL-10824, Pacific Northwest National Laboratory, Richland, Washington.

Chun, K. S. 1977. "Studies on the Thermal Decomposition of Nitrates Found in Highly Active Waste and of Chemicals Used to Convert the Waste to Glass." AERE-R8735, Chemical Technology Division, AERE Harwell.

Coppinger, E. A. 1963. Pilot Plant Denitration of Purex Waste with Sugar. HW-77080, Hanford Atomic Products Operation, Richland, Washington.

Cox, J. L., M. A. Lilga, and R. T. Hallen. 1992. Thermochemical Nitrate Reduction. PNL-8226, Pacific Northwest National Laboratory, Richland, Washington.

Eaton, W. C. 1995. U.S. Bureau of Mines, Phase 1 Hanford Low-Level Waste Melter Tests: Final Report. WHC-SD-WM-VI-030, Rev. 0, Westinghouse Hanford Company, Richland, Washington.

Eldredge, A. B. 1991. "The Soldis Mixing Model for Scale-Up of the Fluidizer Bed Calcination Process.” Ph.D. Dissertation, Department of Chemical Engineering, University of Idaho.

Evans, T. F. 1959. The Pilot Plant Denitration of PUREX Wastes With Formaldehyde. HW-58587, Hanford Atomic Products Operation, Richland, Washington.

Fluor-Daniel. 1994. Low Level Waste Grout Pilot Plant-Conceptual Design Report. Contract \#04435308, Richland, Washington.

Fluor-Daniel. 1997. ICPP Waste Treatment Facilities Feasibility Study Report. Contract \# 04435336, Richland, Washington.

Forsman, R. C., and G. C. Oberg. 1963. Formaldehyde Treatment of Purex Radioactive Wastes. HW-79622, Hanford Atomic Products Operation, Richland, Washington. 
Gass, W. R., S. V. Dighe, and D. F. McLaughlin. 1993. Plasma Calcination of Simulated High-Level Waste. 93-9TD3-CALCI-R1, Westinghouse Hanford Company, Richland, Washington.

Holze, K., H. Finke, M. Kelm, and W. Deckwer. 1979. "Reaction Model for Denitration with Formic Acid of Waste Effluents from Nuclear Fuel Reprocessing Plants." Chem. Eng. 2.

Hoshino, Y., T. Utsunomiya, and O. Abe. 1981. "The Thermal Decomposition of Sodium Nitrate and the Effects of Several Oxides on the Decomposition." The Chemical Society of Japan 54:1385.

Kelm, M. S., O. S. Drobnik, and W. D. Deckwer. 1980. "Denitration of Aqueous Waste Solutions from the Nuclear Fuel Reprocessing." Nuclear Technology. 51:27-32.

Kozlowski, T. R., and R. F. Bartholomew. 1968. "Reactions Between Sodium Carboxylic Acid Salts and Molten Sodium Nitrate and Sodium Nitrite." Inorg. Chem. 7:2247.

Kubota, M., I. Yamaguchi, and H. Nakamura. 1979. "Effects of Nitrite on Denitration of Nuclear Fuel Reprocessing Waste with Organic Reductants." J. Nucl.Sci. Tech. 16(6).

Kulichenko, V. V., V. A. Savel'ev, V. A. Prokhodtsev, and A. A. Ryabova. 1984. "Calcination of Model High-Level Wastes in a Horizontal Apparatus." Soviet Atomic Energy 56(5): 314-318.

MacDougall, C. S., C. K. Bayne, and R. B. Roberson. 1982. "Studies on the Reaction of Nitric Acid and Sugar." Nuclear Technology 58:47-52.

Marshall, D. W., and R. C. Green. 1996. Sugar Nitrate Interaction and Sugar-Calcine Reactivity Study. Lockheed Martin Idaho Technologies Company, INEEL, Idaho Falls, Idaho.

Meile, L. J., and A. J. Johnson. 1984. Waste Generation Reduction - Nitrates FY 1983 Status Report. RFP-3619, DOE/TIC-4500 (Rev. 72), Rockwell International, Golden, Colorado.

Newby, B. J., and E. S. Dickerson. 1972. ICP-1008, U.S. Atomic Energy Commission (USAEC).

Orebaugh, E. G. 1976. Denitration of Savannah River Plant Waste Streams. DP-1417, E.I. duPont de Nemours and Company, Aiken, South Carolina.

Quinn, J. P. 1911. Mellor's Comprehensive Treatise on Inorganic and Theoretical Chemistry, Vol II, Suppl. II., Wiley and Sons, New York.

Ray, J. D., and R. A. Ogg, Jr. 1956. "A New Method of Preparing Nitric Oxide." J. Am. Chem. Soc. 78:5993.

Rode, T. V., and G. A. Golder. 1956. "Compounds of Constant and of Variable Composition in the Sodium Superoxide- Sodium Oxide System." Chem. Abstr. 50, 12621 e. 
Ryan, J. L. 1995. Redox Reactions and Foaming in Nuclear Waste Glass Melting. PNL-10510, Pacific Northwest National Laboratory, Richland, Washington.

Saum, C. J., L. H. Ford and N. Blatts. 1981. "The Denitration of Simulated Fast Reactor Highly Active Liquor Waste." DCE 7387 (5), Proceedings of the International Seminar on Chemistry and Process Engineering for High Level Liquid Waste Solidification - KFA Jülich (1-5 June, 1981).

Sevigny, G. 1996. Evaluation of Dryer/Calciner Technologies for Testing. PNNL-10979, Pacific Northwest National Laboratory, Richland, Washington.

Smith, H. D., E. M. Tracey, J. G. Darab, and P. A. Smith. 1996. Hanford Low-Level Waste Process Chemistry Testing Data Package. PNNL-11046, Pacific Northwest National Laboratory, Richland, Washington.

Stegen, G. E., and C. N. Wilson. 1996. Vectra GSI, Inc. Low-Level Waste Melter Testing Phase 1 Test Report. WHC-SD-WM-VI-031, Rev. 0, Westinghouse Hanford Company, Richland, Washington.

Sugiyama, K., and T. Takahashi. 1967. "Formation of Nitrogen Oxides by Thermal Decomposition of Sodium Nitrate and Sodium Nitrite in the Presence of Various Oxides," Kogyo Kagaku Zasshi, 70, 1465.

U.S. Department of Energy (DOE). 1998. "SOL GEL PROCESS - Stabilization of High Salt Content Waste," Mixed Waste Focus Area, Innovative Technology Summary Report, U.S. Department of Energy, Office of Environmental Management, Office of Science and Technology, OST Reference \#2036, August 1998.

Wood, R. A. 1997. Transmittal of Cursory Evaluation of HAW and LAW Conditioning Technologies Report. RAW-01-97, Lockheed Martin Idaho Technologies Company, INEEL, Idaho Falls, Idaho.

Zenz, F. A., and D. F. Othmer. 1960. Fluidization and Fluid Particle Systems. Reinhold Chemical Engineering Series, New York. 
Appendix E

Calorimetry Plots from Reaction Calorimeter Testing 
Reaction Calorimetry Test Run 1a

(Run Conditions Provided in Table 5.3) 


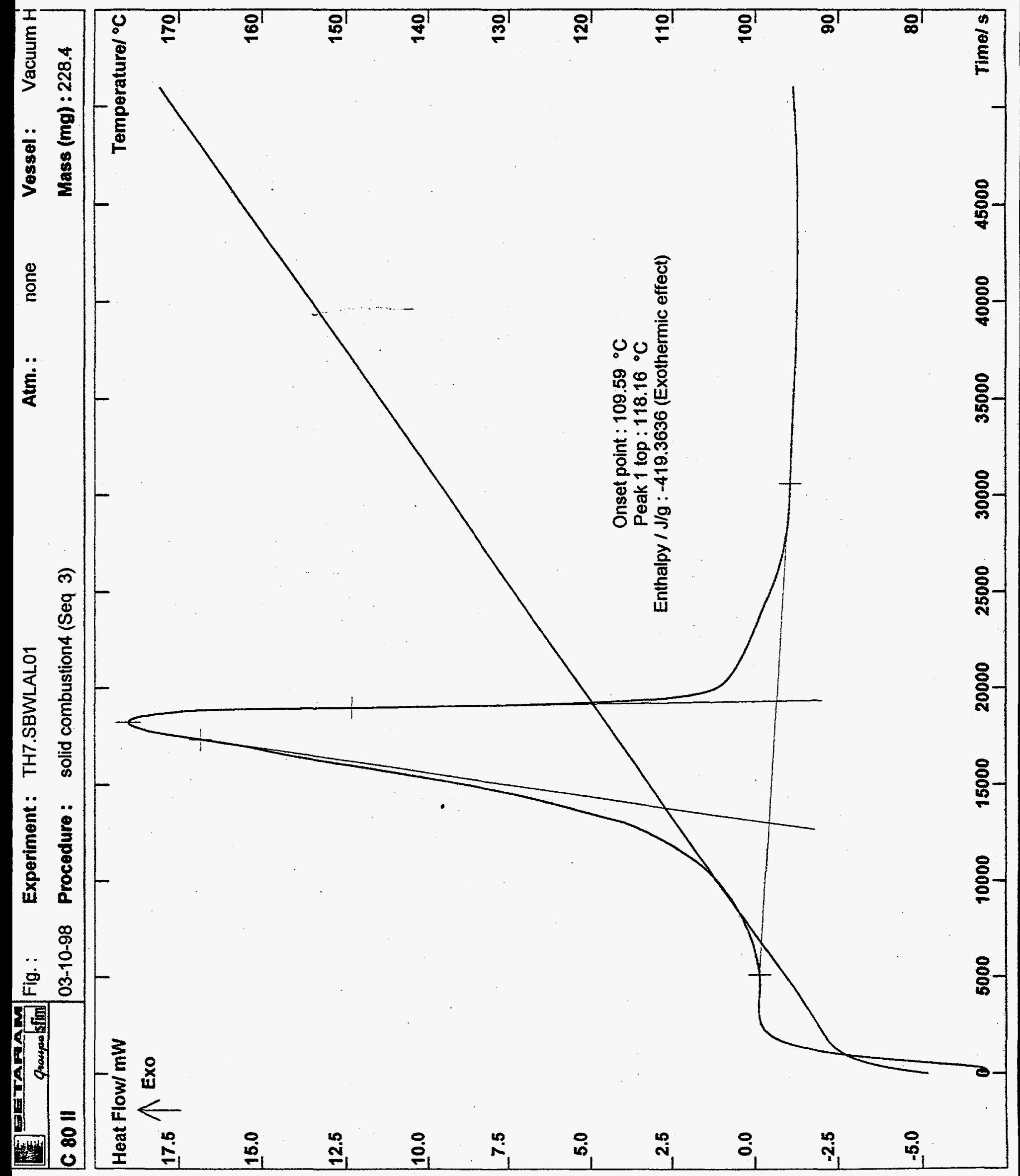




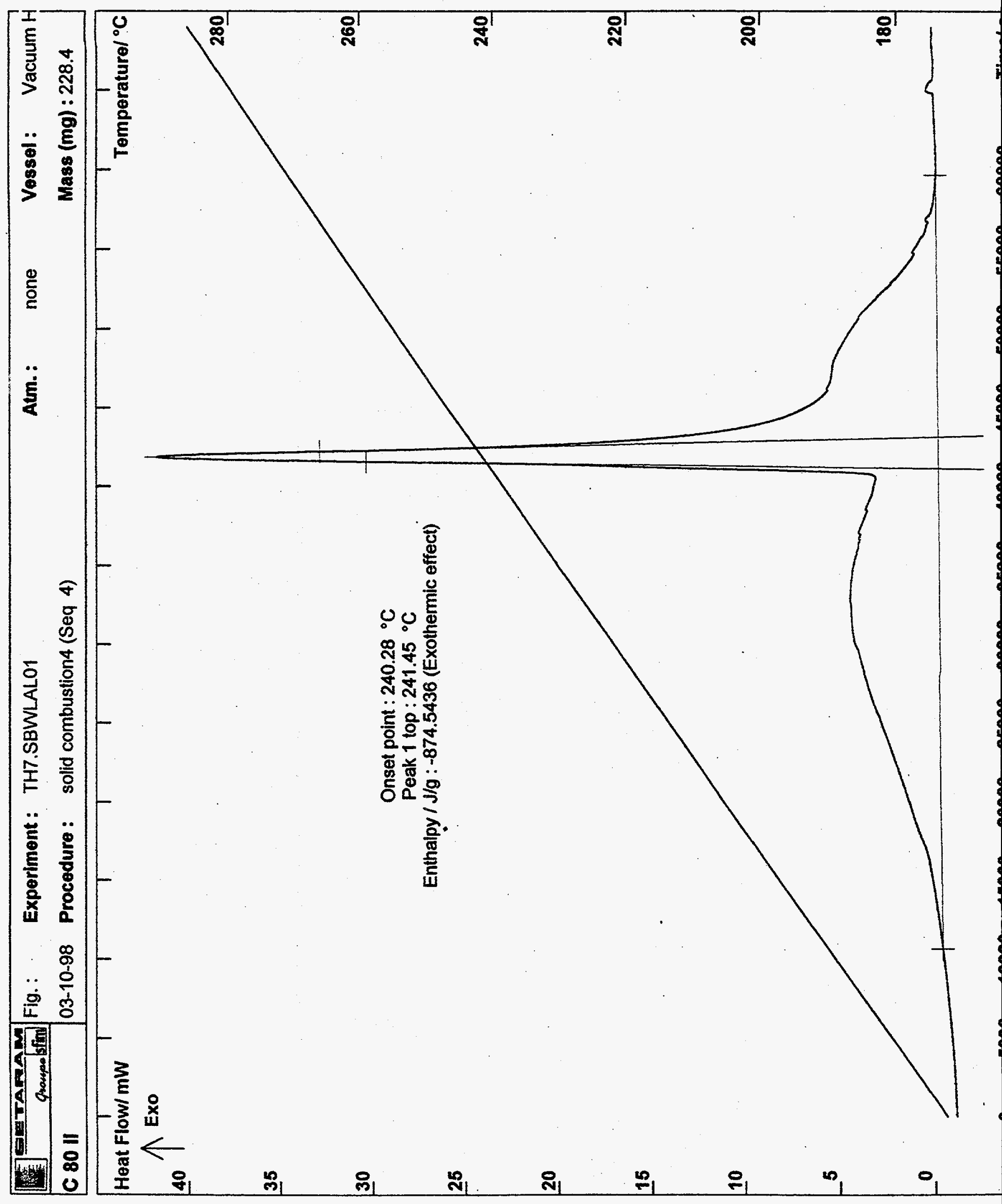




\section{TH7.SBWLAL01}

Standard Collection

PARAMETERS

Device : $\quad$ C 8011 - No option

User: Charlie Group: Todd Hart

Date and Hour: $10 / 03 / 1998-12: 05: 39$

Security $\mathrm{T}^{\circ}$ (Sample) : $300.00^{\circ} \mathrm{C}$

Collection on sample

Stop mode : Pause

Vessel : Vacuum HP Hast

Masse : $228.4 \mathrm{mg}$

Atm. : none

Masse Molaire : $0.0 \mathrm{~g} / \mathrm{mol}$

HF1 Attenuation : $\times 10$ (HF $=+/-20 \mathrm{mV}$ max)

\section{Furnace 1}

$P \cdot=8$

$1=60$

$\mathrm{D}=800$

$U=0$

Security $\mathrm{T}^{\circ}: 300.00^{\circ} \mathrm{C}$

Temperature correction coefficients : $C=B 0+B 1^{\star} T+B 2^{\star} R+B 3^{\star} R^{\wedge} 2\left(T\right.$ and $C$ in ${ }^{\circ} \mathrm{C}, R$ in $\left.K / \min \right)$

$B O=0.0 E+\infty 0$

$B 1=0.0 E+00$

$B 2=0.0 E+00$

$B 3=0.0 E+00$

Sensitivity coefficients $n^{\circ} 1: S=A 0+A 1^{\star} T+A 2^{\star} T^{\wedge} 2+A 3^{\star} T^{\wedge} 3+A 4^{\star} T^{\wedge} 4\left(T=t^{\circ}\right.$ in ${ }^{\circ} C$, s in $\left.\mu V / m W\right)$

$\mathrm{AO}=3.202 \mathrm{E}+01$

$\mathrm{A} 1=4.116 \mathrm{E}-03$

$A 2=-2.382 E-04$

$A 3=6.508 E-07$

$A 4=-7.609 E-10$ 
Standard Collection

SEQUENCES

Device: $\quad$ C 80 II - No option

User: Charlie Group: Todd Hart

Date and Hour: 10/03/1998-12:05:39

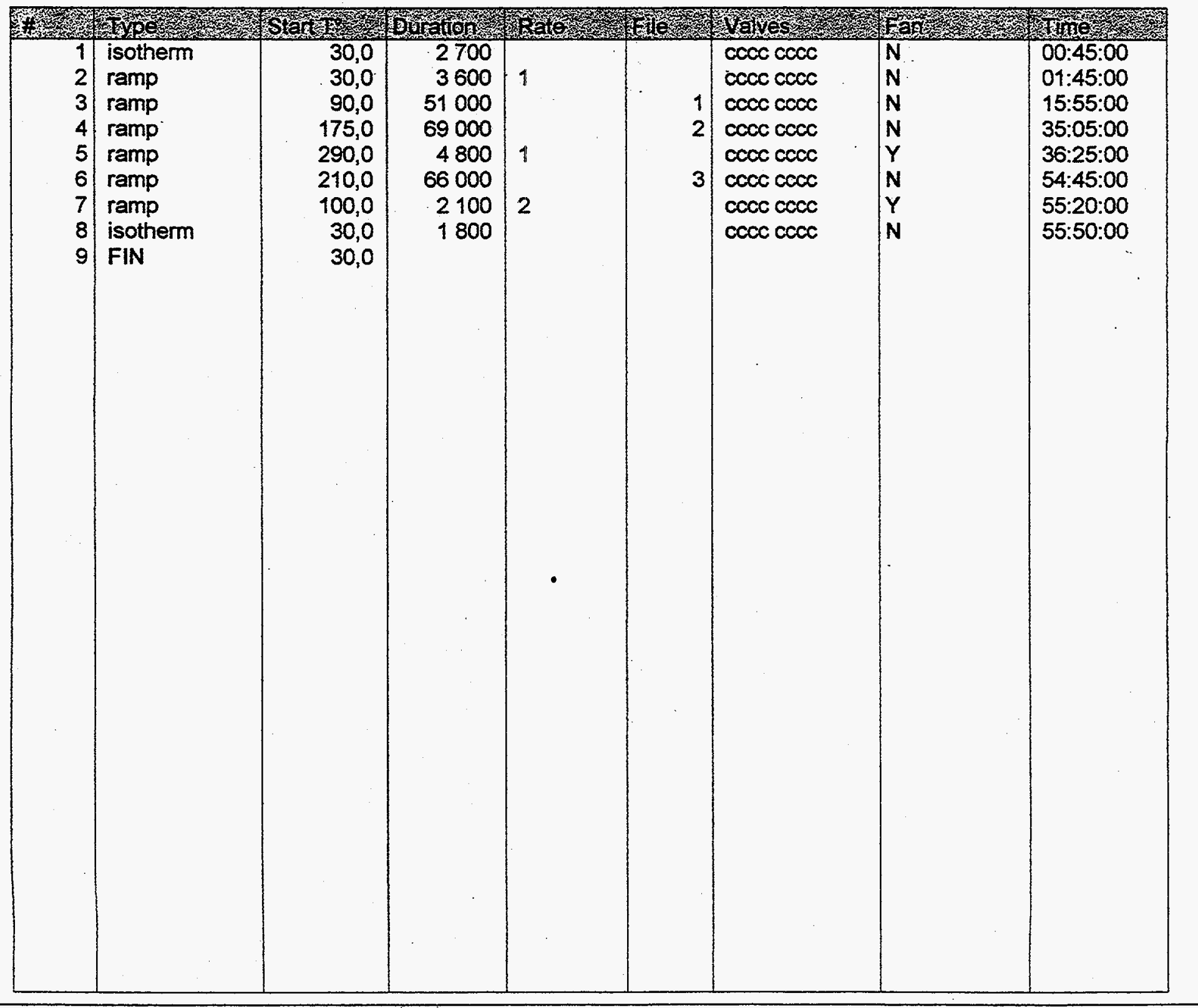


Reaction Calorimetry Test Run $1 \mathrm{~b}$

(Run Conditions Provided in Table 5.3) 


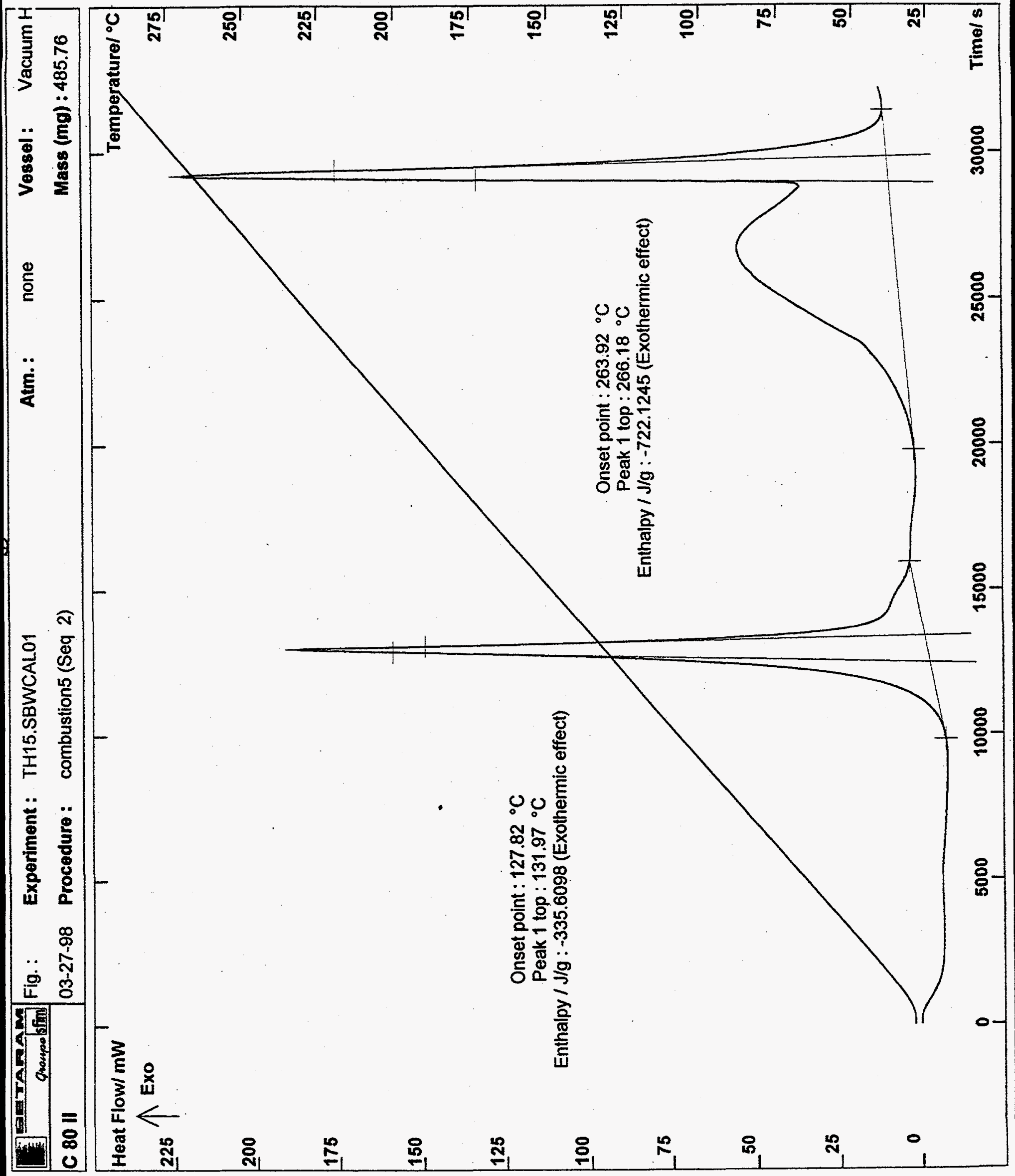




\section{TH15.SBWCAL01}

Standard Collection

PARAMETERS

Device: $\quad$ C $8011-$ No option

User: Charlie Group: Todd Hart

Date and Hour: 27/03/1998-13:13:14

Security $\mathrm{T}^{\circ}$ (Sample) : $305.00^{\circ} \mathrm{C}$

Vessel : Vacuum HP Hast

Atm. : none

Collection on sample

Masse : $485.76 \mathrm{mg}$
Stop mode : Pause

Masse Molaire : $0.0 \mathrm{~g} / \mathrm{mol}$

HF1 Attenuation : $\times 10(\mathrm{HF}=+1-20 \mathrm{mV}$ max $)$

\section{Furnace 1}

$$
\begin{aligned}
& P=8 \\
& I=60 \\
& D=800 \\
& U=0
\end{aligned}
$$

Security $\mathrm{T}^{\circ}: 305.00^{\circ} \mathrm{C}$

Temperature correction coefficients : $C=B O+B 1^{\star} T+B 2^{\star} R+B 3^{\star} R^{\wedge} 2\left(T\right.$ and $C$ in ${ }^{\circ} C, R$ in $\left.K / m i n\right)$

$B O=0.0 E+00$

$B 1=0.0 E+00$

$B 2=0.0 E+00$

$B 3=0.0 E+00$

Sensitivity coefficients $n^{\circ} 1: S=A O+A 1^{\star} T+A 2^{\star} T^{\wedge} 2+A 3^{\star} T^{\wedge} 3+A 4^{\star} T^{\wedge} 4\left(T=t^{\circ}\right.$ in ${ }^{\circ} \mathrm{C}, S$ in $\left.\mu V / m W\right)$ $A O=3.202 E+01$

$A 1=4.116 E-03$

$A 2=-2.382 E-04$

$A 3=6.508 E-07$

$A 4=-7.609 E-10$ 
Standard Collection

SEQUENCES

Device: $\quad$ C 80 II- No option

User: Charlie Group: Todd Hart

Date and Hour: 27/03/1998-13:13:14

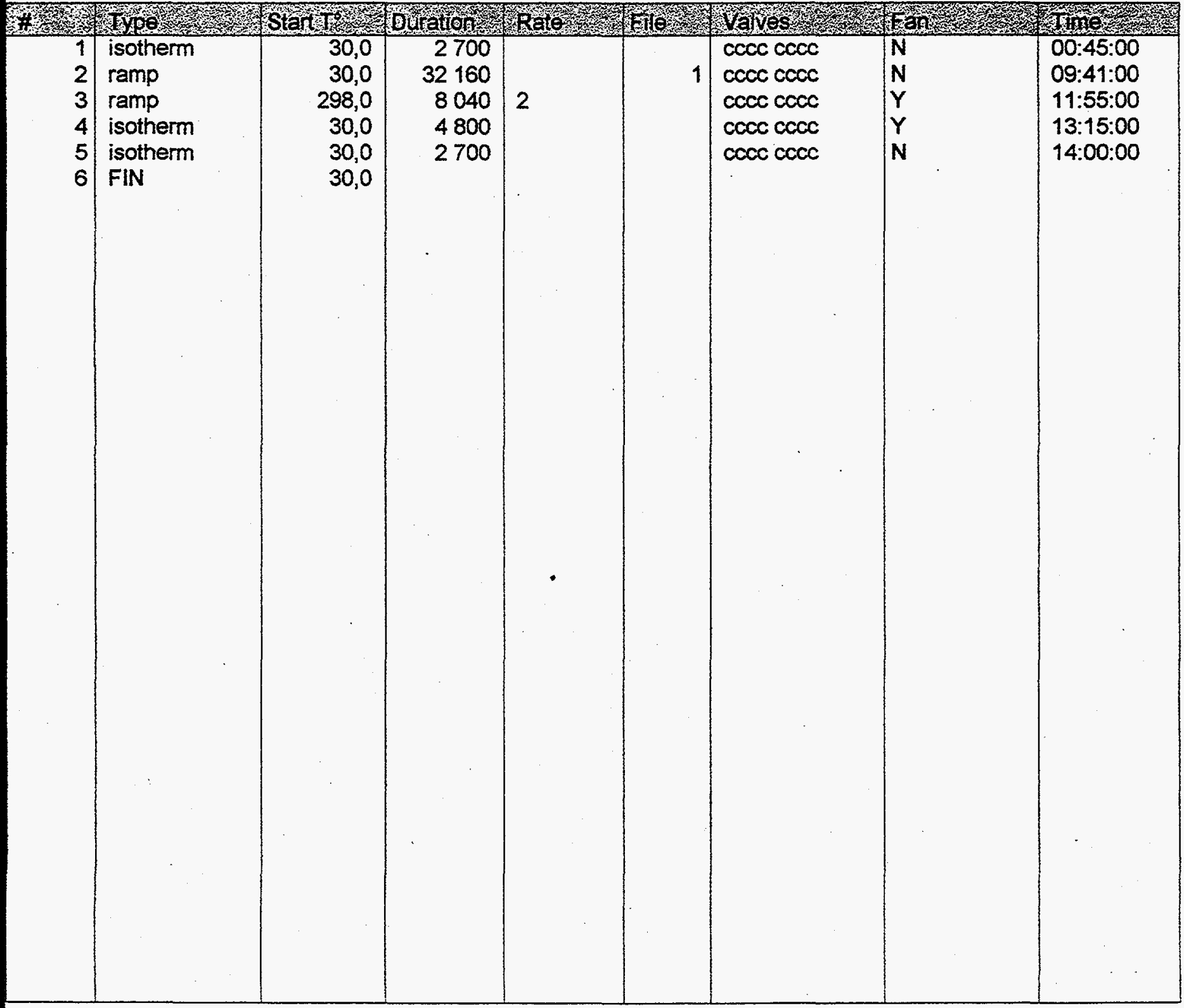




\section{Reaction Calorimetry Test Run 2a}

(Run Conditions Provided in Table 5.3) 


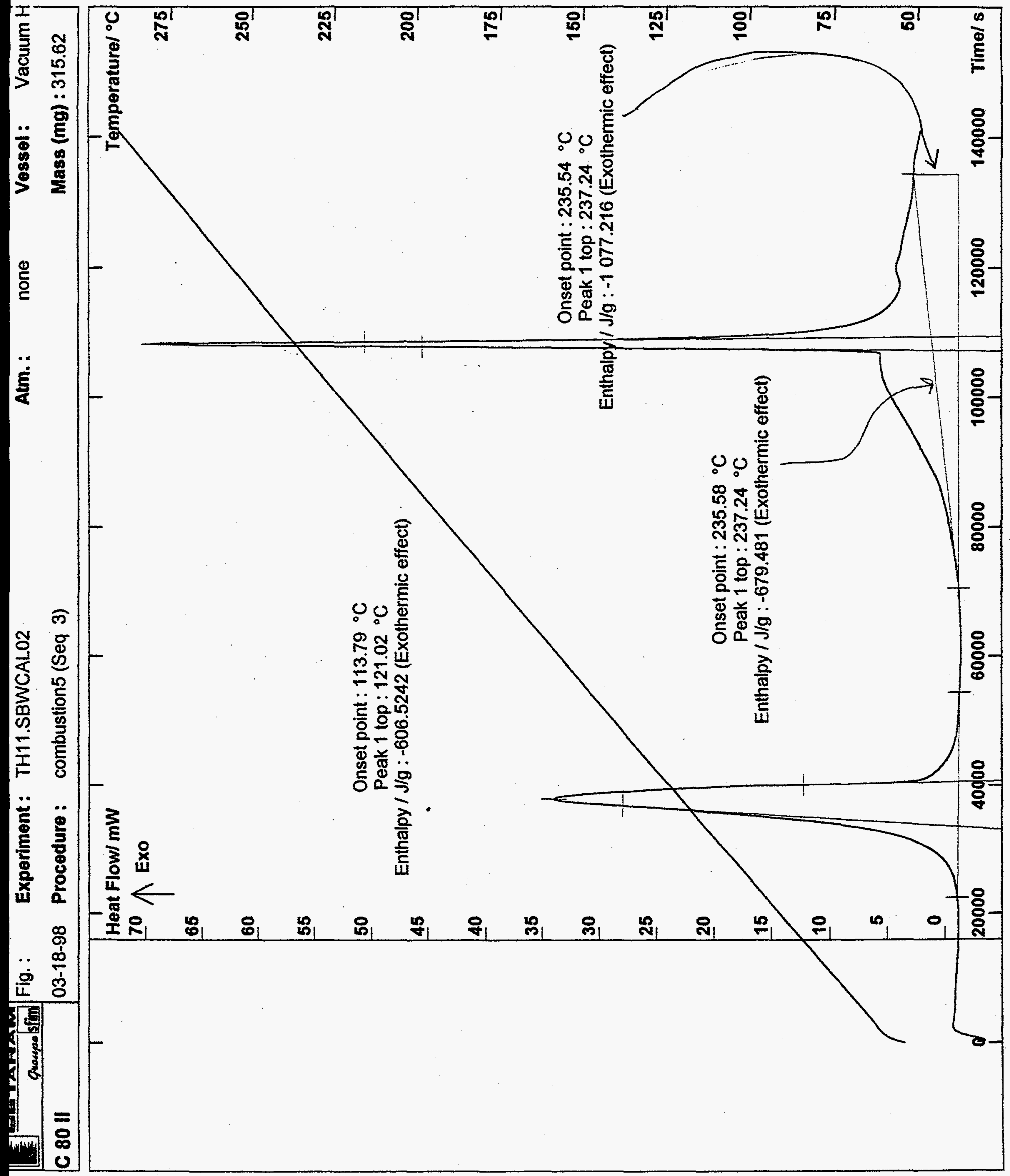




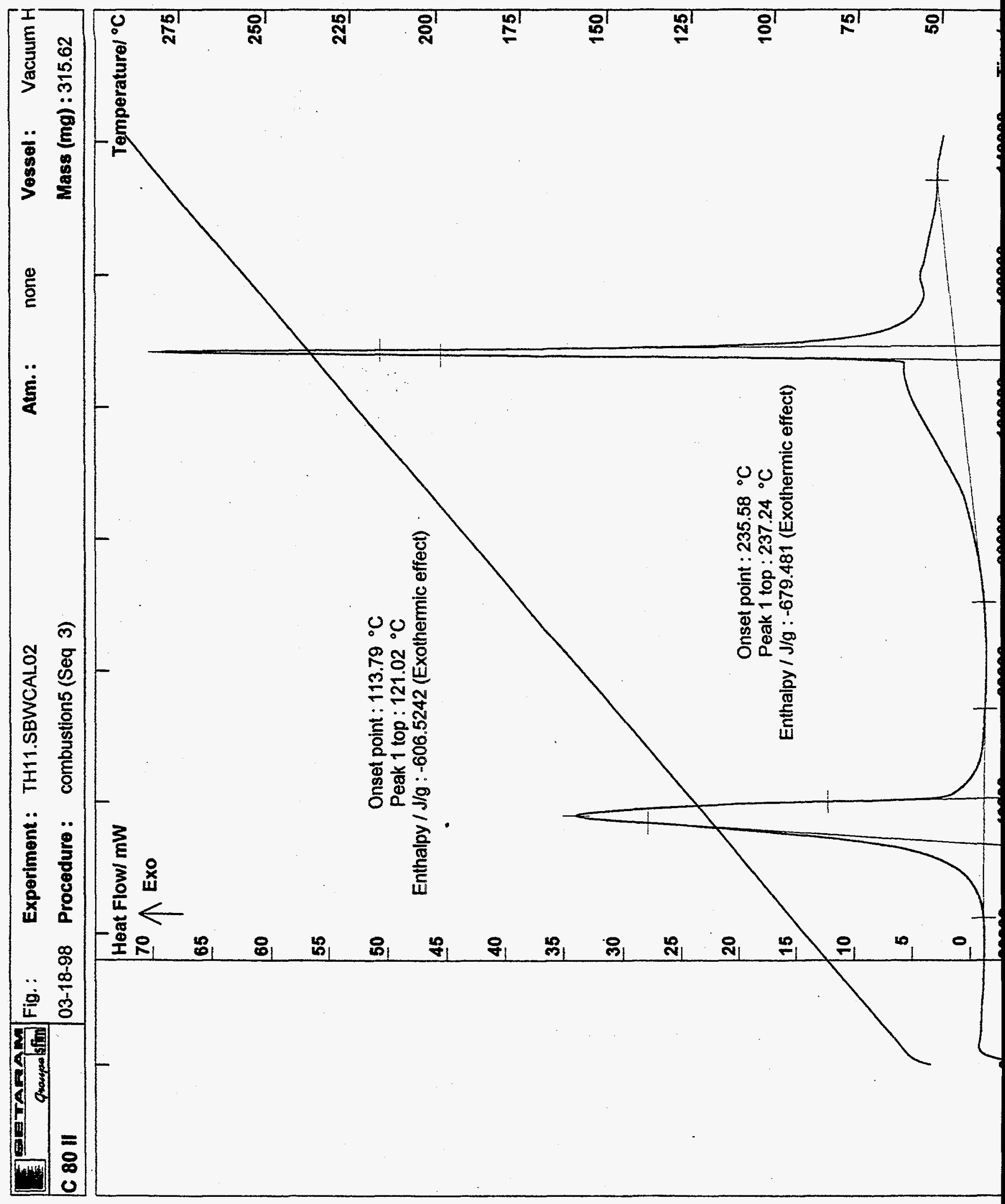


Standard Collection

PARAMETERS

Device: C 8011 -No option
User:
Charlie
Group: Todd Hart

Date and Hour: $18 / 03 / 1998-11: 58: 44$

Security $\mathrm{T}^{\circ}$ (Sample) : $300.00^{\circ} \mathrm{C}$

Vessel : Vacuum HP Hast

Atm. : none

HF1 Attenuation : $\times 10(\mathrm{HF}=+/-20 \mathrm{mV}$ max $)$
Collection on sample

Stop mode : Pause

Masse : $315.62 \mathrm{mg}$

Masse Molaire : $0.0 \mathrm{~g} / \mathrm{mol}$

\section{Furnace 1}

$P \quad=8$

$1=60$

D $=800$

$\mathrm{U}=0$

Security $\mathrm{T}^{\circ}: 300.00^{\circ} \mathrm{C}$

Temperature correction coefficients : $C=B O+B 1^{\star} T+B 2^{\star} R+B 3^{\star} R^{\wedge} 2\left(T\right.$ and $C$ in ${ }^{\circ} C, R$ in $\left.K / m i n\right)$

$\mathrm{BO}=0.0 \mathrm{E}+00$

$B 1=0.0 E+00$

$B 2=0.0 E+00$

$B 3=0.0 E+00$

Sensitivity coefficients $n^{\circ} 1: S=A 0+A 1^{\star} T+A 2^{\star} T^{\wedge} 2+A 3^{\star} T^{\wedge} 3+A 4^{\star} T^{\wedge} 4\left(T=t^{\circ}\right.$ in ${ }^{\circ} \mathrm{C}$, S in $\left.\mu V / m W\right)$

$A O=3.202 E+01 \quad A 1=4.116 E-03 \quad A 2=-2.382 E-04 \quad A 3=6.508 E-07 \quad A 4=-7.609 E-10$ 
Standard Collection

SEQUENCES

Device: $\quad$ C 80 II - No option

User: Charlie Group: Todd Hart

Date and Hour: $18 / 03 / 1998-11: 58: 44$

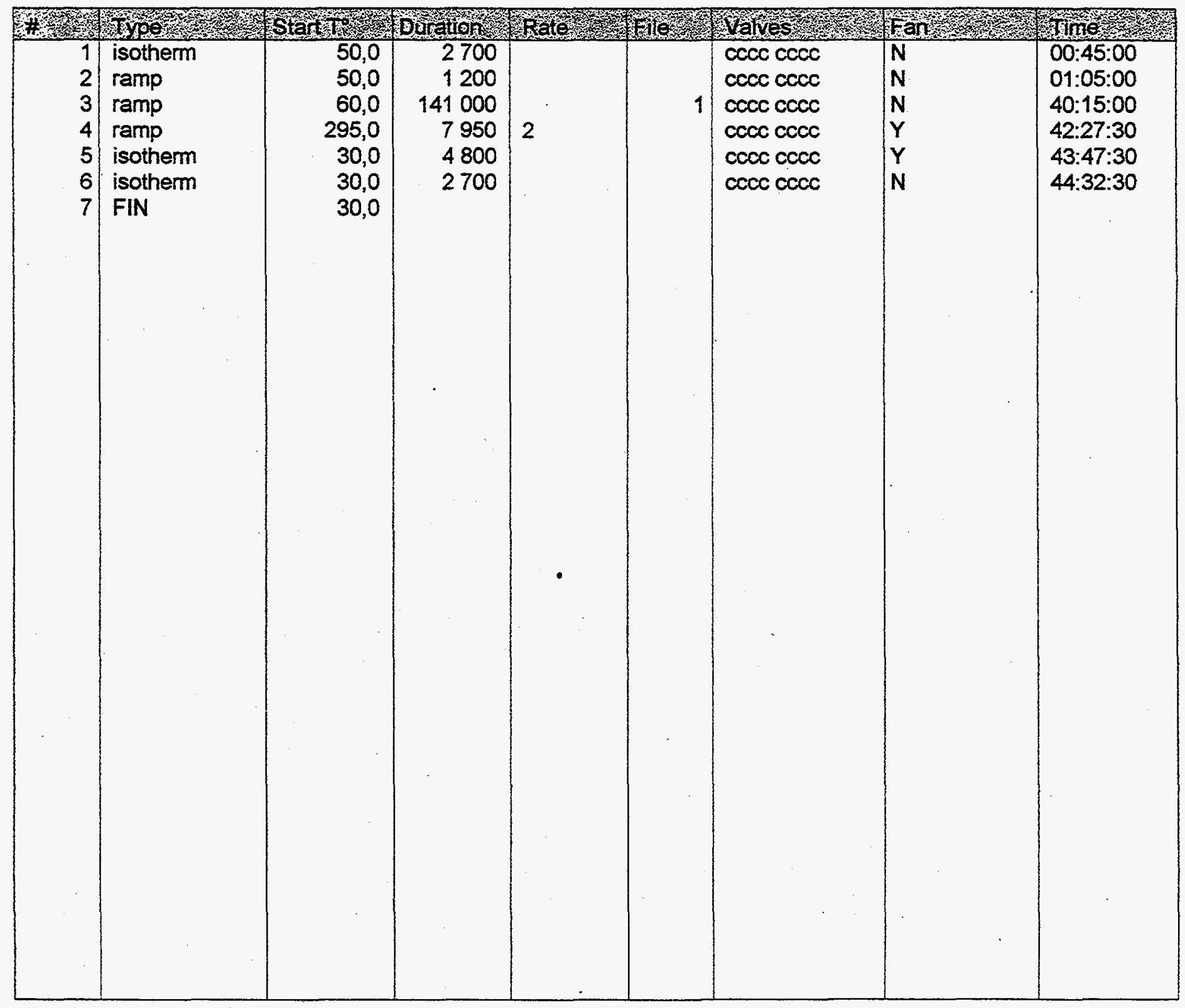


Reaction Calorimetry Test Run $2 b$

(Run Conditions Provided in Table 5.3) 


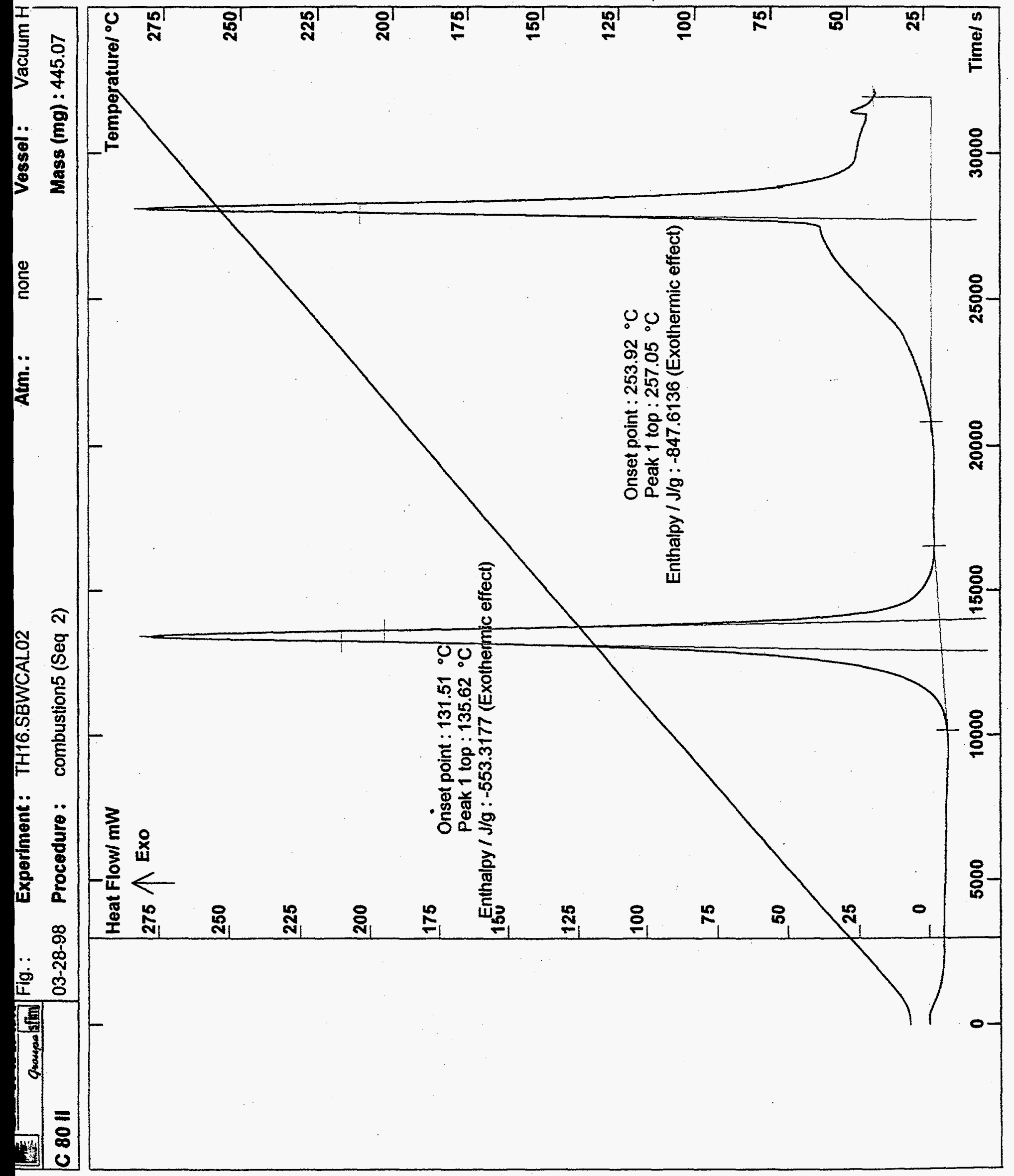


Standard Collection

PARAMETERS

Device: $\quad$ C 80 II-No option

User: Charlie Group: Todd Hart

Date and Hour: 28/03/1998-13:04:15
Security $\mathrm{T}^{\circ}$ (Sample) : $305.00^{\circ} \mathrm{C}$

Vessel : Vacuum HP Hast

Atm. : none

HF1 Attenuation : $x 10(\mathrm{HF}=+1-20 \mathrm{mV}$ max $)$
Collection on sample

Stop mode : Pause

Masse : $445.07 \mathrm{mg}$

Masse Molaire : $0.0 \mathrm{~g} / \mathrm{mol}$
Furnace 1
$P=8$
$1=60$
D $=800$
$\mathrm{U}=0$
Security $\mathrm{T}^{\circ}: 305.00^{\circ} \mathrm{C}$

Temperature correction coefficients : $C=B O+B 1^{\star} T+B 2^{\star} R+B 3^{\star} R^{\wedge} 2\left(T\right.$ and $C$ in ${ }^{\circ} C, R$ in $\left.K / m i n\right)$

$B O=0.0 E+00 \quad B 1=0.0 E+00 \quad B 2=0.0 E+00 \quad B 3=0.0 E+00$

Sensitivity coefficients $n^{\circ} 1: S=A 0+A 1^{\star} T+A 2^{\star} T^{\wedge} 2+A 3^{\star} T^{\wedge} 3+A 4^{\star} T^{\wedge} 4\left(T=t^{\circ}\right.$ in ${ }^{\circ} \mathrm{C}, S$ in $\left.\mu V / m W\right)$

$A O=3.202 E+01 \quad A 1=4.116 E-03 . \quad A 2=-2.382 E-04 \quad A 3=6.508 E-07 \quad A 4=-7.609 E-10$ 


\section{TH16.SBWCAL02}

Standard Collection

SEQUENCES

Device: $\quad$ C 80 II - No option

User: Charlie Group: Todd Hart

Date and Hour: 28/03/1998-13:04:15

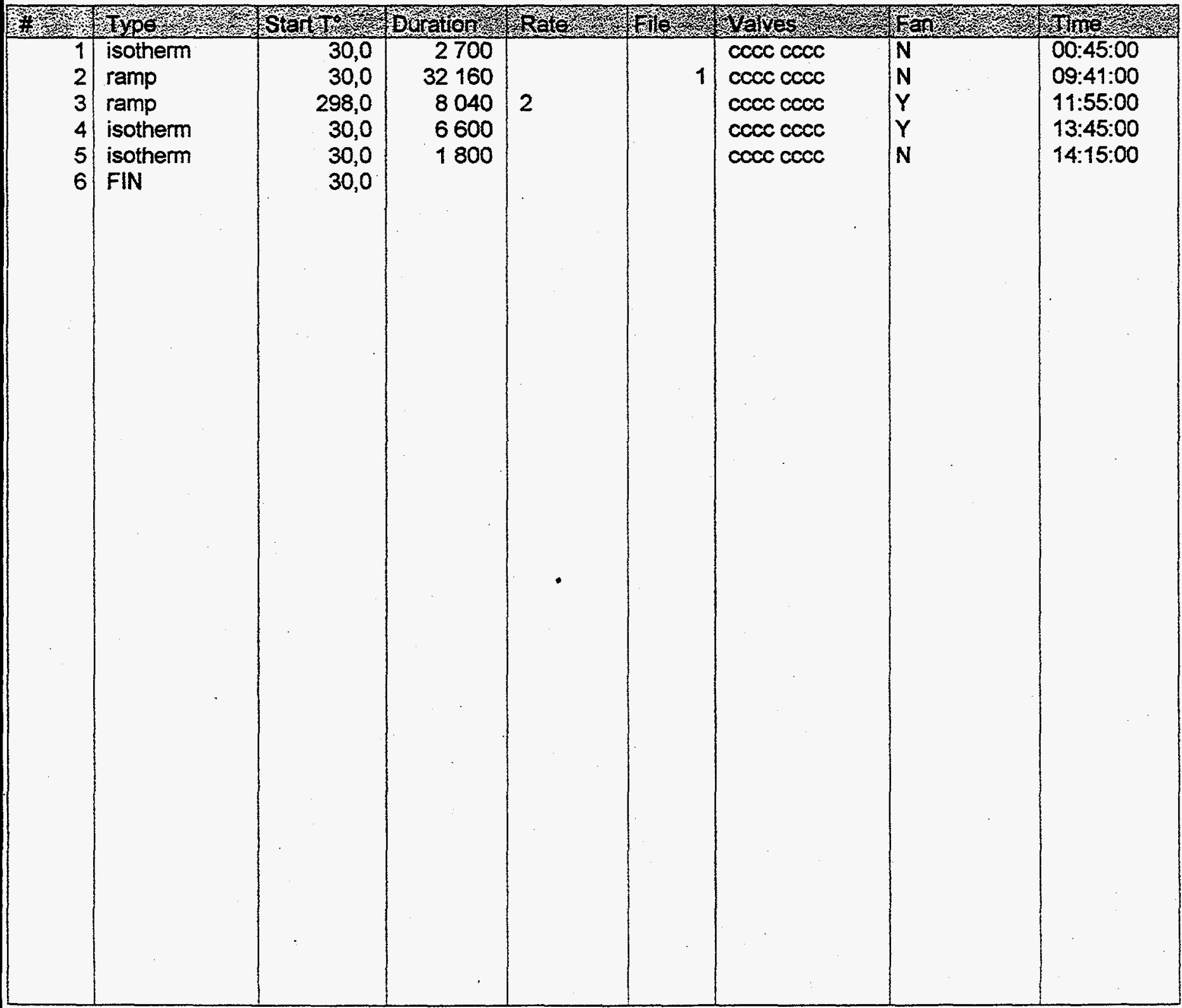


Reaction Calorimetry Test Run 3

(Run Conditions Provided in Table 5.3) 


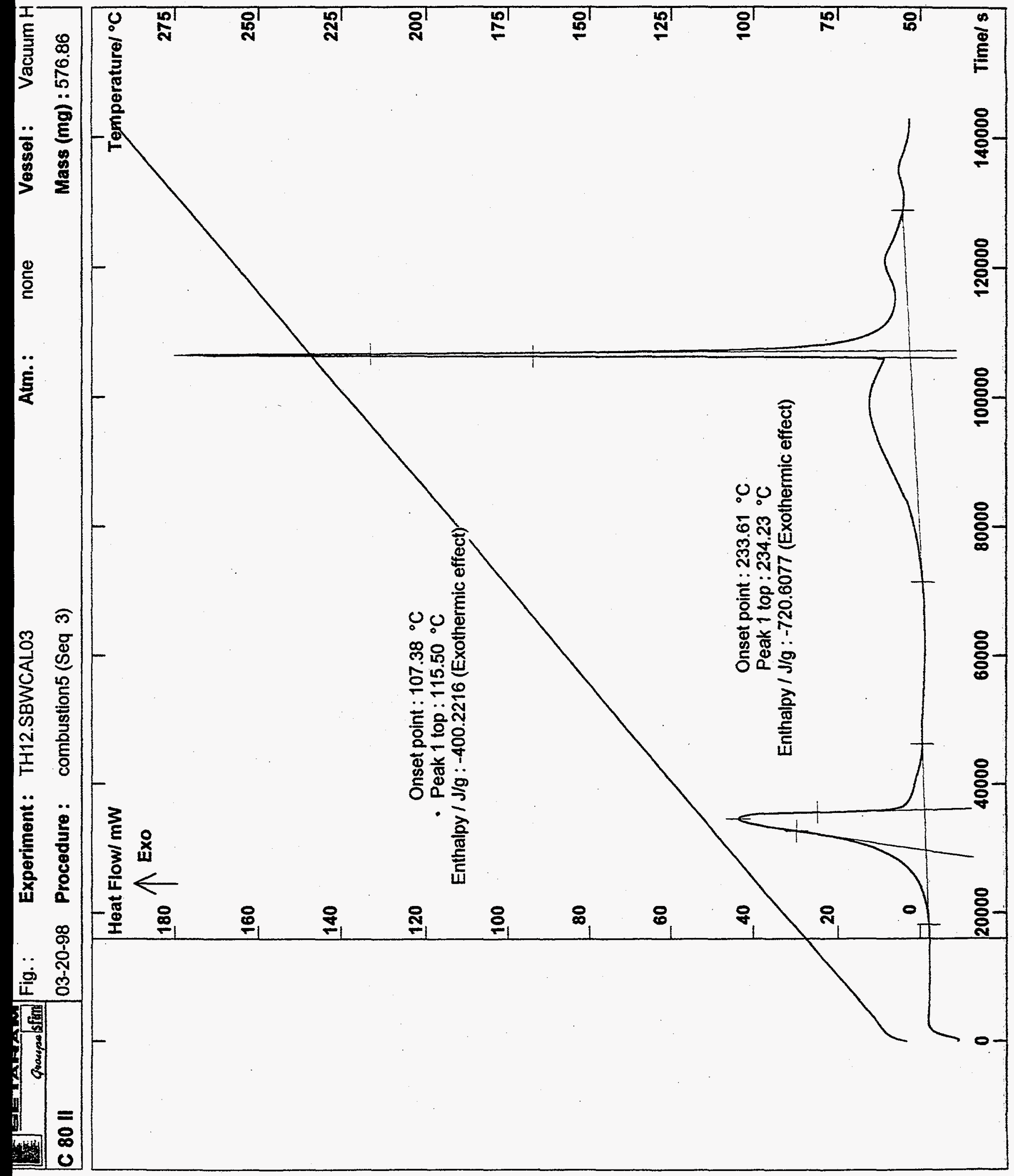




\section{TH12.SBWCAL03}

Standard Collection

PARAMETERS

Device: $\quad$ C $8011-$ No option

User: Charlie Group: Todd Hart

Date and Hour: 20/03/1998-14:30:49

Security $\mathrm{T}^{\circ}$ (Sample) : $305.00^{\circ} \mathrm{C}$

Vessel : Vacuum HP Hast

Atm. : none

HF1 Attenuation : $\times 10(\mathrm{HF}=+1-20 \mathrm{mV}$ max $)$
Collection on sample

Stop mode : Pause

Masse : $576.86 \mathrm{mg}$

Masse Molaire: $0.0 \mathrm{~g} / \mathrm{mol}$

\section{Furnace 1}

$P \quad=8$

$1=60$

$D=800$

$U=0$

Security $\mathrm{T}^{\circ}: 305.00^{\circ} \mathrm{C}$

Temperature correction coefficients : $C=B O+B 1^{\star} T+B 2^{\star} R+B 3^{\star} R^{\wedge} 2\left(T\right.$ and $C$ in ${ }^{\circ} C, R$ in $\left.K / m i n\right)$

$B O=0.0 E+00$

$B 1=0.0 E+00$

$B 2=0.0 E+00$

$B 3=0.0 E+00$

Sensitivity coefficients $n^{\circ} 1: S=A O+A 1^{\star} T+A 2^{*} T^{\wedge} 2+A 3^{*} T^{\wedge} 3+A 4^{*} T^{\wedge} 4\left(T=t^{\circ}\right.$ in ${ }^{\circ} \mathrm{C}$, S in $\left.\mu V / m W\right)$ $A O=3.202 E+01 \quad A 1=4.116 E-03 \quad A 2=-2.382 E-04 \quad A 3=6.508 E-07 \quad A 4=-7.609 E-10$ 
Standard Collection

SEQUENCES

Device: C 8011 - No option

User: Charlie Group: Todd Hart

Date and Hour: $20 / 03 / 1998-14: 30: 49$

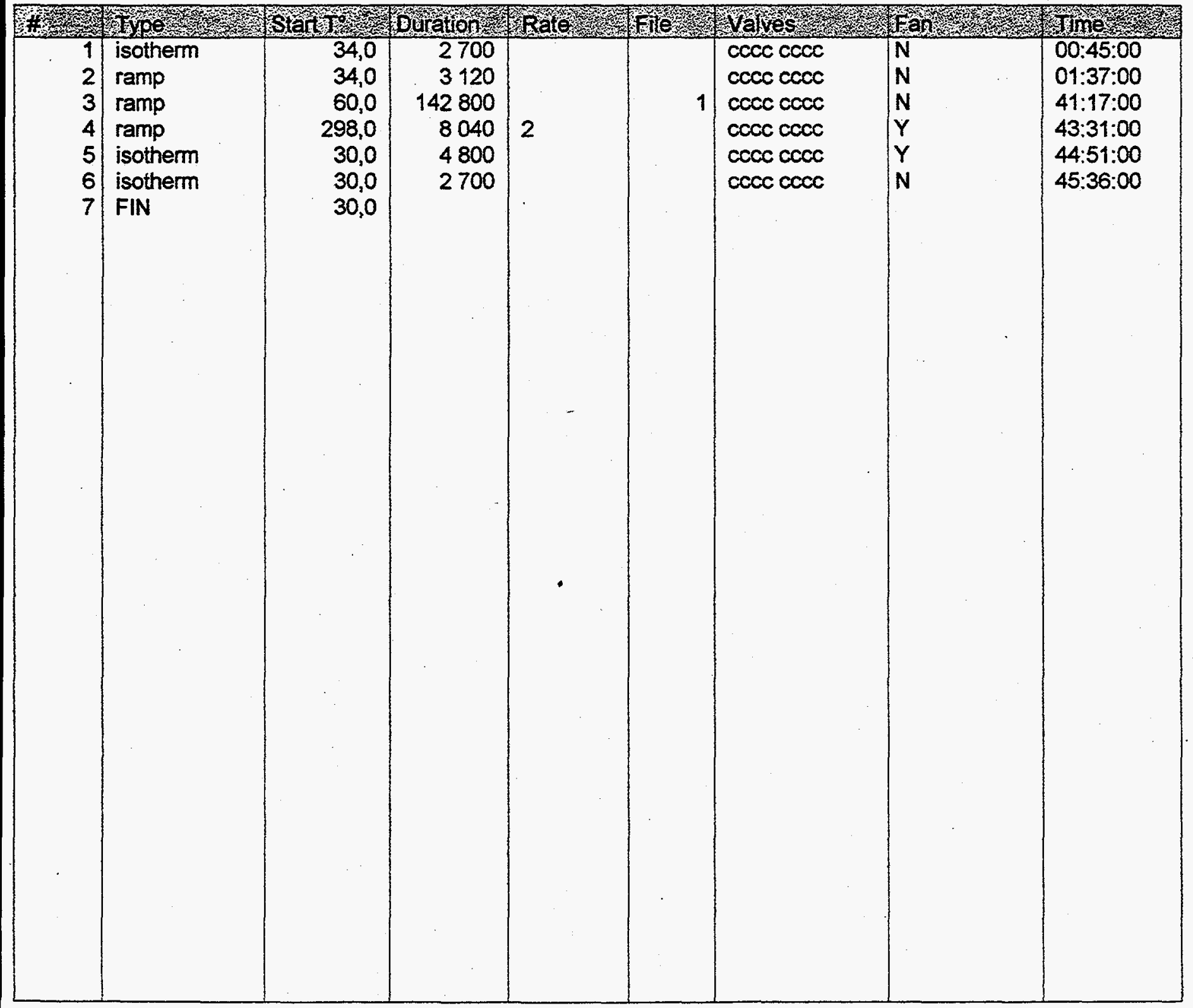


Reaction Calorimetry Test Run 4

(Run Conditions Provided in Table 5.3) 


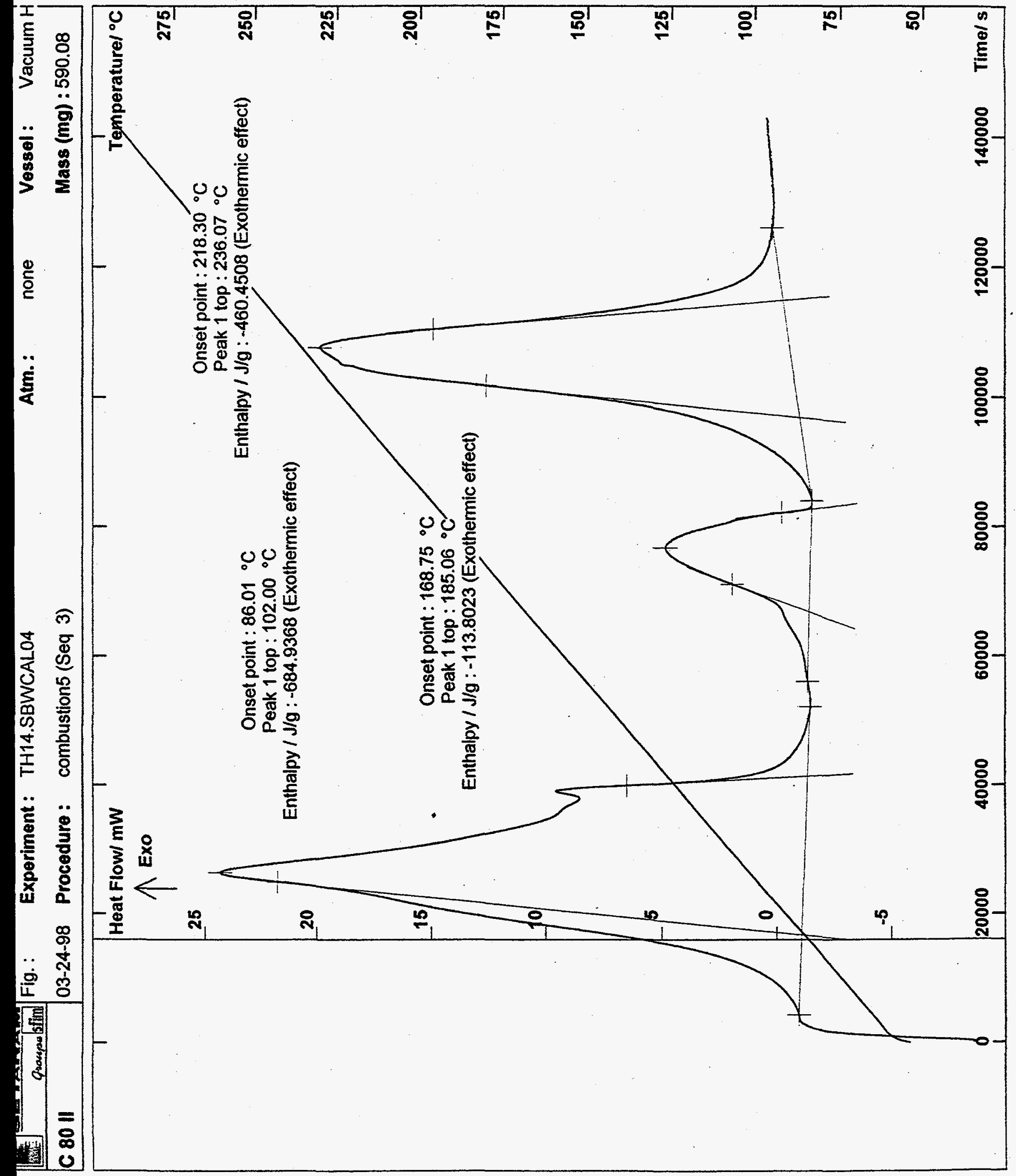




\section{TH14.SBWCAL04}

Standard Collection

PARAMETERS

Device: $\quad$ C 8011 - No option

User: $\quad$ Charlie Group: Todd Hart

Date and Hour: 24/03/1998-19:00:34

Security $\mathrm{T}^{\circ}$ (Sample) : $305.00^{\circ} \mathrm{C}$

Vessel : Vacuum HP Hast

Atm. : none

HF1 Attenuation : $x 10(\mathrm{HF}=+1-20 \mathrm{mV}$ max $)$
Collection on sample

Stop mode : Pause

Masse : $590.08 \mathrm{mg}$

Masse Molaire : $0.0 \mathrm{~g} / \mathrm{mol}$

\section{Fumace 1 \\ $P=8$ \\ $1=60$ \\ $\mathrm{D}=800$ \\ $U=0$}

Security $\mathrm{T}^{\circ}: 305.00^{\circ} \mathrm{C}$

Temperature correction coefficients : $C=B 0+B 1^{\star} T+B 2^{\star} R+B 3^{\star} R^{\wedge} 2\left(T\right.$ and $C$ in ${ }^{\circ} C, R$ in $\left.K / m i n\right)$

$B D=0.0 E+00$

$B 1=0.0 E+00$

$B 2=0.0 E+00$

$B 3=0.0 E+00$

Sensitivity coefficients $n^{\circ} 1: S=A 0+A 1^{\star} T+A 2^{\star} T^{\wedge} 2+A 3^{\star} T^{\wedge} 3+A 4^{\star} T^{\wedge} 4\left(T=t^{\circ}\right.$ in ${ }^{\circ} C$, s in $\left.\mu V / m W\right)$
$A O=3.202 E+01$
$\mathrm{A} 1=4.116 \mathrm{E}-03$
$A 2=-2.382 E-04$
$\mathrm{A} 3=6.508 \mathrm{E}-07$
$A 4=-7.609 E-10$ 


\section{TH14.SBWCAL04}

Standard Collection

SEQUENCES

Device: C 80 ll-No option

User: Charlie Group: Todd Hart

Date and Hour: $24 / 03 / 1998-19: 00: 34$

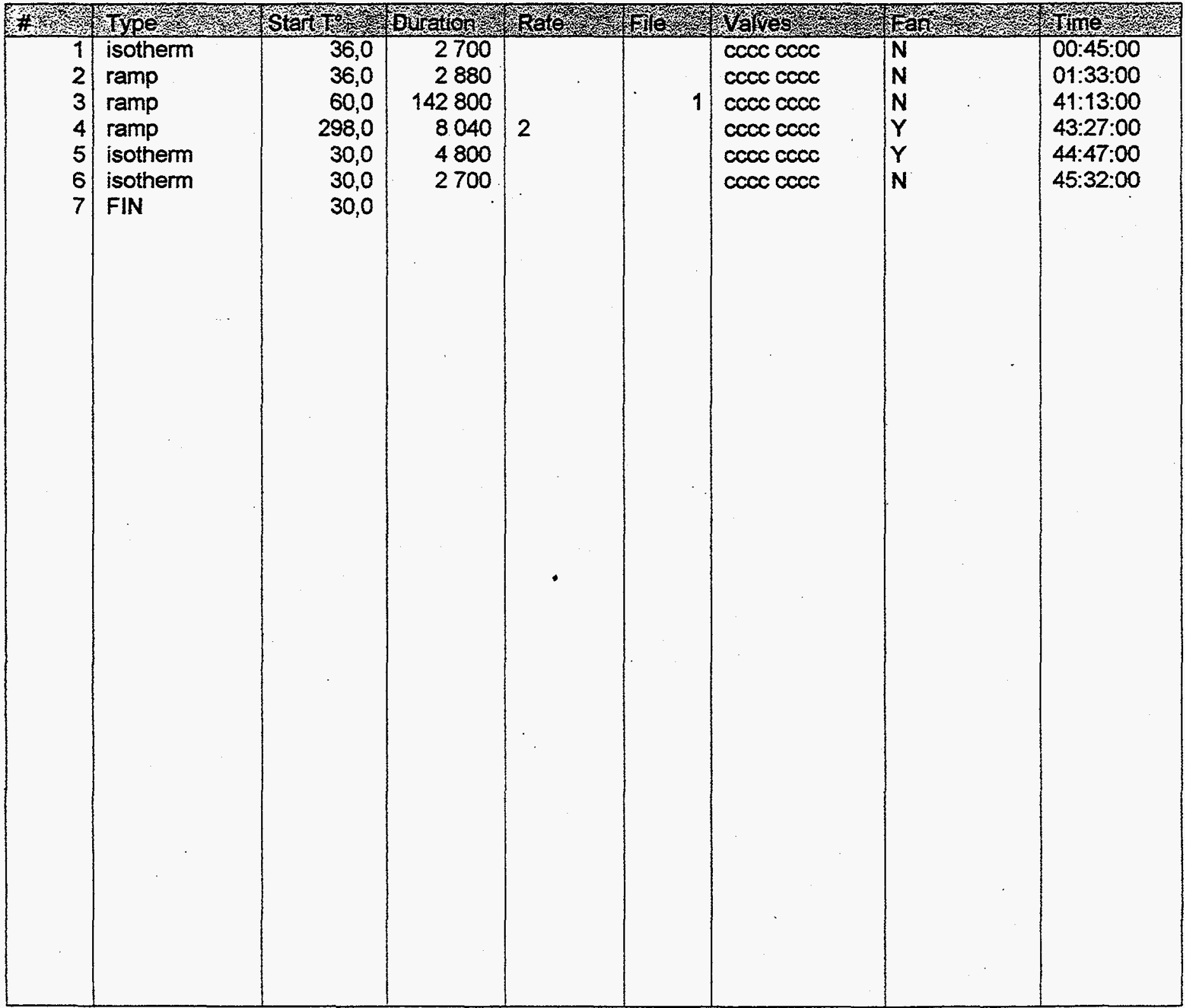


Reaction Calorimetry Test Run 5a

(Run Conditions Provided in Table 5.3) 


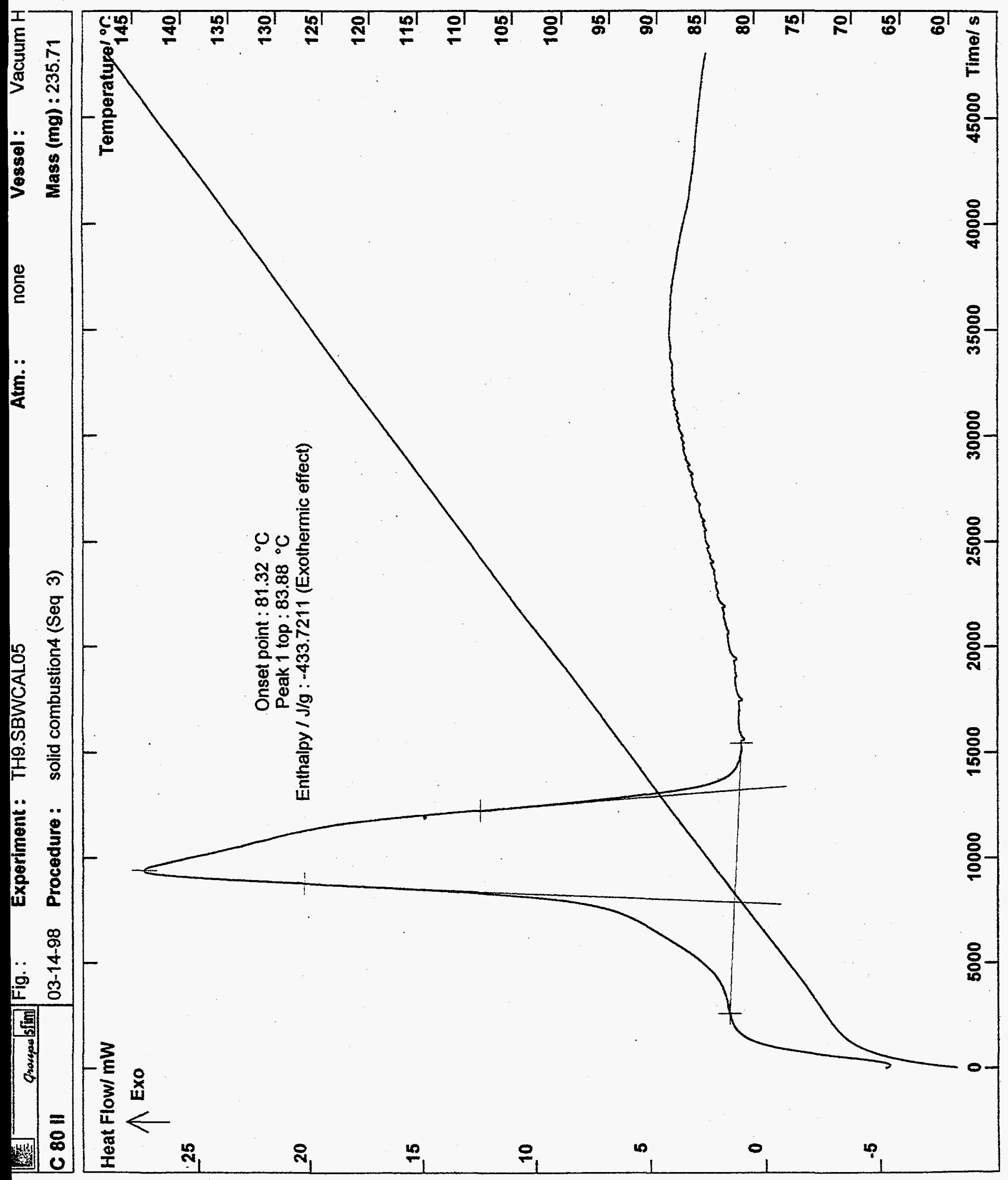




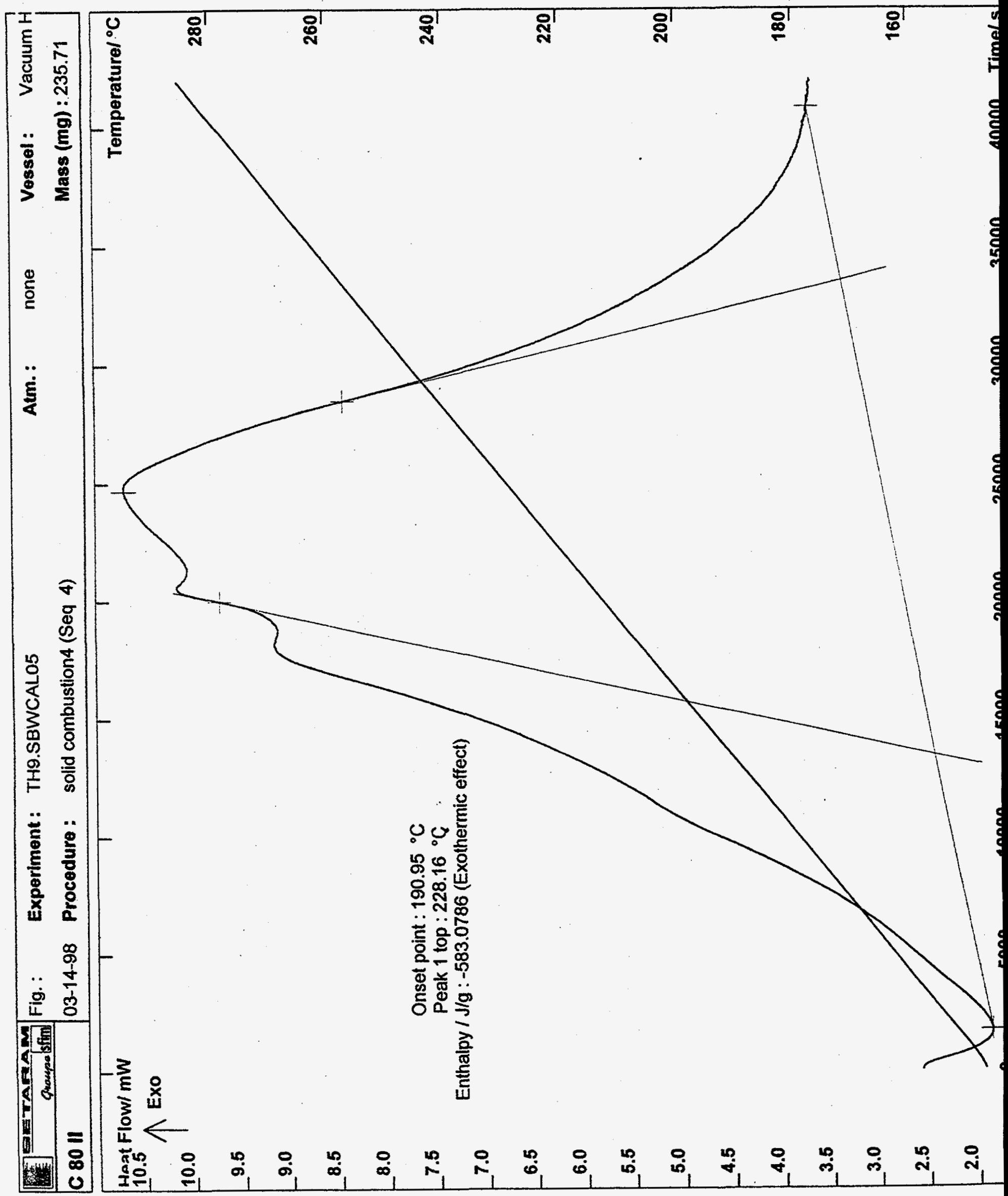


Standard Collection

SEQUENCES

Device: $\quad$ C 8011 - No option

User: Charlie $\quad$ Group: Todd Hart

Date and Hour: $14 / 03 / 1998-13: 52: 20$

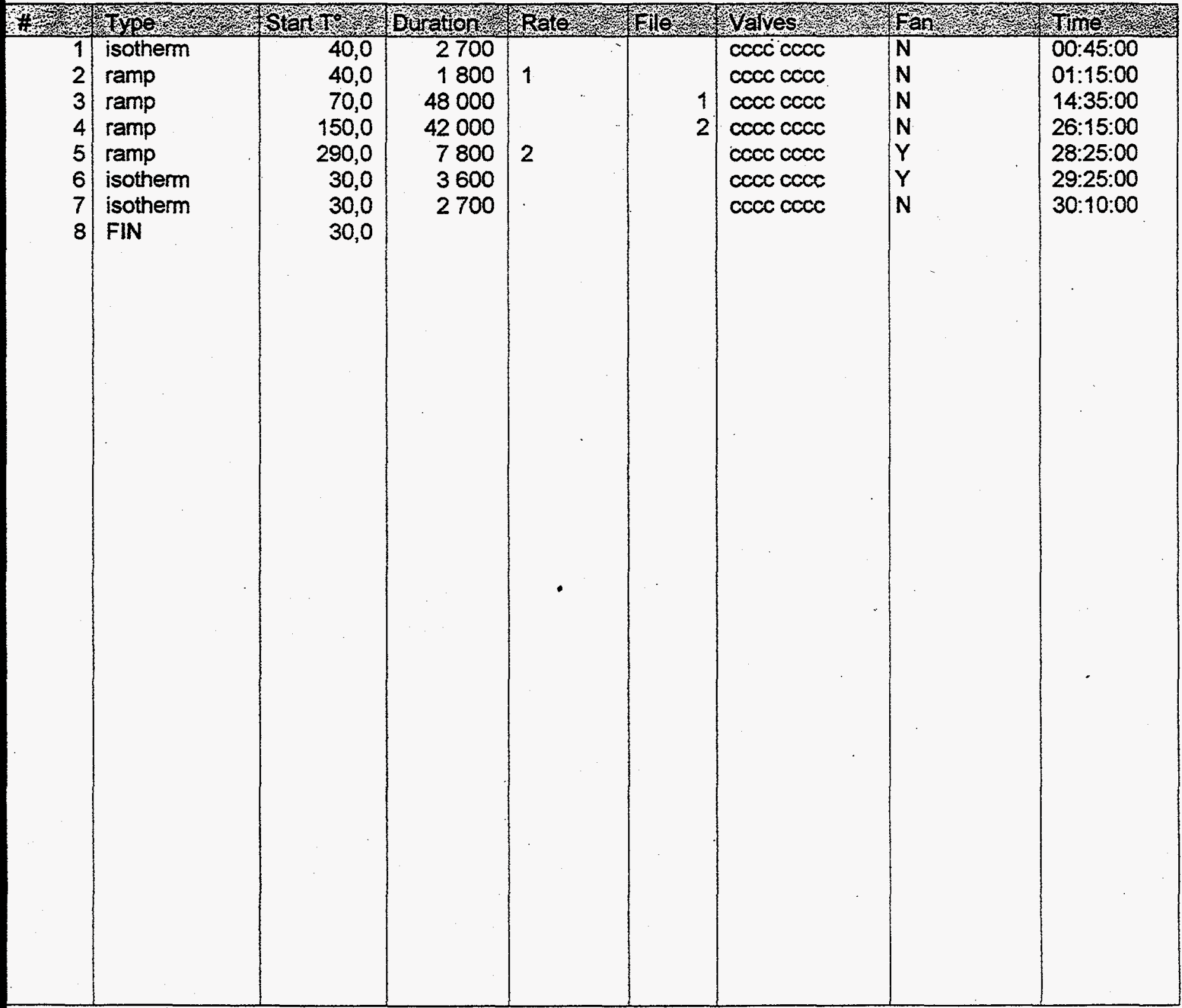


Standard Collection

PARAMETERS

Device: $\quad C 8011$-No option

User: Charlie Group: Todd Hart
Security $\mathrm{T}^{\circ}$ (Sample) : $300.00^{\circ} \mathrm{C}$

Vessel : Vacuum HP Hast

Atm. : none

HF1 Attenuation : $x 10(\mathrm{HF}=+1-20 \mathrm{mV}$ max $)$
Collection on sample

Stop mode : Pause

Masse : $235.71 \mathrm{mg}$

Masse Molaire : $0.0 \mathrm{~g} / \mathrm{mol}$

Furnace 1

$P=8$

$1=60$

$D=800$

$U=0$

Security $\mathrm{T}^{\circ}: 300.00^{\circ} \mathrm{C}$

Temperature correction coefficients : $C=B O+B 1^{\star} T+B 2^{\star} R+B 3^{\star} R^{\wedge} 2\left(T\right.$ and $C$ in ${ }^{\circ} C, R$ in $\left.K / m i n\right)$
$B O=0.0 E+00$
$B 1=0.0 E+00$
$B 2=0.0 E+00$
$B 3=0.0 E+00$

Sensitivity coefficients $n^{\circ} 1: S=A 0+A 1^{\star} T+A 2^{\star *} T^{\wedge} 2+A 3^{\star} T^{\wedge} 3+A 4^{\star} T^{\wedge} 4\left(T=t^{\circ}\right.$ in ${ }^{\circ} \mathrm{C}, S$ in $\left.\mu V / m W\right)$

$A O=3.202 E+01$

$\mathrm{A} 1=4.116 \mathrm{E}-03$

$A 2=-2.382 E-04$

$A 3=6.508 E-07$

$A 4=-7.609 E-10$ 
Reaction Calorimetry Test Run 5b

(Run Conditions Provided in Table 5.3) 


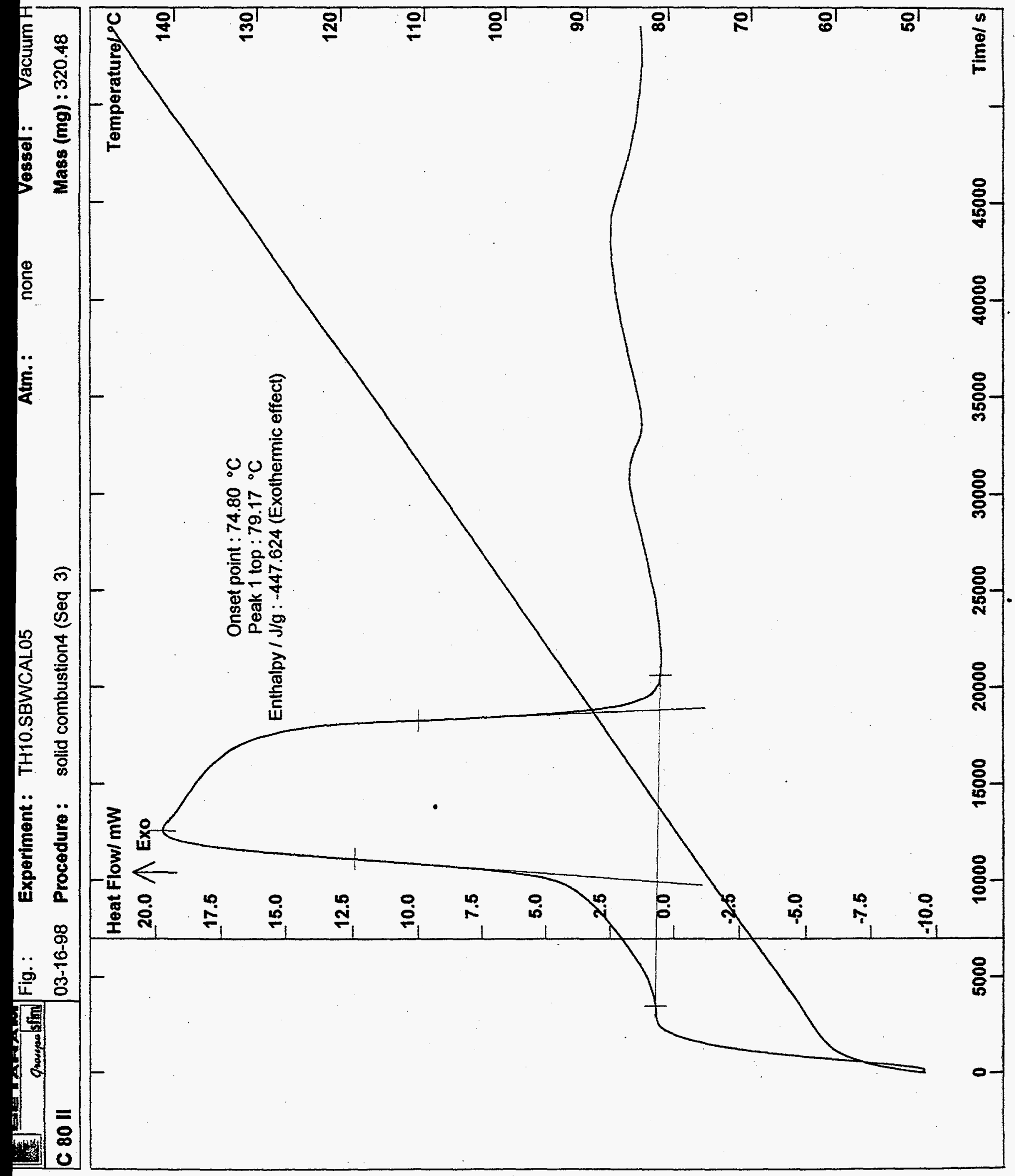




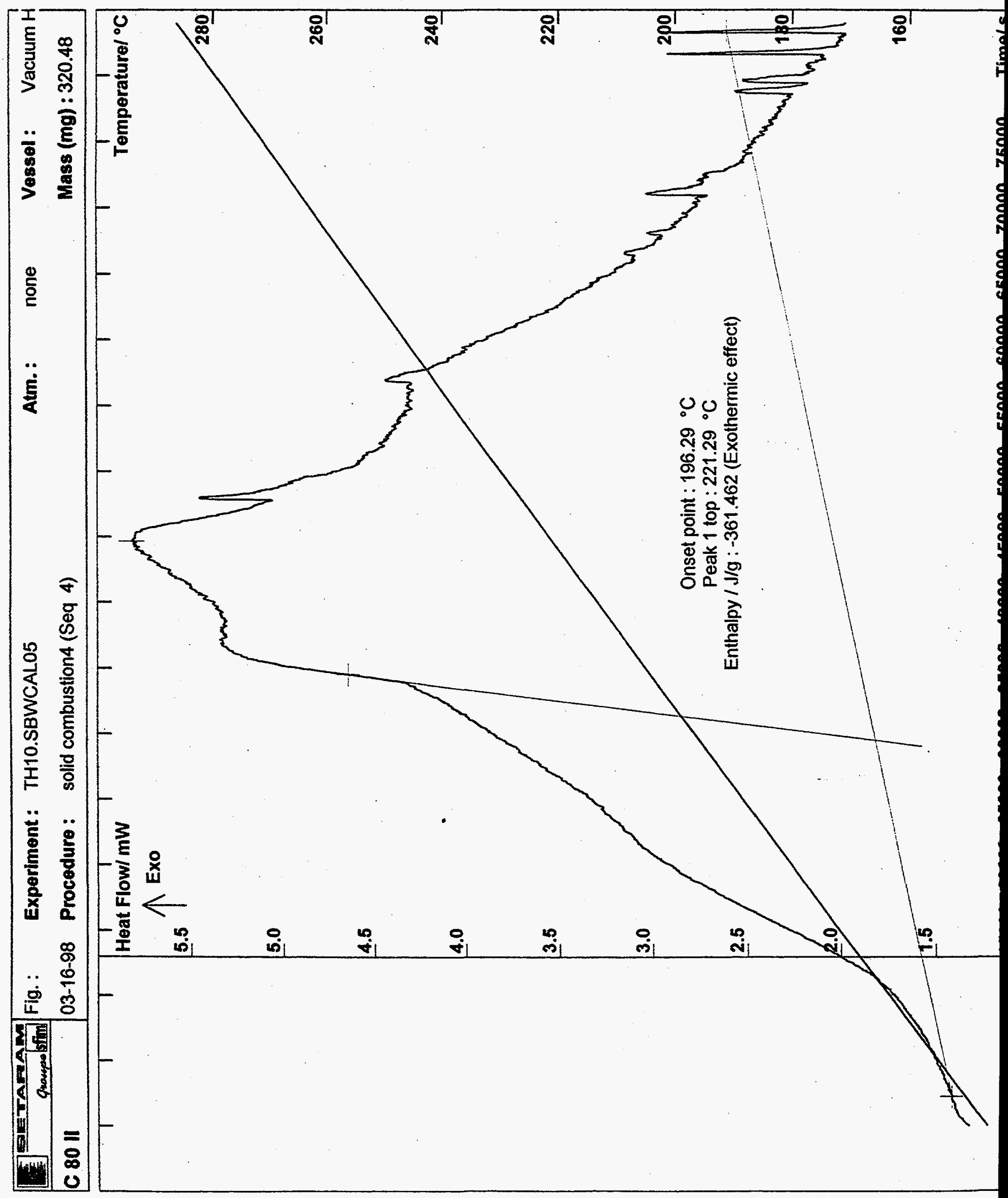




\section{TH10.SBWCAL05}

tandard Collection

SEQUENCES

Device: $\quad$ C 80 II - No option

User: Charlie Group: Todd Hart

Date and Hour: 16/03/1998-14:47:31

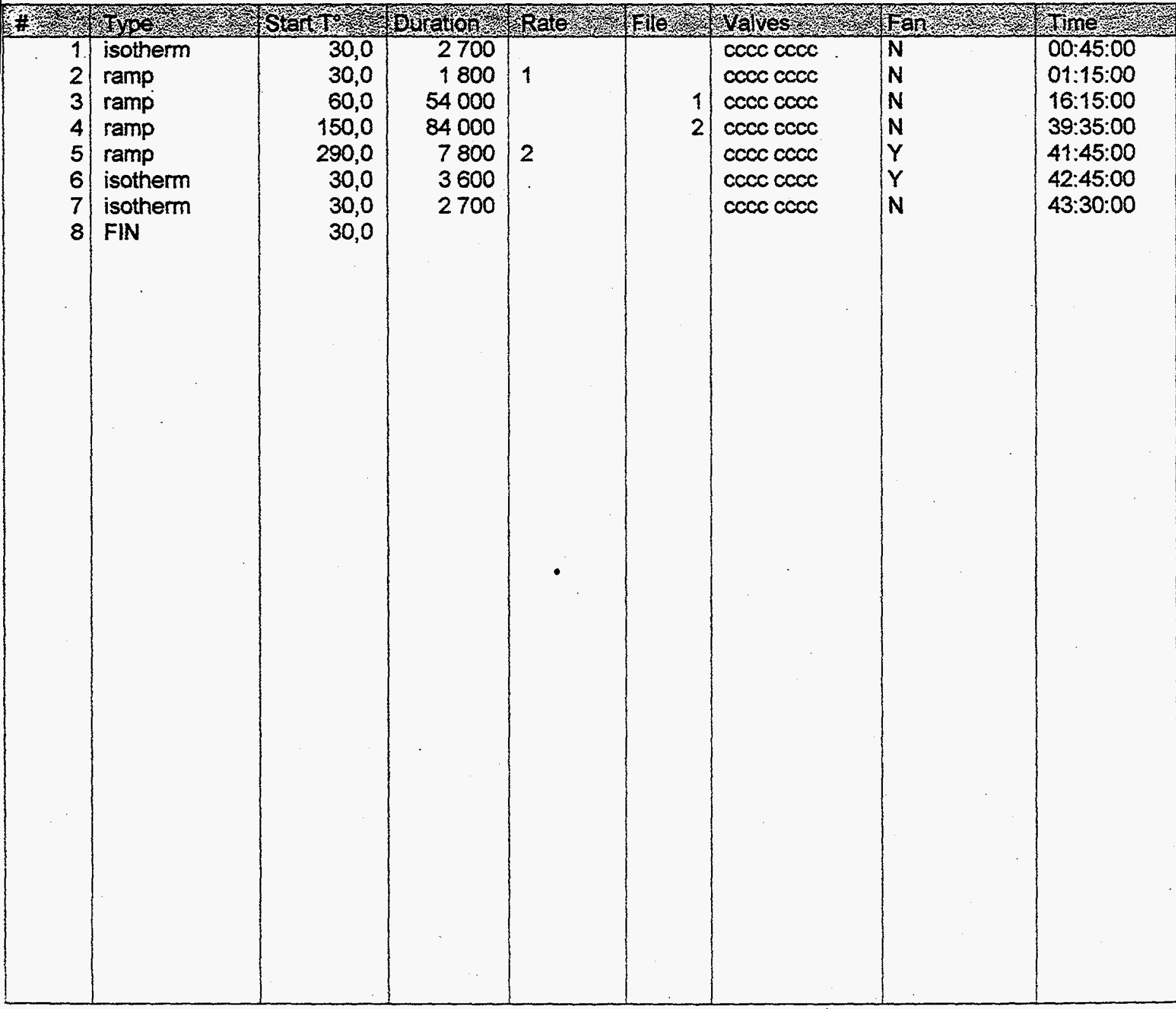


Standard Collection

PARAMETERS

Device:- C 80 II-No option

User: Charlie Group: Todd Hart

Date and Hour: $16 / 03 / 1998-14: 47: 31$

Security $\mathrm{T}^{\circ}$ (Sample) : $300.00^{\circ} \mathrm{C} \quad$ Collection on sample Stop mode : Pause

Vessel : Vacuum HP Hast $\quad$ Masse : $320.48 \mathrm{mg}$
Atm. : none
Masse Molaire : $0.0 \mathrm{~g} / \mathrm{mol}$

HF1 Attenuation : $x 10$ (HF $=+1-20 \mathrm{mV}$ max)

\section{Fumace 1 \\ $P=8$ \\ $1=60$ \\ $D=800$ \\ $U=0$}

Security $\mathrm{T}^{\circ}: 300.00^{\circ} \mathrm{C}$

Temperature correction coefficients : $C=B O+B 1^{\star} T+B 2^{\star} R+B 3^{\star} R^{\wedge} 2\left(T\right.$ and $C$ in ${ }^{\circ} C, R$ in $\left.K / m i n\right)$

$B 0=0.0 E+00 \quad B 1=0.0 E+00 \quad B 2=0.0 E+00 \quad B 3=0.0 E+\infty 0$

Sensitivity coefficients $n^{\circ} 1: S=A 0+A 1^{\star} T+A 2^{*} T^{\wedge} 2+A 3^{\star} T^{\wedge} 3+A 4^{\star} T^{\wedge} 4\left(T=t^{\circ}\right.$ in ${ }^{\circ} \mathrm{C}$, S in $\left.\mu V / m W\right)$

$A O=3.202 E+01 \quad A 1=4.116 E-03 \quad A 2=-2.382 E-04 \quad A 3=6.508 E-07 \quad A 4=-7.609 E-10$ 
Reaction Calorimetry Test Run 6

(Run Conditions Provided in Table 5.3) 


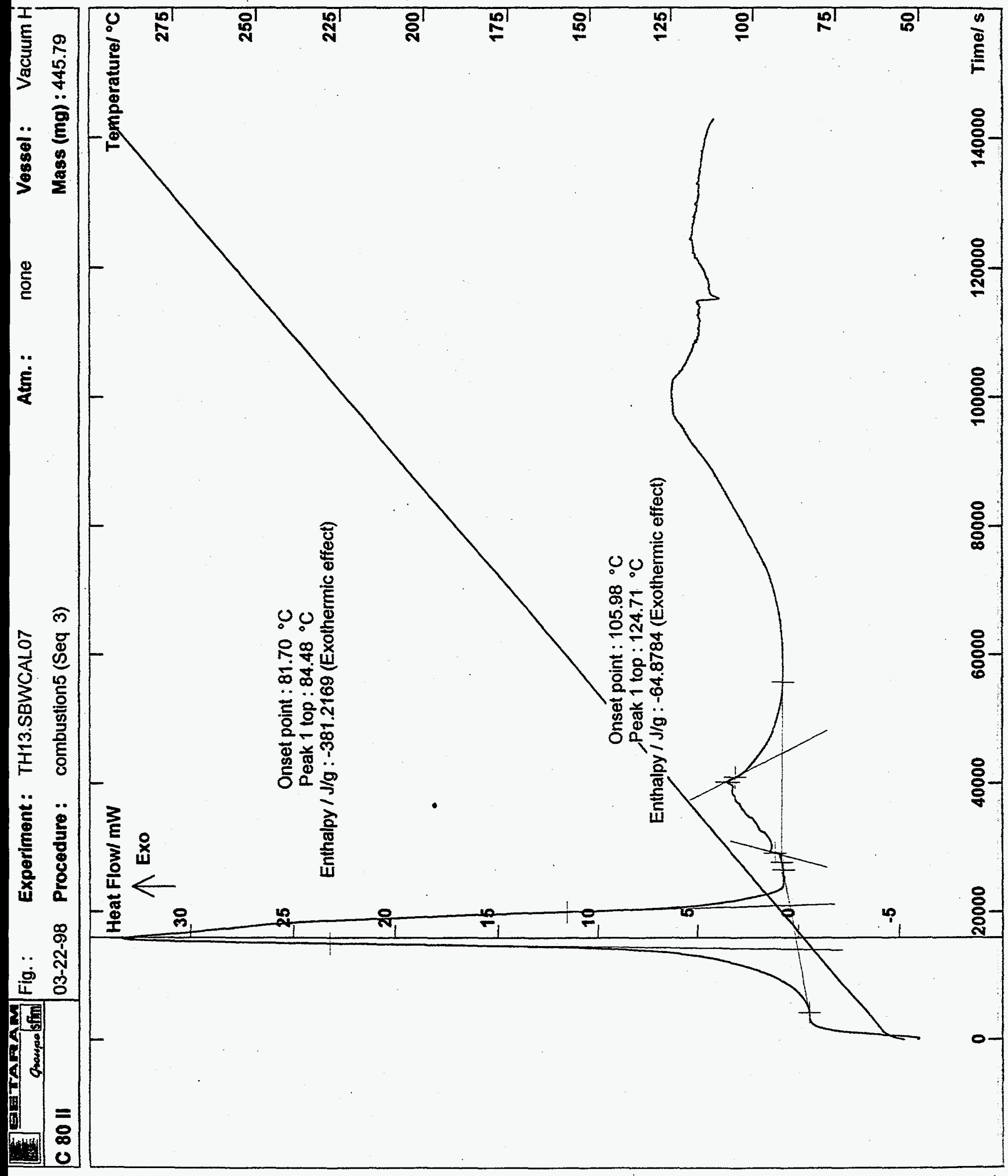




\section{TH13.SBWCAL07}

Standard Collection

PARAMETERS

Device: $\quad$ C 8011 - No option

User: Charlie Group: Todd Hart

Date and Hour: $22 / 03 / 1998-16: 27: 28$

Security $\mathrm{T}^{\circ}$ (Sample) : $305.00^{\circ} \mathrm{C}$

Vessel : Vacuum HP Hast

Atm. : none

HF1 Attenuation : $x 10$ (HF $=+l-20 \mathrm{mV}$ max $)$
Collection on sample

Stop mode : Pause

Masse : $445.79 \mathrm{mg}$

Masse Molaire : $0.0 \mathrm{~g} / \mathrm{mol}$

\section{Fumace 1}

$P \quad=8$

$1=60$

$D \quad=800$

$U=0$

Seciurity $\mathrm{T}^{\circ}: 305.00^{\circ} \mathrm{C}$

Temperature correction coefficients : $C=B O+B 1^{\star} T+B 2^{\star} R+B 3^{\star} R^{\wedge} 2\left(T\right.$ and $C$ in ${ }^{\circ} C, R$ in $\left.K / m i n\right)$

$B O=0.0 E+00 \quad B 1=0.0 E+\infty 0 \quad B 2=0.0 E+\infty 0 \quad B 3=0.0 E+00$

Sensitivity coefficients $n^{\circ} 1: S=A 0+A 1^{\star} T+A 2^{\star} T^{\wedge} 2+A 3^{*} T^{\wedge} 3+A 4^{\star} T^{\wedge} 4\left(T=t^{\circ}\right.$ in ${ }^{\circ} \mathrm{C}$, S in $\left.\mu V / m W\right)$

$A O=3.202 E+01$

$\mathrm{A} \uparrow=4.116 \mathrm{E}-03$

$A 2=-2.382 E-04$

$\mathrm{A} 3=6.508 \mathrm{E}-07$

$A 4=-7.609 E-10$ 
Standard Collection

SEQUENCES

Device: C 80 II- No option

User: Charlie Group: Todd Hart

Date and Hour: 22/03/1998-16:27:28

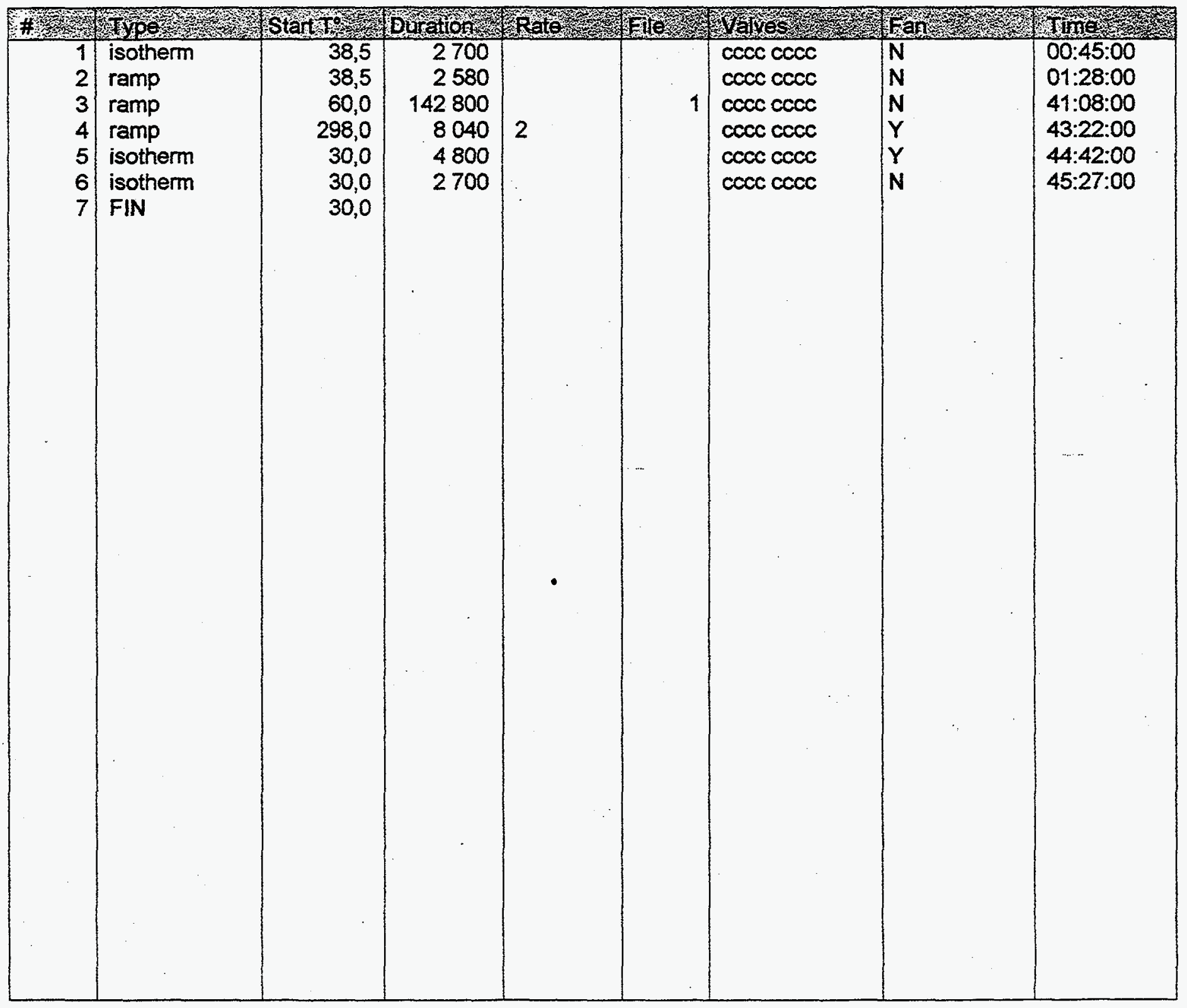

